Jubilee Volume (1946-2001) : pp. 169 - 288, December, 2001

ISSN 1516-8913 Printed in Brazil

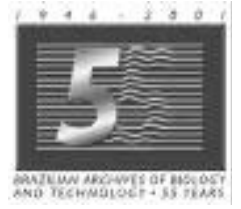

BRAZILIAN ARCHIVES OF BIOLOGY AND TECHNOLOGY

\title{
Breves Notícias Sobre a Geologia dos Estados do Paraná e Santa Catarina
}

\author{
Reinhard Maack \\ Instituto de Biologia e Pesquisas Tecnológicas
}

\begin{abstract}
The present short survey of the geology of the States of Paraná and Santa Catarina was written as a text to accompany sketches for the revision of the GEOLOGICAL MAP OF SOUTH AMERICA. It contains the results of geologic research up to the year 1947 in most concise form, without going into detail. As requested, the occurrence of useful minerals was not considered in the summary, and the list of bibliographical references has been condensed to the uttermost. Inasmuch as the author treated the Passa Dois Series in more detail, due to the reorganization of the Gondwana beds, the Archean and the Algonkian had to be reduced to the minimum. This was possible, since the innumerable details of the phenomena in the crystalline complex could not be represented in a geologic map of the given scale. The reorganization of the geologic constituents of Parana and Santa Catarina is summarized in Stratigraphic Table $n^{\circ} 2$, and is explained by the enclosed sketches.
\end{abstract}

Key Words: Geology; Gondwana beds; Archean; Algonkian; Crystalline complex; Passa Dois Series

\section{INTRODUÇÃO}

Os trabalhos geológicos recentemente realizados nos Estados do Paraná e Santa Catarina completam, de modo notável, as representações fundamentais destas regiões, publicadas por WHITE (1908) e por OLIVEIRA (1918; 1927). Relativamente à estratigrafia dos dois estados sulinos e à elucidação das linhas orográficas principais do Estado do Paraná e, ainda, sobre o reconhecimento da tectônica da Serra do Mar e da Serra Geral, foram conseguidos resultados particularmente importantes. Chama-se especialmente a atenção para a verificação dos sedimentos suprabasálticos, para a nova estratigrafia do devoniano no Estado do Paraná, como, também, para a elucidação da idade geológica das camadas glaciais da série Itararé e para os levantamentos cartográficos das principais falhas na Serra do Mar. Quanto à série Itajaí, em Santa Catarina, cuja idade geológica durante largo tempo fora discutida e que também hoje ainda não foi precisada definitivamente, foi possível verificar, de um modo insofismável, que ela é mais recente do que a série algonquiana de Brusque. Tem-se atualmente, para a série Itajaí, como muito provável, a idade siluriana inferior (período ordoviciano).

De especial importância para a estratigrafia, finalmente, devem ser consideradas as últimas pesquisas relativas à limitação das camadas gonduânicas superiores entre o permiano e o triássico. Por este motivo o desenvolvimento desta questão toma um maior vulto, pois se trata de fundamentar, se bem que em linhas gerais, as novas classificações estratigráficas. O problema já

\footnotetext{
${ }^{\wp}$ Artigo publicado no Arquivos de Biologia e Tecnologia, v. 2, pp. 63-154, 1947.
} 
foi apresentado com os trabalhos de MENDES (1945, A). Referia-se este problema particularmente à limitação inferior do triássico com as camadas permianas Estrada Nova, baseado em fósseis determinados por COWPER REED. Nota-se facilmente que o problema não é de caráter local, mas abrange a totalidade das camadas gonduânicas no Brasil Meridional (MENDES, 1944; 1945, C).

Das comparações realizadas no campo entre o perfil clássico de WHITE (1908), na Serra Geral ao oeste de Lauro Mueller, em Santa Catarina, e em Santa Maria da Boca do Monte, no Rio Grande do Sul, e também dos estudos de mais 7 perfis, relativos à zona de limitação em questão, em Santa Catarina e no Paraná, efetuados, após a realização do $2^{\circ}$ Congresso Pan-Americano de Engenharia de Minas e Geologia, por Kenneth E. Caster, Mackenzie Gordon JR., Josué Camargo Mendes e o autor deste, resultou que a limitação estratigráfica das camadas gonduânicas superiores do Brasil Meridional não pode ser mantida. Os resultados preliminares destas pesquisas e a nova estratigrafia das camadas gonduânicas são apresentados, pela primeira vez, para o Paraná e Santa Catarina, nas linhas fundamentais que se seguem. Maiores detalhes destas pesquisas realizadas continuamente entre o Rio Grande do Sul e o Paraná, com o auxílio eficiente do Instituto de Biologia e Pesquisas Tecnológicas em Curitiba, aqui não podem ser indicados; os geólogos que dela participaram apresentarão, a seu tempo, outras informações.

Nas linhas seguintes trataremos da constituição geológica dos Estados do Paraná e Santa Catarina somente em linhas gerais e, com capítulo à parte, dos elementos dessa constituição e das suas diversas formações, segundo o estado dos conhecimentos até 1947. As jazidas minerais de utilidade prática não são consideradas, uma vez que sobre este assunto foi previsto outro trabalho. Considerando que estas explanações devem acompanhar, em primeiro lugar, a nova representação cartográfica e geológica do Paraná e Santa Catarina, para o "Geological Map of South América", prescindiu-se, ab initio, da apresentação de numerosas particularidades e fenômenos morfológicos, como de descrições petrográficas e resumos paleontológicos. A bibliografia, a pedido especial, foi reduzida ao estritamente necessário.

\section{TRAÇOS GERAIS DAS PESQUISAS GEOLÓGICAS}

\author{
A - PARANÁ
}

As primeiras notícias, gerais e resumidas, sobre a geologia foram dadas por H. Neumann, em 1860; H. P. Verecker, em 1862; José e Francisco Keller, em 1866; e Luther Wagoner, em 1878. Uma boa descrição geral do Paraná foi fornecida em 1885 por Henry Lange, em seu livro sobre o Brasil Meridional. Os trabalhos básicos mais importantes para a geologia do Paraná são representados pelas publicações de O. A. Derby, em 1879 e 1883; Josef v. Siemiradski, em 1898; I. C. White, em 1908; e J. B. Woodworth, em 1912, e pelas notas paleontológicas de E. Kayser, em 1900, e algumas comunicações de H. Bross, em 1909 e 1910.

No ano de 1913 foi publicado o mais importante dos trabalhos paleontológicos sobre os fósseis devonianos, por J. C. Clarke, e, logo após, os trabalhos fundamentais de Euzébio Paulo de Oliveira, em 1913, 1916, 1918 e, mais tarde, em 1927, com caráter monográfico, a primeira representação total da geologia do Paraná. A esta monografia Euzébio Paulo de Oliveira fez seguir, em 1929, 1930, 1936 e 1937, importantes comunicações relativas à estratigrafia, paleontologia e aos recursos minerais, tendo fornecido, portanto, a base principal para a geologia do Paraná.

Entre as publicações mais recentes sobre a geologia geral devem ser mencionadas, em primeiro lugar, as seguintes: Reinhard Maack, em 1932, 1934, 1937, 1940, 1941 e 1946; Viktor Oppenheim, em 1934 e 1936; Paulino Franco de Carvalho, em 1936, 1937, 1939, 1940 e 1941. Quanto aos trabalhos especiais sobre petrografia e jazidas minerais, devem ser referidos os seguintes: Viktor Leinz, em 1936, 1937 e 1940; Glycon de Paiva, em 1940; Djalma Guimarães, em 1931 e 1933; relativos à paleontologia: Karl Holdhaus, em 1919; L. Hussakof, em 1930; F. R. Cowper Reed, em 1929, 1935, 1940 e 1942; Charles W. Read, em 1941; Frederico W. Lange, em 1941 e 1942. Indicamos ainda algumas comunicações: Ildefonso A. Erichsen, em 1940; Josué Camargo Mendes, em 1945; Setembrino Petri, em 1945; Fernando F. M. de Almeida, em 1945. São citadas também as informações sobre pesquisas geofísicas de Décio Saverio Oddone, em 1938 e 1939, como também os mapas geológicos do Estado do Paraná de 
Euzébio P. de Oliveira, em 1925 (1: 1.000.000) e Reinhard Maack, em 1938 (1:2.000.000) e 1945 (1: 250.000). Finalmente devem ser mencionados os recentes trabalhos realizados no Instituto de Biologia e Pesquisas Tecnológicas em Curitiba, constantes de contribuições para a geologia geral (J. J. Bigarella), petrografia química (A. Leprevost), agro-geologia (C. Bodziak e R. Maack) e geologia das fontes das águas minerais (R. Maack e R. Spitzner).

\section{B - SANTA CATARINA}

Tanto os trabalhos mais antigos sobre a geologia de Santa Catarina como os mais recentes se ocupam principalmente da ocorrência de carvão de pedra, assim Julio Parigot, em 1841-1842; Edward Thornton, em 1867 e Natanael Plant, em 1869. Porém, os autores mais antigos também já publicaram representações gerais das condições geológicas em apreciações pouco extensas ou em trabalhos geográficos. Entre estes autores se encontram: C. van Lede, em 1843-1846; Fr. Burlamaqui, em 1856-1858; Woldemar Schulz, em 1895 e, principalmente, Henry Lange, em 1885 e 1888, nas suas publicações sobre o Brasil Meridional. Merecem citação ainda Alfred Hettner, em 1890; Carl Ballod, em 1892 e Luiz Gonzaga de Campos, em 1888 e 1891.

O material cientificamente mais importante foi fornecido por I. C. White, em 1908, no seu bem conhecido "Report on the Coal Measures and Associated Rocks of South Brazil", trabalho em que o autor também fundou o "Sistema Santa Catarina". Seguem-se os trabalhos de Euzébio P. de Oliveira, em 1918, e os levantamentos e publicações mais recentes sobre a geologia geral, paleontologia e jazidas minerais por E. Bourdet Dutra, em 1926; Anibal Alves Bastos, em 1929; P. José Pauwels, em 1929; Glycon de Paiva, em 1933; Flores Moraes Rego, em 1926, 1933 e 1935; Reinhard Maack, em 1934 e 1937; Paulino Franco de Carvalho, em 1936, 1937, 1938, 1940 e 1942, assim como por João Miranda, em 1942. Quanto à paleontologia, mencionamos Carlota Joaquina Maury, em 1927; Reinhard Maack, em 1929; F. R. Cowper Reed, em 1929, 1930, 1940 e 1942, como Charles B. Read, em 1941; com relação à petrografia, Djalma Guimarães, em 1931; Otavio Barbosa, em 1936 e 1940; Ruy Osório de Freitas, em 1945 e Mackenzie Gordon Jr., em 1946. Além destes foram publicados ainda trabalhos sobre pesquisas geofísicas por Mark C. Malamphy e J.
C. do Amaral, em 1937 e, finalmente, com relação às jazidas, por J. Fiuza da Rocha, em 1925, 1928, 1940 e 1941; e Evaristo Pena Scorza, em 1939 e 1940, como também esboços geológicos provisórios e mapas por I. C. White, em 1908 (1 : 2.010.365), Reinhard Maack ( $1: 2.750 .000)$ e pelo Serviço Geológico e Mineralógico do Brasil, em 1939 (1: 1.500.000).

\section{TRAÇOS FUNDAMENTAIS DA CONSTITUIÇÃO GEOLÓGICA E DA CONFIGURAÇÃO DA SUPERFÍCIE}

\section{A - GENERALIDADES}

As regiões dos Estados do Paraná $\left(199.897 \mathrm{~km}^{2}\right)$ e Santa Catarina $\left(94.998 \mathrm{~km}^{2}\right)$ representam uma parte da grande região geológica da antiga Terra de Gonduana. Formam maciços parciais da região sul-brasileira, mostrando limitações nítidas e, assim, zonas de paisagens naturais. O limite setentrional desta região contra o Estado de São Paulo segue os talvegues do rio Paranapanema, que é um rio antigo conseqüente do plano de declive, e do rio Ribeira de Iguape, relativamente recente, originado tectonicamente. Para o sul, a região a descrever é limitada contra o Estado do Rio Grande do Sul pelo vale de declive do rio Uruguai e pela escarpa da Serra Geral com o rio Mampituba, o qual é um rio litoral e da testa da escarpa. Entre o Paraná e Santa Catarina, o vale de base larga de aluviões (Sohlental) do rio Iguaçu com o rio Negro traça o limite até a entrada na escarpa triássico-jurássica em Porto União, atingindo, rio Jangada acima, o divisor das águas entre o rio Iguaçu e o rio Uruguai. Desde que o Território Federal do Iguaçu foi reincorporado aos Estados, o Estado do Paraná é limitado no oeste pelo rio Paraná e o rio Iguaçu com o pequeno tributário rio Santo Antônio, enquanto que o rio Peperí-Guaçú separa politicamente o Estado de Santa Catarina do território das Missões, na Argentina, o qual, geologicamente, representa parte integrante do derrame eruptivo básico da bacia do Paraná e do planalto de declive do interior catarinense.

Os Estados do Paraná e Santa Catarina, na maior parte da sua extensão, são constituídos por um planalto que mergulha suavemente para NW. W e SW, cuja plataforma estrutural circunscreve o complexo das rochas cristalinas, em forma de domo, por meio de um arco, ou melhor, formando 
quase um ângulo reto com a abertura voltada para leste, ângulo este, motivado por linhas de estrutura geológica. As rochas cristalinas representam a base de deposição, truncadas por paleoplanos, para os sedimentos paleozóicos e mesozóicos, não mais perturbados por movimentos orogênicos, de modo que ainda jazem em camadas horizontais ou levemente inclinados. As maiores elevações do complexo cristalino acham-se no Estado do Paraná. O pedestal cristalino cai abruptamente numa marcante escarpa de falha ou em escadas de falhas, em direção ao mar (fig. 20, 21 e 24), causando assim o característico mais pronunciado na fisionomia da superfície dos Estados do Paraná e Santa Catarina, a saber, a separação em duas regiões naturais: a região litorânea e o planalto do interior (Kuestenland und Binnenhochland).

Pela posição não perturbada e pelo suave mergulho das chapas de sedimentos para NW, W e SW, no interior do Paraná e Santa Catarina, desenvolveu-se uma paisagem de degraus estruturais, através de toda extensão do planalto do interior, coberto por camadas gonduânicas do paleozóico e mesozóico. Cada degrau estrutural forma um arco ou ângulo reto, com a testa dirigida para leste, abrangendo o complexo cristalino abaulado em forma de domo, por exemplo, a escarpa devoniana no Paraná (Serrinha, Serra das Furnas, etc.) e a escarpa triássico-jurássica (Serra Geral, Serra do Espigão e Serra da Esperança) em Santa Catarina e no Paraná (ANEXO II e perfis geológicos).

Enquanto que no Estado do Paraná, como também no de São Paulo, o litoral é uma faixa bastante estreita, formando apenas uma zona de transição ou uma passagem para o oceano $(4,8 \%$ da população), o litoral no Estado de Santa Catarina, com as suas cadeias de elevações e vastas planícies aluviais, abrange, aproximadamente, um terço da superfície do Estado e suporta, apesar do clima pouco propício - verão úmido e quente e malária $-71,5 \%$ da população $(23,8$ pessoas por quilômetro quadrado contra 4,8 no interior), sendo ainda a região econômica mais importante do Estado.

O motivo de considerar o Paraná, em primeira linha, como Estado de planalto ou do interior, e Santa Catarina como região marítima, é a grande escarpa do planalto brasileiro, já referida. Este degrau, chamado Serra do Mar, corre como escarpa de falha do sul da baia de Guaratuba para SW. Mergulhando sob os sedimentos paleozóicos e mesozóicos; no ápice da região tectônica da bacia do Itajaí - aproximadamente em $27^{\circ}$ de lat. sul e $50^{\circ} 15^{\prime}$ ao oeste de Greenwich - coberta pela possante capa de sedimentos gonduânicos, declina em ângulo agudo para SE, aproximando-se novamente da cuesta, agora como Serra Geral. Enquanto que a Serra Geral forma no planalto um dos mencionados degraus estruturais motivados pela erosão, no litoral ela cai abruptamente para o oceano - análogo a Serra do Mar no Paraná como escarpa de falha ou escadas de falha, com vales tectônicos e mesetas isoladas diante da escarpa. Por este motivo, às camadas gonduânicas formam a parte sul do litoral de Santa Catarina, estendendo-se entre Laguna e Torres sobre a plataforma continental. Deve-se notar, porém, que as falhas diante e na Serra Geral nunca exibem grandes diferenças de nível. Como a escarpa ou a borda (Randstufe) do planalto do interior recuou muitas vezes das linhas de falhas pela ação da erosão, a extensão total da frente da Serra Geral em Santa Catarina tomou o caráter fisionômico de uma legítima escarpa, originada pela erosão.

\section{B - PARANÁ (ANEXO II)}

Cinco paisagens principais naturais podem ser distinguidas no Estado do Paraná, determinadas pela escarpa de falha e pela serra marginal (Randgebirge) do complexo cristalino, como também pelos degraus estruturais do devoniano e do triássico-jurássico:

1) O Litoral*, que abrange tanto as porções de abaixamento do complexo cristalino, com as enseadas de ingressão, como as recentes regiões de entulhamento marinho e terrestre e as planícies de aluvião.

2) A Serra do Mar, com seu complicado tectonismo de falhas e zonas de maiores elevações das rochas cristalinas, formando uma serra marginal (Randgebirge), que sobrepuja os planos de nível do planalto do interior.

3) O Primeiro Planalto, ou Planalto de Curitiba, que representa uma zona de eversão (Ausraumgebiet) entre a Serra do Mar e a escarpa devoniana, zona que mostra um plano de erosão recente (junge Abtragungsfläche) sobre um antigo tronco de dobras o qual, por sua vez, é cortado ao norte pelos tributários do profundo vale do rio Ribeira, numa zona montanhosa recente.

\footnotetext{
* litoral = tradução dos termos "Kuestenland"e "Kuestenbergland", abrangendo toda a zona desde a grande escarpa até ao mar.
} 
4) O Segundo Planalto, ou Planalto de Ponta Grossa, nitidamente limitado com o complexo cristalino do primeiro planalto pela escarpa bem modelada dos arenitos devonianos que se encontram na base da chapa de sedimentos paleozóicos. Esta região mostra planos de declive suavemente abaulados, outeiros ou paisagens de mesetas das camadas gonduânicas.

5) O Terceiro Planalto, ou Planalto de Guarapuava, o qual é separado do segundo planalto pela cuesta marcante das rochas triássicas ou jurássicas da capa, - arenitos São Bento com o derrame de rochas eruptivas básicas - mostrando no seu plano de declive (a encosta da escarpa) chapadas e platôs dos lençóis de trapp da bacia do Paraná e as mesetas e suaves ondulações dos arenitos suprabasálticos mais recentes.

\section{1) O Litoral}

O litoral do Paraná representa uma estreita faixa montanhosa que afundou por falhas do planalto, cujos vales antigos constituem as enseadas de ingressão de Paranaguá e Guaratuba. As cadeias de elevações e morros isolados desta paisagem são limitados, para o lado das enseadas e do mar, por extensas planícies de aluvião e pântanos, que margeiam as enseadas de ingressão e que, terra a dentro, abrangem também os funis de vales dos rios costeiros, como sinal duma maior extensão, não remota, da superfície das enseadas (fig. 1).

Diante da cuesta emergem, no mar aberto, como ilhas rochosas abruptas, cúpulas e domos gnaisgraníticos que jazem sobre a plataforma continental. Ilhas rochosas deste tipo já foram ligadas às extensas planícies arenosas litorâneas em grande número, pela acumulação de sedimentação marinha e terrestre (fig. 48).

O litoral é constituído, em sua maior parte, por gnaisses arqueanos do escudo primitivo Brasilia com granitos intrusivos. Porém, rochas algonquianas, como xistos micáceos, quartzitos, itabiritos, filitos, e calcáreos, também participam da sua constituição. São elas encontradas especialmente na parte norte do litoral, no curso inferior do rio Itaquí, e ao norte de Guaraqueçaba até a região limítrofe com o Estado de São Paulo. Grandes blocos e lentes destas rochas, altamente metamórficas, são observados igualmente no próprio escudo gnáissico diante da Serra do Mar, assim entre Cacatú e Cachoeira, na bacia do rio Curitibaíba, e diante da própria Serra da Prata.
Diretamente sobre as rochas cristalinas antigas foram depositados, finalmente, os sedimentos não consolidados do quaternário.

Que a ruptura do litoral é, geologicamente, recente, ressalta tanto da disposição das escarpas de falha e das escadas de falha como do desenvolvimento morfológico dos degraus, das escadas (Staffeln) e dos blocos isolados. Segundo todas as observações, as falhas recentes tiveram lugar no percurso do terciário, tendo se iniciado, talvez, já no fim do cretáceo. Devem ser relacionados com o tectonismo dos Andes, pelo qual se originaram, na orla continental leste, desequilíbrios e tensões na crosta siálica que produziram zonas de afundamentos. Assim os vales de uma antiga superfície terrestre preterciária foram mergulhados no mar, constituindo atualmente as enseadas de ingressão da faixa litorânea. Compensadas as tensões tectônicas iniciaram-se, no quaternário antigo, isto é, no pleistoceno, processos de ascensões epirogênicas, que continuam na atualidade. O ritmo destas ascensões pode ser observado nos níveis de erosão antigos, planos de abrasão, cavas de ressaca e cliffs (falésias) ao longo das elevações litorâneas (fig. 18), como também nas ilhas rochosas ligadas às planícies arenosas da cuesta e nas altitudes dos planos de sedimentação marinha, tabuleiros. Os dois níveis de ascensão mais recentes se encontram a 1,30 e 3,50 m acima da maior maré (Springflutmarke). Níveis bem marcados de cliffs, cavas de ressaca e planos de abrasão observam-se entre 7,50 e $10 \mathrm{~m}, 19$ e $21 \mathrm{~m}, 27$ e $35 \mathrm{~m}, 50$ e 65 $\mathrm{m}$, como entre 92 e $102 \mathrm{~m}$ e planos nítidos de erosão, ainda mais elevados, em $220 \mathrm{~m}$. O nível mais importante e mais pronunciado pode-se constatar entre 50 e $65 \mathrm{~m}$ sobre o nível do mar (fig. 128).

O desaguar dos riachos na planície litorânea, paralelos à cuesta, é determinado pelo acúmulo progressivo dos sedimentos em direção SSW NNE. Com isto não são dificultadas apenas as embocaduras dos rios sobre a praia, diretamente ao mar, mas formações de cordões litorâneos (Nehrungen) obrigam os cursos d'água a procurarem a sua foz sempre mais para o norte.

Manguezais (Mangroven) margeiam todas as partes internas e calmas das baias, como as embocaduras dos rios litorâneos, ainda no alcance das marés. A praia está completamente livre dos manguezais, apresentando uma planície arenosa, desprovida de vegetação, com um cliffs ou restinga 
de praia (Strandwall) como marca das marés de 1,5 a 3 m de altura (fig. 129).

Resumindo, as linhas gerais da constituição geológica do litoral paranaense mostram três fases orogênicas principais com concomitantes intrusões plutônicas extensas sob forma de batolitos, stocks ou facolitos:

1. No arqueano, um diastrofismo pre-oceânico, o mais antigo que pode ser observado no litoral paranaense, caracterizado pelo tectonismo de intrusão e que abrangeu somente os gnaisses mais antigos, plagioclásio-biotita-gnaisses. Este diastrofismo pre-laurentiano, com intrusão de microclina-biotita-granitito foi verificado também no Estado do Rio por A. R. Lamego, denominandoo "diastrofismo brasílico".

2. Um dobramento neo-arqueano (geralmente denominado laurentiano) que perturbou novamente o escudo gnáissico antigo, motivando a gnaissificação das intrusões graníticas anteriores (gnais-granitos e pórfiro-granito-gnais).

3. Um dobramento intensivo neo-proterozóico ou post-algonquiano respectivamente, com intrusões batolíticas e em áreas extensas, correspondendo à orogenia huroniano-penoqueana. A pressão do dobramento foi dirigida contra o escudo gnáissico antigo, abrangendo principalmente sedimentos geossinclinais, as rochas pre-cambrianas da série Açunguí, causando-lhes gnaissificação parcial (formação dos gnaisses mais recentes).

Durante o mesozóico (rético-liássico) originaramse as fendas de tração pelas quais ascenderam magmas básicos. O terciário é uma época de movimentos tectônicos, durante os quais o litoral foi imerso no mar. Movimentos epirogênicos durante o quaternário produziam a multiplicidade das formas morfológicas recentes da região litorânea com vastíssima sedimentação, acompanhando o movimento negativo da praia. Por este motivo, encontra-se no perfil geológico sedimentos quaternários depositados direta e discordantemente sobre as mais antigas rochas arqueanas.

\section{2) A Serra do Mar}

A Serra do Mar não representa no Paraná apenas o degrau entre o planalto do interior e o litoral, mas constitui uma serra marginal bem marcada que se eleva de 500 a $1000 \mathrm{~m}$ sobre o nível geral do primeiro planalto. Ela é repartida, por conjuntos de blocos altos e baixos, em maciços diversos, os quais receberam denominações regionais especiais. Os blocos mais elevados exibem os seus pontos culminantes sempre para NE, diminuindo em altura par SW.

O primeiro bloco de montanha isolado que se salienta é a Serra Capivari Grande (1694-1716 m, fig. 21 e 26). Deste bloco para o norte até o vale do rio Ribeira não se nota outra cadeia alta marginal que pudesse ser designada por "Serra do Mar". É esta a região em que se estende a série Açunguí algonquiana para a zona litorânea, uma região que geológica e geograficamente ainda não foi estudada.

Ao sul da Serra Capivari Grande eleva-se sobre o degrau o Guaricana, em bela forma tronco-cônica, com $1551 \mathrm{~m}$ de altitude s.n.m. (fig. 26). Começa depois no maciço da Serra Ibiteraquire (Serra Verde) a zona de maiores elevações da Serra do Mar no Paraná. Neste maciço, o autor verificou os cumes mais elevados representados pelo Pico Paraná com 1965,6 m e o Pico Caratuba com 1939 m (fig. 19). Na parte média da Serra Ibiteraquire (Serra Verde ou Serra dos Órgãos) vê-se o Pico Ciririca com paredões abruptos, originados pelas falhas, até $1781 \mathrm{~m}$ e a Agulha da Cotia até $1521 \mathrm{~m}$ s.n.m. (fig. 20 e 21 ).

Ao sul de um bloco baixo, da Serra São João, com cotas entre 930 e $1002 \mathrm{~m}$, ressalta-se, um pouco afastado da frente da Serra Ibiteraquire, a Serra da Graciosa, com escarpamento de falha a pique com dois degraus em diferentes alturas (Staffeln ou escadas de falha). A partir do Alto da Graciosa, com $1472 \mathrm{~m}$, este bloco de serra perde em altitude para SW, mostrando na Serra da Farinha Seca 1184 e 1123 m s.n.m. (fig. 1). Separado pelo vale tectônico do rio Ipiranga eleva-se, novamente após um bloco baixo de $884-1001 \mathrm{~m}$, avançando muito para diante, mas sempre na direção geral da frente da serra NE-SW, o alto maciço da Serra Marumbi com o pico Marumbi (1547 m, fig. 20 e 23). Desaparece, aqui, a serra marginal, e o planalto termina bruscamente, caindo numa escarpa de 1000 a $1100 \mathrm{~m}$ de altitude diretamente para o litoral, ocasião na qual algumas cadeias de serras ramificam-se da escarpa, avançando grandes distâncias para a região litorânea (serras da Igreja, das Canavieiras e da Prata). Além da zona de Castelhanos, onde o primeiro planalto estende-se entre os profundos vales dos rios São João e Arraial com algumas elevações graníticas, começa a cadeia marginal da Serra do Mar somente na Serra Araçatuba (fig. 17 e 25) e na Serra Iqueririm $(1450 \mathrm{~m})$. Diante da parte sul da Serra do Mar desenvolvem-se algumas cadeias de montanhas 
paralelas, separadas da escarpa principal por vales de linhas de falhas. Nesta região são freqüentes os fenômenos de captação das cabeceiras dos rios do planalto pelos rios da testa da Serra do Mar.

Os altos maciços da Serra do Mar, como os picos Paraná e Marumbi, são constituídos por granitos e granito-pórfiros mais recentes, huronianos. $\mathrm{Na}$ Serra da Graciosa descansa ainda, em determinados lugares, a capa dos gnaisses antigos sobre os granitos mais recentes. Um stock de quartzo-(riolito-)pórfiro, provavelmente da orogenia caledoniano-taconiana, atravessa os granitos penoqueanos, no Pico Caratuba. Os flancos dos maciços graníticos mais altos são constituídos de granulitos claros e gnaisses lenticulares de granulação grossa. Ao sul da Serra Marumbi predominam rochas xistosas altamente metamorfizadas tais como micaxistos, gnaisses de injeção, paragnaisses e quartzitos com magnetita (quartzito-itabiritos metamorfizados). Nas serras Araçatuba e Iqueririm reaparecem as massas intrusivas dos granitos mais recentes, igualmente providas da capa gnáissica ou incluindo blocos de gnais. As linhas e planos de falha recentes, ou terciários respectivamente, constituem dois falhamentos longitudinais rumo $\mathrm{N} 25^{\circ} \mathrm{E}$ e $\mathrm{N} 60^{\circ} \mathrm{E}$, que se cruzam em ângulo agudo. Falhas transversais correm paralelamente aos diques de diabásio antigos na direção $\mathrm{N} 45^{\circ} \mathrm{W}$. Restos de antigos peneplanos bem pronunciados cortam níveis em forma de platôs nas serras Graciosa e Iqueririm entre as cotas de 1400 e $1450 \mathrm{~m}$ (fig. 20,24 e 25). A Serra Ibiteraquire caracteriza-se por truncaturas de paleoplanos no mesmo nível entre 1400 e $1450 \mathrm{~m}$ e, especialmente, por escadas de piedmonte (Rumpftreppen) entre 1750 e $1850 \mathrm{~m}$, como também por planos de erosão entre $1100 \mathrm{e}$ $1200 \mathrm{~m}$ e 850 até $950 \mathrm{~m}$ (fig. 22). Um perfil topográfico, tomado do pico Marumbi, elucida melhor as formas da grande escarpa da serra marginal (fig. 1).

\section{3) O Primeiro Planalto}

O primeiro planalto entre a Serra do Mar e o degrau estrutural mais a leste dos sedimentos paleozóicos, dispostos quase horizontalmente, - da escarpa devoniana - mostra, numa extensão de 75 $\mathrm{km}$, altitudes notavelmente uniformes de 850 a $950 \mathrm{~m}$ duma paisagem, suavemente ondulada, com planícies de sedimentos fluviais e paludais do quaternário recente, jazendo diretamente sobre as rochas cristalinas antigas (ANEXO II; fig. 1).
As rochas cristalinas, gnaisses levemente dobrados como tecto sobre ou, fortemente dobrados, como blocos entre granitos post-algonquianos (hurinianos-penoqueanos) e caledonianos da fase taconiana, formam o pedestal do primeiro planalto desde a serra do Mar até ao oeste de Curitiba. Depois o escudo gnáissico antigo é cortado discordantemente, na direção de $\mathrm{N} 40^{\circ}-60^{\circ} \mathrm{E}$, pelas rochas algonquianas da série Açunguí - filitos, calcáreos e quartzitos - que constituem o primeiro planalto até o vale do rio Ribeira profundamente entalhado. Para oeste as camadas algonquianas, com granitos intrusivos e quartzo-pórfiros de Castro, mergulham sob o arenito das Furnas eodevoniano, constituindo o pedestal da escarpa. A parte sul do primeiro planalto é somente pouco conhecida geologicamente. Possivelmente se encontram aí extensas regiões de gnaisses mais recentes, como se observam a oeste de Curitiba, entre Passa Una e Campo Largo.

A superfície do primeiro planalto corta regularmente as rochas arqueanas e algonquianas com seus granitos e granito-pórfiros intrusivos. No pedestal da escarpa devoniana encontra-se o nível superior das rochas cristalinas 200-300 m mais alto do que no primeiro planalto, entre as cotas de 1120 e 1140 m, onde elas são cortadas por um peneplano paleozóico, ainda conservado sob as camadas protetoras. $\mathrm{O}$ peneplano predevoniano inclina-se suavemente com $0^{\circ} 30^{\prime}$ para $\mathrm{SW}$ e W. Prolongado para leste, este peneplano corta a Serra do Mar entre altitudes de 1450 e 1550 m s.n.m., num nível caracterizado pelos restos de antigos peneplanos na serra marginal (fig. 20, 22, 24 e 25). Por baixo desta linha de nível do paleoplano, suavemente inclinado, as rochas entre a Serra do Mar e a escarpa devoniana foram expostas pela erosão causada pelos rios subseqüentes $\mathrm{e}$ obseqüentes e removidas lateralmente pelos rios principais de declive, de modo que o atual primeiro planalto representa uma zona de eversão com um nível de denudação recente sobre um antigo tronco de dobras. Do norte, este plano de denudação recente é retalhado pelos afluentes do profundo vale do Ribeira (145 m s.n.m., em Paranaí), com sua base de erosão, pouco distante, no oceano Atlântico, e transformado numa região montanhosa recente, cujas linhas de cristas ainda se encontram no nível do primeiro planalto (fig. 28). 
Como zonas de maior resistência - hogbacks ${ }^{*}$ elevam-se sobre o nível geral do primeiro planalto cabeços de estratos de quartzitos e calcáreos da série Açunguí, constituindo longas cadeias de elevações íngremes como, por exemplo, a Serra Ouro Fino, com 1025-1150 m, a Serra da Bocaina, com 1200-1300 m, a Serra do Canha ou Paranápiacaba, com 1200-1300 m, a Serra Piraí, com 1080-1150 m (fig. 30 e 31).

Nas colinas de Curitiba jazem depósitos de argilas esverdeadas, roxas e pardo-avermelhadas, com 5 a $20 \mathrm{~m}$ de espessura, e faixas de seixos fluviais grossos e de cascalho fino (fig. 122). Na literatura geológica, estes sedimentos são considerados como terciários de Curitiba, mas também são referidos como depósitos quaternários. A diminuta diagênese destas argilas e seixos faz supor, como mais provável, uma idade pleistocena. A isto corresponde também a sua posição sobre os outeiros, aproximadamente $40-60 \mathrm{~m}$ sobre o nível dos sedimentos soltos do quaternário recente. Esta diferença de altitude está de acordo com o nível principal dos sinais das ascensões epirogênicas no litoral desde o quaternário antigo.

Também no primeiro planalto encontramos as mesmas fases de intrusão e dobramento orogênico como no complexo cristalino do litoral e na Serra do Mar, a saber:

1. A orogenia neo-arqueana ou laurentiana com granitos antigos, tendo abrangido exclusivamente gnaisses antigos, com a orientação de $\mathrm{N} 60^{\circ}-70^{\circ} \mathrm{E}$.

2. O dobramento huroniano com granitos penoqueanos que atingiu principalmente as camadas algonquianas, tendo fornecido os granitos mais recentes em forma de domos elevados na Serra do Mar. A direção deste dobramento, na parte leste, se adapta à do escudo gnáissico antigo com $\mathrm{N} 60^{\circ} \mathrm{E}$, porém, de um modo geral, desenvolve-se rumo $\mathrm{N} 40^{\circ} \mathrm{E}$.

3. A fase taconiana da orogenia caledoniana com granitos, granito-pórfiros e quartzo-pórfiros, cujas linhas de dobras percorrem a direção geral de $\mathrm{N} 20^{\circ}-30^{\circ} \mathrm{E}$.

Uma falha antiga com uma brecha de falha corta as dobras post-algonquianas diante da Serra Ouro Fino, rumo $\mathrm{N} 40^{\circ} \mathrm{E}$. Terraços nos vales e erosão fluvial rejuvenescida provam processos de ascensão epirogênica também no primeiro planalto.

\section{4) O Segundo Planalto}

* como "Schichtkopf-Relief".
Os sedimentos paleozóicos do devoniano e das camadas gonduânicas, que caracterizam o segundo planalto, além de uma suave curvatura côncava para oeste em direção à bacia do Paraná, não sofreram perturbações orogênicas. Constituem, pela sua posição suavemente inclinada, uma paisagem de degraus estruturais típica, com as testas das escarpas voltadas para leste (fig. 32).

O segundo planalto é limitado com o primeiro, formado de rochas cristalinas, pela escarpa devoniana e com o terceiro planalto pela escarpa triássico-jurássica (fig. 38 e 41). As altitudes da testa da escarpa devoniana oscilam entre 1090 e $1200 \mathrm{~m}$. Diante da escarpa triássico-jurássica as altitudes sobre o nível do mar variam de 750 até $775 \mathrm{~m}$, com cortes de vales na entrada da escarpa com $445 \mathrm{~m}$ de altitude no rio Ivaí, $490 \mathrm{~m}$ no rio Tibagí e $735 \mathrm{~m}$ no rio Iguaçu. Todas as camadas desde o devoniano até o jurássico denotam uma suave inclinação para oeste, à bacia do Paraná e para norte em direção ao rio Paranapanema (fig. 37). Na disposição total das camadas do segundo planalto reflete-se uma suave anticlinal, ou melhor, um abaulamento, em forma de domo, do complexo cristalino, cujo eixo principal é orientado aproximadamente dos saltos das Sete Quedas em direção E até SE. Tanto as camadas devonianas como as gonduânicas jazem sobre um peneplano antigo, bem formado que, na região do Paraná, representou um suave declive litorâneo primitivo.

O rio de declive principal do Paraná, o rio Iguaçu, ingressa na escarpa devoniana por um boqueirão (Durchbruchspforte) epigenético numa altitude de 855 m s.n.m. O rio Tibagí, com as suas várzeas de inundação e meandros no curso superior (fig. 123), avança para o primeiro planalto apenas por intermédio dos seus tributários, os rios Pitanguí e Iapó. O rio Iapó transpõe a chapa do arenito das Furnas por um pitoresco boqueirão de regressão, continuando em forma de cañon de 250-300 m de profundidade (fig. 33). Todos os rios principais do segundo planalto entram na escarpa triássicojurássica por imponentes boqueirões epigenéticos (fig. 38 e 41). Disto se conclui que os principais sistemas fluviais do Paraná são mais antigos do que a atual paisagem dos degraus estruturais, a qual apenas foi modelada pelo aprofundamento do antigo sistema hidrográfico em conseqüência da erosão. Especialmente na região do segundo planalto os rios mostram um rejuvenescimento dos seus vales motivado pela ascensão epirogênica. Todos os rios possuem numerosas corredeiras e 
quedas. Terraços nos vales e níveis de erosão (fig. 109 e 113) estão de pleno acordo com o ritmo de ascensão verificado na cuesta.

Como fenômenos notáveis de um vulcanismo triássico superior ou post-triássico ocorrem sistemas paralelos de diques de rochas eruptivas básicas, orientados na direção NW, que determinam o aspecto topográfico da superfície do terreno. Ao longo destes diques ou paralelamente às linhas de estrutura antigas podem ser observadas, no devoniano, falhas limitadas regionalmente rumo $\mathrm{NNE}\left(\mathrm{N} 28^{\circ} \mathrm{E}\right), \mathrm{NW}\left(\mathrm{N} 45^{\circ} \mathrm{W}\right)$ e N-S com diferenças de nível de 80 a $180 \mathrm{~m}$.

$\mathrm{Na}$ parte oeste do segundo planalto se desenvolvem fileiras de montanhas isoladas com capas de arenito Botucatu e largos diques de diabásio nas linhas de cristas, paralelas ao vale do Ivaí e à Serra da Boa Esperança como, por exemplo, nas serras dos Porungos, da Apucarana e dos Mulatos (fig. 37).

\section{5) O Terceiro Planalto}

O terceiro planalto representa o plano de declive ou a encosta da escarpa da Serra Geral no Paraná, idêntica à Serra da Boa Esperança ou à escarpa triássico-jurássica respectivamente. Os formadores da escarpa são os bancos de arenito São Bento inferior ou Botucatu com lençóis de trapp resistentes na capa, os quais, na frente da escarpa, apresentam a espessura de 50-200 m.

Os vales dos rios Ivaí, Piquirí, Iguaçu e Tibagí dividem o terceiro planalto em quatro blocos principais:

1. O bloco norte do planalto de Apucarana que inclina de $1100 \mathrm{~m}$ de altitude, na escarpa (Serra da Bufadeira), numa extensão de $150 \mathrm{~km}$, até $290 \mathrm{~m}$ no rio Paranapanema e numa extensão de $240 \mathrm{~km}$ para oeste até $235 \mathrm{~m}$ de altitude no rio Paraná;

2. O bloco médio do planalto do Campo Mourão $(650 \mathrm{~m})$, que tem na testa da escarpa, na Serra da Boa Esperança, num percurso de $265 \mathrm{~km}$, um declive de $1100 \mathrm{~m}$ de altitude para $225 \mathrm{~m}$ no rio Paraná;

3. O bloco sul do planalto de Guarapuava, com $1220 \mathrm{~m}$ na testa da escarpa, atingindo $550 \mathrm{~m}$ nas serras Boi Preto e São Francisco, onde cai abruptamente numa cuesta à $350 \mathrm{~m}$, mostrando na borda do cañon do rio Paraná 197 m s.n.m., enquanto que o rio corre no cañon $94 \mathrm{~m}$ mais baixo, tendo a água, no nível baixo, uma profundidade de $40-50 \mathrm{~m}$. Portanto, a base do cañon se encontra apenas 45 e 49 m s.n.m;
4. A parte nordeste do terceiro planalto de Araíporanga (ex-São Jerônimo), estende-se entre os rios Tibagí e Itararé. É relativamente baixa e desdobrada, pelos rios das Cinzas, Laranjinhas e Congonhas, numa série de mesetas e platôs pequenos. A parte do platô mais elevada tem um declive desde a Serra da Boa Esperança, ao sul de Araíporanga, de $1150 \mathrm{~m}$ até $300 \mathrm{~m}$ para o rio Paranapanema. A leste do rio Congonhas, como também entre os rios Laranjinhas e das Cinzas, algumas mesetas isoladas, avançando para o sul, mostram ainda cotas de cerca de $800 \mathrm{~m}$; geralmente, porém, as latitudes desta paisagem de platôs estruturais oscilam entre 300 e $650 \mathrm{~m}$.

A zona do planalto de Palmas $(1117 \mathrm{~m})$ Clevelândia $(975 \mathrm{~m})$, ao sul do rio Iguaçu, pertence ao plano de declive de Santa Catarina, formando no setor paranaense o declive do divisor de águas Iguaçu-Uruguai (Serra da Fartura) para o vale do rio Iguaçu, diminuindo a latitude de 1150 $\mathrm{m}$ para $300-700 \mathrm{~m}$. Sob o ponto de vista morfológico o ingresso do rio Tibagí no terceiro planalto é de especial interesse.

A constituição geológica do terceiro planalto é relativamente simples. Sobre os horizontes coloridos da formação Esperança e as camadas vermelhas, areno-argilosas do grupo Rio do Rasto, constituintes do pedestal da Serra da Boa Esperança, ou da escarpa triássico-jurássica respectivamente, começa, em toda a sua extensão, com uma discordância de erosão, o arenito terrestre Botucatu da série São Bento com paredões e alguns degraus, protegidos por lençóis de rochas básicas, diabásios, diabásio-porfiritos, meláfiros amidalóides ou também andesitos augíticos (fig. 38, 40 e 41).

Os poderosos lençóis de rochas eruptivas básicas alcançam uma espessura medida de 450-600 m, sem, contudo, ter sido observada a base dos mesmos. Estas camadas básicas ocupam toda a extensão do terceiro planalto, deixando exposto o arenito Botucatu em alguns vales do bloco norte do planalto de Apucarana.

No bloco norte do planalto de Apucarana, já a leste do rio Pirapó, em Sabaudia, jazem arenitos vermelhos supra-trapp, restos do arenito São Bento superior ou Caiuá. A oeste de Maringá as camadas eruptivas mergulham, numa altitude de aproximadamente $600 \mathrm{~m}$, sob uma chapa extensa de arenito Caiuá a qual avança, nesta região, em forma de língua do rio Paraná para leste, desenvolvendo-se ao longo do rio Paraná na largura total do bloco norte do planalto. A camada 
dos arenitos vermelho-castanho-escuros atinge até $270 \mathrm{~m}$ de possança sem, contudo, serem observadas nos planaltos do Paraná as rochas calcáreas cinzentas típicas da série Bauru cretácea, na base ou intercaladas no arenito.

No segundo bloco do planalto do Campo Mourão, o arenito Caiuá ocupa a largura total ao longo do rio Paraná, entre os rios Ivaí e Piquirí, avançando igualmente em forma de língua larga para leste sobre os lençóis eruptivos básicos. A chapa do arenito vermelho supra-trapp desaparece aproximadamente a $8 \mathrm{~km}$ a oeste de Campo Mourão, porém, a sudeste desta localidade, no divisor de águas entre os rios Cantú e Corumbataí, forma a capa de muitas mesetas e de pequenos platôs, com uma espessura de 20-60 m.

No terceiro bloco do planalto de Guarapuava, o arenito Caiuá encontra-se apenas numa pequena área, ao sul da foz do rio Piquirí, terminando a 4 $\mathrm{km}$ ao norte de Guaíra. O arenito Caiuá aflora no vale do rio Ivaí, imediatamente abaixo da corredeira de Ferro e no vale do rio Paranapanema além da corredeira do Diabo (fig. 114 e 115).

$\mathrm{O}$ aspecto da paisagem do terceiro planalto é determinado pelas formas de mesetas e platôs recortados do nível geral dos lençóis eruptivos (fig. 2). As linhas de serras mencionadas até agora nos mapas não ultrapassam o nível geral do platô, mas representam realmente chapadas ou linhas divisoras de água, levemente arredondadas, no nível do plano de declive.

$\mathrm{Na}$ parte inferior do vale do Ivaí encontram-se antigos terraços e bancos de conglomerados quaternários. Largos pantanais e várzeas de inundação de muitos quilômetros, com sedimentação paludal do quaternário recente, marginam o rio Paraná, o qual forma no seu próprio leito, ilhas instáveis, com material de decomposição, a saber, material rolado e areias recentes. No salto das Sete Quedas, em Guaíra, o Alto Paraná, com uma largura de 4 a $5 \mathrm{~km}$, precipita-se num cañon de 80 a $100 \mathrm{~m}$ de largura, num percurso de $45 \mathrm{~km}$, da cota de $220 \mathrm{~m}$ para a de 105 em Porto Mendes (fig. 42 e 45). A potência natural da massa de água precipitada nos saltos e no cañon estreito é calculada para o nível baixo de água de 6 a 8 milhões HP e para o nível alto de 18 a 20 milhões HP.

O cañon do rio Paraná (fig. 45) é uma formação geológica de idade pleistocênica até recente. O curso quaternário antigo abandonado do rio Paraná pode ser observado hoje $90 \mathrm{~m}$ mais alto a leste do cañon, com seus sedimentos fluviais e várzeas de inundação, desde Guaíra, até ao sul do rio São Francisco. Estes sedimentos fluviais e várzeas de inundação eoquaternários até recentes são atravessados pelos tributários menores do rio Paraná e retalhados tão profundamente que atualmente se encontram muito acima do nível dos vales destes rios. Todos os pequenos rios despencam abruptamente para o cañon do rio Paraná, amontoando nas gargantas de embocadura altos cones de areias que jazem sobre saliências das chapas de lava em forma de terraços (fig. 109). Os rios lançam-se em saltos ao cañon do rio Paraná, conforme o volume dos rios, ainda na própria parede do cañon ou mais ou menos afastados. Conseqüentemente, as quedas do rio São Francisco (a $4 \mathrm{~km}$ ) e os famosos, majestosos saltos do rio Iguaçu (a $21 \mathrm{~km}$ ) encontram-se mais afastados do cañon. A queda principal do "Salto Santa Maria" precipita-se na garganta do Diabo, em dois degraus de cerca de 3 e $69 \mathrm{~m}$, respectivamente num total de $72 \mathrm{~m}$, sobre diabásio-porfiritos laminados, capeando diabásios intersticiais e meláfiros amidalóides com heulandita. A potência útil dos saltos do rio Iguaçu é avaliada em apenas $300.000 \mathrm{HP}$, não atingindo, portanto, a das cataratas de Victória na África do Sul e nem a do Niagara (fig. 46 e 47).

\section{C - SANTA CATARINA}

Também em Santa Catarina, como no Estado do Paraná, o acidente geográfico mais notável é a grande escarpa terminal do planalto do interior com a destacada serra marginal, que desempenha um papel especial como elemento na formação da paisagem. Em virtude disto, distinguimos as seguintes regiões principais:

1) O Litoral*, com as enseadas de ingressão de São Francisco, Porto Belo e Laguna (fig. 49), representando, como no Paraná, uma parte afundada do complexo cristalino e formando a continuação direta do litoral paranaense. Em Santa Catarina, porém, observa-se articulação mais movimentada de cadeias e grupos de montanhas pelo desmembramento da Serra do Mar, para o sul, e maior extensão do litoral para oeste, com planícies de sedimentação marinha e terrestre muito mais vastas, como também constituição geológica mais variada.

\footnotetext{
* litoral = tradução dos temos "Kuestenland"e "Kuestenbergland", abrnagendo toda a zona desde a grande escarpa até ao mar.
} 
2) A paisagem da escarpa marginal (Randstufen-Landschaft) do planalto do interior, que em Santa Catarina não abrange apenas a escarpa de falha da Serra do Mar, mas também a Serra Geral com as camadas gonduânicas, dispostas horizontalmente, transgredindo sobre o pedestal cristalino, sendo a Serra Geral igualmente atingida pelo tectonismo do falhamento terciário.

3) O plano de declive do planalto do interior, sobre o qual se estende rumo NNW até Porto União a Serra Geral, como degrau estrutural bem pronunciado, na escarpa triássico-jurássica, aqui denominada Serra do Trombudo e Serra do Espigão. Diante desta cuesta jazem as camadas gonduânicas menos resistentes, desde os depósitos glaciais do grupo Itararé (carbonífero superior), até as camadas de coloração variegada do grupo Rio do Rasto da série Passa Dois (permiano superior). Esta parte do plano de declive do planalto de Santa Catarina representa uma continuação direta do segundo planalto do Paraná, enquanto que a região, coberta pelos lençóis eruptivos até a borda do degrau da Serra Geral, corresponde ao terceiro planalto do Paraná.

\section{1) O Litoral}

Ao sul do limite do Estado do Paraná prolongamse as planícies d'aluvião, originadas pela acumulação de sedimentação marinha e terrestre do quaternário recente, até o Rio Grande do Sul, mostrando freqüentemente ilhas rochosas aterradas como cúpulas isoladas (shantungs) do complexo gnais-granítico antigo. As planícies pantanosas mais recentes avançam para o interior, acompanhando os vales dos rios.

$\mathrm{Na}$ constituição geológica de Santa Catarina não ocorrem, como no Paraná, apenas as rochas cristalinas do escudo gnáissico com seus granitos intrusivos e as rochas algonquianas metamorfoseadas, mas também formações paleozóicas mais recentes do cambriano ou siluriano, vastamente distribuídas. Capas de camadas gonduânicas formam blocos de platôs e mesetas isolados diretamente sobre o embasamento cristalino. Particularmente, a parte sul do litoral é constituída por camadas gonduânicas que continuam sobre a plataforma continental.

A Serra do Mar, que se conserva integral no Paraná, já ao sul da escarpa da falha íngreme da Serra Iqueririm $(1450 \mathrm{~m})$ acha-se desmembrada em grupos de montanhas isolados paralelos, com altitudes de 300 a $600 \mathrm{~m}$, sobre as quais cortam restos de uma antiga peneplanície, anteriormente unida (fig. 54 e 57). Ao sul de Penha, o escudo gnáissico antigo é limitado por uma formação xistosa, fortemente inclinada, dirigida para N60$70^{\circ} \mathrm{E}$. Restos desta formação xistosa antiga de filitos pre-cambrianos e quartzitos itabiríticos (com magnetita e manganês) ocorrem já à oeste de Joinville. Pertence esta formação aos xistos cristalinos algonquianos, filitos, quartzitos e calcáreos da série Brusque, que formam a cuesta até aproximadamente $4 \mathrm{~km}$ ao sul de Cabeçudas, como também um pouco mais para o sul, em Porto Belo. Terra a dentro, a série Brusque acompanha especialmente o vale do rio Itajaí-Mirim (fig. 58). Ao sul de Queçaba (ex-Terezópolis) e a leste de Anitápolis ainda ocorrem as camadas algonquianas. São cortadas discordantemente por uma formação de xistos mais recente semimetamorfoseada, orientada no rumo $\mathrm{N} 20^{\circ} \mathrm{E}$ e que, às vezes, se apresenta apenas suavemente ondulada ou ainda quase horizontal. Ambas formações mergulham, já no litoral, sob as camadas gonduânicas. A formação de xistos mais recente alcança o vale do rio Itajaí-Açú, em Gaspar, acompanhando-o, rio acima, até Ibirama (ex-Hansa Hamônia); estende-se para NE até o vale do rio Luiz Alves. A formação Itajaí observase também ao sul de Queçaba, na região das cabeceiras do rio Capivari, em São Bonifácio, onde aflora nos vales dos riachos, em jazimento levemente perturbado, capeando os outeiros pouco elevados muitas vezes quase horizontalmente (fig. 62, 63 e 80 a 83).

Seguindo-se o vale do Itajaí-Açú mais acima (fig. 55 e 62), em direção a Rio do Sul (324 m) atingese, no alto dos paredões dos vales, o peneplano pre-gonduânico, que aí corta granitos e granitopórfiros caledoniano-taconianos, numa altitude de 350 e 420 m s.n.m. (fig. 3).

Aproximadamente $5 \mathrm{~km}$ a leste de Rio do Sul, o peneplano do embasamento granítico mergulha sob as camadas glaciais do grupo Itararé. A oeste de Rio do Sul e na região das nascentes do rio Itajaí-Mirim, mesetas predominam na paisagem (fig. 4).

A seqüência total das camadas das rochas cristalinas e dos sedimentos gonduânicos é cortada, como no Paraná, por diques de diabásio post-triássicos em direção $\mathrm{N} 45^{\circ} \mathrm{W}$ e injetada por plutonitos básicos, gabros e dioritos, da mesma idade. 
A formação de xistos mais recentes da série Itajaí foi anteriormente designada pelo autor como camadas de Anitápolis, baseando-se numa comunicação relativamente à ocorrência em ardósios escuros desta formação de um anelídeo fóssil do tipo siluriano superior "Oliveirania santacatharinae", descrito por Carlota Joaquina Maury. Nesta ocasião não eram ainda conhecidas as relações desta formação de xistos mais recentes com a série Itajaí, a qual, naquela época, constava como equivalente à série de Minas (MAACK, 1937, p. 12). Entretanto, o autor examinou no próprio lugar os "ardósios" de Anitápolis, verificando tratar-se indubitavelmente de varvitos escuros do grupo Itararé. Além disto, revelaram levantamentos e as últimas pesquisas a identidade da formação dos xistos mais recentes com a série Itajaí, assunto que será oportunamente tratado com mais detalhes.

Tão logo atingidas as regiões das camadas gonduânicas nos vales dos rios do Sul, do Braço do Norte ou também do Itajaí-Mirim, orientados paralelos à escarpa, ressaltam os vales de base larga, evidenciando, pela sua disposição que seguem, as linhas tectônicas (ver Mapa em anexo IV do artigo original - vol. 2, 1947, fig. 1 e 2).

Acompanhando a constituição geológica do litoral, de Cabeçudas para o sul, observa-se novamente, em Porto Belo, gnaisses antigos com granitos intrusivos. Perto de Camboriú jazem blocos calcáreos, altamente cristalinos - mármore incluídos por granitos em Toca Viola e no vale do rio Macaco. Depois de ter atravessado mais uma vez faixas da série Brusque, em Porto Belo e no vale do rio Tijucas, observa-se, até ao sul de Laguna e, terra a dentro, até Orleans, exclusivamente gnaisses, gnais-granitos e granitos mais recentes, tendo nos flancos das colinas restos de camadas glaciais do grupo Itararé, freqüentemente com disposição perturbada. Os últimos testemunhos da Serra do Mar circundam a baia de Laguna e mergulham ao sul e oeste sob as camadas gonduânicas (fig. 50 e 94).

No complexo cristalino verificam-se as orogenias arqueano-laurentiana, huroniana e caledoniana, cujas linhas de dobras são cortadas uniformente pelo paleoplano pre-gonduânico (fig. 54, 57, 60 e 61). Relacionados com o dobramento caledonianotaconiano das formações de xistos mais recentes da série Itajaí ocorrem, além dos plutonitos ácidos, também os respectivos vulcanitos - quartzopórfiros - e, como evidência do mais recente vulcanismo cretáceo, verificam-se, perto de
Anitápolis, magmas ricos em sódio, nefelinasienitos e fonolitos (apatita-piroxenitas e magnetita) com fenômenos hidrotermais em caldas a oeste de Cambirela e em Guarda.

$\mathrm{O}$ terciário é caracterizado por acentuados movimentos tectônicos, deslocações na borda continental, que produziram no litoral falhas longitudinais e transversais de pequena diferença de nível (Sprunghöhe). Os vales afundados e as ilhas rochosas da plataforma continental são ligados de novo ao continente pela sedimentação marinha e terrestre ocasionada pela ascensão epirogênica. Entre Imbituba e Laguna e, particularmente, entre Urussanga Velha e rio Araranguá são levantadas pelo vento dunas de areias movediças. Um grande campo de dunas encosta-se, ao sul do rio Araranguá, ao morro dos Conventos $(83 \mathrm{~m})$, uma meseta de camadas vermelhas da formação Rio do Rasto, donde um cordão litorâneo (Nehrung) obriga este rio a correr em direção norte. Com este grande cordão litorâneo começa a cuesta de liman típica do Brasil Meridional que se prolonga até o Uruguai (fig. 51, 53 e 133). Extensas lagunas atrás das dunas e carcaças de navios, que avançam terra a dentro, documentam a velocidade do efeito de arear nesta zona costeira. As planícies areadas e encharcadas não circundam apenas as enseadas de ingressão, mas também preenchem largos vales entre as cadeias montanhosas. Assim, a paisagem litorânea do Paraná e Santa Catarina se apresenta como antiga cuesta típica em rias que, apenas há pouco, desenvolveu a orla dos mencionados limans e cordões litorâneos com campos de dunas ou também restingas (Strandwälle) com vegetação ao redor das lagunas isoladas.

Como no Paraná, também diante da cuesta de Santa Catarina observam-se pequenas ilhas rochosas isoladas de gnais e granito, na plataforma continental, emergindo abruptamente do oceano. A ilha Santa Catarina (Florianópolis-Desterro) representa um arquipélago de ilhas gnáissicas maiores com intrusões graníticas mais recentes, ilhas estas ligadas entre si pela sedimentação marinha. Também aqui e na praia dos Ingleses foram levantadas pelo vento dunas de areia movediça, isolando uma grande laguna do oceano. Nas planícies de sedimentação recente da ilha Santa Catarina estendem-se vastos pântanos. Os sinais principais do levantamento epirogênico correspondem ao ritmo observado no Paraná, a saber, $1,30 \mathrm{~m}, 3,50 \mathrm{~m}, 7,50 \mathrm{~m}$ a $10 \mathrm{~m}, 27$ a $35 \mathrm{~m}$, 50 a $60 \mathrm{~m}, 92$ a $102 \mathrm{~m}$ e acima (fig. 48 a 50). 


\section{2) A paisagem da escarpa marginal (Randstufen-Landschaft)}

O pedestal gnáissico com granitos intrusivos antigos e mais recentes, constituindo a zona da escarpa de falha e a serra marginal da Serra do Mar no Estado do Paraná, com elevações até 1965 $\mathrm{m}$, desvia como escarpa contínua ou borda do planalto do interior, na Serra Iqueririm, repentinamente para SW. A escarpa é denominada, quando constituída pelo complexo cristalino, Serra São Miguel. A testa da escarpa atravessa-se no perfil Joinville - Campo Alegre ou Serra Alta, entre 850 e 960 m s.n.m., sendo que algumas elevações ultrapassam a borda da escarpa de falha, atingindo 1100 a $1200 \mathrm{~m}$ de altitude. Neste perfil encontram-se, acima dos gnaisses e granitos antigos, até a cota de $850 \mathrm{~m}$, rochas metamórficas, quartzitos e filitos da série Brusque algonquiana e, em 900 m, em disposição discordante, camadas de uma formação mais recente, arenitos, filonitos e camadas várvicas que lembram, à primeira vista, as camadas da série Itajaí, revelando-se, porém, depois de exame mais minucioso, ser camadas glaciais do grupo Itararé, perturbadas e transformadas pelo metamorfismo dinâmico e de contato (fig. 117). Ao sul da serra Iqueririm, o maciço cristalino da Serra do Mar se desfaz em cadeias e grupos montanhosos isolados; as rochas cristalinas, finalmente, constituem somente $\mathrm{o}$ pedestal da grande escarpa, desaparecendo sob as camadas gonduânicas.

Com o aparecimento das camadas gonduânicas, como novo elemento morfológico, no ângulo noroeste do rio Itajaí do Norte, predominam na paisagem formas de platôs e mesetas. A partir deste ponto, a escarpa aproxima-se, em direção SE, novamente da cuesta como Serra Geral, diante da qual situam-se escarpas de falhas, platôs e mesetas isoladas de camadas gonduânicas. A parte da escarpa, denominada Serra Geral, recuou já muito em conseqüência da erosão das linhas de falhas, revelando, por este motivo, pronunciadamente o caráter fisionômico de um legítimo degrau estrutural (fig. 64 e 65).

A Chapada da Boa Vista (1100 a $1240 \mathrm{~m})$ e, mais a oeste, a meseta de Faxinal Preto, representam escadas de falha (Staffeln) de camadas gonduânicas, levantadas em forma de pilar (horst), inclinadas para SW e isoladas da escarpa principal por vales de linhas de falha. As falhas longitudinais, difíceis de verificar, acham-se dirigidas no rumo $\mathrm{N} 50-60^{\circ} \mathrm{E}$. Porém, o grande número das falhas transversais predominantes pode ser, facilmente, seguido, apesar delas acusarem, muitas vezes, apenas alguns metros de diferença de níveis (Sprunghöhen). Estas falhas transversais que se desenvolvem nas direções $\mathrm{N} 290^{\circ} \mathrm{W}$ (magn.) e $\mathrm{N} 320-340^{\circ} \mathrm{W}$, freqüentemente cruzam-se, formando blocos em forma de cunha. As diferenças de nível das falhas foram medidas na maior parte com $40 \mathrm{~m}, 70 \mathrm{~m}, 90 \mathrm{~m}$ e, raras vezes, com $300 \mathrm{~m}$ (fig. 116 a 119).

A parte sul da grande escarpa corre na direção NNE - SSW, denominada regionalmente de Serra do Tubarão, Serra do Rio do Rasto e Serra do Oratório. A testa da escarpa encontra-se geralmente na cota 1250 a $1400 \mathrm{~m}$.

Algumas mesetas em forma de pilar (horst) elevam-se sobre a borda do planalto do interior, atingindo 1600 a $1700 \mathrm{~m}$ ou mesmo até $1870 \mathrm{~m}$ de altitude, ultrapassando, assim, o nível geral do planalto e igualmente a testa da escarpa. Em Lomba Alta $(923 \mathrm{~m})$ ergue-se o Morro do Trombudo, morro de testemunho, até a altitude de cerca de 1200 m s.n.m., e $10 \mathrm{~km}$ mais ao sul, destaca-se o horst do Morro da Boa Vista como meseta com $1810 \mathrm{~m}$ s.n.m. Junta-se ao sul de Lomba Alta e a leste de São Joaquim a zona das maiores elevações da Serra Geral, com mesetas e platôs de 1600 e $1700 \mathrm{~m}$, entre os quais salienta-se o Morro da Igreja, num horst maciço, com $1870 \mathrm{~m}$ de altitude, figurando até agora como ponto culminante do sistema orográfico de Santa Catarina. É provável que, ao norte do Morro da Igreja, no Campo dos Padres, existem elevações maiores que possivelmente ultrapassam a altitude de $1900 \mathrm{~m}$. Do Morro do Panelão o autor mediu trigonometricamente, com instrumentos simples, na direção $\mathrm{N} 160^{\circ} \mathrm{E}$ uma altitude de $1880 \mathrm{~m}$ e na direção $\mathrm{S}^{\circ} \mathrm{W}$ (azimute $185^{\circ}$ magn.) uma meseta com $1835 \mathrm{~m}$ de altitude s.n.m. Em virtude da determinação de distância ainda pouco precisa, deve-se ter em conta um erro médio de $\pm 10 \mathrm{~m}$ (fig. 5).

Aproximando-se do Rio Grande do Sul, tanto o planalto como a escarpa marginal baixam rapidamente de altitude, motivado pela inclinação geral para SW das camadas de sedimentos e do derrame das rochas eruptivas. $\mathrm{Na}$ extensão total da Serra Geral aflora, sem interrupção, a seqüência das camadas do Sistema Santa Catarina, desde as camadas glaciais paleozóicas do grupo Itararé até a capa superior das rochas eruptivas básicas 
mesozóicas. Os principais rios, como o Braço do Sul, seguem, nos vales da encosta da escarpa, linhas tectônicas, falhas e fendas de tração. Além disto, o aspecto da frente da Serra Geral é caracterizado pelo retalhamento efetuado pelos rios da testa da escarpa.

\section{3) O plano de declive do planalto do interior}

No planalto de Santa Catarina, o elemento morfologicamente mais importante é a enorme capa das rochas eruptivas básicas que, formando degraus, estende-se $315 \mathrm{~km}$ transversalmente sobre o planalto (ANEXO II). No pedestal da cuesta, constituída pelo lençol de trapp, que, como continuação da Serra da Boa Esperança, entra perto de Porto União no território do Estado de Santa Catarina sob a denominação de Serra do Espigão, ocorre em toda a extensão o arenito São Bento inferior ou Botucatu, formando paredões abruptos. Na base afloram, geralmente, as camadas mais argilosas e de coloração variegada do grupo Rio do Rasto da série Passa Dois.

Com a curvatura da cuesta do derrame eruptivo para oeste, circundando a zona de Lajes, a escarpa toma, desde o Morro do Funil, várias denominações regionais, tais como: Serra Verde, Serra Cantagalo, Serra Guará, Serra Pedra Branca, Serra Caneleiras, etc. A entrada dos rios Canoas e Caveiras no degrau estrutural, ou na cuesta respectivamente, divide o platô, formado pelo lençol de trapp, nos planaltos de Curitibanos, Serrito e São Joaquim. Seguindo-se a estrada Lajes (903 a 925 m) - Rio Pelotas, atinge-se, entre 940 e $1103 \mathrm{~m}$ de altitude, ao sul do rio Caveiras, o derrame de trapp do planalto. No perfil Serra Alta - Curitibanos transpõe-se o degrau na altitude de $1055 \mathrm{~m}$, descendo-se no perfil Caçador - Porto União de $1255 \mathrm{~m}$ até $735 \mathrm{~m}$ para o vale do rio Iguaçu (ver Mapa em anexo IV do artigo original vol. 2, 1947, perfis).

Da borda da escarpa do lençol de trapp, o planalto inclina-se para os rios Uruguai e Peperí-Guaçú até $200 \mathrm{~m}$ de altitude. Entretanto, a linha do divisor das águas dos rios Iguaçu e Uruguai mantém, na Serra da Fartura, a cota de 1100 a 1150 m e, na Serra Taquara Verde, a de 1200 a 1270 m. Em Bom Retiro, o platô de trapp desmembra-se em grupos de mesetas (fig. 66), atingindo, no morro do Panelão, altitudes até 1450 e $1470 \mathrm{~m}$. A Serra da Bocaina com 1100 a 1170 m s.n.m. representa uma ramificação da escarpa rumo SE - NW (fig. 107). A Serra da Farofa, recortada no derrame eruptivo, constitui um divisor de águas em forma de platô, notavelmente elevado, inclinando-se de $1700 \mathrm{~m}$ da região do Morro da Igreja $(1870 \mathrm{~m})$ até 1130 m, na estrada Lajes - rio Pelotas, passando depois, diminuindo sempre sua altitude, para a cochilha Rica que termina no ângulo da confluência dos rios Canoas e Pelotas. No perfil Lajes - Vacaria, o rio Pelotas aprofundou seu vale até $660 \mathrm{~m}$ s.n.m. (ver Mapa em anexo IV do artigo original - vol. 2, 1947, perfil 2a). A região, compreendida entre a borda do lençol de trapp da Serra Geral e o Peperí-Guaçú, e, entre a serra da Fartura e o rio Uruguai, é formada, exclusivamente, por meláfiros com drusas grosseiras, diabásios porfiríticos e diabásios intersticiais.

A partir do cone bem formado do Morro do Funil, a escarpa principal da Serra Geral desenvolve-se diretamente para Lomba Alta, com a testa dirigida para NE, constituída predominantemente por camadas gonduânicas menos resistentes. Apenas uma parte das mesetas, elevando-se aí sobre a escarpa, revela o arenito Botucatu e restos do derrame eruptivo básico. A testa da escarpa, no percurso para o planalto, cruza-se em Lomba Alta entre 923 e $1081 \mathrm{~m}$, e em $925 \mathrm{~m}$ a oeste de Serra Alta. Toda a região do planalto de Santa Catarina diante da escarpa, formada pelo lençol de trapp e pelo arenito Botucatu, é constituída, exclusivamente, pelas camadas gonduânicas argilosas e areno-argilosas, menos resistentes (ANEXO I).

A parte nordeste, entre Campo Alegre e Porto União, ao sul dos rios Negro e Iguaçu, representa continuação direta do segundo planalto do Paraná. Contudo, falta em Santa Catarina a limitação em forma de cuesta com o complexo cristalino. As altitudes sobre o nível do mar, nesta parte do platô, oscilam de $875 \mathrm{~m}$ em Campo Alegre, $793 \mathrm{~m}$ em Mafra a $735 \mathrm{~m}$ em Porto União. No perfil Campo Alegre - Porto União afloram todas as camadas gonduânicas, sedimentos glaciais do grupo Itararé, que ocupam a maior extensão deste perfil, até as camadas vermelhas do grupo Rio do Rasto. Estas últimas, juntamente com o arenito Botucatu e o lençol de trapp, formam o pedestal da escarpa triássico-jurássica. Entre Valões e Poço Preto são encontrados os horizontes vermelhos, dos quais $\mathrm{F}$. R. Cowper Reed descreveu os filópodos permianos, Estheria e Leaia; estes horizontes não pertencem às camadas Estrada Nova s. str., como são indicados geralmente, mas sim às camadas Rio do Rasto. 
Na zona de reentrância do derrame de trapp, a oeste de Lajes e na região entre a Serra Geral e o degrau estrutural do lençol eruptivo, ocorrem mormente camadas do grupo Estrada Nova; com espessura diminuta observam-se horizontes de coloração variegada da formação Esperança e, finalmente, as camadas vermelhas do grupo Rio do Rasto, ou da formação Poço Preto respectivamente. No perfil Serra Alta - Ponte Alta, o planalto tem altitudes pouco variáveis que, a oeste da testa da escarpa (925 a $940 \mathrm{~m}$ ), oscilam de 860 a $894 \mathrm{~m}$, sendo os vales dos rios d'Areia e do Tigre entalhados até $840 \mathrm{~m}$ e $846 \mathrm{~m}$, respectivamente (ver Mapa em anexo IV do artigo original - vol. 2, 1947, perfis).

No km 99 da estrada Lombo Alta - Lajes ocorrem, desde a cota de $897 \mathrm{~m}$, horizontes das camadas Terezina que afloram mais a oeste, no $\mathrm{km} 78$, na margem do rio Canoas, entre as altitudes de $862 \mathrm{~m}$ e $902 \mathrm{~m}$. No km 74 começam os horizontes de coloração variegada, sem calcáreos, da formação Esperança, capeados, no $\mathrm{km} 66$ da subida à serra do Bocaina, pelas camadas vermelhas, argilosas, típicas do grupo Rio do Rasto. Nestas rochas vermelhas, argilosas e finamente laminadas do grupo Rio do Rasto encontra-se, pouco aquém do $\mathrm{km} \mathrm{65,} \mathrm{na} \mathrm{cota} \mathrm{de} 1942 \mathrm{~m}$, a fauna de filópodos de Valões com Estheria. A base dos arenitos argilosos vermelhos, que correspondem ao fácies Pirambóia em São Paulo, encontra-se cerca de um metro acima destas camadas com Estheria e a do arenito Botucatu eólico cerca de $19 \mathrm{~m}$ acima das mesmas (fig. 104 e 107).

No lado sudoeste da serra da Bocaina percorre uma falha rumo SE - NW, inclinando-se todas as camadas para a serra. Uma segunda fenda com afloramentos de diabásio, orientada $\mathrm{N} 60^{\circ} \mathrm{E}$, cruza a direção da falha. Glycon de Paiva observou uma outra falha na frente NE da Serra da Bocaina que, por nós, não foi encontrada. Glycon de Paiva interpretou, por este motivo, a Serra da Bocaina como horst. Quanto às falhas, pode-se tratar apenas de pequenas diferenças de nível, como aliás, ressalta da comparação das altitudes das camadas Rio do Rasto e arenito Botucatu com as altitudes normais destas camadas nesta região.

A oeste da Serra da Bocaina encontram-se, regularmente, as camadas Estrada Nova nos vales e os horizontes do grupo Rio do Rasto nas elevações. Madeiras fósseis - Tietea e Dadoxylon entre outras - foram por nós colhidas nos folhelhos escuros típicos das camadas Estrada Nova s. str. a $18 \mathrm{~km}$ a leste de Lajes.
Aproximadamente a $9 \mathrm{~km}$ a leste de Lajes, as camadas gonduânicas foram cortadas por um stock de fonolito-tinguaito, relacionado com injeções extensas de eleolito-sienito mais recentes do que o derrame eruptivo básico da bacia do Paraná. O stock de fonolito eleva-se, no Morro do Tributo (fig. 67), até $1220 \mathrm{~m}$ duma região com cotas de 850 a $880 \mathrm{~m}$. A penetração dos magmas alcalinos nas camadas gonduânicas provocou um abaulamento das camadas sedimentares ao redor do Morro do Tributo, de modo que a lapa das camadas Estrada Nova aparece na superfície da terra. Em conexão com as injeções de nefelinasienito ocorrem limburgitos e augititos. Verificamos também diferenciações ácidas, supersaturadas, do tipo riolitóide.

\section{OS ELEMENTOS}

DA

De todos os elementos da constituição geológica dos Estados do Paraná e Santa Catarina, são as rochas do complexo cristalino as menos examinadas. Por este motivo, somente com reservas é possível de dar atualmente um sumário geral sobre as rochas do complexo cristalino, sua divisão estratigráfica e sua disposição. O Serviço Geológico do Estado do Paraná, nos moldes do programa do Instituto de Biologia e Pesquisas Tecnológicas, acaba de iniciar os serviços sistemáticos de levantamento geológico e estudos petrográficos. O petrógrafo-geólogo moderno encontra aqui um vasto campo de pesquisas.

Muito melhor se conhece os elementos da constituição das camadas sedimentares paleozóicas e mesozóicas com seu conteúdo fossilífero. Mas, também aqui, ainda tem muitos problemas a resolver relativamente à divisão das rochas sedimentares e à sua classificação estratigráfica. Seja mencionado apenas o problema relativo à limitação entre o permiano e o triássico e referente à idade geológica (triássica ou jurássica ?) do arenito Botucatu e do lençol de trapp do Paraná.

Nas seguintes explanações indicamos uma nova divisão estratigráfica, baseada nos resultados das pesquisas mais recentes, diferenciando-se, em muitos pontos, da tabela estratigráfica do Serviço Geológico e Mineralógico do Brasil, e também da estratigrafia apresentada na valiosa "Geologia do Brasil” (OLIVEIRA; LEONARDOS, 1943). 
A Classificação dos elementos da constituição geológica dos Estados do Paraná e Santa Catarina, até agora mantida, resumimos na nossa tabela estratigráfica $\mathrm{n}^{\mathrm{o}} 1$ :

TABELA 1 - Resumo da classificação estratigráfica, até agora mantida, dos Estados do PR e SC

\begin{tabular}{|c|c|c|c|c|}
\hline Era & $\begin{array}{c}\text { Período } \\
\text { geológico }\end{array}$ & $\begin{array}{l}\text { Nome do } \\
\text { sistema }\end{array}$ & Nome da série & $\begin{array}{c}\text { Nome do grupo, andar, formação } \\
\text { ou camada }\end{array}$ \\
\hline $\begin{array}{l}\text { Psicozóica } \\
\text { (idade do } \\
\text { homem) }\end{array}$ & $\begin{array}{l}\text { Quaternário } \\
\text { recente, } \\
\text { holoceno ou } \\
\text { alúvio } \\
\end{array}$ & - & sem nome & $\begin{array}{l}\text { depósitos fluviais, paludais e } \\
\text { lacustres; sedimentação litorânea- } \\
\text { praial; sambaquis }\end{array}$ \\
\hline \multirow[t]{3}{*}{$\begin{array}{c}\text { Neozóica } \\
\text { (Cenozóica) }\end{array}$} & $\begin{array}{l}\text { Quaternário } \\
\text { antigo, } \\
\text { pleistoceno ou } \\
\text { dilúvio }\end{array}$ & - & sem nome & $\begin{array}{c}\text { Quaternário de Curitiba, } \\
\text { formação Tamanduá } \\
\text { formação Cacimbas } \\
\text { cascalho pleistocênico }\end{array}$ \\
\hline & & & \multicolumn{2}{|c|}{ Discordância } \\
\hline & Terciário & - & - & - \\
\hline \multirow{4}{*}{ Mesozóica } & Cretáceo & \multicolumn{2}{|c|}{$\begin{array}{c}\text { série Bauru citada por Ch. W. } \\
\text { Washburne para Santa Catarina sem } \\
\text { maiores detalhes }\end{array}$} & - \\
\hline & Jurássico & \multicolumn{2}{|c|}{$\begin{array}{c}\text { falta na coluna para Paraná e Santa } \\
\text { Catarina; arenito Caiuá indicado } \\
\text { somente para São Paulo } \\
\end{array}$} & - \\
\hline & $\begin{array}{c}\text { Triássico } \\
\text { superior (rético) }\end{array}$ & \multirow{5}{*}{$\begin{array}{l}\text { sistema } \\
\text { Santa } \\
\text { Catarina } \\
\text { ou } \\
\text { sistema } \\
\text { Gonduânico }\end{array}$} & $\begin{array}{l}\text { série São Bento } \\
\text { Discord }\end{array}$ & $\begin{array}{c}\text { lavas da Serra Geral ou trapp do } \\
\text { Paraná } \\
\text { grupo Botucatu } \\
\text { arenito Botucatu } \\
\text { formação Pirambóia } \\
\text { ncia }\end{array}$ \\
\hline & $\begin{array}{c}\text { Triássico } \\
\text { (Keuper inferior, } \\
\text { andar cárnico) }\end{array}$ & & $\begin{array}{l}\text { Série Rio do Rasto } \\
\text { Discord }\end{array}$ & $\begin{array}{l}\text { grupo Rio do Rasto } \\
\text { formação Santa Maria } \\
\text { formação Serrinha } \\
\text { formação Terezina }\end{array}$ \\
\hline \multirow{7}{*}{ Paleozóica } & $\begin{array}{l}\text { Permiano } \\
\text { superior } \\
\text { P. inferior }\end{array}$ & & série Passa Dois & $\begin{array}{l}\text { grupo Estrada Nova } \\
\text { grupo Iratí }\end{array}$ \\
\hline & $\begin{array}{l}\text { Carbonífero } \\
\text { superior }\end{array}$ & & série Tubarão & $\begin{array}{l}\text { grupo Palermo } \\
\text { grupo Bonito }\end{array}$ \\
\hline & $\begin{array}{l}\text { Carbonífero } \\
\text { superior }\end{array}$ & & $\begin{array}{l}\text { série Itararé ou } \\
\text { série glacial } \\
\text { Discord }\end{array}$ & ncia \\
\hline & $\begin{array}{l}\text { Devoniano } \\
\text { (Devoniano } \\
\text { inferior) }\end{array}$ & $\begin{array}{c}\text { sistema } \\
\text { devoniano }\end{array}$ & série Paraná & $\begin{array}{l}\text { grupo Ponta Grossa } \\
\text { grupo Faxina - Furnas } \\
\text { formação Blumenau }\end{array}$ \\
\hline & Siluriano & - & - & Formação Anitápolis \\
\hline & & & \multicolumn{2}{|c|}{ Discordância } \\
\hline & Cambriano & - & $\begin{array}{l}\text { série Itajaí } \\
\text { série Ribeira } \\
\text { Discord }\end{array}$ & $\begin{array}{l}\text { formação Iporanga } \\
\text { formação Castro }\end{array}$ \\
\hline Proterozóica & $\begin{array}{l}\text { Pre-cambriano } \\
\text { ou algonquiano } \\
\text { (eo-algonquiano) }\end{array}$ & - & $\begin{array}{c}\text { série Açunguí e série } \\
\text { Brusque (= série de } \\
\text { Minas) } \\
\text { Discord }\end{array}$ & ncia \\
\hline $\begin{array}{l}\text { Arqueozóica } \\
\text { (Azóica) }\end{array}$ & $\begin{array}{c}\text { Arqueano } \\
\text { (complexo } \\
\text { fundamental) }\end{array}$ & $\begin{array}{l}\text { Complexo } \\
\text { brasileiro ou } \\
\text { complexo } \\
\text { cristalino } \\
\end{array}$ & ainda sem divisão & - \\
\hline
\end{tabular}


À tabela $n^{\circ} 1$ confrontamos a tabela $n^{\circ} 2$ com a classificação estratigráfica por nós apresentada, conforme nossas mais recentes pesquisas, como segue:

TABELA 2 - Nova divisão estratigráfica dos elementos da constituição geológica dos Estados do Paraná e Santa Catarina por Reinhard Maack, 1947 (vide fig. 16)

\begin{tabular}{|c|c|c|c|c|}
\hline Era & Período geológico & $\begin{array}{c}\text { Nome do } \\
\text { sistema }\end{array}$ & Nome da série & $\begin{array}{c}\text { Nome do grupo, andar, formação } \\
\text { ou camada } \\
\end{array}$ \\
\hline $\begin{array}{c}\text { Psicozóica } \\
\text { (idade do } \\
\text { homem) } \\
\end{array}$ & $\begin{array}{c}\text { Quaternário } \\
\text { recente, holoceno } \\
\text { ou alúvio } \\
\end{array}$ & - & sem nome & $\begin{array}{c}\text { depósitos fluviais, paludais e } \\
\text { lacustres; sedimentação litorânea- } \\
\text { praial; sambaquis }\end{array}$ \\
\hline \multirow[t]{3}{*}{$\begin{array}{l}\text { Neozóica } \\
\text { (Cenozóica) }\end{array}$} & \multirow[t]{2}{*}{$\begin{array}{c}\text { Quaternário } \\
\text { antigo, pleistoceno } \\
\text { ou dilúvio }\end{array}$} & \multirow[t]{2}{*}{ - } & sem nome & $\begin{array}{l}\text { Quaternário de Curitiba, } \\
\text { formação Tamanduá } \\
\text { formação Cacimbas } \\
\text { cascalho pleistocênico }\end{array}$ \\
\hline & & & \multicolumn{2}{|c|}{ Discordância } \\
\hline & Terciário & - & - & $\begin{array}{c}\text { no Paraná e Santa Catarina } \\
\text { movimentos tectônicos }\end{array}$ \\
\hline \multirow{9}{*}{ Mesozóica } & Cretáceo & - & - & $\begin{array}{c}\text { ainda não verificado no Paraná e } \\
\text { Santa Catarina } \\
\end{array}$ \\
\hline & \multirow{6}{*}{$\begin{array}{c}\text { Jurássico-liássico } \\
\text { Jurássico-liássico (?) } \\
\text { Triássico-rético (?) }\end{array}$} & \multirow{11}{*}{$\begin{array}{c}\text { sistema } \\
\text { Santa } \\
\text { Catarina } \\
\text { ou } \\
\text { sistema } \\
\text { Gonduânico }\end{array}$} & & arenito Caiuá \\
\hline & & & \multicolumn{2}{|c|}{ Discordância } \\
\hline & & & & lavas da Serra Geral \\
\hline & & & \multicolumn{2}{|c|}{ Discordância } \\
\hline & & & série São Bento & $\begin{array}{l}\text { grupo Botucatu } \\
\text { arenito Botucatu } \\
\text { formação Pirambóia }\end{array}$ \\
\hline & & & \multicolumn{2}{|c|}{ Discordância } \\
\hline & \multirow[t]{2}{*}{$\begin{array}{l}\text { Triássico (Keuper } \\
\text { inferior, andar } \\
\text { cárnico superior) }\end{array}$} & & - & $\begin{array}{c}\text { formação Santa Maria } \\
\text { (somente no Rio Grande do Sul, } \\
\text { falta no Paraná e Santa Catarina) }\end{array}$ \\
\hline & & & Discc & ncia \\
\hline \multirow{5}{*}{ Paleozóica } & $\begin{array}{c}\text { Permiano superior(?) } \\
\text { Permiano inferior (?) } \\
\text { Permiano inferior }\end{array}$ & & série Passa Dois & $\begin{array}{l}\text { grupo Rio do Rasto } \\
\text { camadas vermelhas ou } \\
\text { formação Poço Preto } \\
\text { formação Esperança } \\
\text { grupo Estrada Nova } \\
\text { camadas Terezina - Serrinha } \\
\text { formação Estrada Nova } \\
\text { s. str. ou camadas Serra Alta* } \\
\quad \text { grupo Iratí } \\
\end{array}$ \\
\hline & $\begin{array}{l}\text { Carbonífero } \\
\text { superior } \\
\text { Uraliano } \\
\text { Namuriano até } \\
\text { Moscoviano }\end{array}$ & & série Tubarão & $\begin{array}{l}\text { grupo Guatá* } \\
\text { camadas Palermo ou } \\
\text { formação postglacial } \\
\text { camadas Rio Bonito ou } \\
\text { formação carbonífera } \\
\quad \text { grupo Itararé ou formação } \\
\text { glacial }\end{array}$ \\
\hline & & & Discc & ncia \\
\hline & $\begin{array}{l}\text { Devoniano } \\
\text { (Devoniano } \\
\text { inferior) }\end{array}$ & $\begin{array}{c}\text { sistema } \\
\text { devoniano }\end{array}$ & $\begin{array}{c}\text { série dos Campos } \\
\text { Gerais }\end{array}$ & $\begin{array}{l}\text { grupo Barreiro** } \\
\text { grupo Santa Rosa } \\
\text { folhelhos São Domingos } \\
\text { arenito de Tibagí } \\
\text { folhelhos de Ponta Grossa } \\
\text { grupo Faxina - Furnas }\end{array}$ \\
\hline & & & Discc & ncia \\
\hline
\end{tabular}




\begin{tabular}{|c|c|c|c|c|}
\hline Era & Período geológico & $\begin{array}{l}\text { Nome do } \\
\text { sistema }\end{array}$ & Nome da série & $\begin{array}{l}\text { Nome do grupo, andar, formação } \\
\text { ou camada }\end{array}$ \\
\hline \multirow{6}{*}{ Paleozóica } & \multirow{2}{*}{$\begin{array}{c}\text { Siluriano } \\
\text { (gotlandiano) }\end{array}$} & \multirow{6}{*}{$\begin{array}{c}\text { sistema } \\
\text { eo-paleozóico }\end{array}$} & & $\begin{array}{c}\text { formação Iapó } \\
\text { formação Blumenau (?) }\end{array}$ \\
\hline & & & \multicolumn{2}{|c|}{ Discordância } \\
\hline & \multirow{4}{*}{$\begin{array}{l}\text { Ordoviciano (?) } \\
\text { Cambriano (?) }\end{array}$} & & série Itajaí & $\begin{array}{c}\text { formação Gaspar } \\
\text { conglomerado Baú } \\
\text { formação Ibirama }\end{array}$ \\
\hline & & & \multicolumn{2}{|c|}{ Discordância } \\
\hline & & & série Ribeira? & $\begin{array}{l}\text { formação Iporanga } \\
\text { formação Castro? }\end{array}$ \\
\hline & & & \multicolumn{2}{|c|}{ Discordância } \\
\hline Proterozóica & $\begin{array}{l}\text { Pre-cambriano } \\
\text { ou algonquiano } \\
\text { (eo-algonquiano) }\end{array}$ & $\begin{array}{c}\text { sistema } \\
\text { Espinhaço }\end{array}$ & $\begin{array}{c}\text { série Açunguí e série } \\
\text { Brusque (= série de } \\
\text { Minas) }\end{array}$ & 一 \\
\hline \multirow[t]{2}{*}{$\begin{array}{l}\text { Arqueozóica } \\
\text { (Azóica) }\end{array}$} & \multirow[t]{2}{*}{$\begin{array}{c}\text { Arqueano } \\
\text { (complexo } \\
\text { fundamental) }\end{array}$} & \multirow{2}{*}{$\begin{array}{l}\text { Complexo } \\
\text { brasileiro ou } \\
\text { complexo } \\
\text { cristalino }\end{array}$} & ainda sem divisão & - \\
\hline & & & \multicolumn{2}{|c|}{ Discordância } \\
\hline
\end{tabular}

As denominações assinaladas com * foram tomadas da tabela estratigráfica de Mackenzie Gordon Jr. (1947, p. 3).

** Vide nota em Grupo Barreiro, no item C.2 - O devoniano no Estado do Paraná.

\section{A - ERA ARQUEOZÓICA : O} ARQUEANO

$$
O A R Q U E A N O(\text { sinal }=\mathrm{ep} e)
$$

$\mathrm{O}$ arqueano abrange as rochas metamorfoseadas do complexo brasileiro com os granitos intrusivos gnaissificados de uma orogenia mais antiga, bem observável e caracterizada pelo tectonismo de intrusão, correspondendo ao diastrofismo brasílico de A. R. Lamego, e também as rochas de uma segunda era de dobramento e de intrusão, geralmente considerada como laurentiana. Os granitos postalgonquianos, ocorrendo no complexo arqueano, ainda não aparecem nos mapas geológicos separadamente. Tanto no Paraná como em Santa Catarina, a direção principal dos gnaisses é de N60-70 $\mathrm{E}$.

No Paraná, a zona de distribuição dos gnaisses e granitos mais antigos estende-se sobre a maior parte do litoral e sobre as regiões a leste do primeiro planalto até pouco a oeste de Curitiba. Em Santa Catarina, o arqueano predomina no litoral, desaparecendo sucessivamente no pedestal da Serra do Mar.

As rochas características são gnaisses catametamórficos e gnais-granitos (fig. 17, 18,
68 e 69). Até agora foram observados e estudados petrograficamente os seguintes tipos de gnaisses:

1. plagioclásio-gnais

2. biotita-gnais (fig. 69)

3. gnais lenticular e facoidal (Augen- und Flasergneis)

4. leptinitos e migmatitos

5. gnais-granitos

6. gnais-granito-pórfiros (fig. 68 e 69)

7. gnais-diorito

Entre os granitos encontra-se, como o mais antigo, um microclina-biotita-granitito e, da intrusão neoarqueana (laurentiana), um antigo hornblendabiotita-granito com ortoclásio e oligoclásio.

$\mathrm{Na}$ serra do Mar, o escudo gnáissico antigo foi penetrado por granitos huronianos mais recentes, causando também gnaissificação de rochas da série Açunguí (fig. 70). As rochas faneríticas, típicas destas intrusões, compõem-se de granititos, ricos em ortoclásios micropertíticos, com oligoclásio, quartzo e relativamente pouca biotita. Estes granititos formam as mais altas elevações da Serra do Mar como "Domgranite", tais como o Pico Paraná (1965 m, fig. 19) e o Pico Marumbi (1547 m, fig. 23). Especial atenção merece um stock de rocha afanítica, um quartzo- (riolito-) pórfiro, com grandes fenocristais de quartzos corroídos, com ortoclásio e oligoclásio- 
andesina, em uma massa fundamental, finamente granulada. Esta rocha eruptiva ácida é, aparentemente, mais recente do que os granititos penoqueanos e parece corresponder à idade geológica dos quartzo-pórfiros de Castro. Um perfil através da zona do Pico Paraná evidencia tanto $\mathrm{o}$ aspecto das linhas da superfície, como a constituição geológica da grande escarpa de falha (fig. 6).

\section{B - ERA PROTEROZÓICA : O EO- ALGONQUIANO}

\section{$O E O-A L G O N Q U I A N O(\operatorname{sinal}=\mathrm{Ip} e)$}

Como formações eo-algonquianas são reunidas, no Paraná, as rochas da série Açunguí e, em Santa Catarina, as da série Brusque. A zona principal de distribuição da série Açunguí abrange particularmente o primeiro planalto do Paraná, a oeste e ao norte de Curitiba, do vale do rio Ribeira até a escarpa devoniana. Ao norte da Serra Capivari Grande, a série Açunguí avança para o litoral, constituindo aí a região entre a ilha Cardoso e Guaraqueçaba. Grandes blocos de camadas gnaissificadas da série Açunguí ainda são encontrados entre o rio Cachoeira e a Serra São João, entre Morretes e Alexandra, na Serra da Prata, na parte sul da Serra do Mar e, finalmente, na parte sudoeste do primeiro planalto, entre Tijucas e São José dos Pinhais (fig. 70).

A série Brusque ocupa principalmente o vale do rio Itajaí-Mirim e é cortada pela cuesta entre Itajaí e Porto Belo. A oeste de Joinville e ao sul de Queçaba (ex-Terezópolis) jazem também camadas de rochas dobradas desta série.

As rochas sedimentares epi-metamórficas abrangem um grupo de xistos inferior e superior, - filitos, sericitaxistos, cloritaxistos, tacoxistos -, incluindo extensas lentes de calcáreos e calcáreos dolomíticos (fig. 74 a 79). Acrescem ainda camadas espessas de quartzitos puros e quartzitos com minérios de ferro sedimentares (itabiritos), engranzando-se muitas vezes facialmente com os filitos e calcáreos. Às rochas da série Açunguí também pertencem os gnaisses de injeção mais recentes, piezo-contactometamórficos, gnais-quartzitos verdadeiros, xisto micáceos de palhetas grosseiras e, finalmente, cloritaxistos do litoral, da Serra do Mar e do primeiro planalto, a oeste de Curitiba.
A espessura total da série Açunguí ainda não está precisamente determinada, mas, segundo as verificações realizadas até agora, importa no mínimo, 5000 a $7000 \mathrm{~m}$. A seqüência das camadas e a disposição das dobras serão elucidadas pelos esboços da figura 7 .

As rochas da série Açunguí refletem as direções de duas épocas de dobramento com intrusões ácidas, a saber:

1) A orogenia huroniana com direção geral de $\mathrm{N} 40-50^{\circ} \mathrm{E}$ e, na região limítrofe com o escudo gnáissico antigo, de $\mathrm{N} 60-70^{\circ} \mathrm{E}$;

2) A fase taconiana da orogenia caledoniana com direção predominante de $\mathrm{N} 20-30^{\circ} \mathrm{E}$.

Os granitos huronianos (sinal $=$ pei, fig. 71 a 73 ) com extensas áreas de pórfiro-granitos grosseiros (fig. 72), granito-pórfiros, pegmatitos e veios de aplito mostram ortoclásios micropertíticos e oligoclásio, como feldspatos, com quartzo e biotita. Os granitos caledonianos são caracterizados por ortoclásio, albita e oligoclásio com quartzo, biotita e hornblenda, ocorrendo freqüentemente hornblendagranititos puros com pouco quartzo. São encontrados, como rochas efusivas, quartzo-pórfiros $($ sinal $=$ PAv $)$ na região de Castro - Piraí-Mirim e na Serra do Mar (Caratuba) no Paraná; em Aquidaban, no Morro Cambirela, perto de Imbituba no litoral e também na ilha Santa Catarina.

Fósseis ainda não foram verificados nos sedimentos das séries Açunguí e Brusque.

\section{C - ERA PALEOZÓICA}

Tanto no Paraná, como em Santa Catarina, ocorrem depósitos pre-devonianos em discordância nítida com as camadas das séries Açunguí e Brusque. Para o Paraná, já Othon Henry Leonardos (OLIVEIRA; LEONARDOS, 1943, p. 206) menciona conglomerados de caráter glacial do rio Pardo inferior que se prolongariam Paraná a dentro, com extensão ainda não conhecida. $\mathrm{O}$ referido autor denomina estas camadas formação Iporanga, incluindo-as na série Ribeira, fazendo notar (OLIVEIRA; LEONARDOS, 1943, p. 205) que estes depósitos são mais antigos do que a série Bambuí em Minas e que poderiam corresponder à série Itacolomí (neo-algonquiano) ou à série de Lavras (cambriano ?).

Durante nossas pesquisas na região devoniana do Paraná verificamos a existência de restos de camadas semelhantes, de caráter glacial e lacustre (depósitos de drift), na base do arenito das Furnas. Sobre este 
fato apresentamos ao $2^{\circ}$ Congresso PanAmericano de Engenharia de Minas e Geologia (MAACK, 1946b), uma tese referente à nova estratigrafia do devoniano do Paraná. Não pode ser decidido, em face dos estudos comparativos incompletos e dos conhecimentos insuficientes sobre a série Ribeira, se estas camadas de caráter flúvio-glacial, por nós denominadas formação Iapó, são idênticas aos conglomerados de aspecto glacial da série Ribeira. Contudo, é possível que os arcósios com restos de granitos, mencionados para a Serra Sant'Ana por OLIVEIRA (1927, A) denominados, geralmente, com outras ocorrências, de formação Castro, correspondam à série Ribeira. Os arcósios da Formação Castro ainda foram atravessados pelos quartzo-pórfiros, sendo motivados os depósitos sub-aquáticos na escarpa devoniana a oeste de Piraí-Mirim por cinzas vulcânicas e produtos de desagregação dos quartzo-pórfiros. O horizonte mais inferior dos depósitos flúvio-glaciais na Serra São Joaquim, a oeste de Castro, também ainda foi influenciado pela última fase vulcânica, em forma de deposição de brechas de quartzopórfiros. Mas o horizonte flúvio-glacial superior, cinzento-azulado, é completamente desprovido destes elementos. Os dois horizontes cortam discordante e horizontalmente os quartzopórfiros e as camadas da série Açunguí, mostrando assim que são mais recentes do que a orogenia caledoniano-taconiana.

Em Santa Catarina, os depósitos postalgonquianos e pre-devonianos ocupam vasta área do vale do Itajaí-Açú. $\mathrm{O}$ afloramento extremo sul destas camadas encontramos na região das nascentes do rio Capivari, em São Bonifácio. Num trabalho anterior denominamos estes sedimentos de horizonte de xistos mais recente do siluriano (MAACK, 1937, B, p. 1112), visto que naquela época não se conheciam suas relações com a série Itajaí. Baseados na determinação de fósseis por Carlota Joaquina Maury de um polychaeta do siluriano superior, Oliveirania santacatharinae, que procederia dos ardósios escuros de Anitápolis, denominamos o horizonte de xistos mais recente camadas Anitápolis. Neste ínterim, porém, verificamos, por novas pesquisas no próprio lugar, que o horizonte de xistos mais recente é idêntico à série Itajaí e que os ardósios escuros de Anitápolis, na realidade, representam varvitos escuros do grupo Itararé, fracamente cozidos pelo contato com diabásio.

\section{C.1 - Formação pre-devonianas do cambriano até o siluriano $($ sinal $=S$ )}

No esboço que acompanha a revisão do mapa geológico da América do Sul, todas as formações pre-devonianas acima da série Açunguí foram reunidas sob o sinal do siluriano $(\mathrm{S})$, em vista de que a idade geológica e a conexão dos diferentes depósitos, no Paraná e Santa Catarina, ainda não são conhecidas suficientemente. Apresentamos a tabela estratigráfica seguinte das diversas formações predevonianas no Paraná e Santa Catarina:

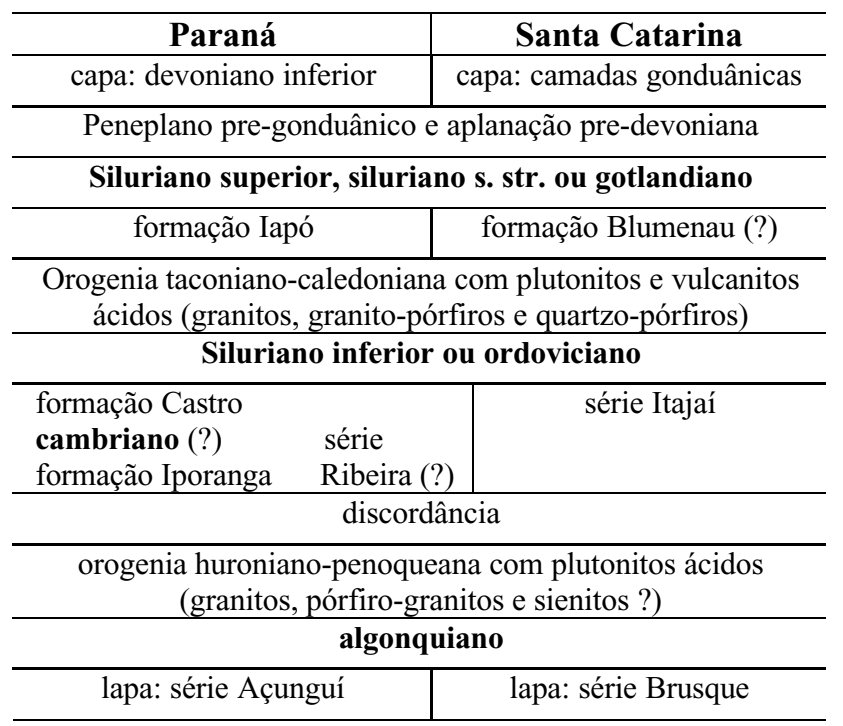

\section{3) A série Ribeira no Paraná}

Esta série, constituída por filitos, ardósios e tilito ?, foi criada por Othon Henry Leonardos pela ocorrência no vale do rio Ribeira, em Iporanga, reunindo nesta as formaçoes Iporanga e Castro (OLIVEIRA; LEONARDOS, 1943).

\section{a) A formação Iporanga}

As rochas da série Ribeira com conglomerados, para os quais $\mathrm{O}$. H. Leonardos indica origem glacial, avançam para o Paraná na altitude da foz do rio Pardo. Sobre a extensão e constituição desta formação, na região do Paraná, faltam quaisquer pesquisas. O. H. Leonardos menciona que Djalma Guimarães, baseado em estudos microscópicos e químicos, opinou que o conglomerado da série Ribeira, tratado como de origem glacial, corresponde 
ao conglomerado Sopa da série Lavras, de Minas Gerais (OLIVEIRA; LEONARDOS, 1943 , p. 204)*. Leonardos, por este motivo, atribui a estas camadas a idade neo-algonquiana (?) até cambriana (?).

\section{b) A formação Castro}

Os arcósios, afetados ainda pelos quartzopórfiros na região de Castro e observados pela primeira vez por Euzébio Paulo de Oliveira na Serra Sant'Ana, Othon H. Leonardos julga provável poder separá-los da série Açunguí, anexando-os à série Ribeira. Nós, porém, reconhecemos nos arcósios de Castro restos de erosão de depósitos sub-aquáticos sobre granitos caledoniano-taconianos, depósitos que revelam, provavelmente, ainda relações com os quartzopórfiros de Castro, como outros depósitos a oeste de Piraí-Mirim sob o arenito das Furnas. Tendo os quartzo-pórfiros cortado os arcósios, estes são um pouco mais antigos do que as camadas horizontais na base do arenito das Furnas, não mais atingidas pelo dobramento taconiano. Este o motivo que nos leva a reconhecer nos arcósios de Castro restos de erosão do ordoviciano que parecem corresponder à série Itajaí, em Santa Catarina. Como ainda não tivemos oportunidade de estudar os afloramentos da série Ribeira, não podemos tomar atitude quanto à existência e ao caráter litológico desta série. Neste particular baseamo-nos exclusivamente nas informações de Othon H. Leonardos.

\section{4) A série Itajaí em Santa Catarina}

\footnotetext{
* A idade geológica d série glacial de Lavras foi discutida em Belo Horizonte, após realização da excursão à Diamantina, dirigida pelo Prof. Dr. Luciano Jacques de Moraes e promovida pelo $2^{\circ}$ Congresso Pan-Americano de Engenharia de Minas e Geologia, em 1946. Nesta ocasião, diversos geólogos apontaram analogias entre estas camadas da série de Lavras e os sedimentos glaciais carboníferos do Brasil Meridional. Em seu trabalho "Metalogenese nas formações Arqueo-Proterozóicas do Brasil" (Belo Horizonte, 1947), Djalma Guimarães indica igualmente para a série de Lavras "(quadro 2 ,p. 18) "erosão e sedimentação glacial" no permo-carbonífero.

Relativamente ao caráter meso-metamórfico da série de Lavras chamamos a atenção para os fenômenos idênticos nas camadas glaciais carboníferas do grupo Itararé, na Serra São Miguel, zona limítrofe entre Paraná e Santa Catarina (vide foto 117 e p. 92).
}

A zona de distribuição principal da série Itajaí encontra-se em ambos os lados do rio Itajaí-Açú, entre Gaspar, Subida e Ibirama (ex-Hamônia). Entre Subida e Rio do Sul, as rochas da série Itajaí terminam ao contato com granitos caledonianotaconianos, no $\mathrm{km} \mathrm{28}$. No Morro Pelado e em Aquidaban, estas camadas também são cortadas por quartzo-pórfiros. Ao norte do vale do Itajaí-Açú, ocorrem rochas da série Itajaí ainda ao noroeste de Arrozeira, no vale do rio Cedro. A extensão mais para norte continua desconhecida.

Segundo nossas verificações, a série Itajaí é formada por uma seqüência de quartzitos, finamente laminados, arcósios pretos e duros (fig. 80) e filitos de uma zona epi-metamórfica. A oeste, as camadas apresentam-se abruptamente erguidas; na parte leste da distribuição da série Itajaí observa-se disposição suavemente ondulada e, por vezes, quase horizontal, zona onde afloram arenitos vermelho-violáceos, em bancos, fracamente metamorfoseados, conglomerados em parte friáveis e parcialmente silicificados (fig. 81 e 82), como também folhelhos vermelhos, areno-argilosos, finamente laminados. Muitas vezes, estas camadas denotam suave inclinação para oeste ou jazem ainda horizontalmente (fig. 82 e 83). As camadas dirigemse para $\mathrm{N} 10-20^{\circ} \mathrm{E}$, com um mergulho de $60-75^{\circ}$ para $\mathrm{E}$, entre os $\mathrm{km} 28$ e 29 da estrada Rio do Sul Subida. Uma pequena falha atravessa a série Itajaí, no $\mathrm{km} 28$, rumo $\mathrm{N} 340^{\circ} \mathrm{W}$. Superiormente, a série Itajaí é limitada por um conglomerado de 300-400 m de espessura, o conglomerado Baú. Em várias localidades a oeste de Indaial, afloram intrusões graníticas na série Itajaí. Os conglomerados da série Itajaí antigamente eram tidos como depósitos glaciais até que Ruy Osório de Freitas verificou a origem flúvio-piemôntica (FREITAS, 1945). Nós denominamos as camadas da lapa, fortemente dobradas, da região de distribuição a oeste, com os arcósios escuros de Subida, como formação Ibirama, enquanto que a seqüência da capa, pouco dobrada, na região a leste com o arenito de Blumenau e o conglomerado Baú designamos de formação Gaspar. Pelas observações até agora realizadas e pelas nossas pesquisas efetuadas em 1947 apresentamos, até levantamentos mais detalhados, a seguinte classificação: 


\begin{tabular}{|l|l|}
\hline capa: em parte, camadas gonduânicas, localmente o \\
conglomerado de Blumenau.
\end{tabular}

Até o presente, não foram encontrados fósseis na série Itajaí; assim não se pode determinar com certeza a idade geológica. Devem ser admitidos o cambriano e siluriano inferior, ou o ordoviciano respectivamente. Todavia, uma limitação superior é formada pelas intrusões caledoniano-taconianas e inferiormente existe um ponto de apoio pela discordância com as dobras huronianas da série Brusque. Estas dobras mais antigas da série Brusque já tinham sofrido, até que se processou o depósito da série Itajaí, ainda foram sujeitas ao dobramento caledoniano-taconiano, excluí-se, como idade geológica, o siluriano superior, o siluriano s. str., ou gotlandiano respectivamente. Portanto, como idade geológica admitimos o cambriano e ordoviciano, considerando o ordoviciano mais provável em vista da erosão das dobras huronianas.

\section{5) $A$ orogenia caledoniano-taconiana $e$ suas rochas eruptivas $($ sinal $=P A v)$}

Para evitar dúvidas, seja esclarecido que consideramos como era da orogenia caledoniana todos os fenômenos orogenéticos - dobramentos e intrusões -, durante o percurso do ordoviciano e gotlandiano. Com E. Kayser,H. Stille, Rueger, W. Behrmann e outros, dividimos os fenômenos desta era de orogenia nas seguintes quatro fases:

\section{Período Fase de dobramento}

Siluriano superior ou No fim: eriana (erisch)

siluriano s. str. = Ardeniana $(\operatorname{ardennisch})$ era da

gotlandiano Taconiana (takonisch) orogenia

Siluriano inferior $=$ Sardiana (

ordoviciano

As intrusões ácidas da era caledoniana alcançaram no Paraná e Santa Catarina ainda a formação Castro e a série Itajaí, para as quais consideramos o ordoviciano como idade geológica. De outro lado, camadas pre-devonianas (gotlandianas) na base do arenito das Furnas não foram mais afetadas pelo diastrofismo e jazem horizontalmente. Sobre estas camadas horizontais já transpassa um paleoplano pre-devoniano. Disto ressalta que durante as últimas duas fases do diatrofismo caledoniano, das fases ardeniana e eriana, se haviam extinguido os movimentos orogênicos no Brasil Meridional. As relações estratigráficas dos plutonitos e vulcanitos, especialmente dos quartzo-pórfiros de Castro, revelam deste modo, como idade geológica da orogenia, a fase taconiana que se deu entre o fim do ordoviciano e o início do gotlandiano. Esta conclusão fica confirmada pelo fato de que os sedimentos horizontais na base do arenito das Furnas contêm, na parte inferior, ainda cinzas vulcânicas e brechas de quartzo-pórfiro de Castro.

As direções do dobramento da fase taconiana, percorrem, no Paraná e Santa Catarina, no rumo N15 a $30^{\circ} \mathrm{E}$, predominando a orientação $\mathrm{N} 20^{\circ} \mathrm{E}$. Entre os granitos mais recentes das intrusões desta orogenia são típicos hornblenda-biotita-oligoclásio, revelando relações genéticas com as rochas efusivas da região Castro - Piraí-Mirim. Como rochas vulcânicas características observam-se quartzo-pórfiros e riolito-pórfiros, os quais afloram no Paraná na região de Castro - Piraí-Mirim e na Serra do Mar e em Santa Catarina em Aquidaban, no Morro Cambirela, em Imbituba e na Ilha Santa Catarina.

\section{6) A formação Iapó}

As camadas desta formação foram descritas, pela primeira vez, pelo autor em 1946 (MAACK, 1946b). Elas se encontram na escarpa devoniana, a oeste de Castro, discordantemente sobre as rochas da série Açunguí, fortemente dobradas, e em disposição não perturbada e horizontal sobre os vulcanitos 
caledoniano-taconianos, ou quartzo-pórfiros de Castro respectivamente. Trata-se de dois bancos de camadas depositadas sub-aquaticamente, revelando abundante material glacial de drift, de modo que, à primeira vista, lembram tilito (fig. 85). O banco inferior de camadas avermelhadas com 14,5 m de espessura contém, além do material glacial de drift - quartzitos coloridos, granitos, gnaisses e filitos -, de tamanho variável de pedregulho até blocos, também brechas vulcânicas dos quartzo-pórfiros próximos. O banco azul-acinzentado superior, com espessura de 1,5 a $2 \mathrm{~m}$, é isento de todo e qualquer material vulcânico proveniente dos quartzo-pórfiros da lapa. Este banco é cortado pelo paleoplano pre-devoniano, transgredindo sobre ele o arenito das Furnas eo-devoniano.

Das nossas observações ressalta que os sedimentos vermelho-castanhos inferiores foram depositados no limite entre o ordoviciano e siluriano s. str., após findos os movimentos orogênicos, porém ainda abastecidos com brechas e cinzas vulcânicas. Sedimentos lacustres com cinzas vulcânicas e material de decomposição, de coloração marronavermelhada dos quartzo-pórfiros, são encontrados também na base do arenito das Furnas, a oeste de Piraí-Mirim. Estas camadas até agora não estão bem estudadas.

O banco flúvio-glacial superior, azulacinzentado, na Serra São Joaquim, foi depositado após o término dos movimentos orogênicos e das atividades vulcânicas taconianas. Sendo os bancos de camadas limitados superiormente pelo paleoplano predevoniano e o arenito das Furnas eo-devoniano, os sedimentos de drift glacial da formação Iapó podem ser considerados como restos de erosão do siluriano-gotlandiano (fig. 8 e 84 ).

\section{7) A formação Blumenau}

Os conglomerados na capa das rochas da série Itajaí, nas elevações das vizinhanças de Blumenau, na literatura geológica são denominados formação Blumenau, (FREITAS, 1945) e (OLIVEIRA; LEONARDOS, 1943). Na "Geologia do Brasil" (OLIVEIRA; LEONARDOS, 1943) esta formação é mencionada como devoniana; entretanto, a nosso ver, não existem provas para tal opinião. Os conglomerados, constituídos de material de decomposição da série Itajaí, podem ter sido depositados também no siluriano, correspondendo assim à formação Iapó no Paraná. Fato é que a série Itajaí na lapa sofreu ainda o dobramento caledoniano-taconiano, enquanto que a formação Blumenau, como a formação Iapó no Paraná, não foi atingida pela ação da orogenia caledoniana. Além disso, deve-se considerar que a transgressão devoniana não mais atingiu as zonas orientais no atual litoral de Santa Catarina. O limite oriental extremo da transgressão devoniana percorre cerca de $50 \mathrm{~km}$ a oeste da Serra do Mar sobre o planalto do Paraná. Sobre este limite de transgressão, desviando já no Paraná para SW, transpassam as camadas gonduânicas diretamente sobre o complexo cristalino. No Brasil Meridional, verificou-se, de um modo geral, entre o devoniano inferior e o carbonífero superior, uma denudação importante que, aliás, é evidenciada pela formação do paleoplano pre-gonduânico, nivelando também o complexo cristalino. Do precedente concluí-se que a deposição de conglomerados devonianos no litoral de Santa Catarina é menos provável do que uma sedimentação siluriana, restos da qual ainda existem em várias localidades, como, por exemplo, no Paraná sob o arenito das Furnas. Apesar destes fatos, continua problemática a idade geológica da formação Blumenau.

\section{C.2 - O devoniano no Estado do Paraná $(\operatorname{sinal}=\mathbf{D})$}

Para o sistema devoniano no Estado do Paraná apresentamos uma nova classificação (MAACK, 1946b). As antigas denominações série Paraná ou série Paraná - Tibagí foram substituídas pelo nome mais característico "Série dos Campos Gerais". A denominação Paraná, já há muito vem a ser usada na Argentina para o "andar Paraná", enquanto que o termo Tibagí foi aplicado para um banco de camadas ou uma lente dos sedimentos devonianos. A nova classificação do devoniano paranaense é demonstrada pela tabela seguinte: 


\begin{tabular}{|c|c|}
\hline \multicolumn{2}{|c|}{ Discordância } \\
\hline \multicolumn{2}{|c|}{ Série dos Campos Gerais } \\
\hline \multicolumn{2}{|c|}{ devoniano inferior } \\
\hline \multicolumn{2}{|c|}{ c) Grupo Barreiro* } \\
\hline 6. arenitos de Barreiro .. & ca. $130-215 \mathrm{~m}$ \\
\hline \multicolumn{2}{|l|}{ b) Grupo Santa Rosa } \\
\hline 5. folhelhos de São Domingos ... & ca. $30-90 \mathrm{~m}$ \\
\hline 4. arenito de Tibagí & ca. $18-20 \mathrm{~m}$ \\
\hline 3. folhelhos de Ponta Grossa & ca. $84-90 \mathrm{~m}$ \\
\hline \multicolumn{2}{|l|}{ a) Grupo Faxina - Furnas } \\
\hline 2. arenito das Furnas . & ca. $100-150 \mathrm{~m}$ \\
\hline 1. conglomerado basal & ca. $1-2 \mathrm{~m}$ \\
\hline TOTAL .................................... & ca. $363-567 \mathrm{~m}$ \\
\hline Em média ....................... & ca. $465 \mathrm{~m}$ \\
\hline \multicolumn{2}{|c|}{ Discordância } \\
\hline \multicolumn{2}{|c|}{ lapa: depósitos de drift glacial-lacustre como restos de erosão. } \\
\hline \multicolumn{2}{|c|}{ Discordância } \\
\hline \multicolumn{2}{|c|}{$\begin{array}{l}\text { Quartzo-pórfiros de Castro, granito-pórfiros, granitos e xistos } \\
\text { metamórficos da série Açunguí }\end{array}$} \\
\hline
\end{tabular}

O devoniano circunda o complexo cristalino paranaense, quase num ângulo reto, formando um arco cuja abertura é voltada para leste. Ocupa uma superfície de $6252 \mathrm{~km}^{2}$, dos quais $4290 \mathrm{~km}^{2}$ cabem ao arenito das Furnas (fig. $84 \mathrm{e}$ 86), $1836 \mathrm{~km}^{2}$ aos folhelhos do grupo Santa Rosa (fig. 87 a 89) e $125 \mathrm{~km}^{2}$ aos arenitos Barreiro (fig. 90).

No Brasil Meridional, os extensos movimentos orogênicos com suas intrusões ácidas são limitados pelos sedimentos devonianos. Todas as camadas da capa sedimentar, a partir do siluriano e devoniano, jazem quase horizontalmente, sendo causado seu suave mergulho para SW e W pela inflexão da bacia do Paraná, como conseqüência do peso do potente derrame eruptivo básico. Algumas falhas que cortam as camadas devonianas, como, por exemplo, em Jaguariaíva na direção $\mathrm{N} 28^{\circ} \mathrm{E}$ com uma diferença de nível de $180 \mathrm{~m}$, ou em Itaiacoca e Serradinha rumo $\mathrm{N} 50^{\circ} \mathrm{W}$ com $80 \mathrm{~m}$ de diferença de nível e em Ponta Grossa no sentido $\mathrm{N} 45^{\circ} \mathrm{W}$, também com $80 \mathrm{~m}$ de diferença de nível, são relacionadas com as fendas de tração e com as erupções das lavas básicas neoaté post-triássicas.

Dos três grupos principais da série dos Campos Gerais, o de Santa Rosa é particularmente rico em fósseis. A fauna marinha dos folhelhos de Ponta Grossa - com trilobitas, braquiópodos, lamelibrânquios, cefalópodos, pterópodos, asteróideos e anelídeos - e os bancos de Spirifer do arenito de Tibagí correspondem ao devoniano mais inferior, provavelmente ao grupo Helderberg da América do Norte, revelando relações faunísticas particularmente com as ilhas
Falkland e com as camadas de Bokkefeld da África do Sul. Porém, também o arenito das Furnas e os arenitos Barreiro não carecem totalmente de fósseis. Nestes arenitos foi verificada a existência de restos de vermes (LANGE, 1942) e braquiópodos (MAACK, 1946ab). Os principais lugares fossilíferos do devoniano encontram-se nas vizinhanças de Ponta Grossa, nos vales dos rios Caniú e Caniuzinho, na região de Tibagi, em Lambedor, no vale do rio Guaricanga e em Jaguariaíva.

\section{C.3 - O sistema Santa Catarina ou as camadas gonduânicas}

Sob a denominação de camadas gonduânicas dos continentes meridionais entendem-se todos os depósitos, desde o carbonífero até o triássico, inclusive o espesso lençol eruptivo básico do rético ou liássico. WHITE (1908) reuniu as camadas gonduânicas no Brasil Meridional sob a denominação de sistema Santa Catarina. A primitiva classificação sofreu várias modificações; assim, Euzébio Paulo de Oliveira separou as camadas glaciais como série Itararé da série Tubarão (OLIVEIRA, 1927); a série Rio do Rasto apareceu, a princípio, como triássica (WHITE, 1908), depois como permiana superior (OLIVEIRA, 1918) e, mais tarde, de novo como do triássico superior.

As pesquisas recentes revelaram que os depósitos glaciais da série Itararé são tão intimamente engranzados com as camadas da série Tubarão, de modo que não podem ser separados em duas séries independentes (MAACK, 1946a).

Relativamente às camadas vermelhas Rio do Rasto foi verificado que não são idênticas às camadas Santa Maria e que estas se situam mais alto no perfil estratigráfico.

As camadas Estrada Nova com seu banco calcáreo limitante, o calcáreo ou grupo Rocinha, que se achavam totalmente incluídas na série Passa Dois do permiano superior, posteriormente foram divididas em Estrada Nova inferior e Estrada Nova superior.

As camadas inferiores continuaram no permiano superior, enquanto que as superiores foram colocadas no triássico. Finalmente, os horizontes calcáreos foram separados da série Passa Dois e, em virtude da determinação de fósseis por F. R. Reed (COWPER REED, 1928) ligados à série Rio do Rasto como grupo Terezina. Para os horizontes fossilíferos um pouco superiores da mesma seqüência de camadas, dos quais $K$. Holdhaus 
(HOLDHAUS, exclusivamente 1919)

determinou introduzida a denominação grupo Serrinha, apesar de se tratar de camadas com o mesmo conteúdo fossilífero e idênticas ao grupo Terezina.

Nas camadas vermelhas da série Rio do Rasto, que foram equiparadas, ou confundidas respectivamente, com as camadas Santa Maria com sáurios, do Rio Grande do Sul, são encontrados em Valões e Poço Preto em Santa Catarina, os filópodos Estheria e Leaia, determinados por F. R. Cowper Reed (COWPER REED, 1929; 1930). Estas camadas vermelhas contêm Estheria em toda sua espessura até imediatamente abaixo do arenito Botucatu. Quanto às camadas de Valões e Poço Preto com filópodos, não se tratam de horizontes da formação Estrada Nova s. str., como anteriormente foi indicado, mas de sedimentos situados acima dos horizontes de lamelibrânquios de Cowper Reed e Holdhaus. Nos próprios horizontes de lamelibrânquios, porém, também ocorre a fauna de filópodos descritos por F. R. Cowper Reed. Nestas verificações baseia-se a nova classificação das camadas entre o permiano e triássico (fig. 16).

\section{C.4 - O carbonífero no Paraná e Santa Catarina, ou a série Tubarão respectivamente}

NOTA: Grupo Barreiro - Durante a impressão deste trabalho, tivemos conhecimento de uma comunicação (Programa 1947, Annual Meetings, Ottawa - Ontário, p. 1173), na qual Kenneth E. Caster e Setembrino Petri recentemente incluem no carbonífero os arenitos Barreiro, como membro do grupo glacial Itararé. Relativamente à opinião de que os arenitos Barreiro representem sedimentos glaciais do grupo Itararé, já nos referimos nas nossas Notas Preliminares sobre uma nova estratigrafia do devoniano (MAACK, 1946b). Contra tal concepção atestam a homogeneidade dos pedregulhos e seixos sem estrias, quase que exclusivamente constituídos por quartzo e quartzitos, e as formas bem arredondadas, de caráter fluvial, do material dos bancos conglomeráticos, no seio dos arenitos Barreiro. Os pedregulhos e seixos, a deposição em bancos e chapas, como também a freqüente estrutura discordante diagonal (falsa estratificação) e entrecruzada correspondem ao arenito das Furnas. De nenhum modo, os arenitos Barreiro, com espessura até $200 \mathrm{~m}$, pelo seu caráter litológico geral e pelos seus bancos homogêneos de pedregulho, podem ser idênticos ao material glacial heterogêneo e ao aspecto geral do arenito de Vila Velha.
No Paraná e Santa Catarina, o carbonífero é representado apenas por sedimentos do carbonífero superior, considerados antigamente como do permiano inferior. Os fósseis marinhos da formação glacial do grupo Itararé e a associação florística que resulta do conteúdo fossilífero da formação Rio Bonito com uma mistura entre elementos do carbonífero inferior e da mais antiga flora de Glossopteris, revelam com a maior probabilidade o carbonífero superior. A flora carbonífera do Paraná e Santa Catarina exibe muitos elementos que atingem apenas o permiano inferior. A mescla de elementos da flora de Rhacopteris e Gangamopteris com Glossopteris, Phylloteca, Schizoneura, Noeggerathiopsis, Gondwanidium (Neuropteridium), Sphenophyllum, Lycopodiopsis e Lepidodendron na flora gonduânica sul-americana da formação Rio Bonito caracteriza a mais antiga flora gonduânica que se desenvolveu no carbonífero superior médio e que, quanto à idade, talvez corresponda à flora do carbonífero produtivo do hemisfério setentrional, entre o westfaliano e stefaniano. No decorrer entre o devoniano médio e o carbonífero inferior foi formado o peneplano pre-gonduânico. Sobre este paleoplano que, na região do Paraná, mergulho como plano de declive para $\mathrm{W}$ e SW, deslizaram as massas do inlandsis gonduânico procedentes de E.

\section{a) A formação glacial ou grupo Itararé $($ sinal $=$ Cge Cm)}

O grupo Itararé abrange os depósitos continentalglaciais e os glacial-marinhos da glaciação

Igualmente chamamos a atenção para o fato de não ser estranho encontrar-se, eventualmente, material de drift nas camadas devonianas, uma vez que na base do arenito das Furnas são observados sedimentos pre-devonianos de clima frio, ocorrendo também material glacial de drift heterogeno.

De outro lado, é possível que os arenitos da Serra Montenegro representem realmente uma chapa de arenito das Furnas, elevada a mais de $200 \mathrm{~m}$ sobre o nível dos folhelhos de Ponta Grossa. Esta possibilidade já foi por nósconsiderada, em vista do caráter de "horst" desta serra, possibilidade esta que já discutimos com Kenneth E. Caster.

Observa-se no lado N da Serra Montenegro um mergulho da chapa de arenito abaixo das camadas glaciais. Nos vales do flanco W, cerca de 75 a $150 \mathrm{~m}$ abaixo dos arenitos, afloram folhelhos de Ponta Grossa (fig. 87). Uma linha de falha até o momento não pode ser verificada no limite entre estes folhelhos e arenitos. Na parte S da serra tem-se impressão de uma chapa de arenito das Furnas, tectonicamente elevada, inclinando para N. No platô da serra não aparecem mais os folhelhos de Ponta Grossa. Segundo estas verificações existe a possibilidade - sem dispor de provas concretas - de que a Serra Montenegro represente uma chapa de arenito das Furnas, tectonicamente elevada na parte sul. 
gonduânica. Segundo nossas pesquisas mais recentes, a glaciação no Brasil Meridional iniciou-se possivelmente no namuriano, prolongando-se para aquém do andar moscoviano do carbonífero superior. Estas camadas jazem sobre os depósitos devonianos em leve discordância angular de 15-18 minutos de arco. Os sedimentos continental-glaciais são constituídos por arenitos flúvio-glaciais e glacial-lacustres (fig. 34, 35, 91 a 95), argilas glaciais - varvitos e peloditos -, tilitos (fig. 93), conglomerados glaciais lavados e por arenitos eólicos e loess (MAACK, 1946a).

$\mathrm{Na}$ região do norte do Paraná, podem ser verificados quatro a cinco avanços principais do gelo e na região sul do Paraná, quatro avanços com três a quatro fases interestadiais frias. Nem pela seqüência, nem pela espessura da sedimentação podem ser comprovadas épocas interglaciais mais quentes e mais extensas.

No último terço da glaciação, o mar transgrediu até a linha Mafra - Guaraúna (ex-Valinhos) Ipiranga, substituindo os dois últimos horizontes de tilito desta zona por conglomerados de drift. Os sedimentos marinhos são ricos em fósseis. No Paraná, foram observados até agora três horizontes fossilíferos distintos entre os conglomerados de drift e em sedimentos neríticos azul-acinzentado-escuros (maiores detalhes em MAACK, 1946a). Denominamos:

- o fácies continental-glacial formação Palmira e

- o fácies glacial-marinho formação Taió.

No Paraná, a espessura de 316 a 367 m corresponde aos depósitos continental-glaciais (sinal $=\mathrm{Cg}$ ) e a de 65 a $103 \mathrm{~m}$ às camadas glacial-marinhas $($ sinal $=\mathrm{Cm})$. Em Santa Catarina, predominam os sedimentos glaciallacustres e glacial-marinhos. Naquele Estado são verificados apenas dois horizontes de tilito, sendo o conteúdo fossilífero distribuído através da espessura total de mais de $300 \mathrm{~m}$ dos sedimentos glacial-marinhos.

\section{b) As camadas com carvão ou formação Rio Bonito $($ sinal $=C c)$}

As camadas com carvão começam, no Paraná, gradativamente com arenitos, incluindo restos vegetais, e camadas argilosas escuras, ricas em fósseis da flora Glossopteris, engranzadas na base, regionalmente, com as camadas glaciais. $\mathrm{Na}$ região sul de Santa Catarina, como no Paraná, os sedimentos com carvão da formação Rio Bonito, desenvolvem-se gradativamente das camadas glaciais do grupo Itararé com o conglomerado de Orleans, com varvitos e arenitos flúvio-glaciais (fig. 94 e 95). As camadas glaciais possuem, no sul de Santa Catarina, apenas a espessura de $52 \mathrm{~m}$. Sendo a série Tubarão, em virtude da sua importância econômica, tratada mais detalhadamente que qualquer outra formação, na literatura geológica referente ao Brasil Meridional, pormenores especiais aqui não são necessários.

$\mathrm{Na}$ constituição da formação tomam parte especialmente arenitos, siltitos e folhelhos arenoargilosos que incluem cinco camadas, pouco espessas, de carvão, a saber:

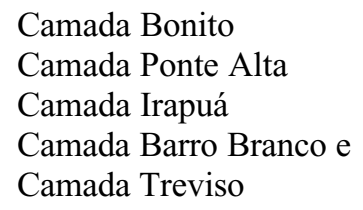

As camadas Barro Branco e Bonito são as de maior importância econômica. Na camada Barro Branco, o autor encontrou, na mina Próspera em Criciúma, ao lado dos fósseis comuns da flora gonduânica, como exemplar mais importante, o Lycopodiopsis derbyi Renault (fig. 16). A possança da formação Rio Bonito varia entre 80 e 150 m. Ocupa particularmente a parte sul do litoral catarinense, entre Orleans, Criciúma e Lauro Mueller, encontrando-se sobre camadas glaciais no perfil Barracão - Bom Retiro, na latitude da chapada Boa Vista e do Faxinal Preto, como também no perfil entre Rio do Sul e Serra Alta. Esta formação avança para o Estado do Paraná entre os rios Butiá e Três Barras e atinge o vale do Tibagí, passando por Teixeira Soares, Reserva e Monjolinhos, ao norte do salto Aparado. No Norte do Paraná, a jazida mais importante de carvão acha-se desenvolvida entre Caeté, Barra Bonita e Tomazina, onde o carvão atinge, às vezes, $50 \mathrm{~cm}$ de espessura.

\section{c) A formação post-glacial ou camadas Palermo $($ sinal $=C c)$}

Esta formação em nenhum dos seus horizontes sofreu as conseqüências da glaciação gonduânica, como aconteceu na formação Rio Bonito. É desprovida de carvão e constituída principalmente por folhelhos areno-argilosos, azul-acinzentados, 
cinzento-claros, pardacentos ou amarelados e por arenitos vermelho-amarelados até brancos, estratos que se alternam numa espessura de 50 a $90 \mathrm{~m}$. As camadas contêm, ao lado de impressões raras de plantas e insetos, especialmente pequenos lamelibrânquios, madeiras silicificadas, faixas e nódulos de sílex. As camadas Palermo ocorrem sempre como capa na zona de distribuição dos horizontes de carvão da formação Rio Bonito. Mackenzie Gordon Jr. reúne o antigo grupo Bonito, denominando-o formação Rio Bonito, e as camadas Palermo como grupo Guatá, divisão que nós aceitamos em nossos trabalhos sobre Lycopodiopsis derbyi (1947) e sobre os traços fundamentais da geologia do Paraná e Santa Catarina (1947). Baseados nas nossas recentes pesquisas das camadas glaciais e nas explanações de Mackenzie Gordon Jr. (1947) apresentamos a seguinte subdivisão da série Tubarão:

\author{
Série Tubarão \\ b) grupo Guatá \\ 2 - camadas Palermo \\ 1 - formação Rio Bonito (formação carbonífera) \\ a) grupo Itararé \\ 2 - formação Taió (fácies glacial-marinho) \\ 1 - formação Palmira (fácies continental-glacial)
}

\section{C.5 - O permiano ou a série Passa Dois $($ sinal $=$ Pmc $)$}

Os depósitos permianos representam, no Paraná e Santa Catarina, a mais potente seqüência de sedimentos que ocupa a maior área das regiões descritas. Nestas camadas verifica-se uma engranzagem complicada de fácies, ainda pouco estudada, de sedimentos neríticos, de lagunas litorâneas e de estuário. Antigamente, era anexada ao permiano também a seqüência total das camadas da série Tubarão, inclusive os sedimentos glaciais da lapa. Porém, apenas as camadas betuminosas com Mesosaurus do grupo Irati representam o primeiro horizonte seguramente permiano. Na seguinte tabela indicamos nossa nova classificação da série Passa Dois, não sendo possível publicar aqui mais detalhes de nossas respectivas pesquisas.

\begin{tabular}{|c|c|c|c|c|}
\hline \multicolumn{5}{|c|}{$\begin{array}{l}\text { capa: arenito Botucatu terrestre, em parte fácies fluvial Pirambóia } \\
\text { Discordância de erosão e transgressão (hiato) }\end{array}$} \\
\hline \multicolumn{5}{|c|}{$\begin{array}{l}\text { Série Passa Dois } \\
\end{array}$} \\
\hline \multirow{2}{*}{\multicolumn{2}{|c|}{ 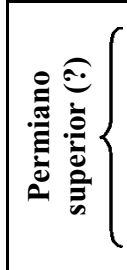 }} & \multirow{2}{*}{ 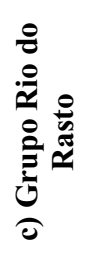 } & 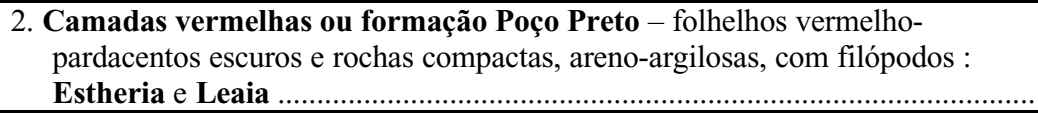 & ca. $15-65 \mathrm{~m}$ \\
\hline & & & $\begin{array}{l}\text { 1. Formação Esperança - folhelhos e siltitos de coloração alternante, violácea, } \\
\text { esverdeada, avermelhada, amarelada e azulada; camadas areno-argilosas, sem } \\
\text { carbonato de cálcio, ricas em elementos da flora de Glossopteris; ainda } \\
\text { lamelibrânquios (Palaconeilo, Terraia, etc.) e filópodos (Estheria, etc.) .......... }\end{array}$ & ca. $60-70 \mathrm{~m}$ \\
\hline \multirow{2}{*}{\multicolumn{2}{|c|}{ 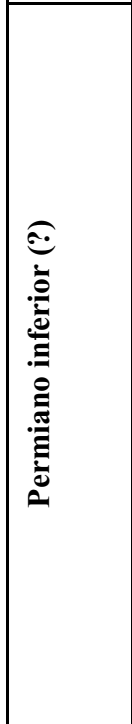 }} & \multirow[t]{2}{*}{ 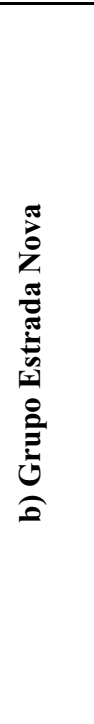 } & $\begin{array}{l}\text { 2. Camadas Terezina - Serrinha - folhelhos cinzentos, cinzento-esverdeados e } \\
\text { cinzento-violáceos, com bancos calcáreos claros e escuros, } \\
\text { predominantemente oolíticos, nódulos e arenitos calcáreos e faixas de sílex; } \\
\text { na parte superior camadas areno-argilosas de desagregação esferoidal; } \\
\text { folhelhos com concreções calcáreas ou folhelhos calcáreos (margas) com } \\
\text { lamelibrânquios, filópodos, impressões vegetais e madeiras silicificadas } \\
\text { (Lycopodiopsis derbyi, etc.) } \\
\text { B - Horizontes } 4 \text { e 5, zona com Solenomorpha similis, Terraia, Jacquesia, } \\
\text { Pinzonellopis, Pseudocorbula e Myoconcha } \\
\text { na parte inferior bancos calcáreos escuros, cinza-claros ou diferentemente } \\
\text { coloridos e lentes calcáreas ou estreitas faixas de sílex, facialmente } \\
\text { engranzadas com os folhelhos da formação Estrada Nova s. str., ou } \\
\text { camadas Serra Alta respectivamente } \\
\text { A - Horizontes } 1 \text { e 2, zona com Pinzonella, Terraia, Plesiocyprinella, } \\
\text { Pleurophorus e Ferrazia ................................................................... }\end{array}$ & $85 \mathrm{~m}$ \\
\hline & & & 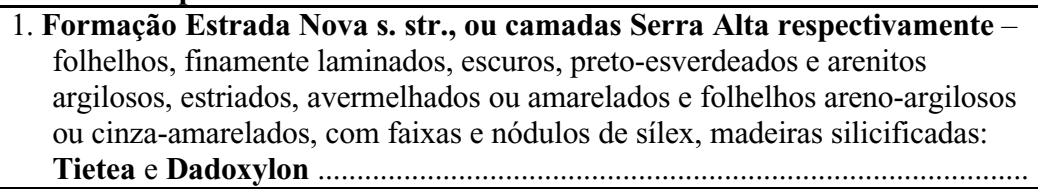 & ca. $95-145 \mathrm{~m}$ \\
\hline
\end{tabular}




\begin{tabular}{|c|c|c|c|}
\hline \multirow{3}{*}{ 离 } & \multirow{3}{*}{ 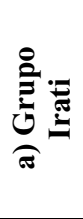 } & 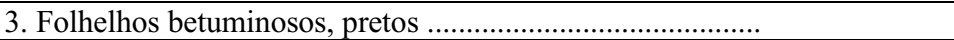 & ca. $2-10 \mathrm{~m}$ \\
\hline & & 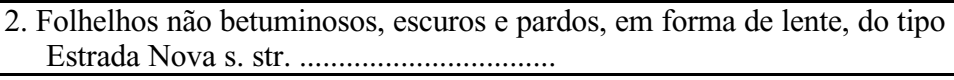 & $-10 \mathrm{~m}$ \\
\hline & & $\begin{array}{l}\text { 1. Xistos betuminosos, compactos pretos, decomposição em folhelhos, com } \\
\text { horizontes calcáreos: Mesosaurus e crustáceos }\end{array}$ & ca. $60-90 \mathrm{~m}$ \\
\hline & & 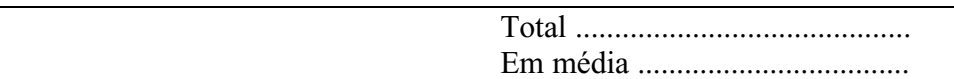 & $\begin{array}{l}\text { ca. } 297-475 \mathrm{~m} \\
\text { ca. } 386 \mathrm{~m}\end{array}$ \\
\hline \multicolumn{4}{|c|}{$\begin{array}{c}\text { Concordância (?) } \\
\text { lapa: Horizontes da série Tubarão - carbonífero superior }\end{array}$} \\
\hline
\end{tabular}

\section{1) O grupo Irati $($ sinal $=$ Pmc)}

O grupo Irati desenvolve-se com limite nítido em toda zona de distribuição das camadas gonduânicas, como horizonte-guia geral, com depósitos xistosos bem formados, betuminosos e pretos, desagregando-se em folhelhos finos e passando a cor por descoramento a branco ou azul-claro. Os xistos betuminosos freqüentemente incluem estratos e bancos de calcáreos claros. Às vezes, os calcáreos já jazem na base, como, por exemplo, a oeste de Imbituva, limitando o grupo Irati com a série Tubarão. As lentes calcáreas incluídas pelos xistos betuminosos podem atingir espessura de muitos metros, constituindo, então, um elemento morfológico particular na configuração da superfície do terreno. Na capa, desenvolvem-se, em concordância nítida, os folhelhos escuros da formação Estrada Nova s. str. diretamente sobre os xistos betuminosos pretos. Em certos lugares, principalmente no Paraná, na parte superior dos xistos betuminosos pretos, já são encontrados folhelhos escuros, não betuminosos, com 5 a $10 \mathrm{~m}$ de espessura, do tipo dos folhelhos Estrada Nova s. str. seguidos para cima, novamente, por folhelhos betuminosos, pretos ou marrom escuros, finamente laminados, com espessura de 2 a $10 \mathrm{~m}^{*}$. Apenas então aparecem, concordantemente, os folhetos da formação Estrada Nova s. str., ou das camadas Serra Alta respectivamente, que na zona de decomposição podem ser facilmente confundidos com os folhelhos intercalados, não betuminosos, do grupo Irati. A intercalação de lentes de folhelhos, não betuminosos, do tipo da formação Estrada Nova s. str. entre xistos betuminosos,

\footnotetext{
* Os xistos do grupo Irati incluem também extensas camadas de xistos pretos carbonosos e não betuminosos.
}

revela que as condições de sedimentação dos xistos escuros da formação Estrada Nova s. str. regionalmente já coexistiam com a deposição dos xistos betuminosos Irati. Assim originou-se uma engranzagem ou alternância rítmica do grupo Irati com os folhelhos do grupo Estrada Nova, como se pode observar entre as camadas glaciais do grupo Itararé e os horizontes de carvão do grupo Guatá ou também na capa entre as formações Estrada Nova s. str. e Terezina. Em virtude deste desenvolvimento singular das camadas Estrada Nova, saídas do grupo Irati, e em consideração da uniformidade de toda seqüência de sedimentos do grupo Estrada Nova, a idade permiana superior torna-se duvidosa. As recentes pesquisas revelam uma unidade geológica para a série Passa Dois, desde os xistos Irati até a capa da formação Terezina. Não correspondendo incondicionalmente o conteúdo fossilífero desta seqüência de sedimentos ao permiano superior e indicando, de outro lado, os fósseis vegetais antes uma associação florística do permiano inferior (Rotliegendes) do que permiano superior (Zechstein) consta em nossa nova tabela estratigráfica para as camadas médias e inferiores da série Passa Dois, engranzadas facialmente, com reserva, ainda permiano inferior.

Subdividimos o grupo Irati como segue:

3. folhelhos betuminosos, pretos;

2. folhelhos não betuminosos, escuros ou cinzentos;

1. xistos betuminosos, com lentes e estratos de calcáreos.

A possança dos xistos Irati é variável e revela $30 \mathrm{~m}$, $62 \mathrm{~m}, 70 \mathrm{~m}, 75 \mathrm{~m}, 90 \mathrm{~m}$ e, raramente, até $100 \mathrm{~m}$ de espessura. $\mathrm{O}$ fóssil característico dos xistos betuminosos pretos é um réptil de 40 a $60 \mathrm{~cm}$ de comprimento, descrito por Mac Gregor como Mesosaurus brasiliensis (WHITE, 1908). Nos calcáreos do grupo Irati encontra-se um réptil semelhante, descrito por Cope, em 1885, como 
Stereosternum tumidum. F. V. Huene é de opinião de que ambas as formas de répteis são idênticas ao Mesosaurus tenuidens Gervais (1867). Além dos répteis dos xistos Irati dos Estados de Santa Catarina e São Paulo, Karl Beurlen e J. M. Clarke descreveram as seguintes formas de uma fauna de crustáceos:

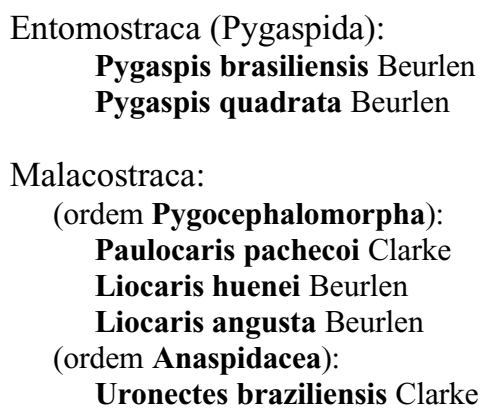

Os xistos Irati ocorrem em toda extensão da frente da Serra Geral em Santa Catarina, estendendo-se Paraná a dentro por Três Barras São Mateus - Irati. Observam-se os afloramentos dos xistos betuminosos, passando por Bitumirim (ex-Bom Jardim) - Ortigueira (ex-Queimadas) até o rio Tibagí, onde cruzam o vale deste rio no arroio Barra Grande. Seguem para leste, através dos rios Lageado Liso, Laranjinhas e das Cinzas, mergulhando, finalmente, sob camadas tectoras mais recentes.

\section{2) O grupo Estrada Nova (sinal =Pmc)}

As camadas do grupo Estrada Nova, quanto ao limite superior, entre o permiano e o triássico superior, representam uma formação, no sistema gonduânico, tão problemática e discutida como as do grupo Rio do Rasto que seguem para cima. Segundo a primeira classificação estratigráfica do sistema Santa Catarina, por WHITE (1908), o grupo Estrada Nova terminava com um banco calcáreo de $3 \mathrm{~m}$ de espessura, o calcáreo de Rocinha, também denominado grupo Rocinha (fig. 96). Em pesquisas posteriores verificou-se que o banco calcáreo de Rocinha não representa uma capa uniforme, ocorrendo apenas lentes e horizontes calcáreos, engranzados irregularmente com os folhelhos da formação Estrada Nova s. str. Os horizontes calcáreos sob forma de chapas, lentes e bancos, mais ou menos espessos, distribuem-se sobre uma seqüência de camadas de 50 a $60 \mathrm{~m}$, sendo intercalados, freqüentemente, por xistos duros, cinza- esverdeados, finamente listrados, com ripple-marks ou também folhelhos moles (fig. 97 a 100). Em vastas extensões podem faltar os calcáreos compactos, sendo substituídos por folhelhos calcáreos com nódulos calcáreos ou por arenitos calcáreos (fig. 100). Entre os bancos calcáreos, dois horizontes são particularmente ricos em lamelibrânquios silicificados. A classificação desta malacofauna por COWPER REED (1928), como pertencente ao triássico superior, levou ao desmembramento dos horizontes calcáreos da série Passa Dois e conseqüente inclusão na "série Rio do Rasto", como grupo Terezina, apesar da engranzagem facial com folhelhos escuros da formação Estrada Nova s. str. e sem considerar o fato de que HOLDHAUS (1919) havia descrito anteriormente dos horizontes superiores exclusivamente formas permo-carboníferas dos lamelibrânquios, tais como: Solenomorpha altíssima, $S$. similis, S. intermédia e S. deflexa, Sanguinolites sp. e $S$. elongata, como também o novo gênero Plesiocyprinella. A exatidão das determinações de fósseis por HOLDHAUS foi posta em dúvida. Das espécies de Solenomorpha, descritas por HOLDHAUS, COWPER REED (1929) colocou duas no gênero Cuspidaria, que ocorre desde o triássico, denominando-se Cuspidaria similis (Holdh.) e Cuspidaria ? deflexa (Holdh.). Além disto, F. R. Cowper Reed determinou uma espécie de Solenomorpha como Myophoria (Heminajas) ? intermedia (Holdh.). Baseado nos seus estudos dos lamelibrânquios do Uruguai, Leslie R. Cox (1934) criou posteriormente o gênero Terraia altissima (Holdhaus) e também a forma Isocyprina reducta, descrita por F. R. Cowper Reed.

Dos horizontes calcáreos que jazem 17,60 m abaixo do banco fossilífero de Holdhaus, no perfil das camadas Terezina, e de um horizonte de folhelhos esverdeados, situado $1,60 \mathrm{~m}$ acima deste banco, COWPER (1928) descreveu de Malet, Rio Claro e Água Quente formas de lamelibrânquios somente do triássico superior, das quais atribuiu posição chave aos Myophoriopis e Pachycardia relativamente ao caráter triássico superior da malacofauna. Posteriormente, Josué Camargo Mendes, estudando material fossilífero melhor conservado, revelou, em 1944, 1945 e 1946, que os moluscos em questão não pertencem aos gêneros Myophoriopis e Pachycardia, criando dois novos gêneros, Jacquesia e Pinzonellopis (MENDES, 1945, A; 1944, C e 1945, C). Assim desaparece o argumento mais importante em favor da idade triássica superior da fauna malacológica das camadas Terezina. 
Deve-se aduzir ainda que madeiras silicificadas e impressões vegetais não foram encontradas apenas nos horizontes dos lamelibrânquios, mas também, superiormente, em folhelhos calcáreos e em camadas areno-argilosas. Os estudos destes vegetais fósseis, por Zeiller (HOLDHAUS, 1919), revelaram apenas uma composição florística de elementos da flora paleozóica. Este fato, aliás, foi confirmado por achados posteriores, pois nos mais diversos horizontes das camadas Terezina foram verificados elementos particularmente característicos da flora paleozóica, como especialmente, Lepidodendron e Lycopodiopsis derbyi, e fora destes Glossopteris angustifolia Brongn., Gl. browniana Brongn., Phylloteca, Pecopteris sp., Sigillaria muralis, Taeniopteris, Tietea, etc. Destes elementos, Glossopteris angustifolia e Gl. Browniana são encontrados na totalidade das camadas gonduâncias, enquanto que Lepidodendron e Lycopodiopsis acompanham o desenvolvimento das camadas gonduânicas apenas do carbonífero até o permiano. Trata-se de elementos típicos da flora gonduânica mais antiga que, como Sphenophyllum, desaparecem definitivamente com o término do permiano. Pecopteris e Taeniopteris, porém, são típicos para o permiano inferior, aparecendo Taeniopteris também nas camadas Beaufort inferiores da África do Sul. Mesmo a ocorrência eventual de Cladophlebis sp. entre os elementos florísticos das camadas Terezina não pode ser tida como prova para a idade triássica destas camadas. A associação deste vegetal com uma flora carbonífero-permiana típica indica antes uma idade paleozóico-permiana do que uma mesozóico-triássica, correspondendo à uma flora que caracteriza as camadas Beaufort da África do Sul, no limite entre o permiano e triássico. O caráter paleozóico dos elementos florísticos está de pleno acordo com as determinações faunísticas de $\mathrm{K}$. Holdhaus e com as recentes pesquisas de Josué Camargo Mendes (fig. 16). Finalmente, é de particular importância o fato de que a fauna de crustáceos de Valões e Poço Preto, os filópodos Estheria e Leaia, descritos como permo-carboníferos por F. R. Cowper Reed, não ocorrem em camadas Estrada Nova s. str. típicas, mas sim nos horizontes vermelhos do grupo Rio do Rasto, denominados por nós formação Poço Preto. Estes filópodos, porém, surgem já nos horizontes de lamelibrânquios das camadas Terezina, sendo encontrados novamente até poucos metros abaixo da base do arenito Botucatu. Todos estes argumentos depõem, de modo claro e convincente, em favor da idade paleozóica da seqüência total de camadas, desde os xistos Irati até a base do arenito Botucatu. Este resultado ainda é acentuado pela seqüência concordante de camadas, na qual não se pode observar alguma discordância importante e nem um hiato. A sucessão imediata do triássico superior ao permiano superior exige logicamente um hiato. Porém, o hiato entre permiano e triássico verifica-se apenas na discordância de erosão entre as camadas vermelhas Rio do Rasto e a base do arenito Botucatu (fig. 10). Por este motivo e considerando também a engranzagem facial com a formação Estrada Nova s. str., anexamos as camadas Terezina novamente à série Passa Dois do permiano, subdividindo a seqüência das camadas do grupo Estrada Nova em:

1. Formação Estrada Nova s. str., ou camadas Serra Alta respectivamente

2. Camada Terezina - Serrinha

\section{a) A formação Estrada Nova s. str. ou camadas Serra Alta respectivamente}

Esta formação é constituída por uma alternância de folhelhos finos, preto-esverdeados, com pequenas lentes calcáreas, por xistos listrados, cinzentoesverdeados e por arenitos argilosos, vermelhoamarelados. Como mencionamos acima, os folhelhos escuros, ou preto-esverdeados, acham-se desenvolvidos já na capa do grupo Irati, entre xistos betuminosos. A espessura total da formação Estrada Nova s. str. varia entre 90 e 145 m. A seqüência destas camadas, particularmente na capa, é caracterizada por faixas estreitas ou nódulos grossos de sílex. Pequenas lentes calcáreas observam-se especialmente no perfil Imbituva - Prudentópolis no Estado do Paraná. As camadas são ricas em madeiras silicificadas, levadas pela água aos depósitos de estuários ou neríticos. Entre as numerosas espécies de madeiras, foram determinadas até agora: Dadoxylon nummularium, Sigillaria muralis, Tietea singularis e Tietea $s p$.

\section{b) As camadas Terezina - Serrinha}

As camadas Terezina - Serrinha representam uma seqüência de bancos calcáreos na capa da formação Estrada Nova s. str., sem discordância ou hiato verificável. Uma limitação nítida das camadas Terezina com a formação Estrada Nova s. str. não se pode observar, em vista da engranzagem facial. Em 
várias regiões de Santa Catarina, os folhelhos preto-esverdeados típicos das camadas Estrada Nova s. str. foram encontrados ainda sobre horizontes calcáreos de Terezina, por exemplo, no km 46 a oeste de Serra Alta. Entre os bancos calcáreos ocorrem xistos duros, cinzentoesverdeados ou de cor variegada, com ripplemarks, e, na capa, arenitos calcáreos e folhelhos calcáreos claros, cinzento-azulados, cinzentovioláceos ou cinzento-esverdeados com nódulos calcáreos (fig. 100). Particularmente típicas são as camadas areno-argilosas, de desagregação esferoidal, notavelmente desenvolvidas nos lugares onde faltam os bancos calcáreos duros, por exemplo, no morro do Panelão, em Santa Catarina, ou no perfil a oeste de Prudentópolis, no Paraná (fig. 101). A seqüência total das camadas revela notável riqueza em lamelibrânquios e fósseis vegetais conduzidos pela água aos sedimentos marinhos. Os calcáreos oolíticos predominantes, com seus bancos fossilíferos são de origem marinha. Semelhantemente à formação Estrada Nova $s$. str., uma parte das camadas sofreu uma silicificação posterior, explicada por Viktor Leinz pelas extensas intrusões e efusões posttriássicas de rochas eruptivas básicas. Os bancos calcáreos são membros incontínuos na seqüência. Enquanto que em alguns lugares, bancos isolados se repetem numa seqüência de camadas de 30 a $50 \mathrm{~m}$ de espessura, em outros são representados apenas por lentes ou chapas calcáreas de 0,5 a $1 \mathrm{~m}$ de espessura ou faltam, sendo substituídos por arenitos calcáreos.

Os horizontes fossilíferos das camadas Terezina foram divididos por F. L. Moraes Rego nos grupos Terezina e Serrinha. De outro lado, OPPENHEIM (1934) indicou as seguintes três formações:

\section{Camada Rocinha \\ Camada Terezina \\ Camada Serrinha}

Avelino Ignácio de Oliveira e Othon Henry Leonardos apenas mencionam as formações Terezina e Serrinha, fundamentando-as por uma fauna característica (OLIVEIRA e LEONARDOS, 1943). Consta como fóssil-guia da formação Terezina Pachycardia (Pinzonellopis segundo Mendes) e, como tipos característicos da formação Serrinha Isocyprina, Terraia altissima Holdhaus e Myophoria
(Jacquesia segundo Mendes). Mas, estes dois horizontes fossilíferos típicos estão situados, com muitos outros, em tão pequena distância vertical numa seqüência de camadas concordante e litologicamente igual, de modo que a separação em dois grupos ou formações distintas não parece conveniente. As formações Terezina e Serrinha são idênticas.

A espessura das camadas calcáreas e dos sedimentos areno-argilosos de desagregação esferoidal da formação Terezina varia, em conseqüência da engranzagem facial com a formação Estrada Nova s. str., entre 60 e $85 \mathrm{~m}$. Pode, entretanto, diminuir a espessura até $48 \mathrm{~m}$, ocupando, então, os bancos calcáreos um espaço muito reduzido. O seguinte gráfico elucida a disposição das camadas Terezina Serrinha (fig. 9).

\section{3) O grupo Rio do Rasto $($ sinal $=P u)$}

WHITE (1908) identificou primeiramente as camadas vermelhas Rio do Rasto com as camadas Santa Maria, com os Rhynchosaurus, do Rio Grande do Sul, sem basear-se em levantamentos de perfis ou pesquisas petrográficas. Desde então, também as camadas vermelhas na capa da série Rio do Rasto, no Paraná e Santa Catarina, foram denominadas Grupo Santa Maria. Porém, no perfil Rio Pardo Santa Cruz e São Sepé - Santa Maria, pode ser verificado que as camadas da formação Santa Maria com os sáurios encontram-se mais para cima, sendo separadas inferiormente das camadas Rio do Rasto e superiormente do arenito Botucatu por discordâncias de erosão. Os mesmos folhelhos argilosos, vermelhos, das camadas Rio do Rasto com bancos de arenito vermelho na capa, como se observam em Porto União e na Serra da Bocaina em Santa Catarina, afloram também à margem do rio Pardo, sob a formação Santa Maria. De especial importância é o fato de encontrarmos, em nossas últimas pesquisas, nos horizontes vermelhos do grupo Rio do Rasto, os filópodos fósseis de Valões e Poço Preto, descritos por COWPER REED (1929; 1930).

Entre as camadas calcáreas da formação Terezina e as camadas vermelhas do grupo Rio do Rasto desenvolve-se uma seqüência de horizontes sem carbonato de cálcio, areno-argilosos, de coloração variegada - avermelhados, esverdeados, violáceos e amarelados -, cuja espessura varia entre 60 e $70 \mathrm{~m}$. Particularmente, os horizontes inferiores destes depósitos são ricos em impressões vegetais transportados pela água, pertencentes à flora de 
Glossopteris (Glossopteris indica, $G$. browniana, Pecopteris sp., Calamites, Phylloteca, etc.), revelando igualmente numerosos bancos fossilíferos com lamelibrânquios (Palaeoneilo) e os filópodos Estheria e Leaia. Separamos estas camadas, isentas de calcáreos, de coloração variegada, dos horizontes calcáreos de Terezina - Serrinha, denominando-as, como anteriormente, formação Esperança (MAACK, 1937). Distinguimos, portanto, no grupo Rio do Rasto as seguintes formações:

1. Uma formação de camadas areno-argilosas, de coloração variegada que, em contraste com os horizontes calcáreos e com os bancos de desagregação esferoidal de Terezina - Serrinha, são isentas de calcáreos, desagregando-se em palhetas finas como folhelhos; em nossa nova tabela estratigráfica aparecem como formação Esperança. Os diversos horizontes, de cores alternantes, são nitidamente limitadas entre si (fig. 102 e 103). Como limite inferior observa-se um horizonte argilo-arenoso, avermelhado, ou vermelho-violáceo, revelando evidentemente uma mudança das condições de sedimentação em comparação com as camadas Terezina. Na base deste horizonte avermelhado encontra-se uma leve discordância, limitada regionalmente, sob forma de uma linha ondulada, observável, por exemplo, a oeste de Serra Alta. O limite com as camadas Terezina freqüentemente é formado por um arenito calcáreo cinzento, sendo em alguns pontos de difícil verificação na zona de decomposição, em virtude da coloração semelhante aos folhelhos inferiores. As camadas da formação Esperança podem ser separadas facilmente dos folhelhos calcáreos por simples teste químico.

2. Uma seqüência de estratos limo-argilosos, notavelmente vermelho-castanhos ou intensamente vermelhos, freqüentemente formando bancos compactos, desagregando-se sempre em fragmentos mais grosseiros do que os folhelhos, finamente laminados, das camadas Estrada Nova até a formação Esperança. Destes horizontes vermelhos procedem os filópodos, examinados por F. R. Cowper Reed, Estheria regularis, E. neotropica, E. subalata, como Leaia pruvosti, L. curta e L. unicosta, fauna que Cowper Reed designou como permocarbonífera. Encontramos Estheria ainda nas camadas vermelhas Rio do Rasto, 19 m abaixo da base do arenito eólico Botucatu e $1 \mathrm{~m}$ abaixo da base de um arenito fluvial, argiloso e vermelho, no pedestal da serra Esperança, no Paraná, e na Serra da Bocaina, em Santa Catarina (fig. 104). Denominamos estas camadas vermelhas do grupo Rio do Rasto formação Poço Preto, em vista de que naquele lugar foram achados, pela primeira vez, os filópodos.

Considerando-se a idade geológica da fauna dos crustáceos, determinados por F. R. Cowper Reed, e o fato do desenvolvimento concordante das camadas da série Passa Dois até estes horizontes vermelhos, sem indícios de uma discordância de erosão ou de um hiato, que documentaria o limite entre o permiano superior e o triássico superior, colocamos as camadas Rio do Rasto no permiano superior, anexando-as à série Passa Dois. Apenas acima dos horizontes vermelhos do grupo Rio do Rasto e abaixo do arenito Botucatu pode ser observada a grande discordância de erosão com o hiato entre $\mathrm{o}$ permiano e o triássico, faltando, tanto no Paraná como em Santa Catarina, a formação Santa Maria com os sáurios (fig. 10 e 16).

\section{D - ERA MESOZÓICA}

Dentro dos depósitos mesozóicos do Brasil Meridional, apenas uma única formação, pelo seu conteúdo fossilífero, teve a sua idade geológica paleontologicamente determinada. Trata-se das camadas vermelhas Santa Maria, no Rio Grande do Sul com os Anomodontia, Cynodontia, Rhynchosauridae, Pseudosuchia e Saurischia do triássico superior. Entretanto, a idade do arenito terrestre Botucatu, que segue superiormente, ainda é incerta, em virtude da falta de fósseis. De modo geral, considera-se para este arenito, como idade mais provável, o rético, isto é, o triássico superior. Admite-se, geralmente, também ainda o rético para o derrame superior de eruptivas básicas e os diques, sills e stocks de diabásio, entremeados no sistema gonduânico. É bem possível, contudo, que, tanto o arenito Botucatu como o lençol eruptivo, pertençam ao jurássico inferior, ou ao andar liássico respectivamente. Isto é muito provável, pelo menos, para o lençol eruptivo, de modo que o triássico é representado, no Paraná e Santa Catarina, apenas pelo arenito terrestre Botucatu. Portanto, o período triássico no Brasil Meridional, desde o triássico inferior até o médio, revela uma época de intensa erosão e denudação, da qual resultou, de um lado, a discordância e o hiato entre as camadas Rio do Rasto e Santa Maria e, por outro, entre o arenito Botucatu e as camadas rio do Rasto. $\mathrm{Na}$ base do arenito eólico Botucatu, freqüentemente pode ser observado um fácies fluvial, com arenitos argilosos, vermelhos, de estratificação cruzada rasa e com estratos de 
\{

pedregulho. A discordância entre o paleozóico e o mesozóico, então, é encontrada abaixo deste fácies fluvial. Comparamos este fácies fluvial, argiloso, vermథlho, corn o arenito Pirambóia do Estado de \$ão Pałlo, denominando esta formação no Raraná o Santa Catarina, por este motivo, fácies Pirambóia do grupo Botucatu. Arenitos também ocorrem ainda entre os diversos lençóis de rochas eruptivas básicas. Areias posteriormente silicificadas preenchem fendas da capa eruptiva, de modo que dentro deste derrame eruptizo aparecem arenitos em forma de diques. Também acima das rochas eruptivas básicas, a sedimentação de arenitos eólicos mesozóicos continuou como indício de uma paisagem desértica mesozóica. Estes arenitos da capa, cuja idade mais provável é o liássico, foram por nós denominados de arenito de São Bento superior ou Caiuá (MAACK, 1941).
Entre o arenito Caiuá e o lençol de trapp, assim como na capa, não podem ser observadas as camadas lacustres e calcáreas Bauru do período cretáceo. O arenito Caiuá desenvolve-se, no Paraná, imediatamente sobre o lençol eruptivo, por assim dizer, partindo diretamente da última fase do derrame. Estas verificações são importantes, quanto à posição estratigráfica do arenito Caiuá, o qual pretende-se, recentemente, anexar de novo às camadas Bauru, ou ao cretáceo respectivamente (OLIVEIRA e LEONARDOS, 1943, p. 418). Segundo nossas pesquisas, a sedimentação terrestreeólica predomina desde o arenito São Bento inferior ou Botucatu, durante todo o período vulcânico, até o arenito São Bento superior ou Caiuá. As camadas Bauru, pelo contrário, representam, em sua maior parte, depósitos lacustres com calcáreos. Baseados nestas verificações, chegamos à seguinte subdivisão do mesozóico, no Paraná e Santa Catarina:

\begin{tabular}{|c|c|c|c|c|}
\hline \multirow{4}{*}{ 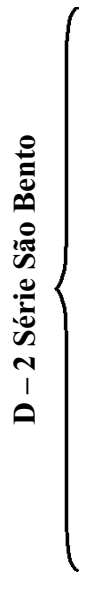 } & \multirow{2}{*}{ 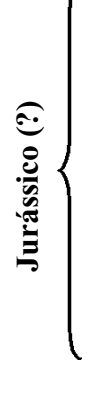 } & 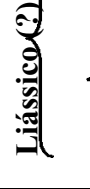 & 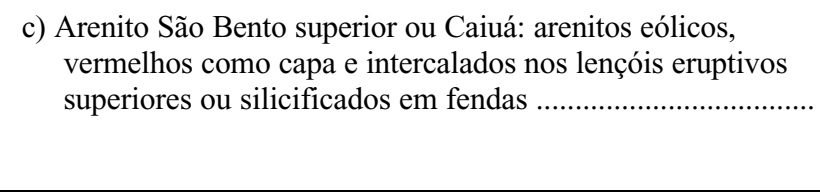 & ca. $20-270 \mathrm{~m}$ \\
\hline & & 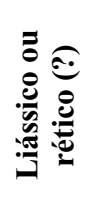 & 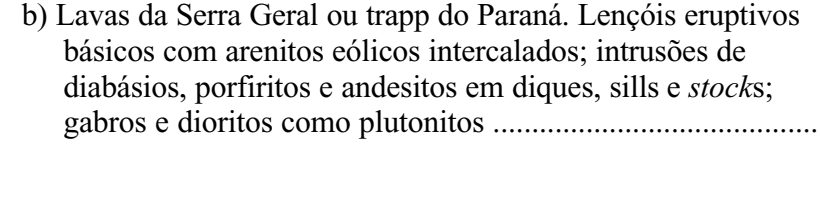 & ca. $50-800 \mathrm{~m}$ \\
\hline & \multirow{2}{*}{ 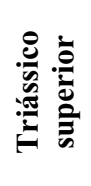 } & \multirow{2}{*}{ 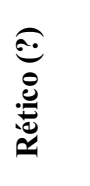 } & $\begin{array}{l}\text { a) 2. Arenito São Bento inferior ou Botucatu, arenitos eólicos, } \\
\text { avermelhados, amarelados ou brancos e depósitos em bacias } \\
\text { sem escoamento de uma paisagem desértica ........ }\end{array}$ & ca. $50-260 \mathrm{~m}$ \\
\hline & & & $\begin{array}{l}\text { 1. Arenitos fluviais, argilosos, vermelhos, com estratos de } \\
\text { pedregulho; fácies Pirambóia (?) }\end{array}$ & ca. $5-10 \mathrm{~m}$ \\
\hline \multicolumn{5}{|c|}{ discordância de erosão e transgressão } \\
\hline 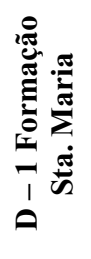 & 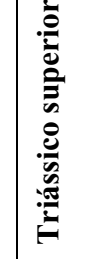 & 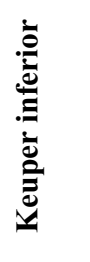 & $\begin{array}{l}\text { Argilas vermelhas; arenitos vemelhos com estratificação } \\
\text { esntrecruzada; com Rhynchosaurus e Cynodontia, etc.; } \\
\text { madeiras fósseis; observados apenas no Rio Grande do Sul ... }\end{array}$ & ca. $70-85 \mathrm{~m}$ \\
\hline \multicolumn{4}{|r|}{ Total …......................................... } & ca. $195-1425 \mathrm{~m}$ \\
\hline
\end{tabular}




\section{D.1 - Período triássico : Andar Keuper inferior ou formação Santa Maria}

As camadas com répteis até agora não foram verificadas nem no Paraná, nem em Santa Catarina, por cujo motivo prescindimos aqui de pormenores. A formação Santa Maria, no Estado do Rio Grande do Sul, é constituída por arenitos vermelhos, com estratificação entrecruzada rasa (fig. 105), por camadas de folhelhos, vivamente vermelhos, e por argilas maciças, da mesma cor. Horizontes com madeiras fósseis jazem 33 a $36 \mathrm{~m}$ sob a base do arenito Botucatu, ocorrendo $17 \mathrm{~m}$ abaixo destes (50 a $53 \mathrm{~m}$ abaixo do Botucatu) as argilas vermelhas, lavadas e erodidas em voçorocas, com grande quantidade de restos ósseos de uma fauna de répteis do tipo Keuper. Em Santa Maria da Boca do Monte foram encontrados, entre Rhynchosauridae, o conhecido Scaphonix fischeri Woodward e Cephalonia lotziana v. Huene; além destes ocorrem Cynodontia e Pseudosuchia. Em Chiniqua - São Pedro até agora foram verificados 4 Cynodontia, 6 Pseudosuchia e 1 Saurischia, como também 3 Anomodontia, entre os quais foi determinado o Stahleckeria potens v. Huene. Também de Santa Cruz (Candelária), no Rio Grande do Sul, Romer e Price descreveram uma fauna semelhante com um gigantesco Dicynodontia, o Stahleckeria lenzii Romer \& Price.

\section{D.2 - A Série São Bento}

\section{1) O andar rético do triássico (liássico?), ou arenito São Bento inferior ou Botucatu $\quad($ sinal $=$ Trc $)$}

$\mathrm{O}$ arenito Botucatu transgride muito além da base das outras camadas gonduânicas, jazendo, muitas vezes, imediatamente sobre rochas cristalinas do peneplano pre-gonduânico. Em vista do arredondamento e polimento dos grãos de quartzo, a limitação inferior do arenito Botucatu eólico, em casos duvidosos, pode ser verificada já por uma simples lupa. Maiores dificuldades existem quando na base jaz o fácies fluvial Pirambóia com arenitos argilosos, vermelhos, constituídos por material de desagregação das camadas vermelhas Rio do Rasto, contendo, então, o mesmo material sedimentar fino e vermelho-escuro. Nestes casos, a discordância de erosão entre o permiano e o triássico e, por vezes, estratos de pedregulho, ou camadas com estratificação entrecruzada rasa, evidenciam claramente o limite inferior do triássico no Paraná e Santa Catarina (fig. 10 a-c, 11 a, 103, 104 e 106).

A cor do arenito eólico Botucatu com sua estrutura típica das areias movediças (fig. 106) é predominantemente vermelho-clara, e, às vezes, amarela e branca. Nos bancos de arenitos, os dreikanters não são raros. Pela lavagem da superfície (Flächenspülung), os depósitos fluviais revelam engranzagem com o fácies eólico. $\mathrm{O}$ arenito Botucatu, em seu desenvolvimento integral, é caracterizado pelos depósitos desérticos em forma de dunas, escudos arenosos e sedimentos fluviais de depressões sem escoamento. A limitação com as rochas de trapp mostra um plano erodido, mas a sedimentação eólica se prolongou também durante a época vulcânica.

O fácies fluvial Pirambóia do arenito Botucatu mede, em média, 5 a $10 \mathrm{~m}$ de espessura, podendo atingir até $20 \mathrm{~m}$. O fácies eólico do arenito Botucatu revela espessura variável, oscilando entre 50 e $260 \mathrm{~m}$. Na extensão total da Serra Geral, da Serra do Espigão e da Serra da Boa Esperança, o arenito Botucatu forma degraus e paredões (fig. 38 a 40 e 107).

\section{2) O lençol eruptivo básico do andar rético (?) ou liássico (?) (sinal = Tr)}

As rochas eruptivas básicas escuras que romperam em fendas a seqüência total das camadas gonduânicas, cobrindo-as com lençóis, são denominadas lavas da Serra Geral ou trapp do Paraná. O derrame eruptivo freqüentemente inclui ainda grandes chapas ou bancos de arenitos vermelhos, ou lençóis singulares de trapp alternam com bancos de arenito. Tais arenitos incluídos no lençol de trapp são, na capa, fortemente cozidos e contêm bombas vulcânicas. Da maneira da disposição dos arenitos e das lavas derramadas sobre eles ressalta claramente que a sedimentação do arenito Botucatu eólico, nas suas partes superiores, coincide com a formação dos lençóis eruptivos. A figura 11 representa as relações de jazimento entre o arenito Botucatu e a capa de rochas eruptivas. 
As lavas ascenderam por fendas de tração que, tanto no litoral como no planalto do interior, cortam, em paralelismo notável, rochas cristalinas e camadas gonduânicas, na direção $\mathrm{N} 40-45^{\circ} \mathrm{W}$. Os diques são predominantemente verticais. Raramente ocorrem diques com inclinação oblíqua ou em ziguezague irregular, como geralmente são representados nos perfis esquemáticos (fig. 68). Os plutonitos correspondentes, dos diques e dos lençóis de lava básicos, afloram apenas em casos especiais, como, por exemplo, gabro nos cortes profundos dos vales que levam ao rio Ribeira, entre os $\mathrm{km} 12$ e 14,8, ao longo e ao lado da estrada Paraná - Curitiba (fig. 7a) e no ribeirão Laranjal no município de Imbuial (Bocaiúva do Sul), como dioritos no litoral e no primeiro planalto do Paraná. Uma rocha gabróide observa-se no pedestal do morro do Jahn, a oeste de Joinville.

Entre as rochas eruptivas básicas do grande derrame de trapp do Paraná distinguimos dois tipos principais de rochas, aos quais juntam-se algumas variações, caracterizadas somente pela textura. São eles:

1. Meláfiros

variações: a) meláfiros com drusas grossas e preenchimentos silicosos, como ágata, ametista e cristal de rocha b) meláfiros com drusas finas de calcita e heulandita

c) espilitos

2. Diabásios variações:
a) diabásios intersticiais
b) diabásios-porfiritos (basaltitos ou augita-porfiritos)
c) toleitos

Nos preenchimentos de fendas, isto é, das rochas de diques e sills, predominam diabásios de granulação fina até grosseira; entretanto, também diabásio-porfiritos e andesitos ocorrem freqüentemente em diques. Uma diferenciação ácida, com quartzo-(dacito-) porfirito, de granulação grossa, numa extensa dilatação de um dique de andesito, em Fortaleza no município de Tibagí, foi introduzida por Viktor Oppenheim, na literatura geológica como sienito-pórfiro de Tibagí (MAACK, 1946b). Estes sienito-pórfiros porém, não verificamos na zona mencionada por Oppenheim; procuramos o lugar segundo o mapa de Oppenheim, encontrando lá apenas andesitos e quartzo- (dacito-) porfiritos. Nas rochas dos diques neoaté post-triássicos, do litoral até os planaltos do Paraná e Santa Catarina, distinguimos também apenas dois tipos principais de rochas básicas, a saber:

1. Diabásios de granulação fina até grosseira, de textura ofítica ou intersticial variações: diabásio-porfirítico

2. Andesitos de textura porfirítica variações: quartzo-(dacito-) porfirito

Como rochas plutônicas juntamos:

1. Gabro de granulação média e gabroporfiritos

2. Dioritos e quartzo-dioritos

Levantando-se um perfil dos diversos lençóis de lavas da bacia do Paraná, verificam-se, numa alternância determinada, lavas em blocos grosseiros, isto é, meláfiros com drusas grandes, camadas laminadas de diabásios intersticiais (fig. 108), meláfiros com drusas finas de calcita e heulandita, diabásios de desagregação esferoidal (fig. 111) e Fladenlava (lava cordada, fig. 110). Ao longo da Serra da Boa Esperança, os diabásio-porfiritos formam os derrames superiores, particularmente na Serra Bufadeira, Serra dos Agudos (fig. 41), Serra da Pitanga e, no planalto, nas vizinhanças de Guarapuava. Alguns perfis através dos lençóis de eruptivas básicas elucidam o ritmo do derrame (fig. 12).

Os diques de diabásio ocasionam os números rápidos e saltos nos rios dos planaltos do Paraná e Santa Catarina, formando-se, muitas vezes, pela força de erosão das águas, profundos entalhes ao longo das linhas de estrutura ou diáclases (fig. 112). Também pelas bordas escalonadas das chapas estruturais dos lençóis eruptivos são originados rápidos e saltos no terceiro planalto (fig. 42, 46, 47 e 113).

\section{3) O arenito São Bento superior ou Caiuá do jurássico inferior, ou do andar liássico respectivamente $($ sinal $=J)$}

As condições de sedimentação, predominantes durante a deposição do arenito São Bento inferior, ou Botucatu respectivamente, amontoados arenosos eólicos numa paisagem desértica mesozóica, continuaram também na última fase dos derrames vulcânicos e na época 
post-vulcânica. Entre os lençóis eruptivos superiores acham-se bancos arenosos cozidos, sendo preenchidas muitas fendas da superfície escabrosa do último lençol de lava com areias eólicas, as quais, pela silicificação posterior, formam, de certo modo, diques de arenito na capa eruptiva. Diretamente sobre o lençol de trapp ainda foi depositada areia movediça sob forma de escudos arenosos e campos de dunas. Esta areia desértica constitui agora o arenito supratrapp vermelho-escuro e fortemente ferroso em sua base, pela influência do derrame de lava, arenito que denominamos São Bento superior, ou Caiuá respectivamente (MAACK, 1941). Portanto, no Paraná, este arenito desenvolve-se imediatamente da capa eruptiva, ainda em conexão com a última fase de derrame das lavas. $\mathrm{O}$ arenito Caiuá foi separado, como membro da base, das camadas Bauru por G. Florence, J. Pacheco e Chester W. Washurne (1930), e tratado como formação independente que se desenvolve diretamente sobre as rochas eruptivas básicas. Arenitos vermelhos, observados supostamente entre as camadas calcáreas e lacustres Bauru, não podem corresponder ao arenito Caiuá.

Apesar de termos referido já nos anos de 1936, 1937, 1940 e 1941 (MAACK, 1937 e 1941), pela primeira vez, à existência do arenito Caiuá com representação cartográfica quanto à sua distribuição, o mesmo não é mencionado, para o Paraná, nem na "Geologia do Brasil" (OLIVEIRA e LEONARDOS, 1943), nem por PAES LEME (1943). No mapa geológico do Brasil de 1943 não é reproduzido de acordo com nossas indicações cartográficas de 1940 e 1941. Neste mapa que acompanha também a "Geologia do Brasil", o limite sul do arenito Caiuá aparece ainda muito além do rio Piquirí, o que não corresponde à realidade (ver mapa em MAACK, 1941).

No Paraná, o arenito Caiuá abrange uma área de aproximadamente $14.000 \mathrm{~km}^{2}$, ultrapassando muito a zona de distribuição do devoniano. A espessura da chapa de arenito, nas mesetas da zona limítrofe leste, perto de Sabaudia e a sudeste de Campo Mourão, é de 20 a $60 \mathrm{~m}$, crescendo para oeste até $270 \mathrm{~m}$. Mergulha numa inclinação de $0,89 \mathrm{~m}$ por quilometro para norte, em direção ao rio Paranapanema, e 2,63 m por quilometro para oeste, rumo rio Paraná. O arenito castanho-avermelhado exibe estrutura eólica bem típica que, atualmente, pela lavagem das linhas de estrutura, pode simular um mergulho forte em vista da inclinação de $30^{\circ} \mathrm{da}$ estratificação entrecruzada, de modo que sempre as linhas inclinadas tocam linhas horizontais (fig. 114). Na zona de decomposição, o arenito Caiuá transforma-se em areia avermelhada, fofa e profunda. Em conseqüência do grande teor em ferro, freqüentemente formam-se, pela desagregação, grandes blocos de canga que ocorrem mormente sobre as chapas de arenitos nos vales dos rios (fig. 115).

Em Santa Catarina, o arenito Caiuá até agora não foi verificado. Glycon de Paiva menciona, porém, de uma perfuração em Lajes, sedimentos vermelhos, supratrapp de $50 \mathrm{~m}$ de espessura, sendo ainda incerto se se trata do arenito Caiuá das camadas Bauru (?) ou de solos de decomposição profundamente laterizados (vide “Geologia do Município de Lajes", 1932, p. 8). A fig. 13 representa o jazimento do arenito Caiuá sobre mesetas a sueste de Campo Mourão.

\section{D.3 - Rochas eruptivas mais recentes, ricas em sódio, na região do Paraná e Santa Catarina: rochas alcalinas de idade incerta $($ cretáceo $?)($ sinal $=$ Ki $)$}

No Paraná, as formações mesozóicas terminam, aparentemente, com o arenito Caiuá. Imediatamente sobre a seqüência total dos sedimentos jazem solos de decomposição mais recentes. Porém, em Santa Catarina, após o término das grandes efusões de lençóis básicos, efetuaram-se intrusões mais recentes com efusões vulcânicas de magmas ricos em sódio. Assim, as camadas gonduânicas no planalto de Santa Catarina, aproximadamente $9 \mathrm{~km}$ ao nordeste de Lajes, são atravessadas por tinguaitos e fonolitos, - descritos por Glycon de Paiva e Otávio Barbosa (1933) -, formando o stock do Morro do Tributo (fig. 67). Acompanhando o stock de fonolito, ocorrem diferenciações em diques e veios, como augitito, limburgito e monchiquito. Outras rochas nefelínicas, chonquinito (shonkinito), ijolito e jacupiranguito-piroxenito, romperam os granitos do complexo cristalino, pouco a oeste de Anitápolis. Provavelmente, as fontes termais (caldas) do litoral catarinense estão relacionadas com os rompimentos destas rochas alcalinas. 
No Paraná, além do gabro ("bocaiuvito" segundo GUTMANS, 1943) dos km 12 a 14,8 da estrada da Ribeira, o qual, em virtude da presença do anortoclásio, revela leve tendência alcalina, neste Estado até agora foram verificados apenas dois pequenos afloramentos de rochas alcalinas, a saber o aplito-granito de Santo Ignácio, em Curitiba, descrito por LEINZ (1937) como paisanito, e o sienito alcalino de Tuneiras mencionado por Paulino Franco de Carvalho e J. Menescal Campos (1937).

A idade geológica das rochas alcalinas brasileiras ainda é problemática. Djalma Guimarães (1933, 1943 e 1947) as descreve como produtos de diferenciação do magmamater gabróide-basáltico dos derrames de trapp do Paraná, indicando como idade o rético. Mesmo concordando com Djalma Guimarães no tocante às suas ótimas explanações sobre a origem e desenvolvimento dos magmas alcalinos chegamos a conclusões diferentes relativamente à sua idade geológica. A idade das rochas alcalinas é menos um problema químicofísico ou petrográfico do que uma questão puramente geológica. Intrusão e efusão dos magmas alcalinos não precisam, necessariamente, ter ocorrido em continuação imediata à formação das rochas do trapp do Paraná. Das pesquisas geológicas ressalta que os magmas gabróides basálticos ascenderam com a formação das fendas de tração. O rompimento dos magmas alcalinos, porém, observa-se relacionado aos efeitos de tensões tectônicas, por falhas, e à formação de chaminés de explosão vulcânica. Portanto, o vulcanismo mais antigo relaciona-se com movimentos tectônicotangenciais e o mais recente com movimentos tectônico-verticais. Conseqüentemente, encontram-se em primeiro plano de discussão os fenômenos geológicos, aos quais pode estar ligada a ascensão dos magmas foiaíticoteralíticos com suas rochas nefelínicas, melilitabasaltos, limburgitos e alnoitos, etc. A nosso ver, a ascensão dos magmas gabróides e basálticos e as efusões dos lençóis básicos estão ligadas à formação de fendas de tração em conexão com a separação da Terra de Gonduana, originalmente unida, e à formação da fenda atlântica, no início do jurássico. As injeções, rompimentos explosivos e efusões dos magmas alcalinos significam o fim dos gigantescos fenômenos vulcânicos, ocorridos durante $\mathrm{o}$ mesozóico, marcando o começo de movimentos tectônicos mais recentes resultantes de tensões da crosta que, por sua vez, iniciaram a fase eoandina da orogenia terciária. Em consideração destes fatos, as rochas alcalinas são antes postjurássico-cretáceas do que triássico-jurássicas.

Segundo nossa opinião, as rochas alcalinas de Santa Catarina pertencem à relação das ocorrências vulcânicas que, em Minas Gerais, formaram as chaminés de explosão com as mencionadas rochas alcalinas, altamente básicas, as quais ainda atravessam lençóis de picritoporfirito, derramados sobre os arenitos triássicos. Os tufos que acompanham estas rochas vulcânicas encontram-se sempre acima do arenito Areiado triássico (= Botucatu), enquanto que os preenchimentos das chaminés ainda contêm fragmentos de augita-porfiritos e rochas nefelínicas. Também na África do Sul, relacionaram-se as chaminés de explosão dos melilita-basaltos, limburgitos e kimberlitos, correspondentes às rochas eruptivas altamente básicas do oeste de Minas -, com o vulcanismo Stormberg jurássico e com os diabásios de Karru, considerando-os conseqüência imediata destes acontecimentos vulcânicos. Contudo, foi verificado que os kimberlitos do distrito de Heidelberg, na Terra do Cabo, atravessam camadas do cretáceo inferior que, no cretáceo superior, ainda sofreram perturbações tectônicas. Com isto foi constatado um grande espaço de tempo entre o vulcanismo Karru-Stormberg e a formação das chaminés (pipes) de explosões vulcânicas. Daí resulta o fato de que os melilitabasaltos e os kimberlitos ascenderam apenas no fim do mesozóico, ao iniciar-se o eo-terciário (paleoceno). Corresponde isto, a nosso ver, às condições do Brasil Central e Meridional. LAMEGO (1937 e 1945), pelos seus estudos detalhados sobre o maciço de foiaito do Itatiaia e em relação à ocorrência geológica de rochas alcalinas no Estado do Rio, chegou à mesma conclusão.

Incerta ainda é a posição do paisanito de Santo Ignácio em Curitiba. Como rocha alcalina, tratamo-lo, com reservas, neste capítulo. Tratase de aplito-granito leucocrático de textura porfírica evidente, mostrando fenocristais de ortoclásio sódico-bárico e de quartzo, contendo, além disso, hastingsita e aegirinta.

Sobre a idade geológica e intrusões do sienito de Tuneiras não existem, por enquanto, pesquisas detalhadas. Segundo as descrições de Menescal Campos, que menciona aegirina e arfvedsonita, 
parece tratar-se de um sienito alcalino. Como complemento à publicação de Otávio Barbosa (1933) sobre o stock de fonolito do morro do Tributo, mencionamos neste lugar apenas que, nos km 12 e 14, entre Lajes e Índios, não aflora fonolito, como indica o mapa (BARBOSA, 1933). Quanto à rocha cinza-esverdeada escura que ocorre entre Lajes e Índios, na frente sul do morro do Tributo, trata-se de uma rocha efusiva supersaturada, de caráter esferóide-riolítico, com $73,2 \%$ de $\mathrm{SiO}^{2}$, e rica em potássio $(8,8 \%)$. Visto que do morro do Tributo também são mencionados tinguaitos, deve-se notar que quartzo-tinguaito não entra em consideração, pois o teor em sílica é muito elevado e, além disso, são observados fenocristais de quartzo idiomorfos, claros. Segundo Rosenbusch, o quartzo ocorre apenas na massa fundamental dos quartzo-tinguaitos.

\section{E - ERA CENOZÓICA}

Com o início do cenozóico terminam, no Paraná e Santa Catarina, os períodos de sedimentações importantes. Segue-se uma época de acentuada erosão com formação da superfície atual. Até agora, não foram verificados sedimentos do terciário. Representa o terciário um período de movimentos tectônicos, equilibrando tensões da crosta terrestre, relacionadas com a fase andina da orogenia alpina que produziu falhas na orla continental, submergindo no mar a atual faixa litorânea do Brasil Meridional. Assim, o oceano Atlântico ingrediu nos vales de uma paisagem montanhosa cretáceo-terciária, formando as atuais baias de ingressão entre Paranaguá e Laguna (fig. 17 e 50). O peso do grande derrame eruptivo do período triássico-jurássico originou um encurvamento raso, isostático, ou depressão respectivamente, da bacia do Paraná. Durante a fase andina da orogenia alpina, nenhum dobramento perturbou os sedimentos gonduânicos, descansando sobre o escudo gnáissico Brasilia. Isto significa que não existiu um efeito de pressão de leste contra o continente sul-americano, mas que apenas a resistência frontal da antiga bacia pacífica contra as massas movimentadas pela força centrífuga e conseqüente afastamento do pólo, em virtude da rotação oeste para leste, originou o amontoamento e abaulamento, ou dobramento respectivamente, da crosta siálica.
O tectonismo de falha pode ter começado no fim do cretáceo, ascendendo, com estes acontecimentos, magmas alcalinos. Porém, desenvolveu-se particularmente no terciário, originando o falhamento da borda oriental do continente. Diferenças notáveis de nível nas falhas são apenas observadas na Serra do Mar, ao longo das falhas longitudinais (fig. 1, 6, 20, 21 e 24). O grande número das falhas transversais que desaparecem sucessivamente para o interior do continente, revelam sempre pequenas diferenças de nível entre as bordas. A acumulação das pequenas diferenças de níveis de alguns metros, nas numerosas falhas transversais e a sua disposição escalonada, numa leve inclinação geral para SW, produziu, em 100 $\mathrm{km}$ de extensão na frente $\mathrm{NE}-\mathrm{SW}$, já diferenças de altitudes de várias centenas de metros entre os afloramentos mais ao norte e mais ao sul de uma certa camada. Deste modo explica-se o fato de observar camadas de carvão da série Tubarão, situadas na parte média da Serra Geral acima de 1000 m s. n. m., no sul de Santa Catarina a apenas 40 a $60 \mathrm{~m}$ acima e mesmo até $200 \mathrm{~m}$ abaixo do nível do mar. As falhas longitudinais, em frente da escarpa do planalto do interior, são dirigidas de $\mathrm{N} 60^{\circ} \mathrm{E}$ e $\mathrm{N} 20-25^{\circ} \mathrm{E}$ e, em alguns casos, diretamente $\mathrm{N}-$ S. o sistema das falhas transversais apresenta, regularmente, os rumos $\mathrm{N} 75^{\circ} \mathrm{W}$ e $\mathrm{N} 20-45^{\circ} \mathrm{W}$ (azimutes magn. $=\mathrm{N} 290^{\circ}, 320^{\circ}$ e $340^{\circ} \mathrm{W}$ ). Em virtude das direções divergentes das falhas que se cruzam, formam-se freqüentemente pequenos blocos em forma de cunha (Keilschollen) (fig. 116 a 119). Alguns esboços elucidam a disposição do tectonismo de falha (fig. 14).

\section{E.1 - O Quaternário $($ sinal $=\mathbf{Q P}, \mathbf{Q m}$ e Qc)}

Enquanto que nos períodos cretáceo e terciário falta sedimentação positiva, na região do Paraná e Santa Catarina, sendo caracterizados estes períodos particularmente por movimentos tectônicos como falhamento na borda continental, seguidos por modificações de níveis epirogênicas, iniciam-se, no quaternário, novamente extensos depósitos de detritos e de material de desagregação de rochas. O cretáceo e o terciário são especialmente distinguidos pelas enormes eversões do complexo cristalino, as quais causaram, entre a Serra do Mar e a 
borda das camadas de sedimentos paleozóicos, o abaixamento do peneplano paleozóico, isento de sedimentos, formando $o$ atual nível de denudação do primeiro planalto do Paraná. O plano de denudação deste planalto que corta entre $850 \mathrm{~m}$ e $950 \mathrm{~m}$ s. n. m. o complexo cristalino (fig. 15 e 28) trunca, como nível mais recente, também o complexo cristalino do Estado de São Paulo. Os planaltos dos dois estados são separados pelo profundo vale do rio Ribeira e transformados, pela erosão marginal, numa região montanhosa recente (fig. 15 e 28 a 31).

A perfeita formação deste plano de denudação recente entre $850 \mathrm{~m}$ e $950 \mathrm{~m} \mathrm{~s}$. n. m. lembra um peneplano, particularmente nas zonas onde falta a borda mais elevada do complexo cristalino da Serra do Mar ou no pedestal da cuesta devoniana.

No primeiro planalto do Paraná, jazem sedimentos argilosos, lacustres, do quaternário antigo (sinal QP), com um faixa lateral de seixos fluviais e pedregulhos em bancos e lentes (fig. 122), como também sedimentos fluviais antigos. Estes sedimentos estendem-se especialmente na zona urbana e nos arredores de Curitiba, entre Atuba e Campo Largo e para o sul até as várzeas recentes do rio Iguaçu, na estrada Curitiba Araucária. Os sedimentos lacustres, pleistocenos, são mencionados na literatura geológica, freqüentemente, como depósitos neoterciários (OLIVEIRA, 1927 A) e (OLIVEIRA e LEONARDOS, 1943) sem que, entretanto, tenha sido aduzida uma prova à sua idade terciária. Terraços de seixos e pedregulhos do quaternário antigo acham-se conservados, em diminuta extensão, no vale do rio Ivaí, abaixo da corredeira de Ferro e nos terraços e planícies de vale mais altas do rio Iguaçu (formação Cacimbas). Nos antigos depósitos do vale do rio Iguaçu, diante da escarpa triássico-jurássica, foram encontrados na formação Cacimbas, em Porto União, nos anos de 1934 e 1947, esqueletos de Megatherium, um totalmente transformado em vivianita e guardado pelo Museu Nacional e outro em preparação para o Museu Paranaense.

Também a formação do vale do Alto Paraná com extensas planícies de aluvião, com muitas ilhas, e as formas morfológicas do cañon abaixo das Sete Quedas com os recentes saltos nos paredões do cañon ou nas barrancas dos afluentes, levam à concepção de que o vale do rio Paraná com seus grandes saltos se tenha formado apenas durante e depois do quaternário antigo. Segundo o maior ou menor volume de água, os saltos situam-se diretamente na borda do cañon ou dela afastados 1 a $4 \mathrm{~km}$. As majestosas cataratas do rio Iguaçu, porém, encontram-se $21 \mathrm{~km}$ rio acima, num vale de foz entalhado em forma de cañon. As massas d'água precipitam-se sobre dois degraus formados por lençóis de diabásio e meláfiros com drusas. No degrau maior, o rio Iguaçu despenca $69 \mathrm{~m}$ para a garganta do Diabo, enquanto que o degrau menor, acima do salto principal, tem apenas uma altura de 2,50 m (fig. 46). As antigas várzeas e planícies de vale do rio Paraná, que acompanham o cañon no lado leste, atualmente acham-se recortadas por afluentes recentes, transversais, de modo que estes antigos vales estão situados agora 10 a 24 m sobre o nível dos talvegues daqueles tributários (fig. 12).

Como formações do quaternário antigo mencionamos ainda os enormes amontoados de blocos (Blockhalden) da Serra do Mar, originados pela desagregação mecânica dos paredões (mechanische Wandverwitterung) e os rompimentos de núcleo dos grandes matacões graníticos. Estas formações, atualmente sob uma camada de terra de decomposição recente, com densa mata pluvial, apenas podem ser explicadas por forte insolação e acentuados contrastes de temperatura. Sob as influências atuais do clima úmido, quente-temperado, do litoral, com formas de superfície causadas predominantemente pela decomposição química, não podem resultar nem os enormes amontoados de blocos e nem os matacões com rompimentos de núcleo (Kernsprünge), nem os fenômenos de desagregação mecânica. Todas estas formas antigas, em conseqüência da decomposição química e formação de solos, acham-se hoje encobertas por um manto de vegetação. As formas fundamentais e amontoados de blocos e detritos (Block-Schutthalden) da Serra do Mar no Paraná originaram-se numa época de clima semi-árido do quaternário antigo, enquanto que atualmente predominam, na paisagem da Serra do Mar, decomposição química, lavagem pluvial e desmoronamentos (fig. 120 e 121).

A sedimentação do quaternário recente dos planaltos do interior (sinal Qc) é particularmente caracterizada pela formação dos extensos campos de inundação, denominados várzeas (fig. 38, 39 e 123), com sedimentos fluviais, 
depósitos de seixos (fig. 122), planícies arenosas, pantanais e formações de lagoas (fig. 126). Sejam mencionados ainda aqui os solos de decomposição recentes e originados climaticamente, especialmente as terras vermelhas e roxas e os solos ácidos, pretos, de pântanos dos planaltos. Incrustações de superfície antigas (denominadas canga) e fanglomerados ainda conservados em alguns pontos sob terras vermelhas, como, por exemplo, ao sudoeste de Ponta Grossa, leste de Piraí e em Serrinha, igualmente são tidos como formações de solos do quaternário antigo, originados pelo clima semi-árido. De efeito muito notável, sob as condições climáticas atuais, são as enxurradas nos solos desprovidos de vegetação, particularmente ao longo dos trilhos das carroças nas estradas (fig. 124). Já após alguns períodos de chuva, se formam barrancos (voçorocas) tão profundos que em nada faz lembrar a estrada que antes existia (fig. 125).

$\mathrm{Na}$ zona litorânea, a sedimentação quaternária recente (sinal Qm) causa, em conseqüência das ascensões epirogênicas, um deslocamento negativo de praia, com formação das vastas planícies arenosas ou pantanosas, restingas (Strandwälle), campos de dunas e cordões litorâneos com lagunas desligadas do mar. Terra a dentro, as planícies, entulhadas pela sedimentação marinha e terrestre, já estão cobertas pela mata, avançando aqui a sedimentação terrestre sobre os depósitos marinhos. Segue-se, então, uma zona de faixas paralelas com planícies pantanosas e tabuleiros arenosos com restos de moluscos. Nesta zona, desenvolveu-se a vegetação típica de restinga, influenciada principalmente pelos solos arenosos pobres e pelos ventos salinos do oceano. Revela, por conseguinte, uma mescla singular de formas xerófitas, halófitas e higrófitas da zona climática tropical e subtropical, mistura que dá a esta associação florística um cunho muito particular.

Como zona de sedimentação mais recente encontra-se, nas baias, a orla de manguezal (fig. 132) e, em frente ao oceano, a praia arenosa, despida, seguida pela formação Pés-Caprae além do cliff arenoso (nip) ou da restinga (Strandwall) ou pelo campo de dunas (fig. 53, 129 e 133). O manguezal ocupa ainda grandes áreas do lado do continente nas reentrâncias da ilha de Santa Catarina. Mais para o sul, o manguezal desaparece logo no litoral brasileiro. Os últimos vestígios do mangue são observados na foz do rio Araranguá. Os mangues com suas raízes suportes (Rhizophora mangle) e a Avicennia tomentosa (Avicennia Schauriana) com seus pneumatóforos, erguidos do lodo, constituem menos elementos ativos para a sedimentação positiva do que a região peculiar da vida dos pequenos animais marinhos. Pelo transporte de material em suspensão pelos rios costeiros, e pela rápida precipitação, quando em contato com a água salgada, formam-se bancos de lodo sub-aquáticos, conquistados pelo mangue. Em virtude da sedimentação acumulativa, os bancos de lodo do mangue, sucessivamente, são entulhados por areia, morrendo o mangue ou emigrando diante da faixa de areia em direção à água salgada da baia, onde ocupa novos bancos de lodo, sendo despojado sempre de novo de sua esfera vital do lado detrás pelo entulhamento de areia progressivo.

Nas ilhas das baias, nas antigas restingas ou nas planícies arenosas, e nas ilhas rochosas das baias ou lagoas antigas, atualmente entulhadas, encontram-se notáveis amontoados de conchas com 5 a $12 \mathrm{~m}$ de altura, originados pela atividade humana e denominados sambaquis. Dispensando explicações detalhadas, mencionamos somente que estes sambaquis representam formas maiores do que os Kjoekknmoeddinger da idade da pedra na Europa (fig. 130 e 131). Entre os objetos de uso humano, encontrados nos sambaquis, não se acham formas paleolíticas, representando todos os utensílios, de pedra ou osso trabalhados, tipos neolíticos que devem ser de idade relativamente recente.

Resumindo indicamos para o Paraná e Santa Catarina as seguintes formas de sedimentação quaternária:

b) Quaternário recente (holoceno ou alúvio)

8. Solos de decomposição recentes, originados climaticamente, mormente terras vermelhas, sem ou apenas com uma fina crosta de húmus e, secundariamente, solos de pântanos, pretos e ácidos; formações de lagoas nos campos (Pfannenbildungen);

7. Sedimentação fluvial, entulhamento dos vales dos rios e formação de várzeas com pântanos e terraços fluviais;

6. Sambaquis, amontoados recentes de conchas originados pela atividade humana; 
5. Planícies arenosas da costa com lagunas abertas ou pantanais e formações de cordões litorâneos com dunas eólicas;

4. Formação de cliffs, cavas de ressaca e planos de abrasão em diferentes altitudes sobre o nível do mar, entre $1,30 \mathrm{~m}$ e $102 \mathrm{~m}$ e níveis de erosão até $220 \mathrm{~m}$ como indícios de ascensões epirogênicas desde o quaternário antigo;

a) Quaternário antigo (pleistoceno ou dilúvio)

3. Amontoados de blocos grandes e seixos (Schutthalden) resultantes da desagregação mecânica de rochas, que indicam um clima semi-árido para uma época do quaternário antigo, ainda não determinada, atualmente entulhados por solos de decomposição recentes e cobertos por uma exuberante mata pluvial;

2. Fanglomerados ou crostas de limonita sob terras vermelhas recentes (depósitos de canga) como incrustações antigas da superfície durante um clima semi-árido no quaternário antigo;

1. Depósitos argilo-arenosos de depressões ou bacias com faixas de seixos e pedregulhos e terraços fluviais (formação Curitiba e Tamanduá), várzeas antigas e terraços fluviais elevados (formação Cacimbas em União da Vitória).

\section{CONCLUDING REMARKS}

The lack of a long-needed new presentation of the geology of the States of Paraná and Santa Catarina, in the light of the most recent investigations and surveys, cannot be filled by the present summary. For this reason, an amplification of the text of the present work has been made, which treats the Archean and Algonkian, in particular, more thoroughly, as basic features of the geology of Paraná and Santa Catarina. With these basic features are also included surveys of the useful minerals and of the fossils hitherto known to be contained in the individual formation. A great number of tables, figures, sections and maps explain the text, which will appear in Portuguese, English and German as a supplementary volume of the "Ärquivos de Biologia e Tecnologia" in Curitiba.

This supplementary volume includes a bibliography, which has been made as complete as possible.

\section{ZUSAMMENFASSUNG}

Die vorliegende kurze Übersicht zur Geologie der Staaten Paraná und Santa Catarina wurde als Begleittext zur Skizze für die Revision der GEOLOGICAL MAP OF SOUTH AMERICA verfasst. Sie enthält die Ergebnisse der geologischen Forschung bis zum Jahre 1947 in gedrängtester Form, wobei auf Einzelheiten nicht eingegangen wird. Auf ausdrücklichen Wunsch sind die Vorkommen nutzbarer Mineralien in der Übersicht nicht berücksichtigt, und auch das Literatur-Verzeichnis auf das Äusserste eingeschränkt worden.

Da der Verfasser im Hinblick auf die Neugliederung der Gondwana-Schichten die Serie Passa Dois etwas eingehender behandelte, mussten dafür Archaeikum und Algonkium auf das Mindestmass gekürzt werden. Das war dadurch möglich, dass bei den mannigfachen Einzelheiten der Erscheinungen im kristallinen Komplex diese bei dem für die geologische Karte vorgesehenen Masstab doch nicht dargestellt werden konnten. Die Neugliederung der geologischen Baustoffe von Paraná und Santa Catarina ist in der stratigrafischen Tabelle $\mathrm{n}^{\mathrm{o}} 2$ zusammengefasst und wird durch die beigefügten Skizzen erläutert.

\section{SCHLUSSBEMERKUNG}

Der Mangel einer längst notwendig gewordenen neuen Darstellung der Geologie der Staaten Paraná und Santa Catarina nach dem neuesten Stand der Untersuchungen und Aufnahmen kann durch die vorliegende Übersicht nicht behoben werden. Es ist aus diesem Grumde eine Erweiterung des Textes der vorliegenden Arbeit angefertigt worden, die als Grundzüge der Geologie von Paraná und Santa Catarina besonders Archaeikum und Algonkium ausführlicher behandelt. Diesen Grundzügen werden auch Übersichten über die nutzbaren Mineralien und über den bisher bekannt gewordenen Fossilinhalt der einzelnen Formationen beigefügt. Eine grosse Anzahl von Tabellen, Figuren, Profilen und Karten erläutert den Text, der in portugiesischer, englischer und deutscher Sprache als Ergänzungsband der "Arquivos de Biologia e Tecnologia" in Curitiba erscheinen wird. 
Diesem Ergänzungsband ist ein LiteraturVerzeichnis beigefügt, das so vollständig als möglich angefertigt wurde.

\section{REFERÊNCIAS}

\section{A) PARANÁ}

ClARKE, J. M. (1913), Fósseis devonianos do Paraná. Serviço Geológico e Mineralógico do Brasil, Rio de Janeiro, Monografia I.

COWPER REED, F. R. (1928), Faunas triássicas do Brasil. Serviço Geológico e Mineralógico do Brasil, Rio de Janeiro, Monografia IX. 97 p., 5 ests.

GUIMARÃES, Djalma (1933), A província magmática do Brasil Meridional. Departamento dos Serviços Geográfico e Geológico de Minas Gerais, Belo Horizonte, Monografia $\mathrm{n}^{\circ} 1,65 \mathrm{p}$.

HOLDHAUS, Karl (1919), Sobre alguns Lamellibranchios fósseis do Sul do Brasil. Serviço Geológico e Mineralógico do Brasil, Rio de Janeiro, Monografia II. 24 p., 2 pls.

LANGE, Frederico Waldemar (1942), Restos vermiformes do "Arenito das Furnas". Arquivos do Museu Paranaense, Curitiba, 2 (artigo 1) : 3-8.

LANGE, Frederico Waldemar (1943), Novos fósseis devonianos do Paraná. Arquivos do Museu Paranaense, Curitiba, 3 : 215-231.

LEINZ, Viktor (1937), Estudos sobre a glaciação Permo-carbonífera do Sul do Brasil. Bol. do Departamento Nacional da Produção Mineral, Rio de Janeiro, (21) : 47, 12 ests.

MAACK, Reinhard (1941), Algumas observações a respeito da existência e da extensão do arenito superior São Bento ou Caiuá no Estado do Paraná. Arquivos do Museu Paranaense, Curitiba, 1 : 107129.

MAACK, Reinhard (1946a), Geologia e geografia da região de Vila Velha, Estado do Paraná, e considerações sobre a glaciação carbonífera no Brasil. Arquivos do Museu Paranaense, Curitiba, $\mathbf{5}: 305$, com perfis, esboços, figuras e fotos.

MAACK, Reinhard (1946b), Notas preliminares sobre uma nova estratigrafia do devoniano do Estado do Paraná. Tese $\mathrm{n}^{\mathrm{o}} 46$ apresentada ao $2^{\circ}$ Congresso Pan-Americano de Engenharia de Minas e Geologia, Rio de Janeiro.

MENDES, Josué Camargo (1945), A série Estrada Nova no Norte do Paraná. Anais da Academia de Ciências, 17 (3) :209-217.

OLIVEIRA, Euzébio Paulo de (1927), Geologia e recursos minerais do Estado do Paraná. Serviço Geológico e Mineralógico do Brasil, Rio de Janeiro, Monografia VI. 172 p., fotos e mapas.

PASSOS, Nero; AMARAL, J. C. do; ODDONE, Décio S.; ALVES, José; DUTRA, E. Bourdet; LEINZ, Viktor; PAIVA, Glycon de; PAULO,
Alderico R. de e DECOURT, Ralfo R. (1940), Carvão mineral de Barra Bonita e Carvãozinho (Estado do Paraná). Bol. do Departamento Nacional da Produção Mineral, Rio de Janeiro, (42).

\section{B) SANTA CATARINA}

CARVALHO, Paulino Franco de (1938), reconhecimento geológico no Estado de Santa Catarina. Bol. do Serviço Geológico e Mineralógico do Brasil, Rio de Janeiro, (92) : 30, 37 ilus., 1 mapa.

COWPER REED, F. R. (1929), Novos phyllopodos fosseis do Brasil. Bol. do Serviço Geológico e Mineralógico do Brasil, Rio de Janeiro, (34) : 17, 1 mapa.

COWPER REED, F. R. (1930), Uma nova fauna Permo-carbonifera do Brasil. Serviço Geológico e Mineralógico do Brasil, Rio de Janeiro, Monografia X.

FREITAS, Ruy Ozório de (1945), O conglomerado do Baú. (Série Itajaí - Santa Catarina). Bol. de Geologia da Faculdade de Filosofia, Ciências e Letras da Universidade de São Paulo, 50 (2) : 37115 , com figs. e fotos.

MAACK, Reinhard (1937), Geographische und geologische Forschungen in Santa Catarina (Brasilien). - Ergänzungsheft V zur Zeitschrift der Ges. f. Erdkunde, Berlim. p. 1-85, 2 mapas, 7 esboços e 24 fotos.

OLIVEIRA, Euzébio Paulo de (1918), Regiões carboníferas dos Estados do Sul. Bol. do Serviço Geológico e Mineralógico do Brasil, Rio de Janeiro. 125 p. e mapa.

OPPENHEIM, Viktor (1934), Rochas Gondwánicas e Geologia do Petróleo do Brasil Meridional. Bol. do Departamento Nacional da Produção Mineral, Rio de Janeiro, (5) : 129, 29 fls., 7 mapas.

ROCHA, José Fiuza da e SCORZA, Evaristo Pena (1940), Estratigrafia do carvão em Santa Catarina. Bol. do Departamento Nacional da Produção Mineral, Rio de Janeiro, (104) : 162, com ests. e 34 figs.

WHITE, I. C. (1908), Relatório final da Comissão de Estudos das Minas de Carvão de Pedra do Brasil, Rio de Janeiro. 617 p., 14 ests., ilus. e mapas.

\section{C) BIBLIOGRAFIA GERAL}

BRANNER, J. C. (1919), Outlines of the Geology of Brazil to accompany the Geological Map of Brazil. Bulletin of Geological Society of America, New York, 30 (2) : 189-338, ilus. e mapa.

GUTMANS, M. (1943), Rochas-Mater da "TERRA ROXA". Brangantia, Campinas, (3) : 271-322, 5 ests. Instituto Agronômico. 
LAMEGO, Alberto Ribeiro (1938), O massiço de Itatiaya e regiões circundantes. Bol. do Serviço Geológico e Mineralógico do Brasil, Rio de Janeiro, (88) : 93, 43 ilus., 1 mapa.

MENDES, Josué Camargo (1944), Lamelibrânquios triássicos de Rio Claro (Estado de São Paulo). Bol. de Geologia da Faculdade de Filosofia, Ciências e Letras da Universidade de São Paulo, 45 (1) : 4174, 3 esboços, 2 ests.

MENDES, Josué Camargo (1945), Considerações sobre a estratigrafia e idade da formação Estrada Nova. Bol. de Geologia da Faculdade de Filosofia, Ciências e Letras da Universidade de São Paulo, 50 (2) : 27-34, 4 figs.

OLIVEIRA, Avelino Ignácio de e LEONARDOS, O. H. (1943), Geologia do Brasil. 2. ed. Rio de Janeiro.

PAES LEME, A. Betim (1943), História física da Terra. Rio de Janeiro. 1020 p. 


\section{FIGURAS}

\section{1 a 135}

Brazilian Archives of Biology and Technology 


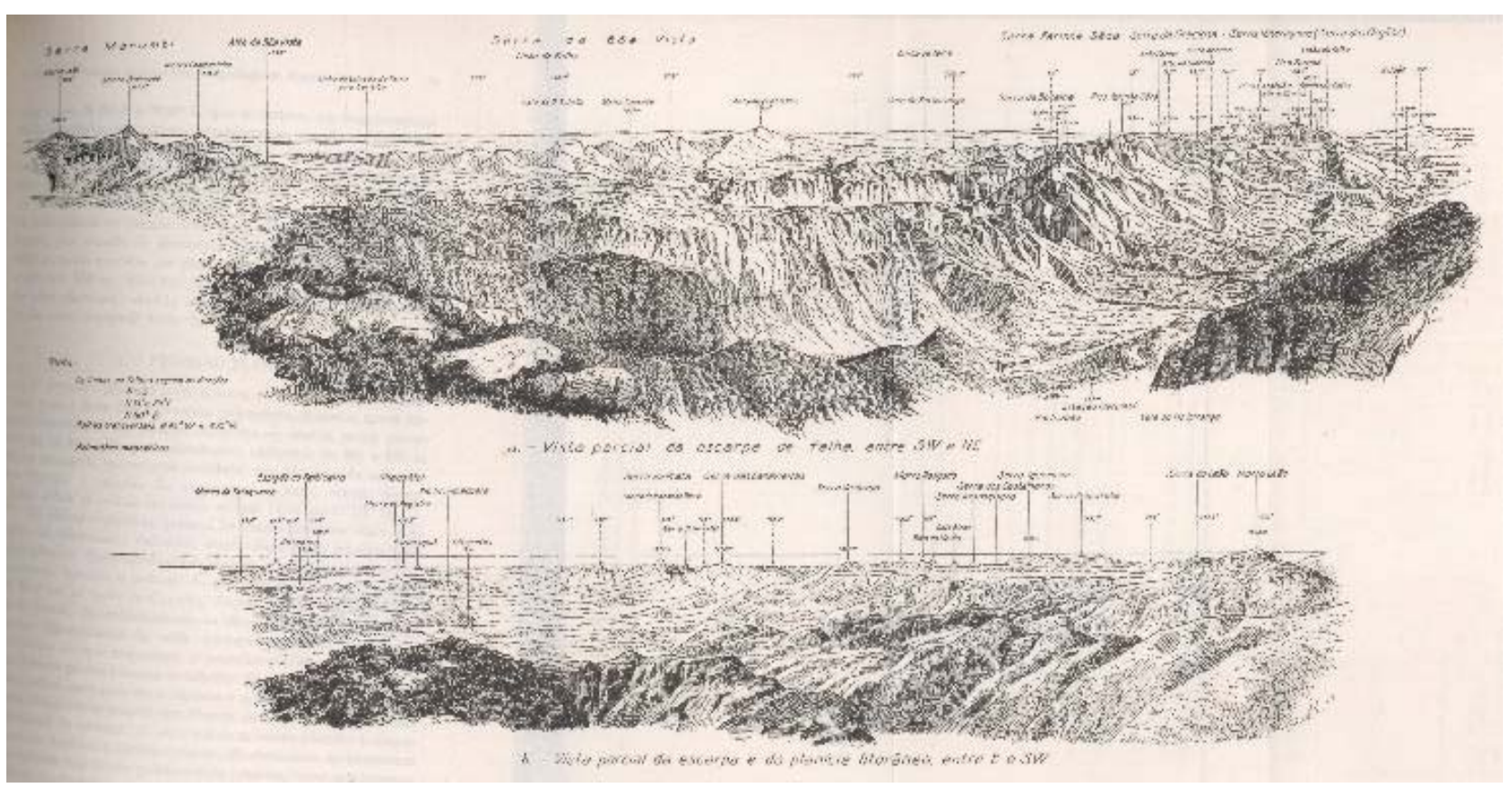

Fig. 1 - Panorama da Serra do Mar no Estado do Paraná, tomado do Pico do Marumbi, a 1547 m de altitude s.n.m. por Reinhard Maack, Engenheiro Geólogo. Paraná.

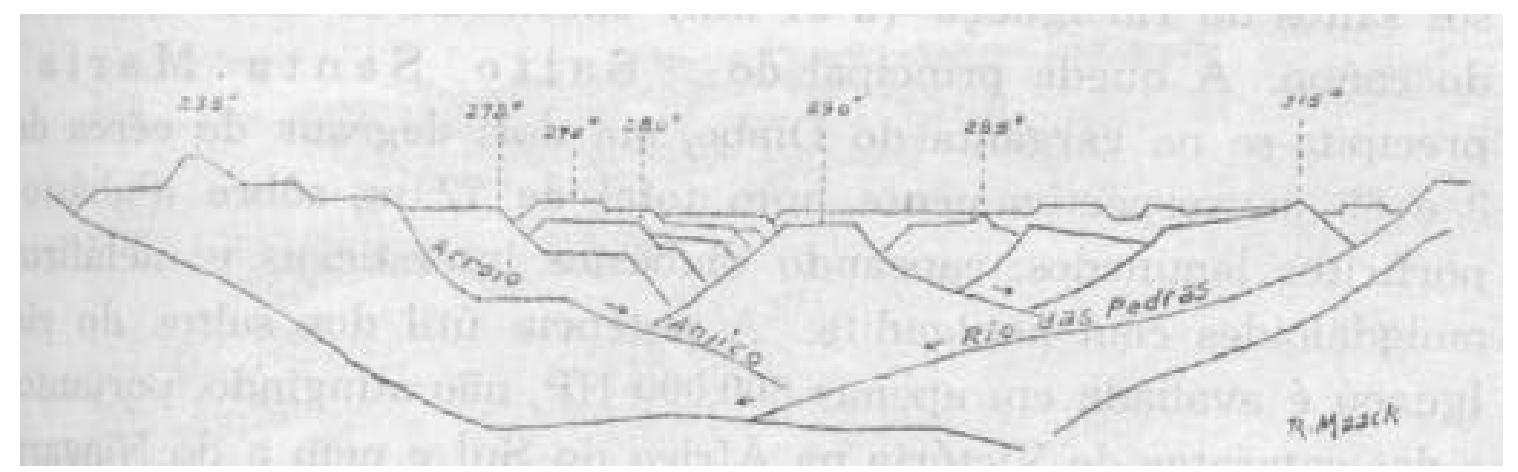

Fig. 2 - Formas de mesetas no terceiro planalto do Estado do Paraná na região dos vales dos rios Pedras e Taquaruçú. Paraná. 


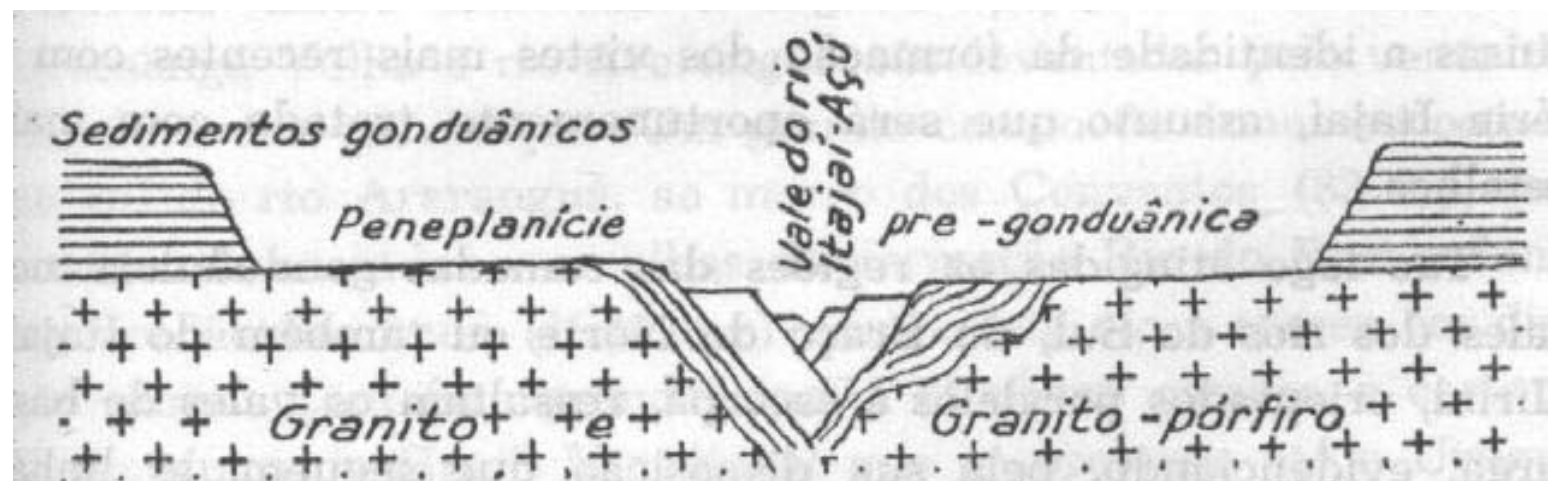

Fig. 3 - A peneplanície pré-gonduânica desnudada, no vale do rio Itajaí - Açu. Vista do km 27,5 em Subida. Paraná.

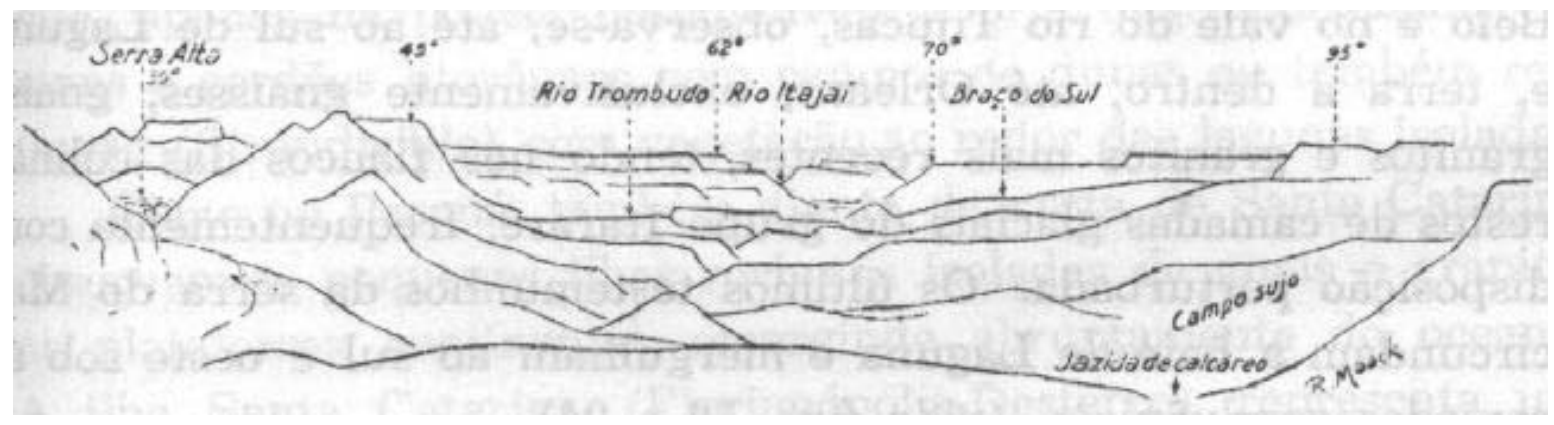

Fig. 4 - Vista do Km 46,5 a oeste da Serra Alta sobre os vales dos Rios Trombudo e Braço do Sul, mostrando as formas de plateaus e mesetas das rochas gonduânicas. Paraná.

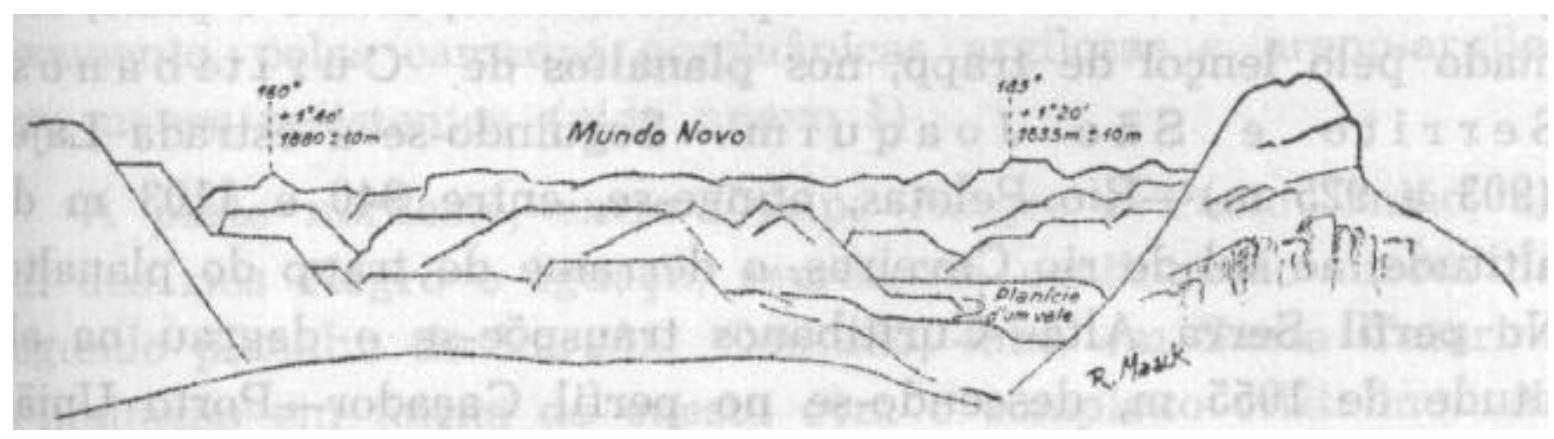

Fig. 5 - Vista do morro do Panelão em direção sul sobre as maiores elevações em forma de platôs da Serra Geral. Paraná. 


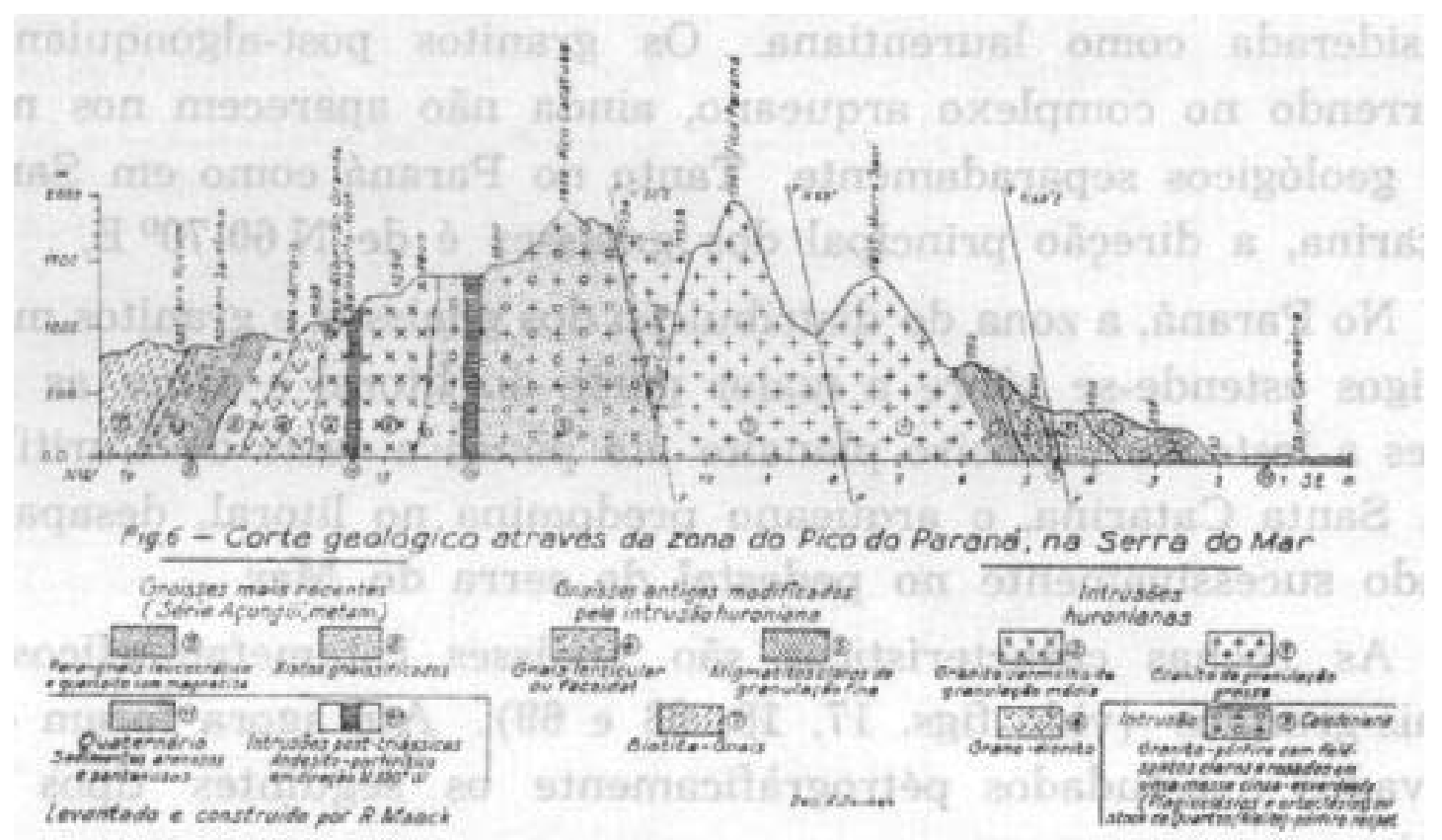

Fig. 6 - Corte geológico através da zona do Pico Paraná na Serra do Mar. Paraná.

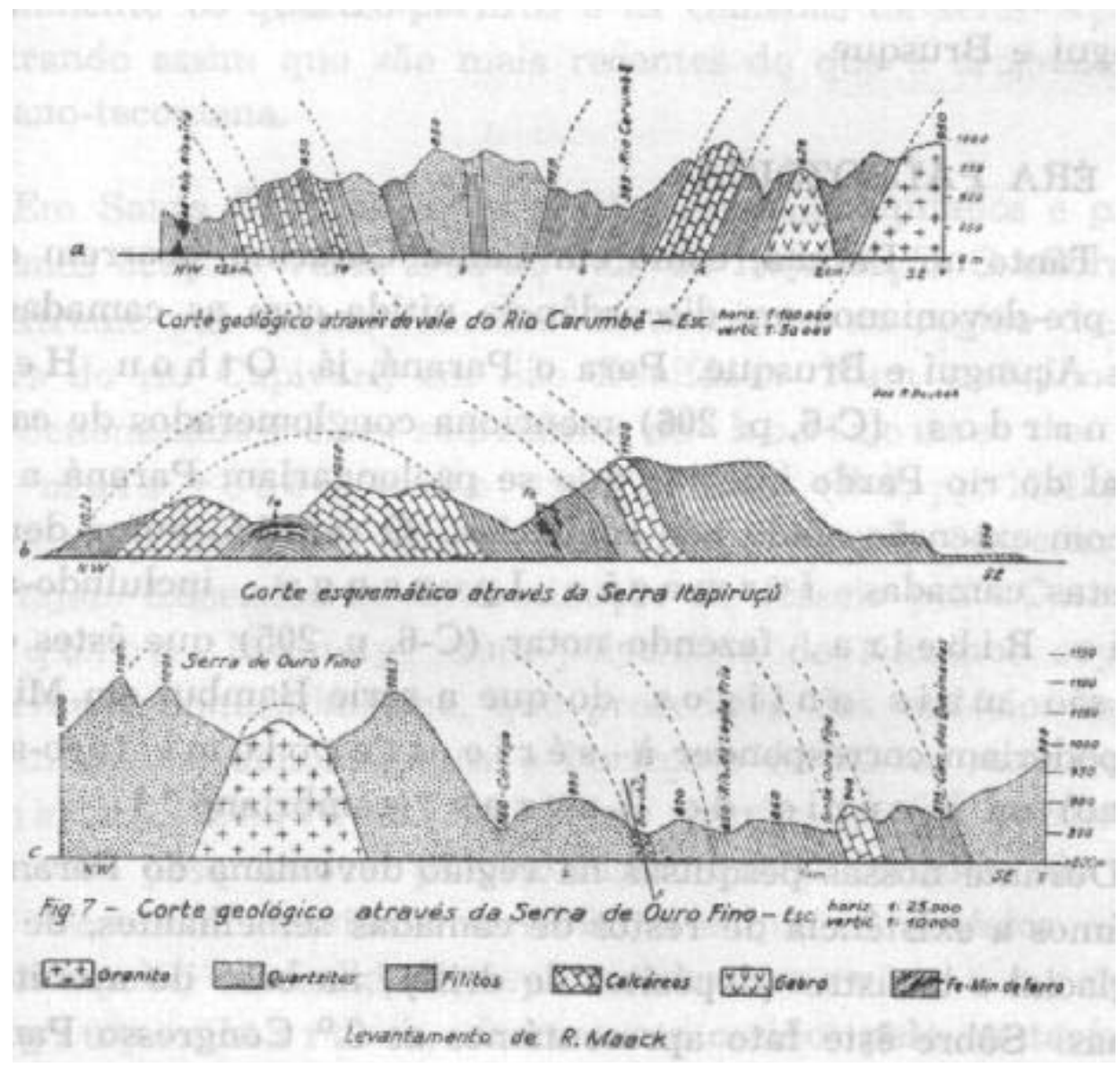

Fig. 7 - Cortes geológicos através das camadas da série Açunguí. Paraná. 


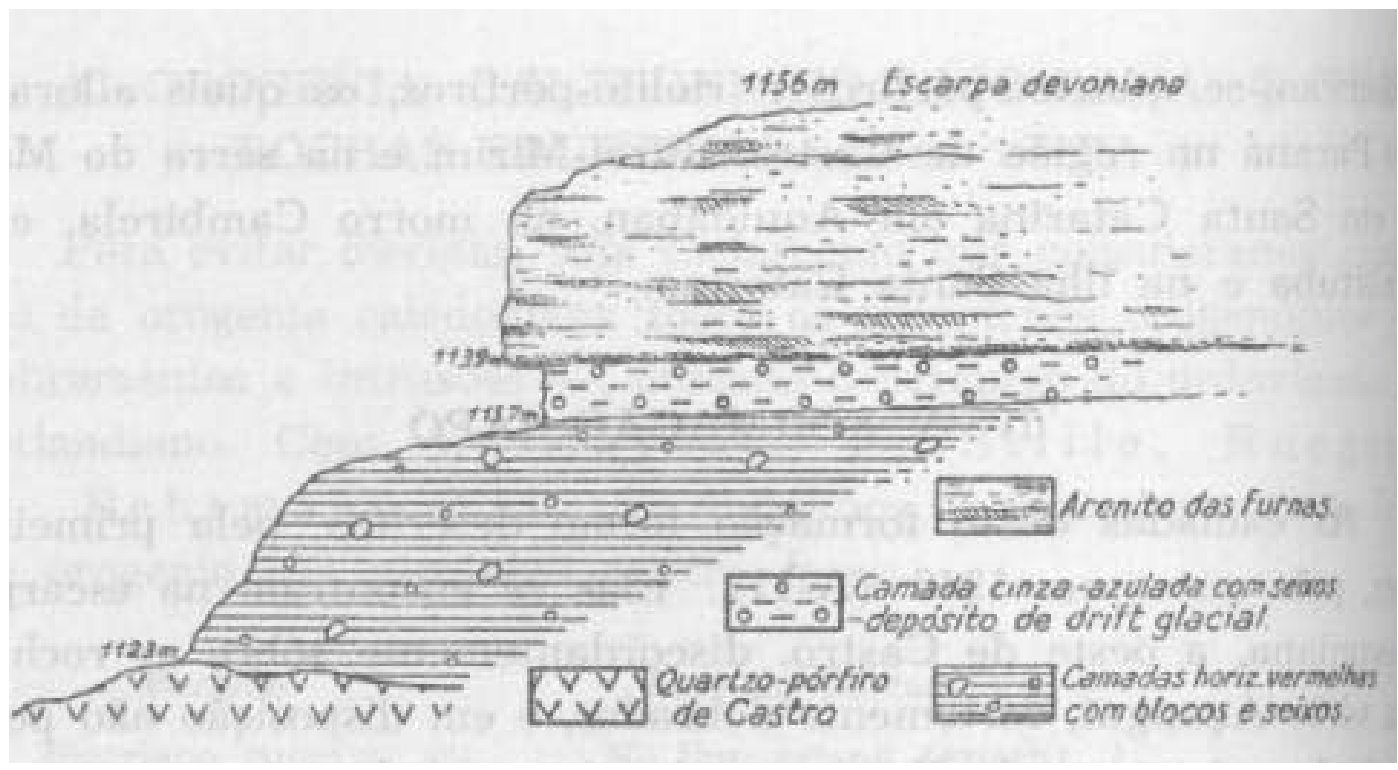

Fig. 8 - Esboço do afloramento das camadas flúvio-glaciais pré-devonianas na Serra São Joaquim. Paraná.

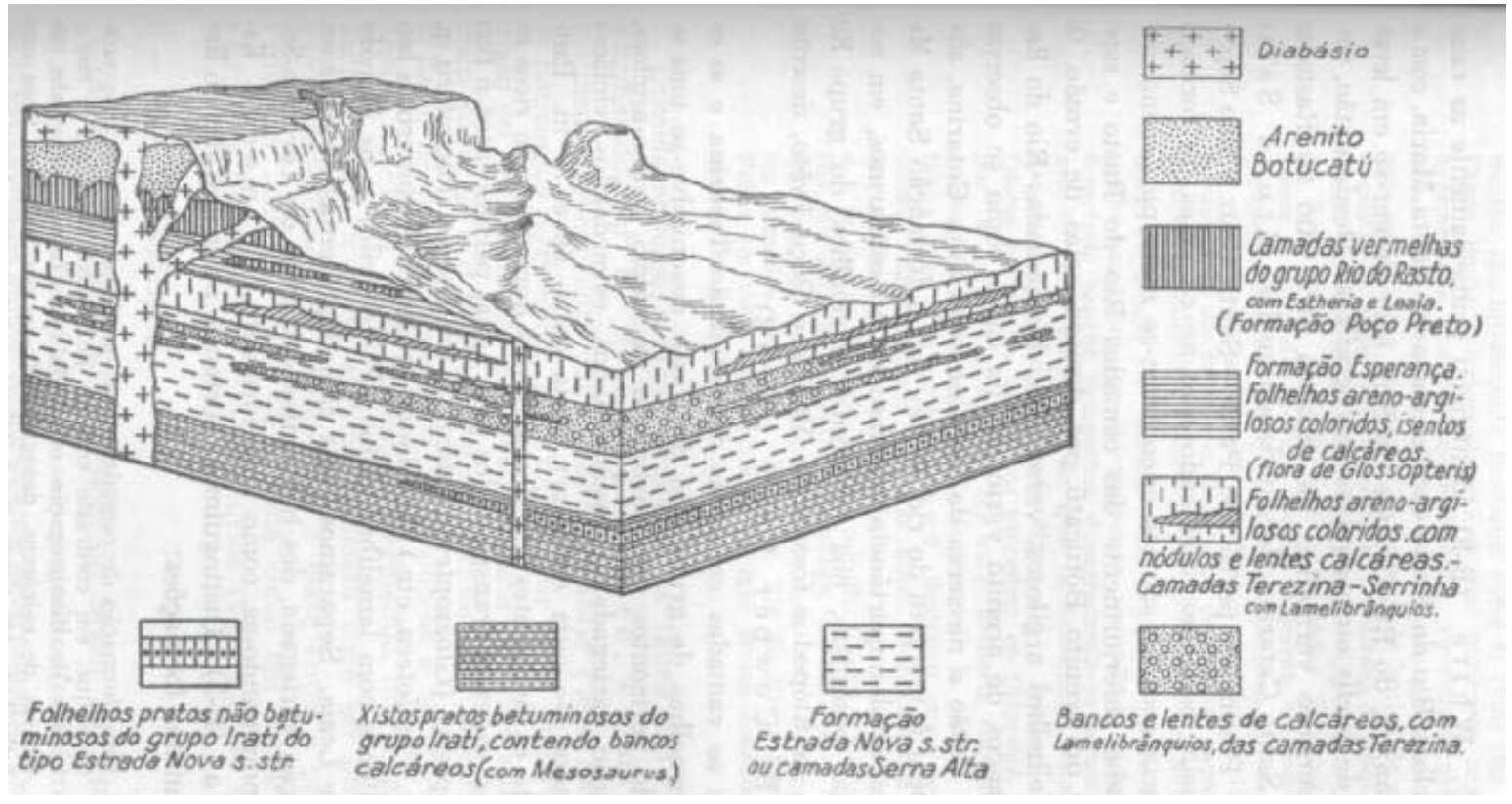

Fig. 9 - Esquema das relações estratigráficas (Schichten-Verband ou LagerungsVerhältnisse) entre as camadas das séries Passa Dois (permiano) E São Bento (triássico-jurássico). Paraná. 


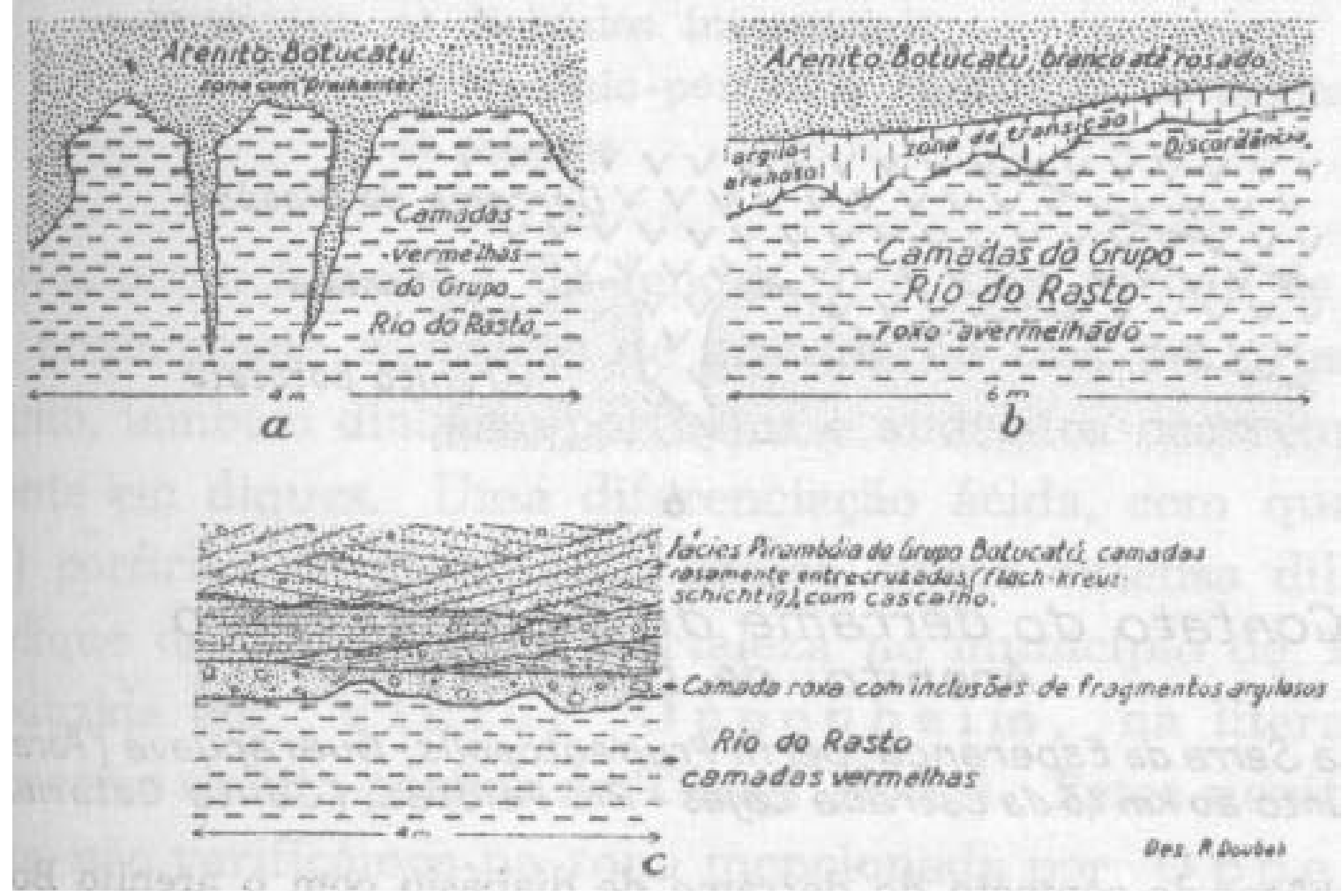

Fig. 10 - Esboços do contato das camadas vermelhas, Rio do Rasto com o Arenito Botucatu. Paraná. 


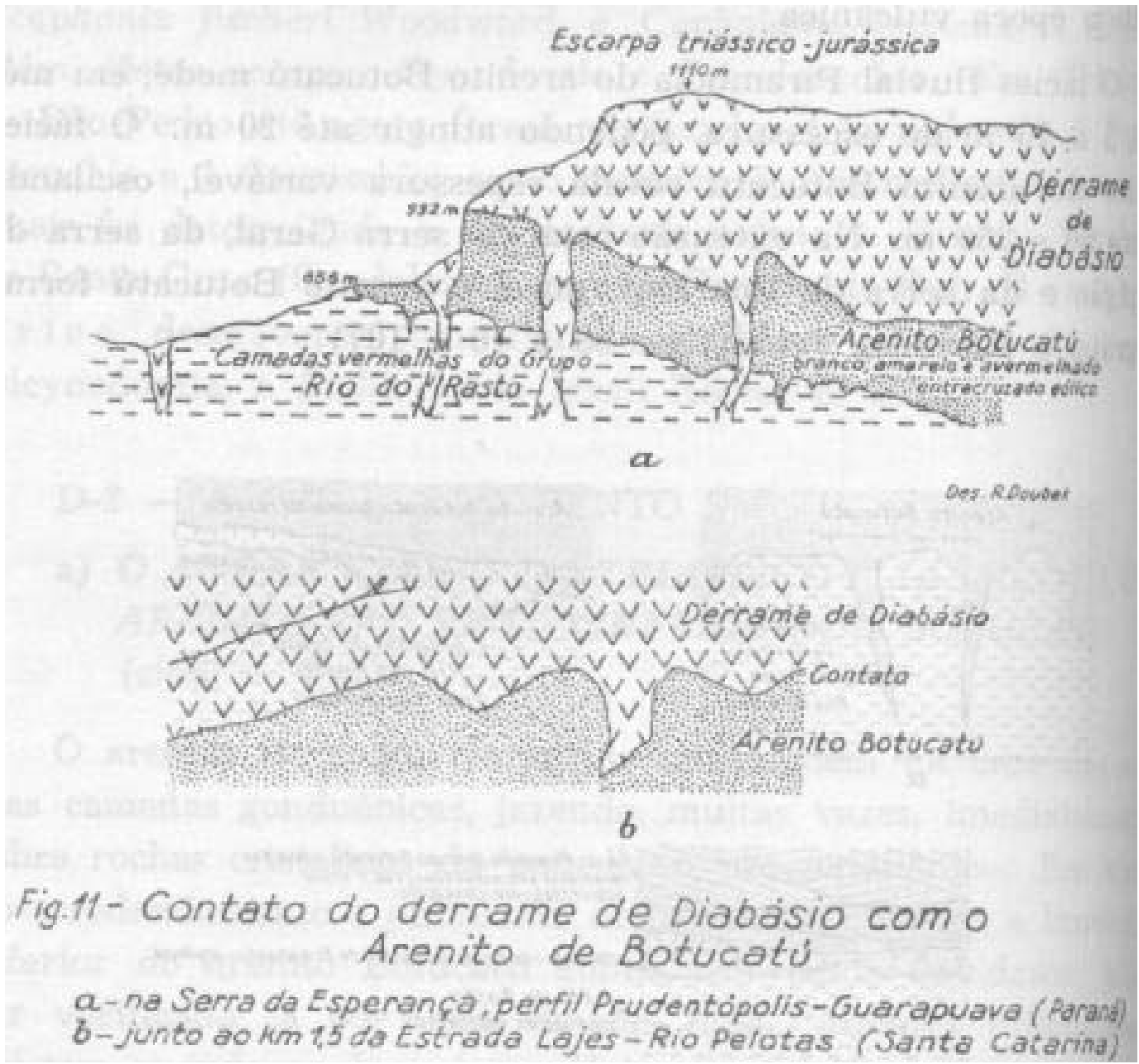

Fig. 11 - Esboços do contacto do derrame de diabásio com o arenito Botucatu. Paraná.

a) corte da frente da Serra da Boa Esperança no perfil Prudentópolis Guarapuava (Paraná)

b) capa eruptiva básica sobre o arenito Botucatu no km 1,5 ao sul de Lajes (Santa Catarina) 


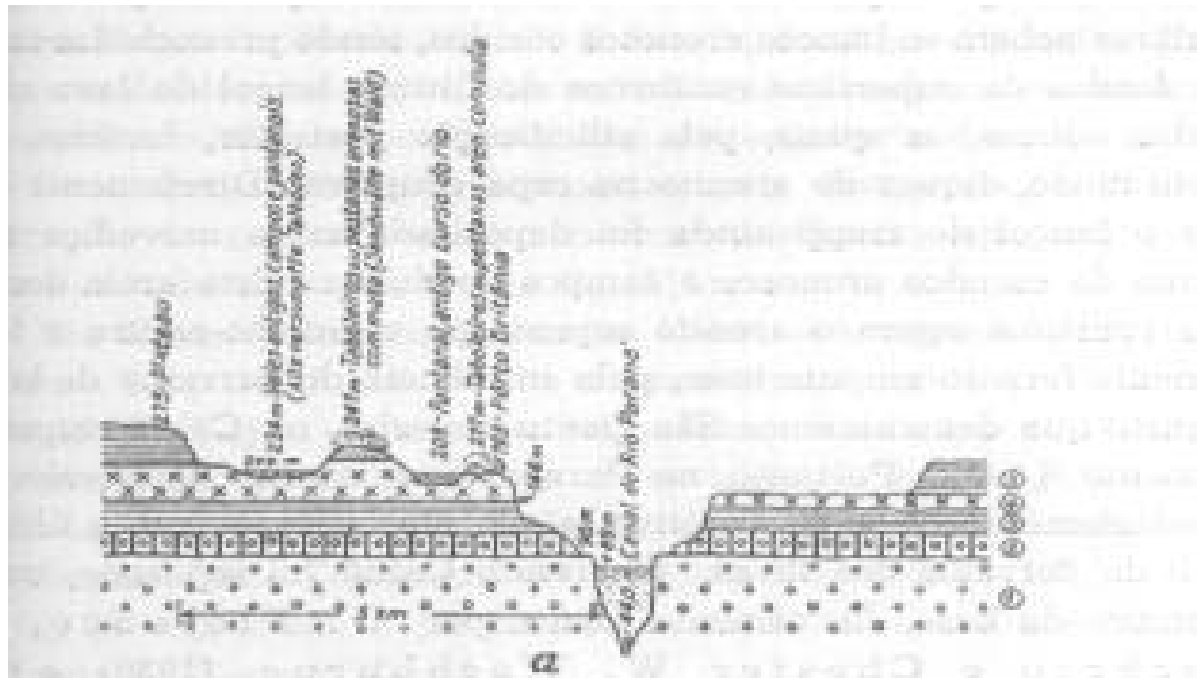

Perfil esquemsitico atravis do cañan do Rio Parand, en Fïrto Bontsinia

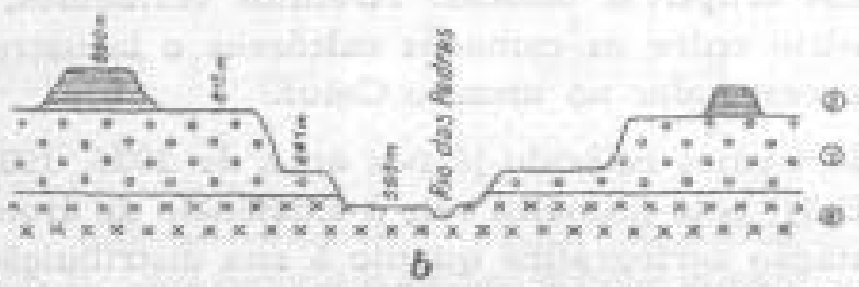

Perfil esquematico através das lencoies de eruptivas busices no vale do Rio das Pedras

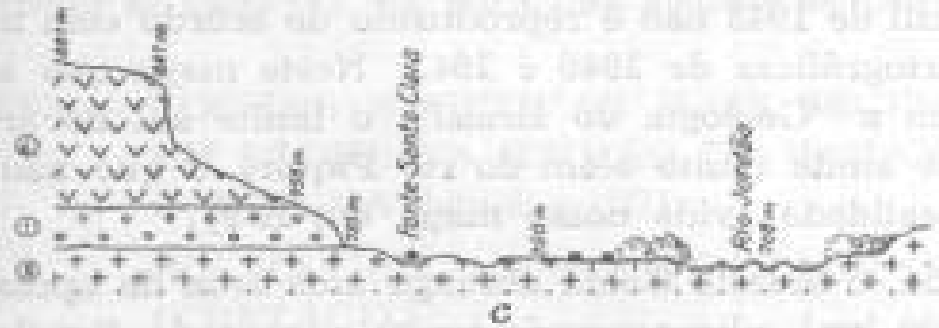

Corte através dos lenfóes de eruptivas básicas nas margens do Rio Jordāo, em Santa Clara

Fig- 12

0- Mesifinas com drusas finzor de calota, heulandita, elC.

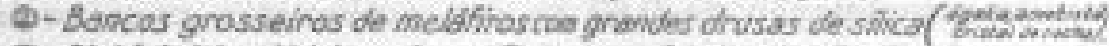

(1)- Diaddsio miterstoid, en chupas finas, can fendas de sinica

(9) - Lava en grandes blocos estenoridais (Oiabástio).

(5)-Disbulsio intersticial de granulo cấo fins.

a- arabisia parfiritico (basaltito)

Fig. 12 - Corte através dos lençóis de eruptivas básicas nas margens do Rio Jordão, em Santa Clara. Paraná. 


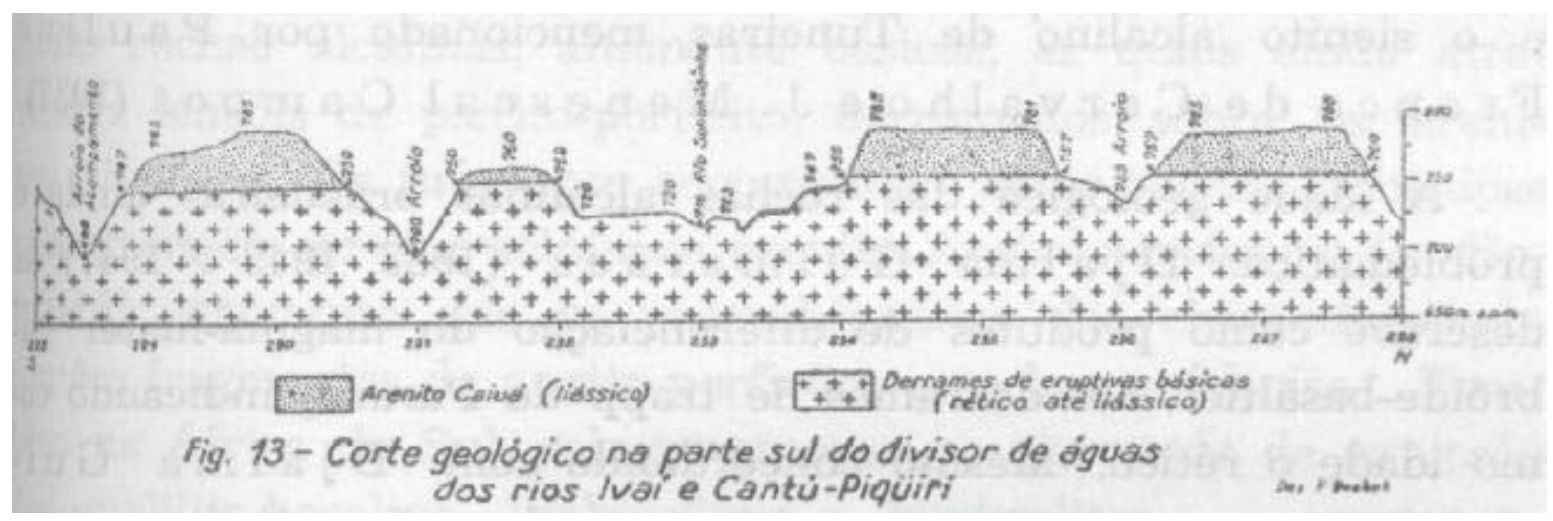

Fig. 13 - Chapas do arenito Caiuá sobre rochas eruptivas nas mesetas do divisor de águas dos rios Ivaí - Cantú a sueste de Campo Mourão. Paraná.

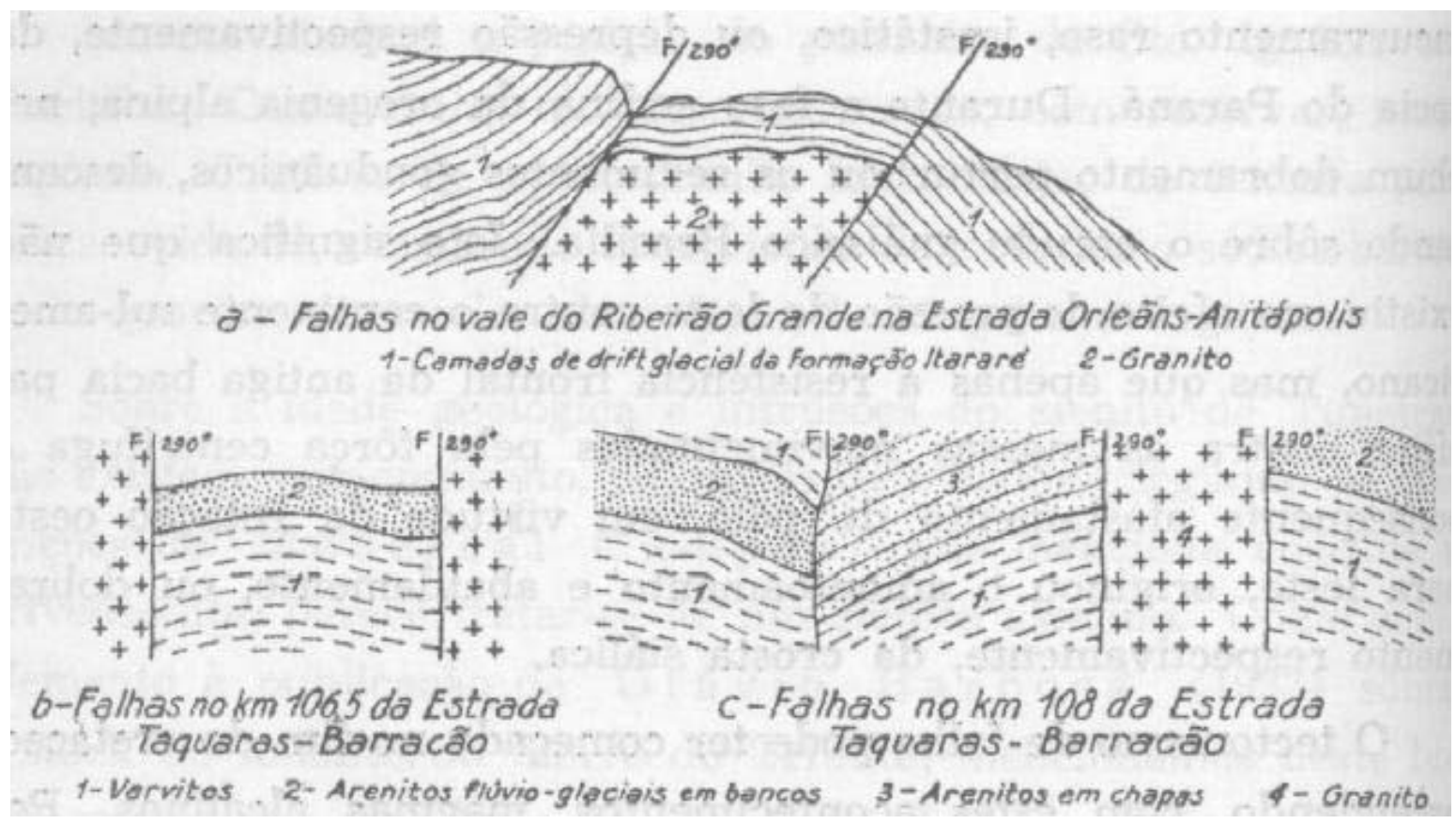

Fig. 14 - Esboços de falhas nos vales do rio Tubarão - Braço Norte (Ribeirão

Grande) e rio Itajaí - Braço Sul, no Estado de Santa Catarina. Paraná. 


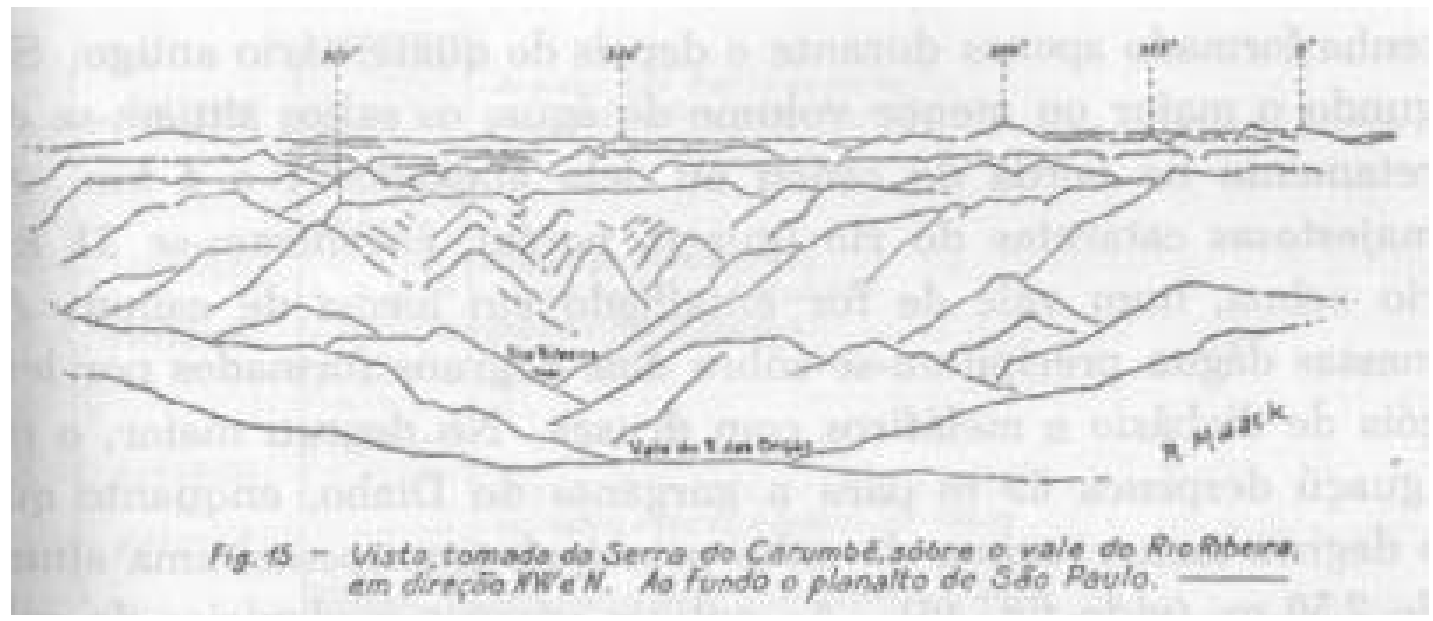

Fig. 15 - Vista do ribeirão do Rocha sobre o vale do rio Ribeira, mostrando o plano de denudação recente do planalto de São Paulo. Paraná. 


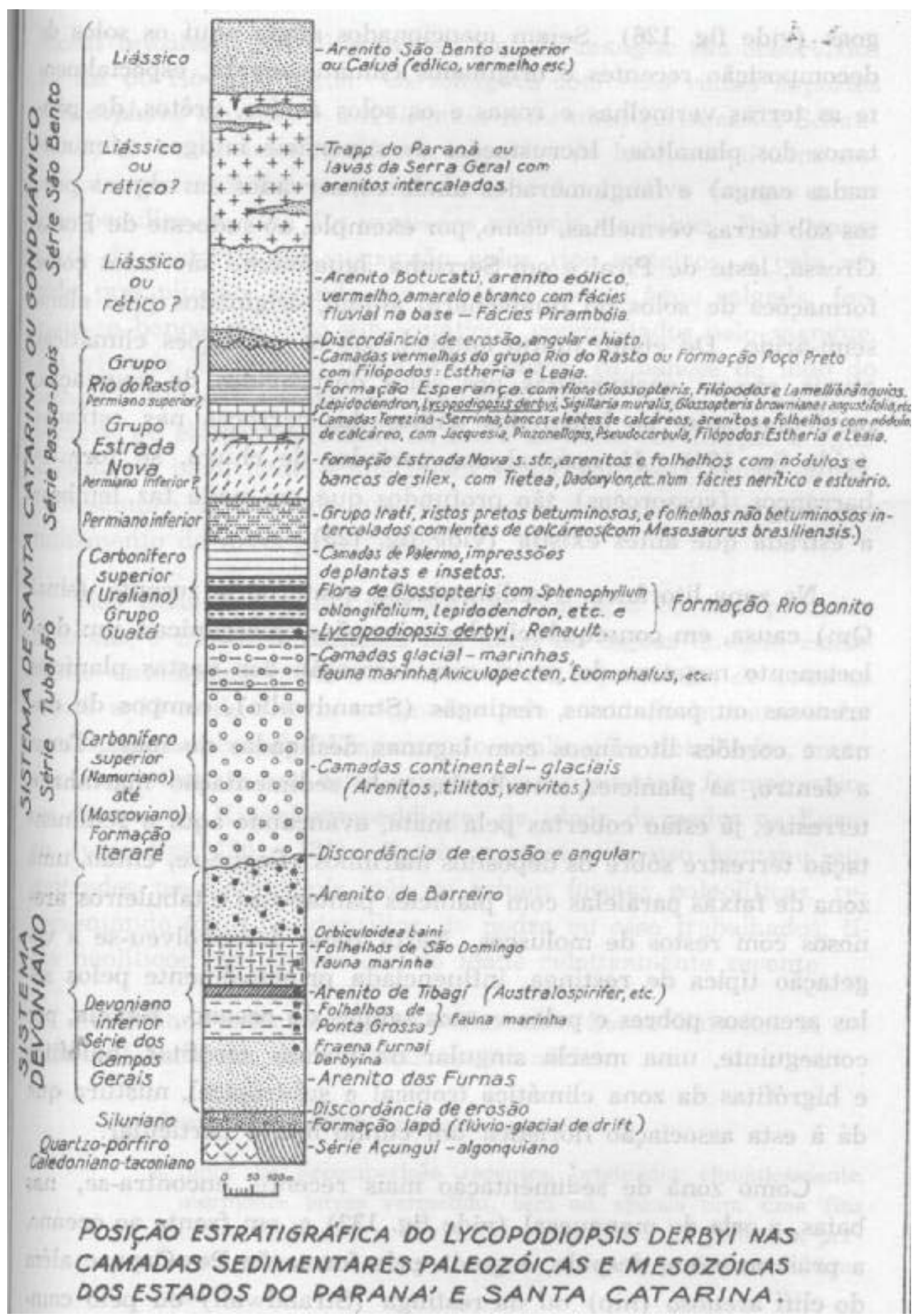

Fig. 16 - Esquema ilustrativo da nova classificação estratigráfica dos sistemas devoniano e Santa Catarina com as espessuras médias das diversas formações. Paraná. 


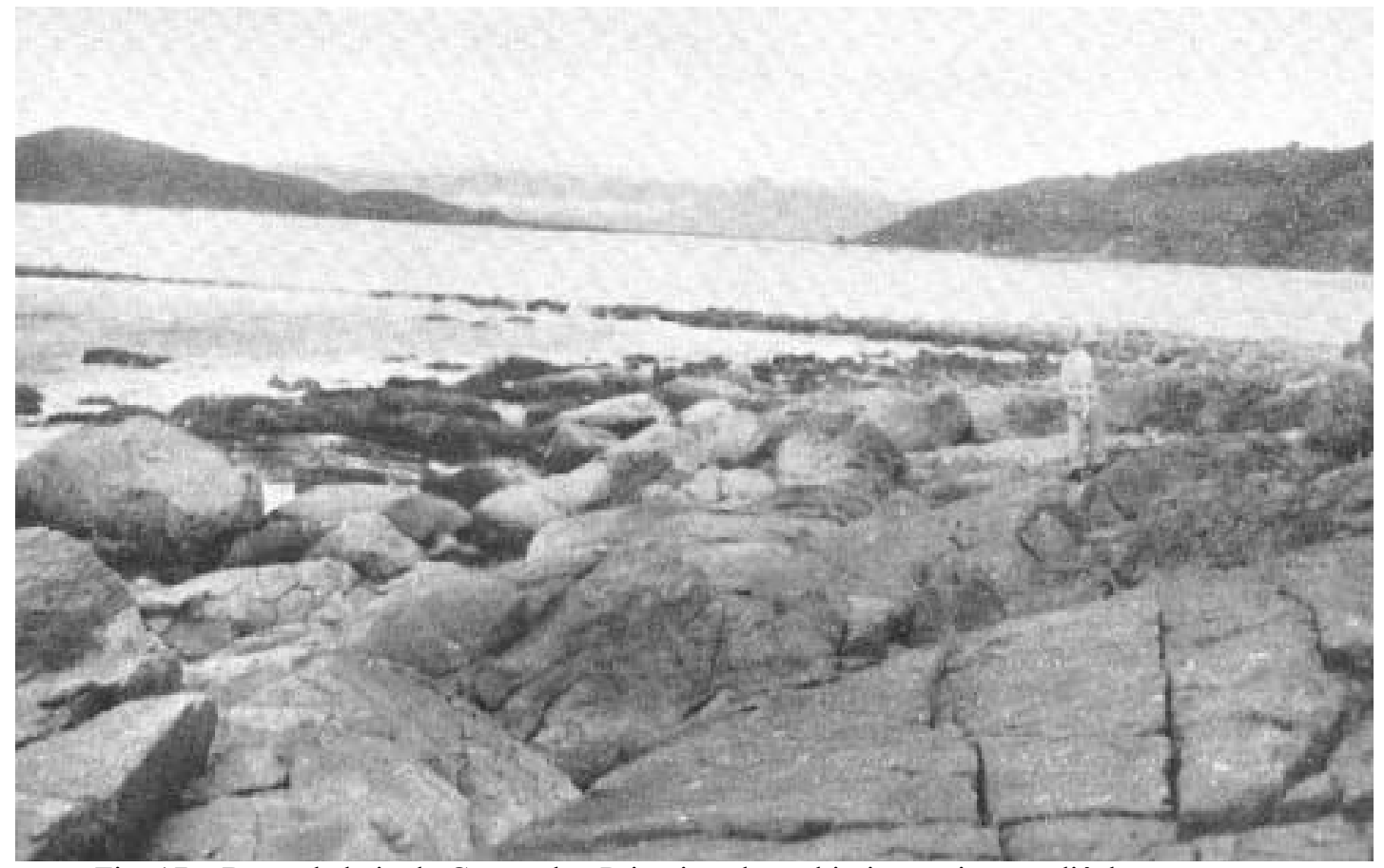

Fig. 17 - Barra da baia de Guaratuba. Primeiro plano: biotita-gnais com diáclases na direção das linhas de estrutura de $\mathrm{S} 50^{\circ} \mathrm{W}\left(\mathrm{N} 70^{\circ} \mathrm{E}\right)$; segundo plano: dique de diabásio rumo $\mathrm{N} 45^{\circ} \mathrm{W}$; ao fundo: as serras de Araçatuba e Iqueririm. Paraná.

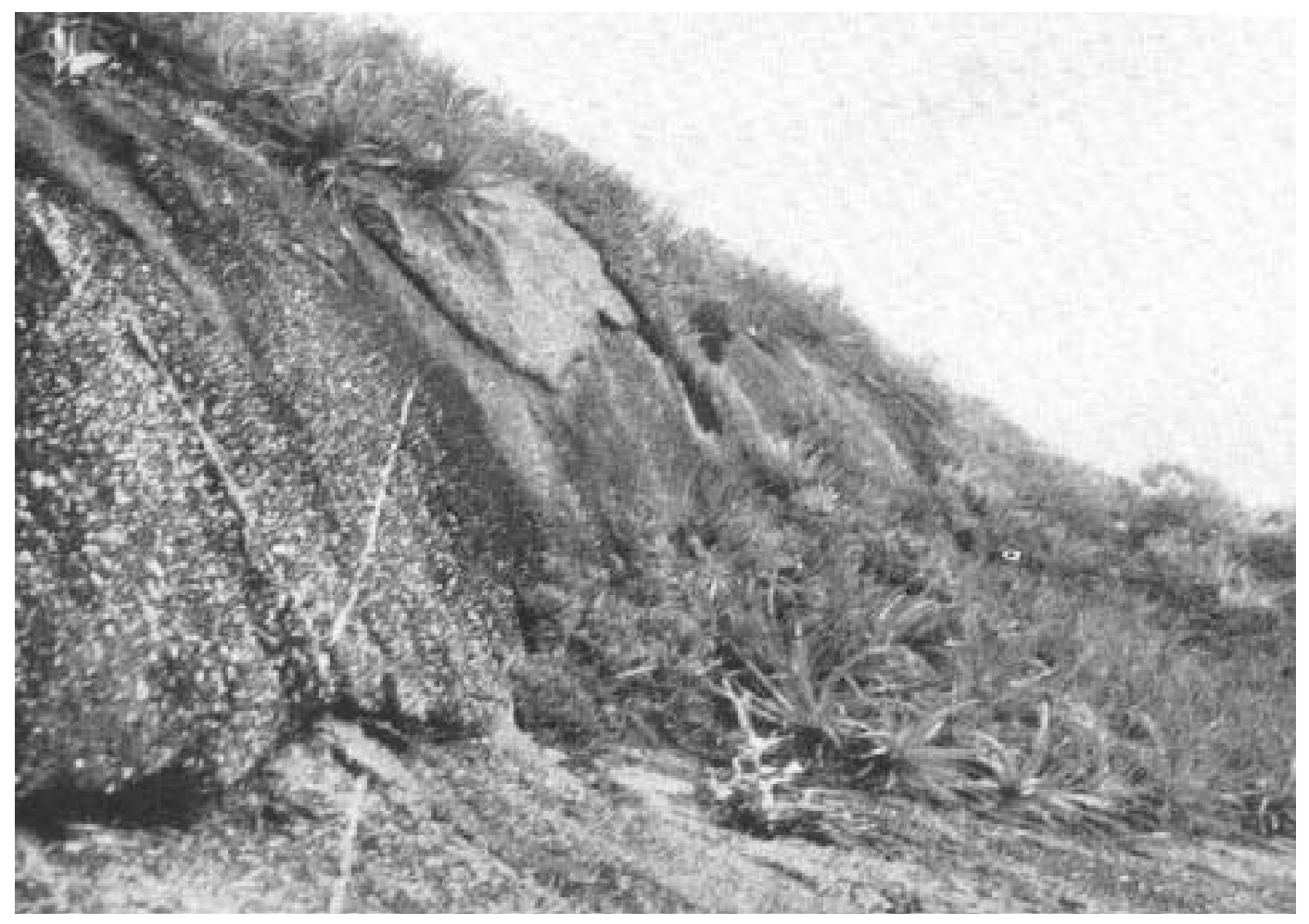

Fig. 18 - Antigo cliff em gnais-granito-pórfiro, coberto pela vegetação, a 7,50 m acima da marca da preamar. Paraná. 


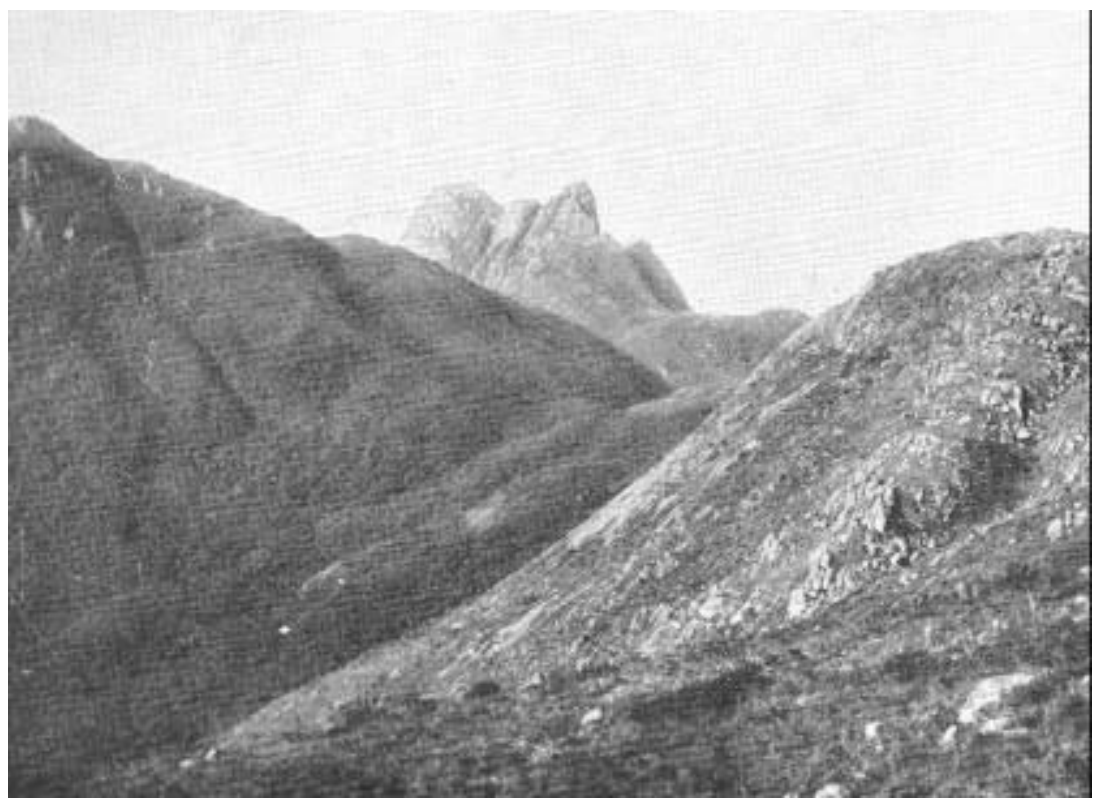

Fig. 19 - O Pico Paraná (1965,6 m), visto do alto Camapuã (1785 m). Direção do Pico Paraná $=$ N95 E azim. magn. Paraná.

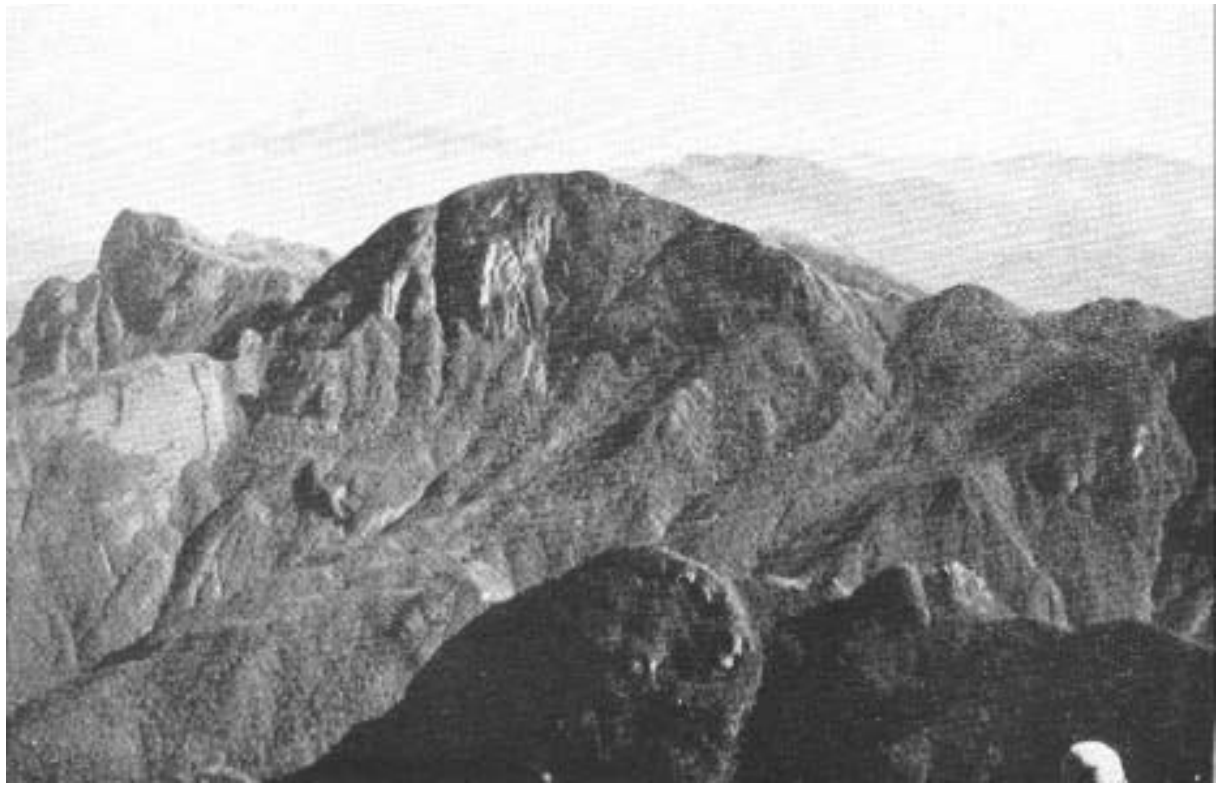

Fig. 20 - Vista tomada do Pico Paraná sobre a agulha da Cotia $(1521 \mathrm{~m})$ e o paredão do Pico Ciririca (1781 m) com escadas de falha. Ao fundo, vê-se a Serra Graciosa com restos de peneplano inclinados suavemente para W. Paraná. 


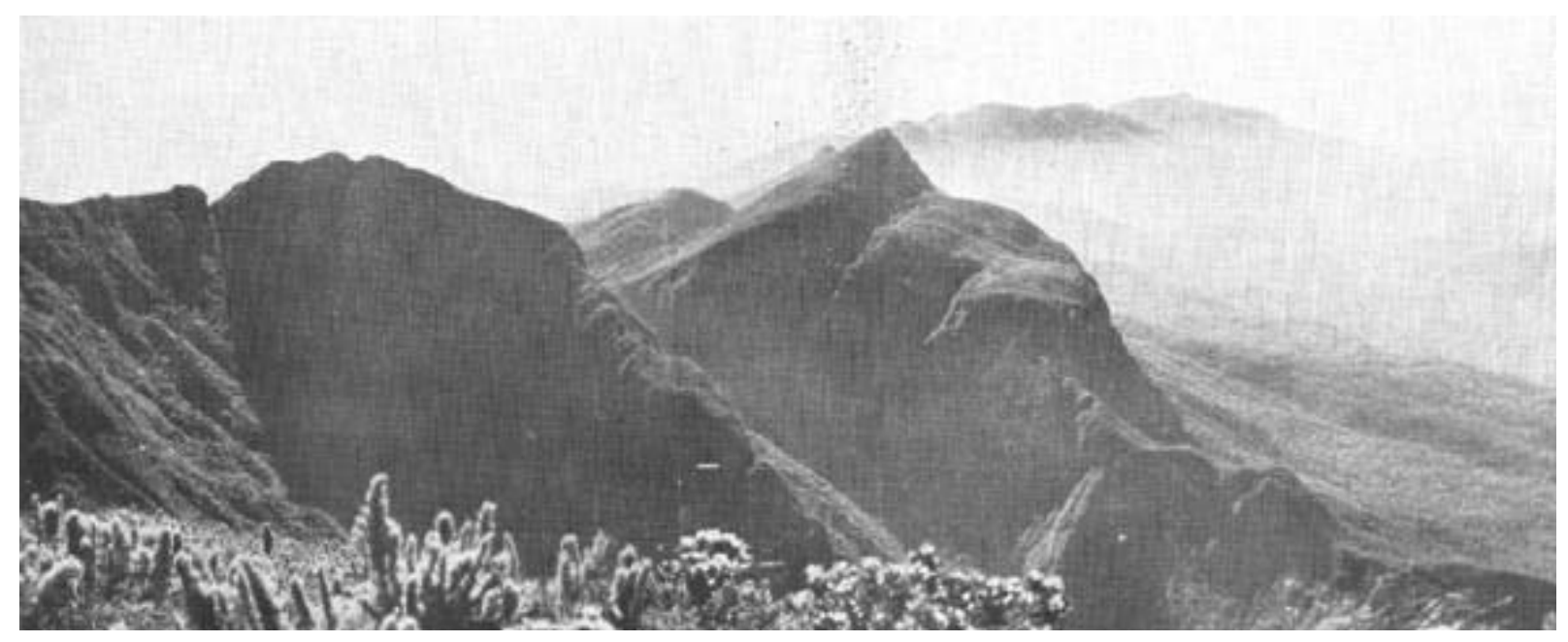

Fig. 21 - Um bloco em posição oblíqua em virtude de falha, Pico Ferraria na Serra do Mar (1835 m). Ao fundo a Serra Capivari Grande (1694 a 1716 m). Vista do Pico Paraná para N e NE. Paraná.

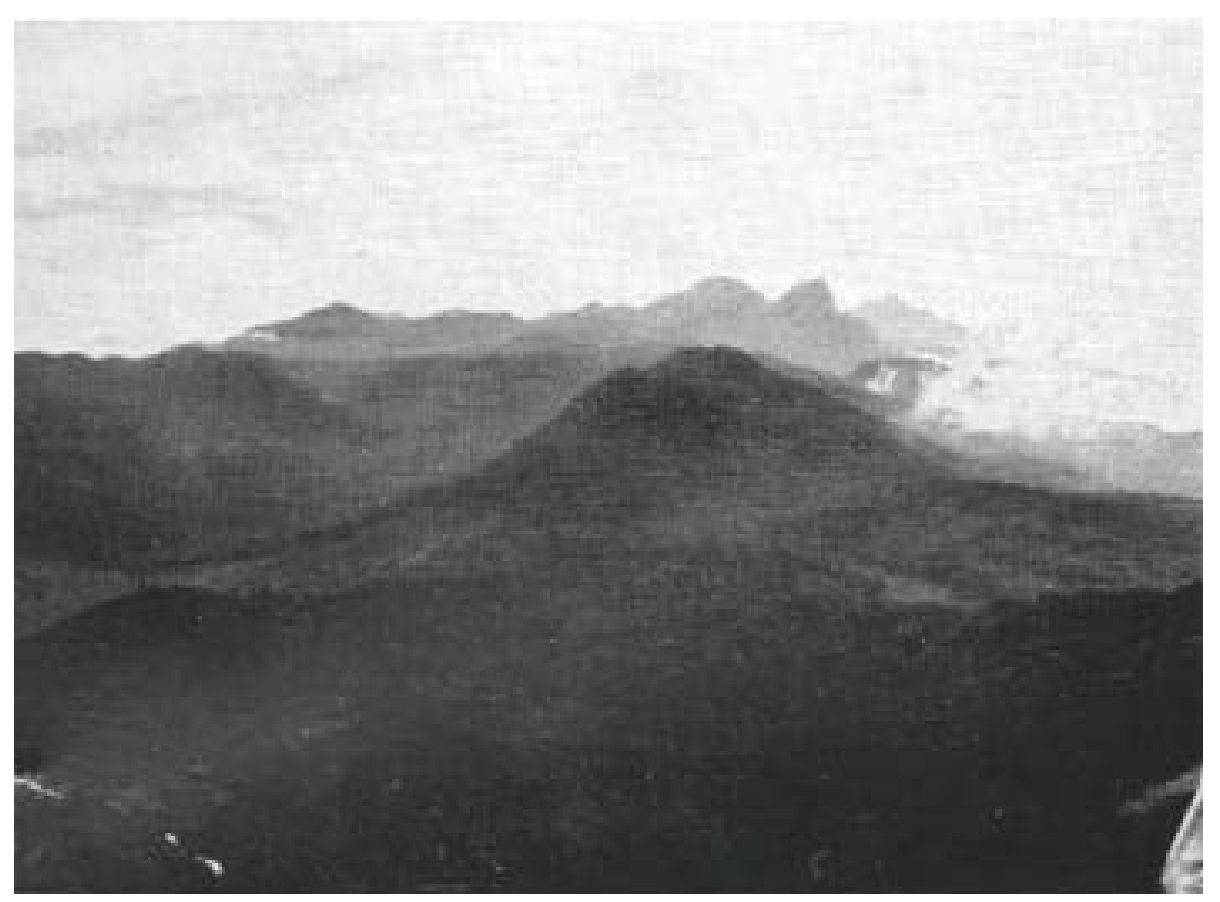

Fig. 22 - Antigos níveis de denudação na Serra Ibiteraquire com a agulha da Cotia e o Pico Paraná, vistos do morro do Bicho, em São João, na direção $\mathrm{N} 23^{\circ} \mathrm{E}$ azim. magn. Paraná. 


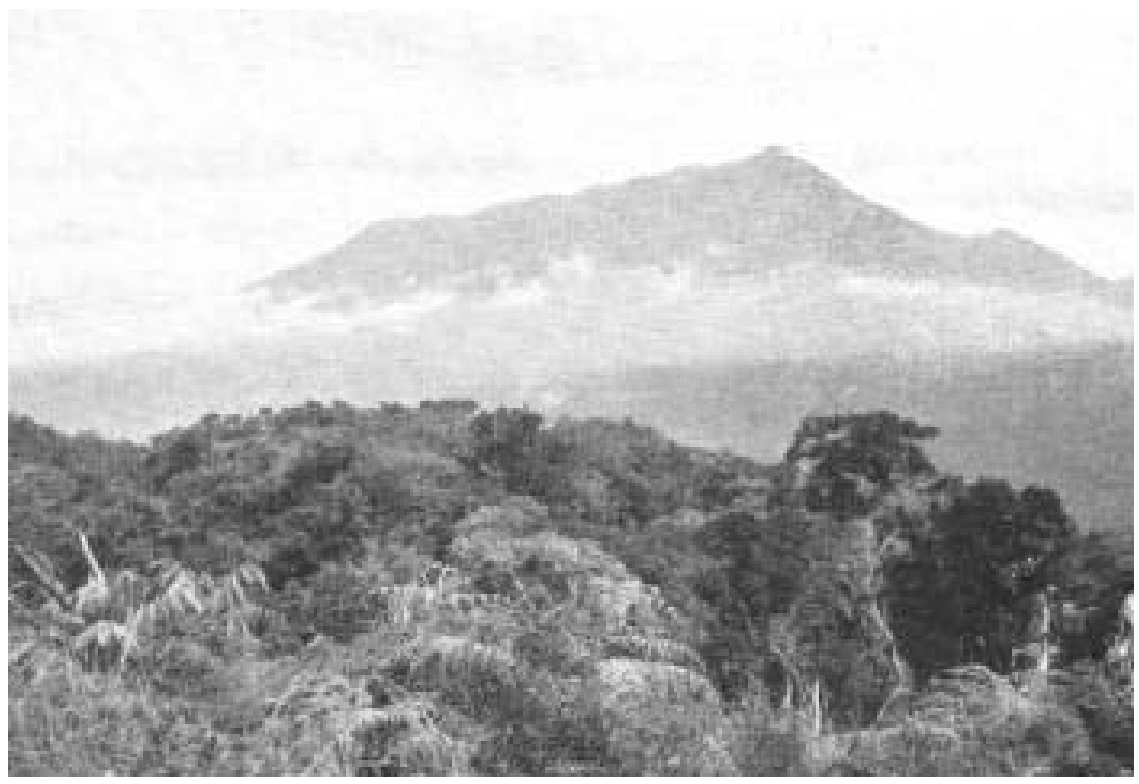

Fig. 23 - O Pico Marumbi (1547 m), tomado do morro do Bicho em direção S57 $\mathrm{W}$ azim. magn. Paraná.

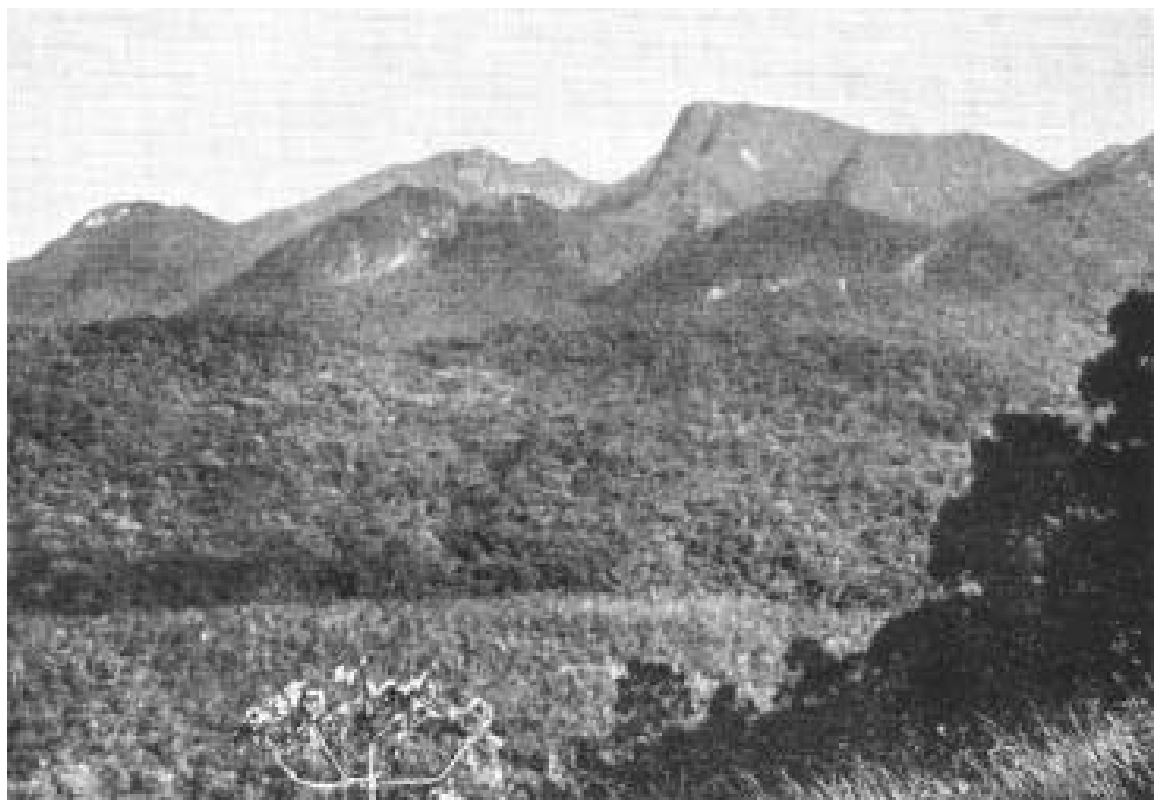

Fig. 24 - Escadas de falha diante da escarpa da Serra Graciosa, na Serra do Mar. Paraná. 


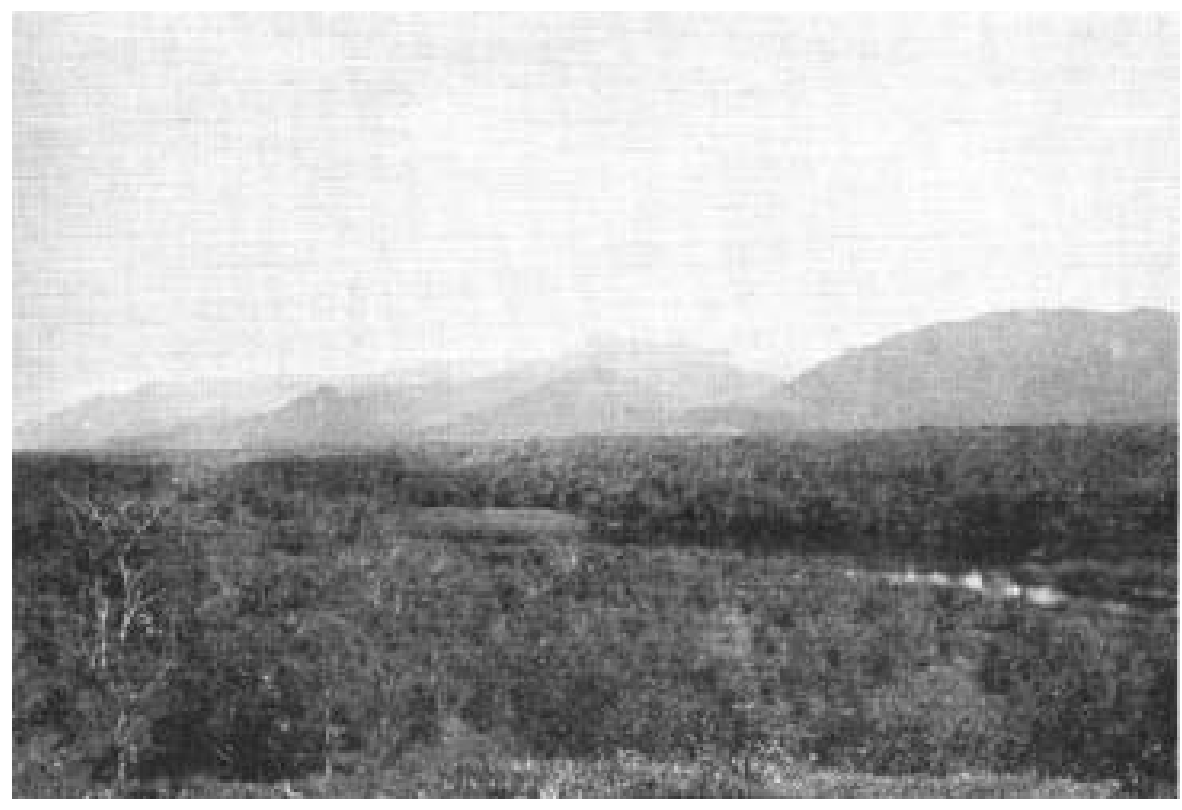

Fig. 25 - Vista tomada de Arariba em direção $\mathrm{S} 60^{\circ} \mathrm{W}$ magn., sobre a parte sul da Serra do Mar no Paraná. No centro destaca-se a Serra Araraquara com resto de peneplano (Rumpftafel) inclinado para W. Ao fundo as serras Iqueririm (1450 a 1510 m) e Araçatuba. Paraná.

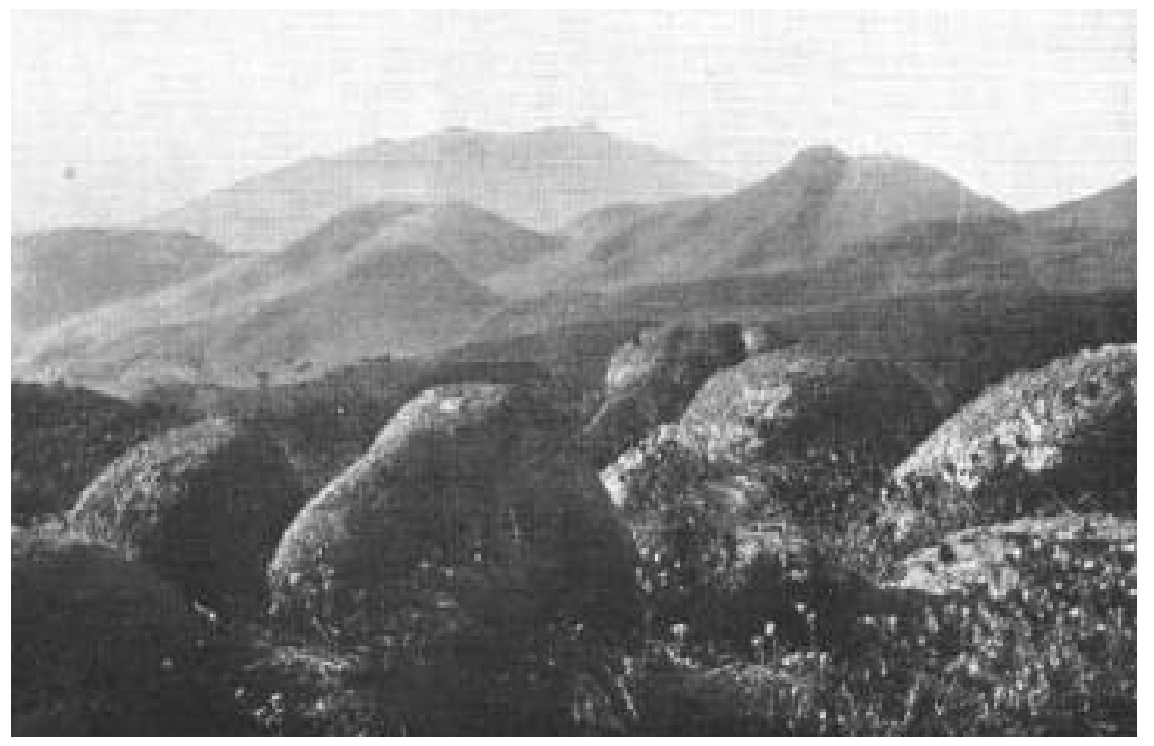

Fig. 26 - Vista tomada do alto Camapuá sobre o pico Guaricana $(1551 \mathrm{~m})$ e a Serra Capivari Grande em direção N10E. Paraná. 


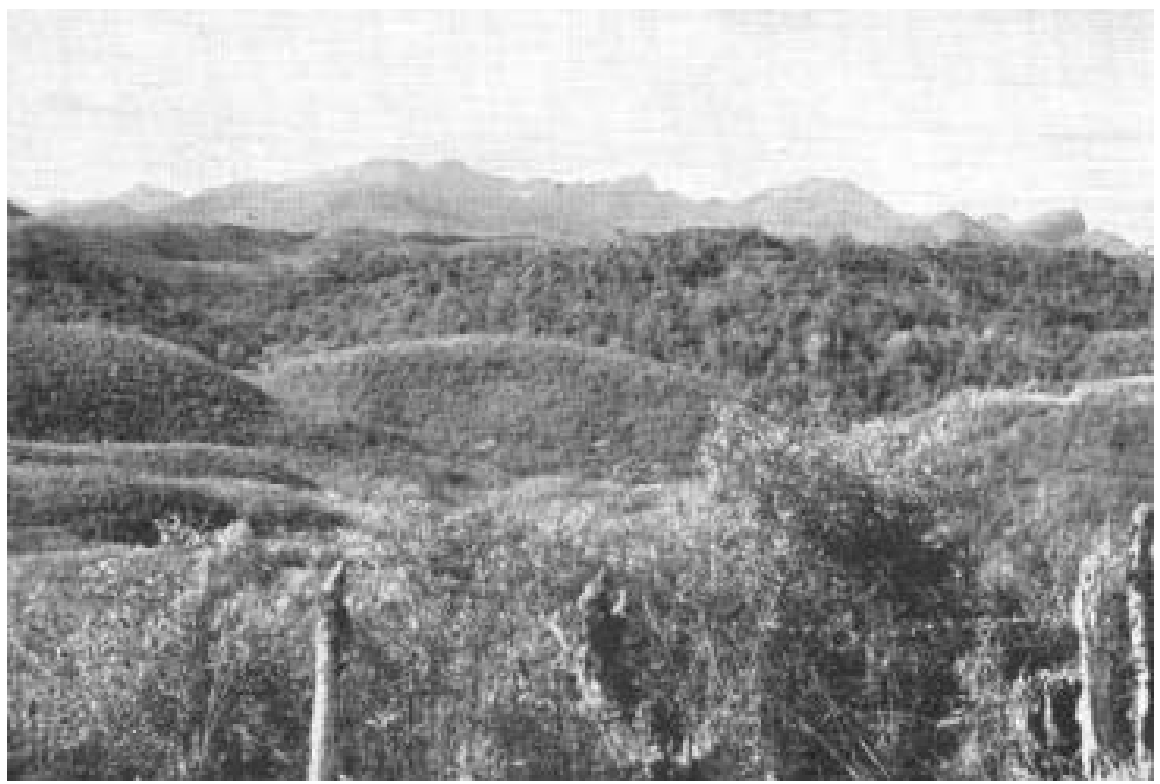

Fig. 27 - A serra marginal da Serra do Mar. No primeiro plano o terreno ondulado do planalto; ao fundo a Serra Ibiteraquire (Serra dos Órgãos). Paraná.

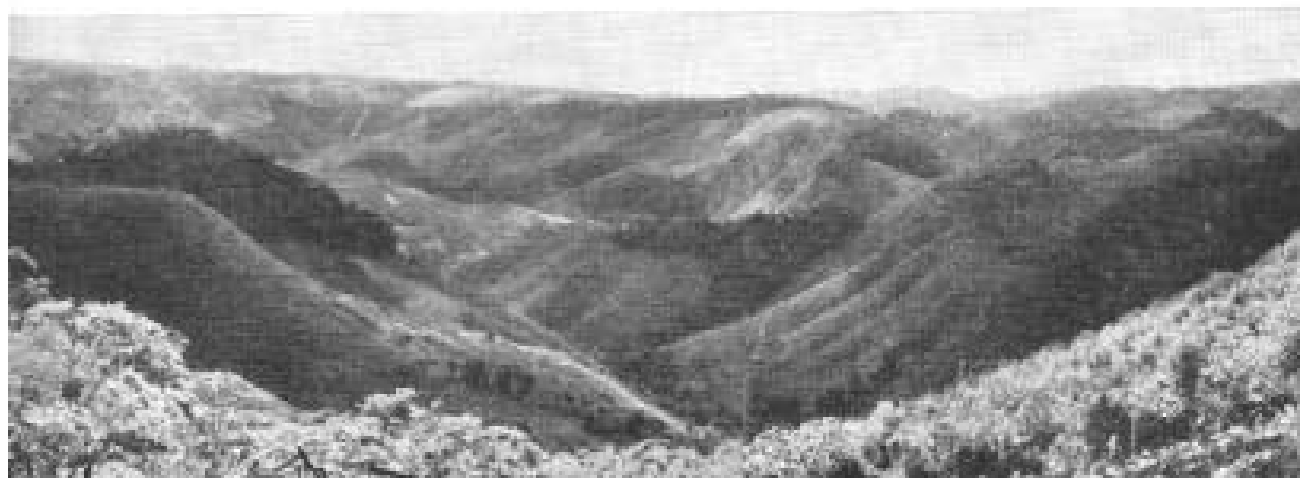

Fig. 28 - A zona montanhosa do vale de rio Ribeira. O plano de denudação recente, semelhante a um peneplano, passa uniformemente sobre todas as elevações. Vista ao longo do vale do rio Bom Sucesso em direção N. Paraná. 


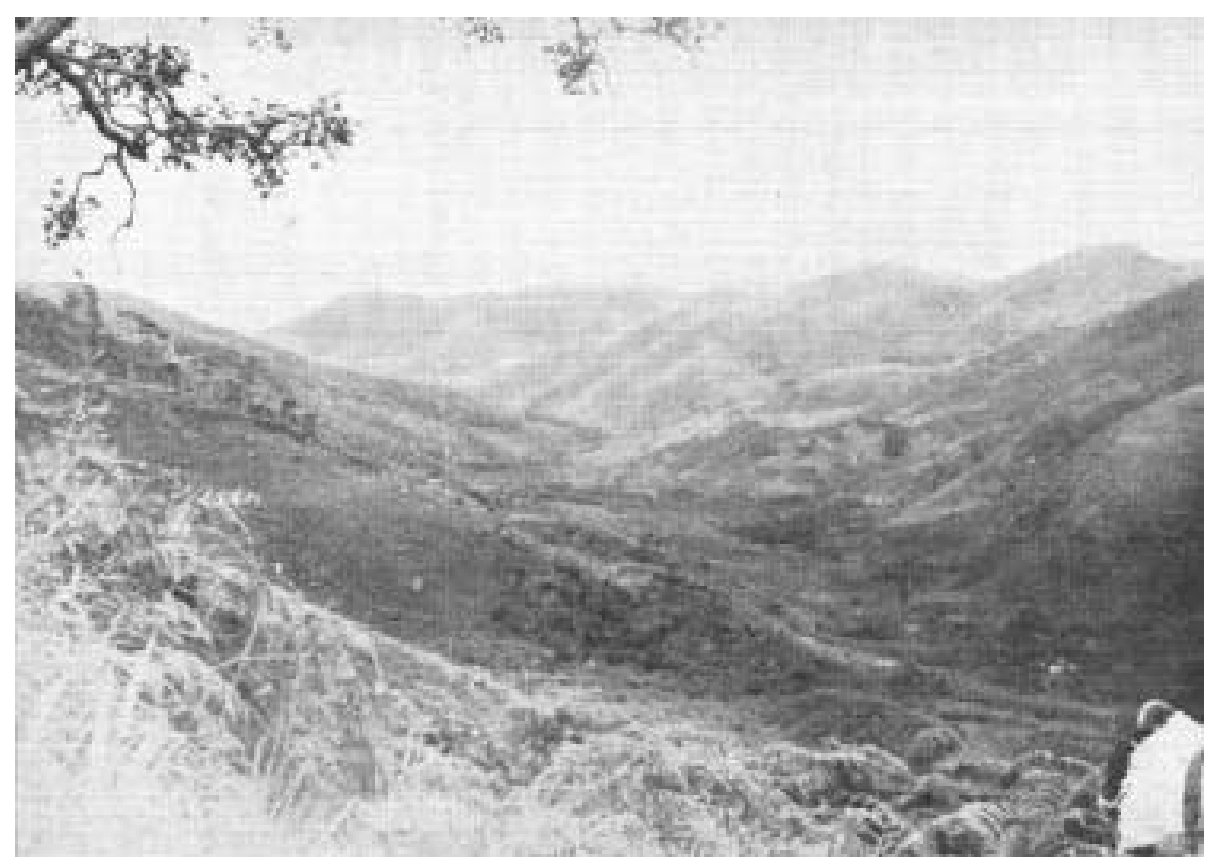

Fig. 29 - Vale do rio Carumbê entalhado nas rochas da série Açunguí (vide fig. 7). Os flancos do vale são constituídos de filitos. A direita: elevações calcáreas. Paraná.

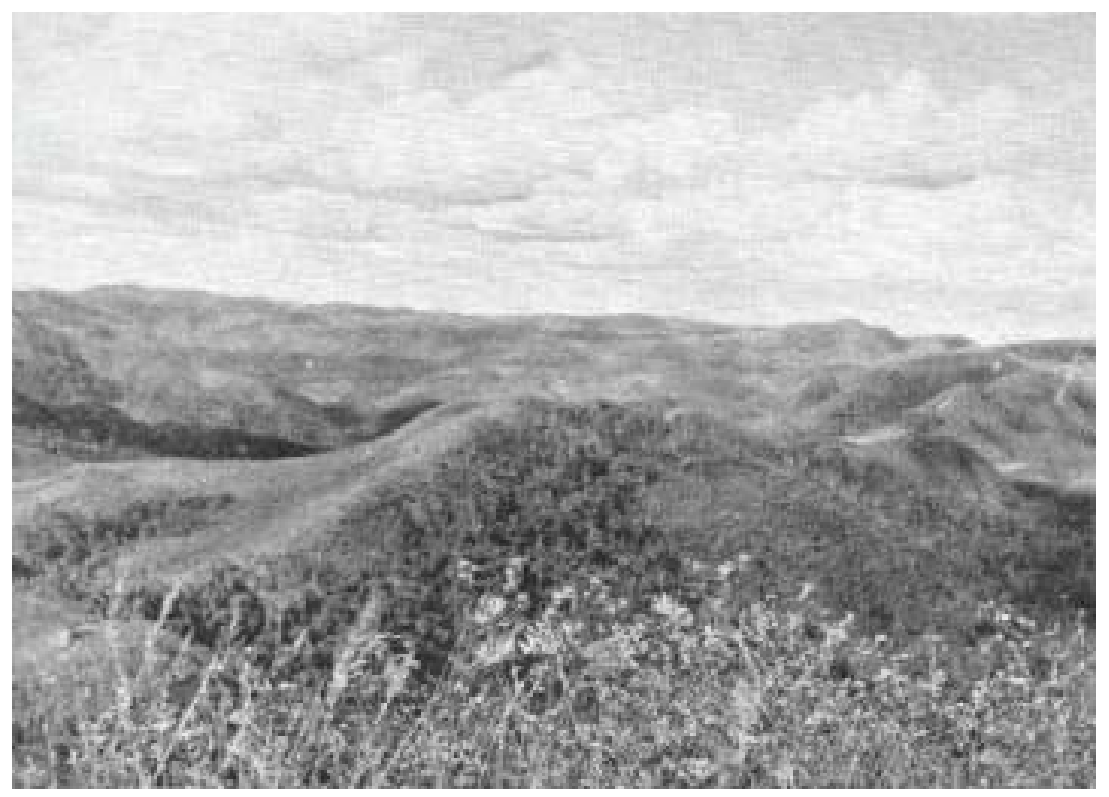

Fig. 30 - Primeiro planalto. Paisagem montanhosa típica da série Açunguí; vista tomada da Serra Ouro Fino em direção NW. Paraná. 


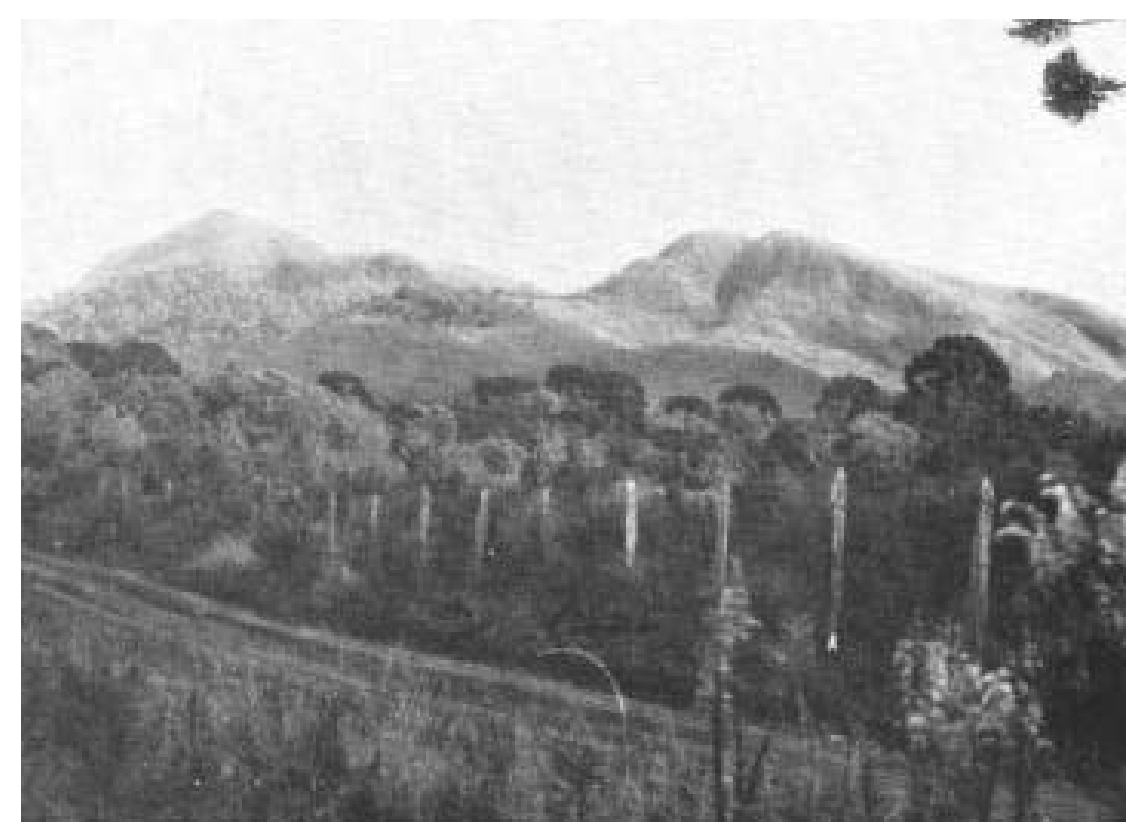

Fig. 31 - Primeiro planalto. Cabeços de estratos (hogbacks) de quartzito entre filitos da série Açunguí em Itaperuçú, município de Rio Branco do Sul (exVotuverava). Paraná.

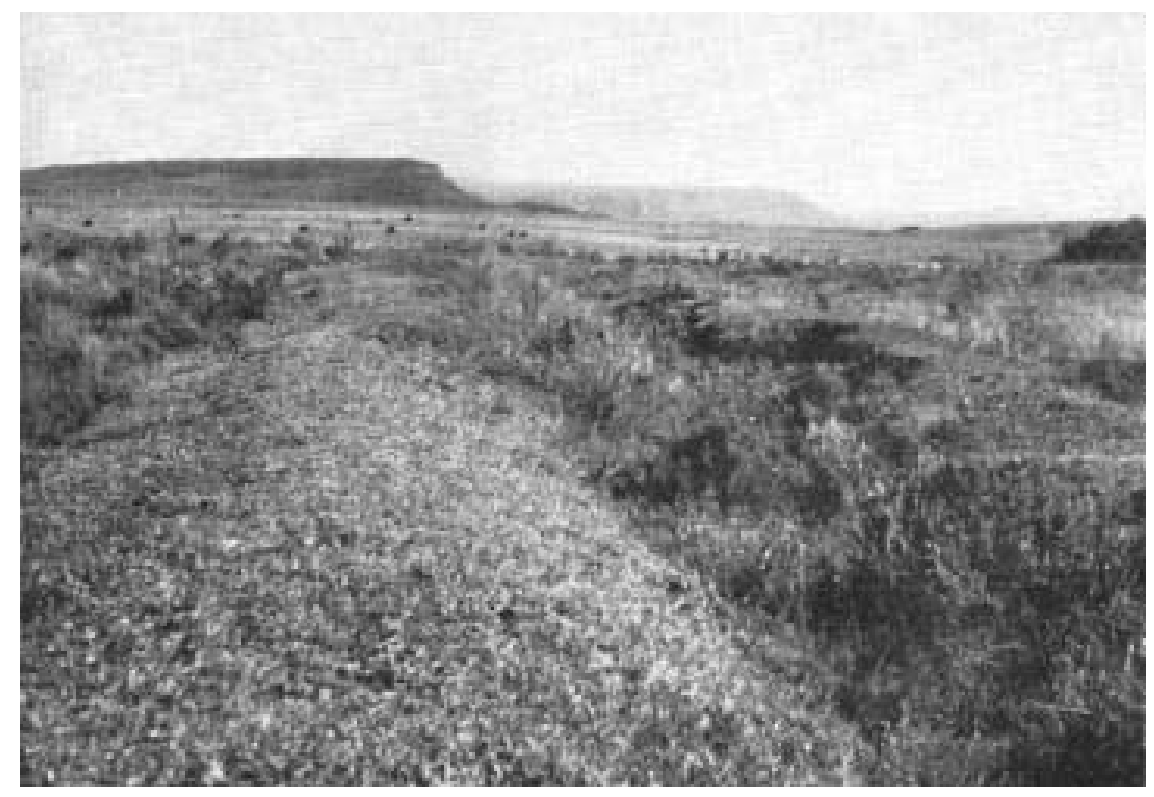

Fig. 32 - Segundo planalto. A escarpa devoniana em São Luiz do Purunã; vista tomada do km 50 em direção NW. Paraná. 


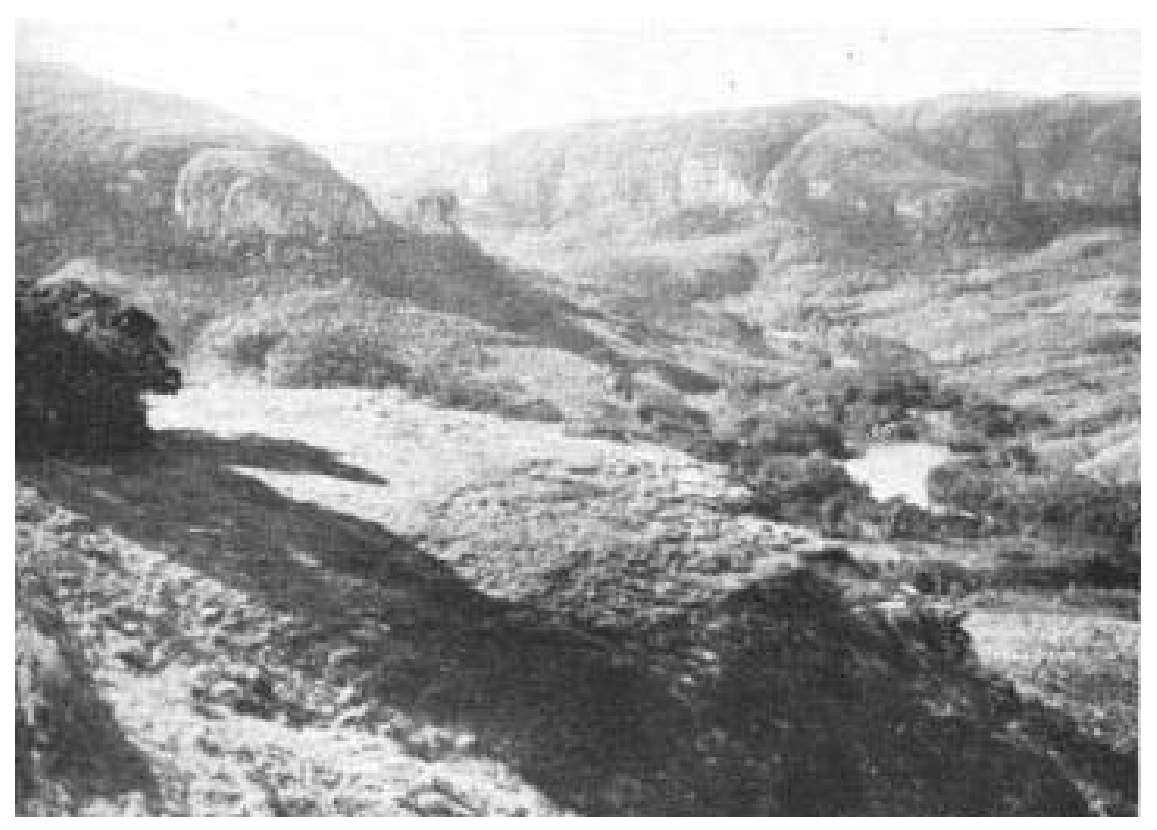

Fig. 33 - Segundo planalto. O vale do rio Iapó com paredões de arenito das Furnas sobre quartzo-pórfiros e xistos da série Açunguí. Vista tomada em direção NW. Paraná.

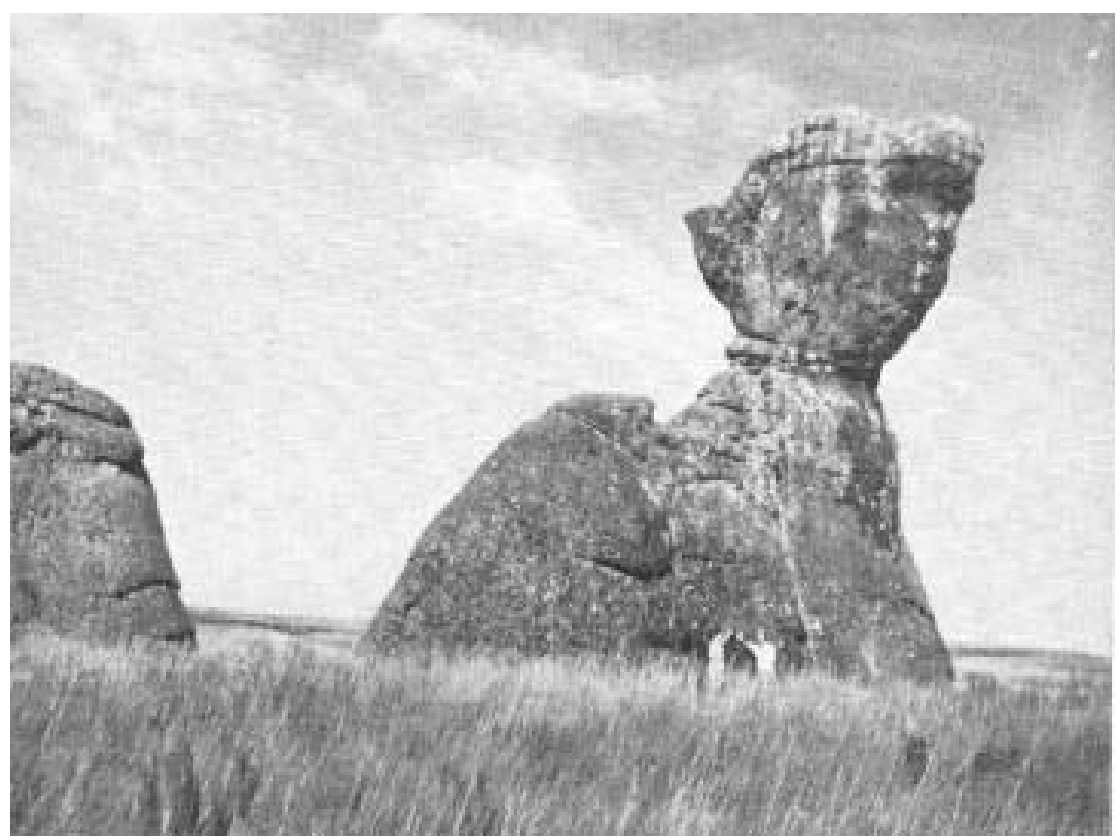

Fig. 34 - Segundo planalto. A Esfinge, forma de desagregação do arenito flúvioglacial vermelho de Vila Velha. Paraná. 


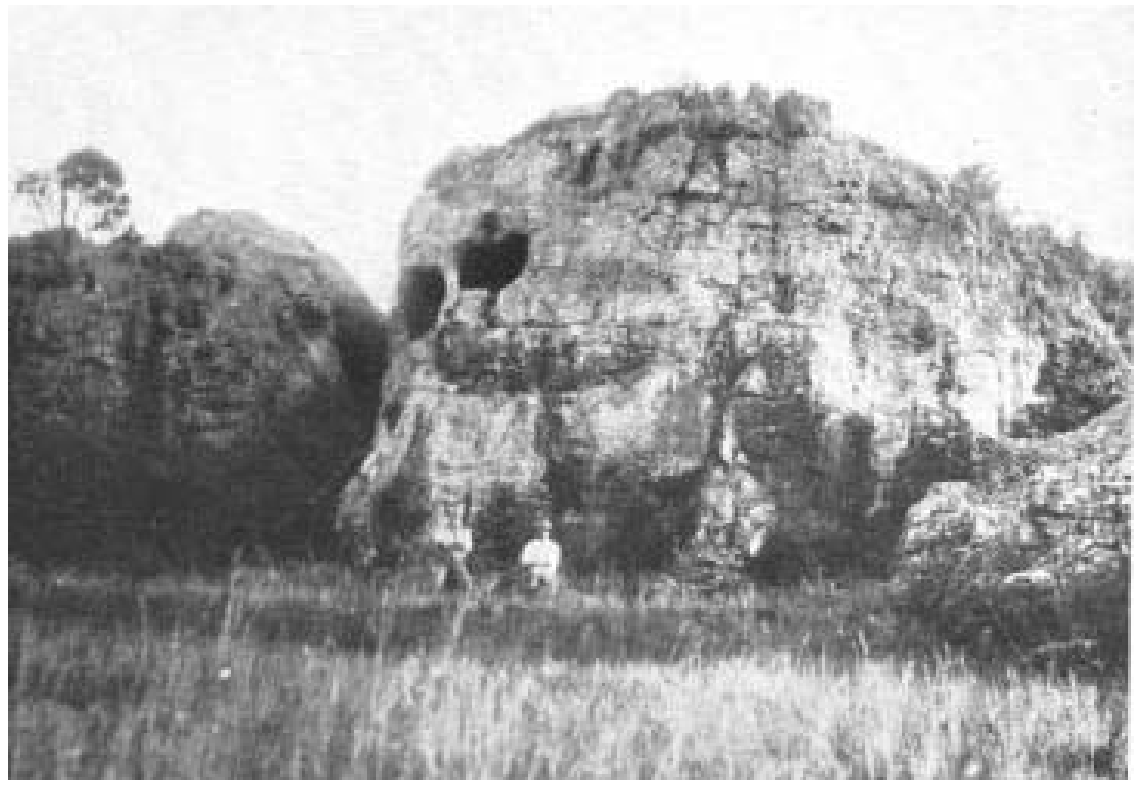

Fig. 35 - Segundo planalto. Rochas do arenito flúvio-glacial do grupo Itararé com cavidades pela desagregação. Localidade: Fazenda Monte Alegre, município de Tibagí. Paraná.

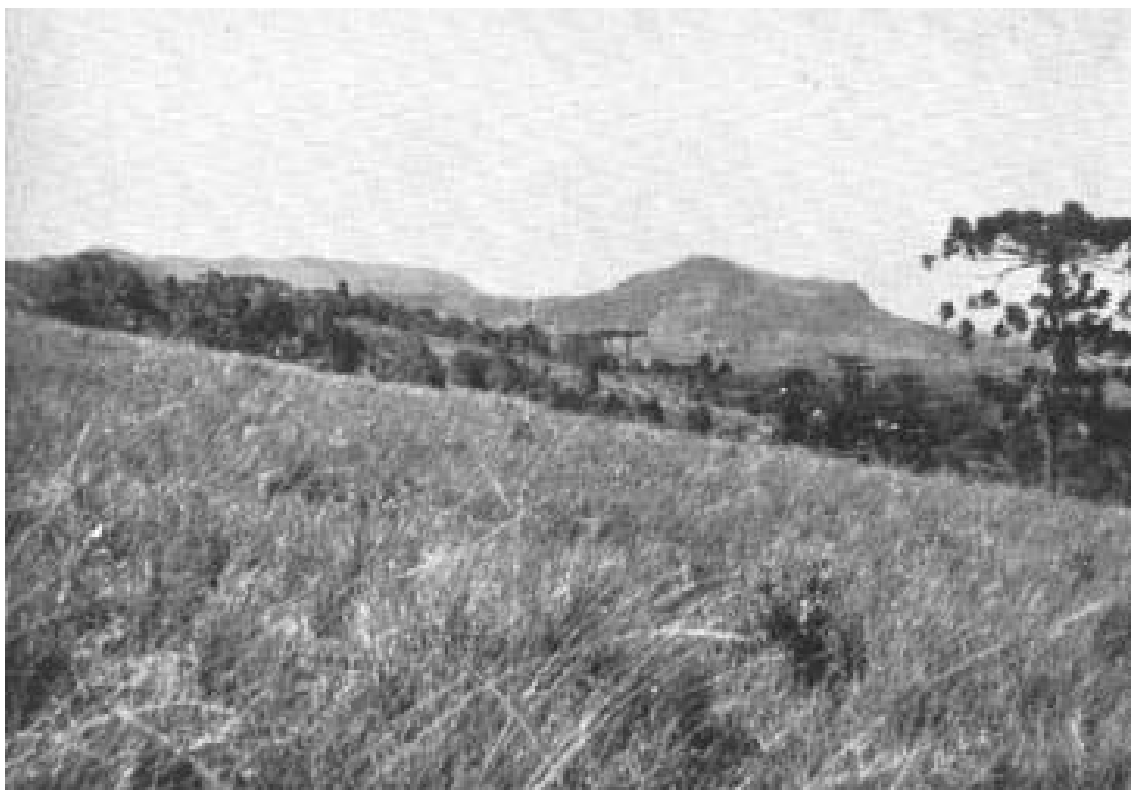

Fig. 36 - Segundo planalto. Mesetas de camadas glaciais do grupo Itararé nos Campos Gerais em Amparo. Paraná. 


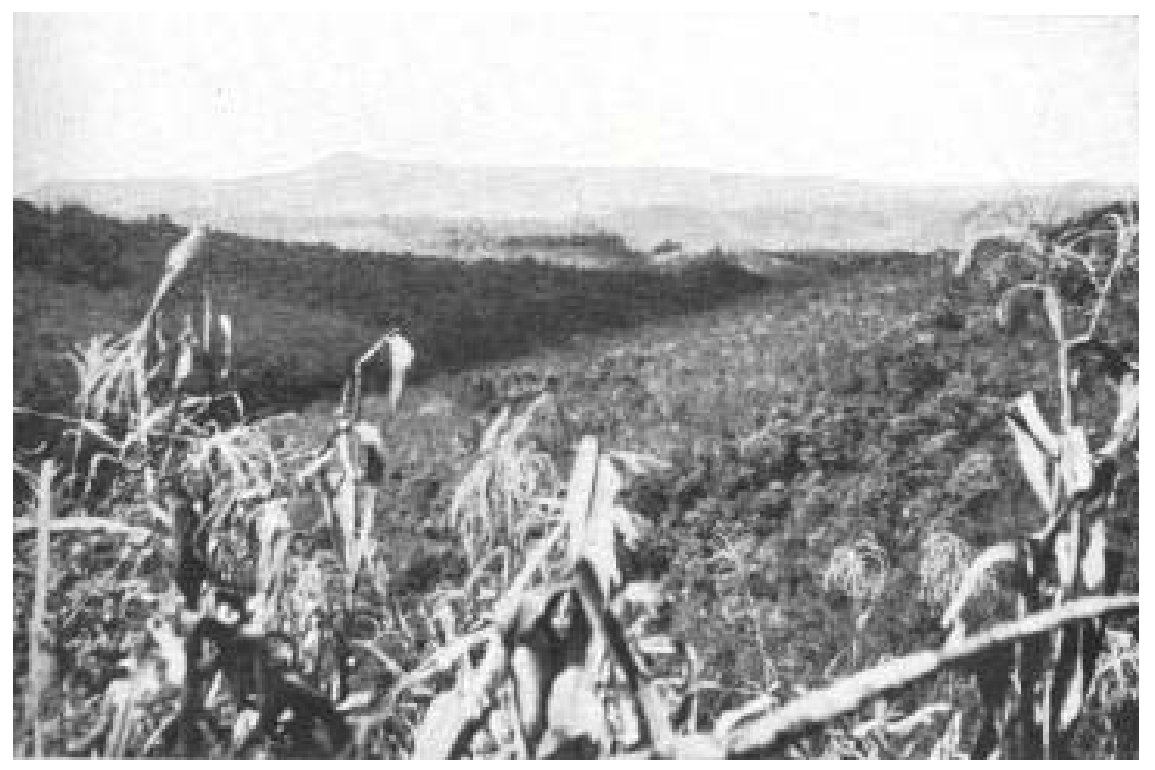

Fig. 37 - Segundo planalto. Mesetas de camadas gonduânicas (série Passa Dois), levemente inclinadas, na região do vale do rio Ivaí, ao sul de Cândido de Abreu. Paraná.

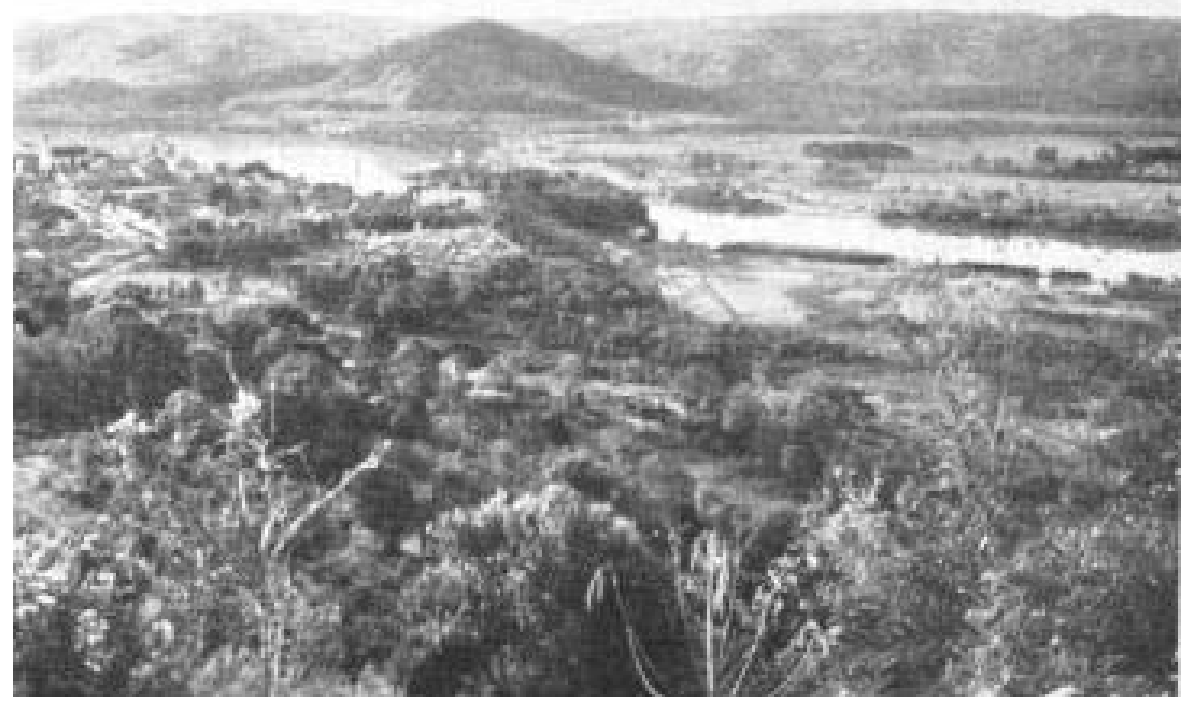

Fig. 38 - Segundo planalto. O rio Iguaçu em União da Vitória (735 m) antes de sua ingressão na escarpa triássico-jurássica da Serra da Boa Esperança. Paraná. 

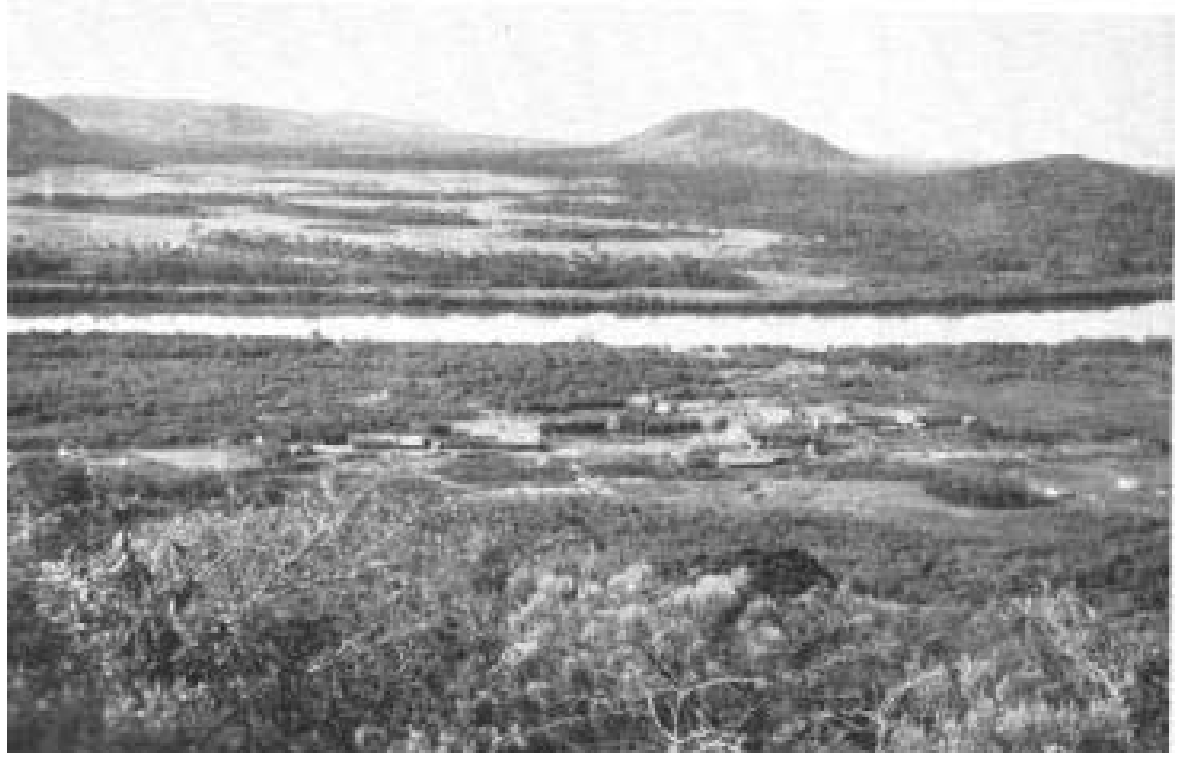

Fig. 39 - Segundo planalto. Morros de testemunho e antiga planície de aluvião (várzea) diante da escarpa triássico-jurássica na margem norte do rio Iguaçu, em União da Vitória. Paraná.

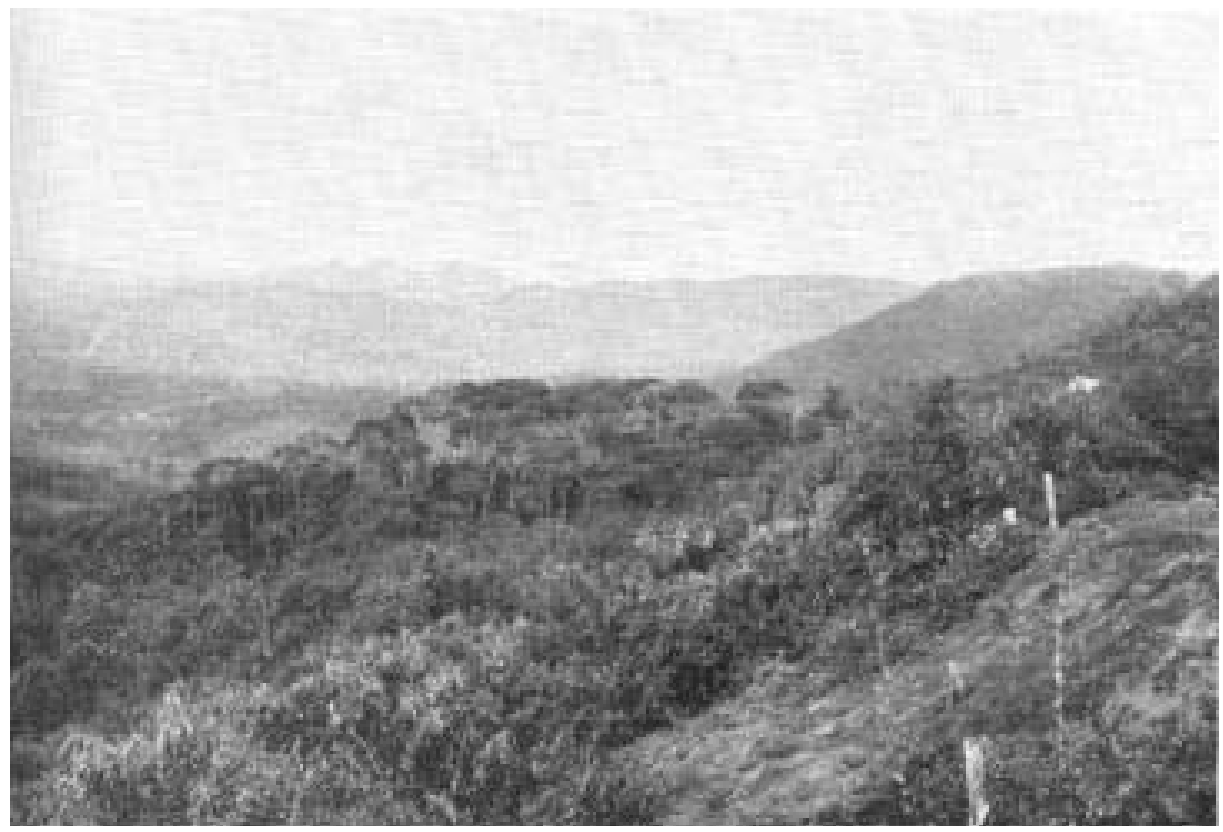

Fig. 40 - Terceiro planalto. A Serra da Boa Esperança, degrau estrutural triássicojurássico do perfil entre Prudentópolis (756 m) e Guarapuava (1082 a $1122 \mathrm{~m})$. Cota da testa da escarpa $=1150 \mathrm{~m}$. Paraná. 


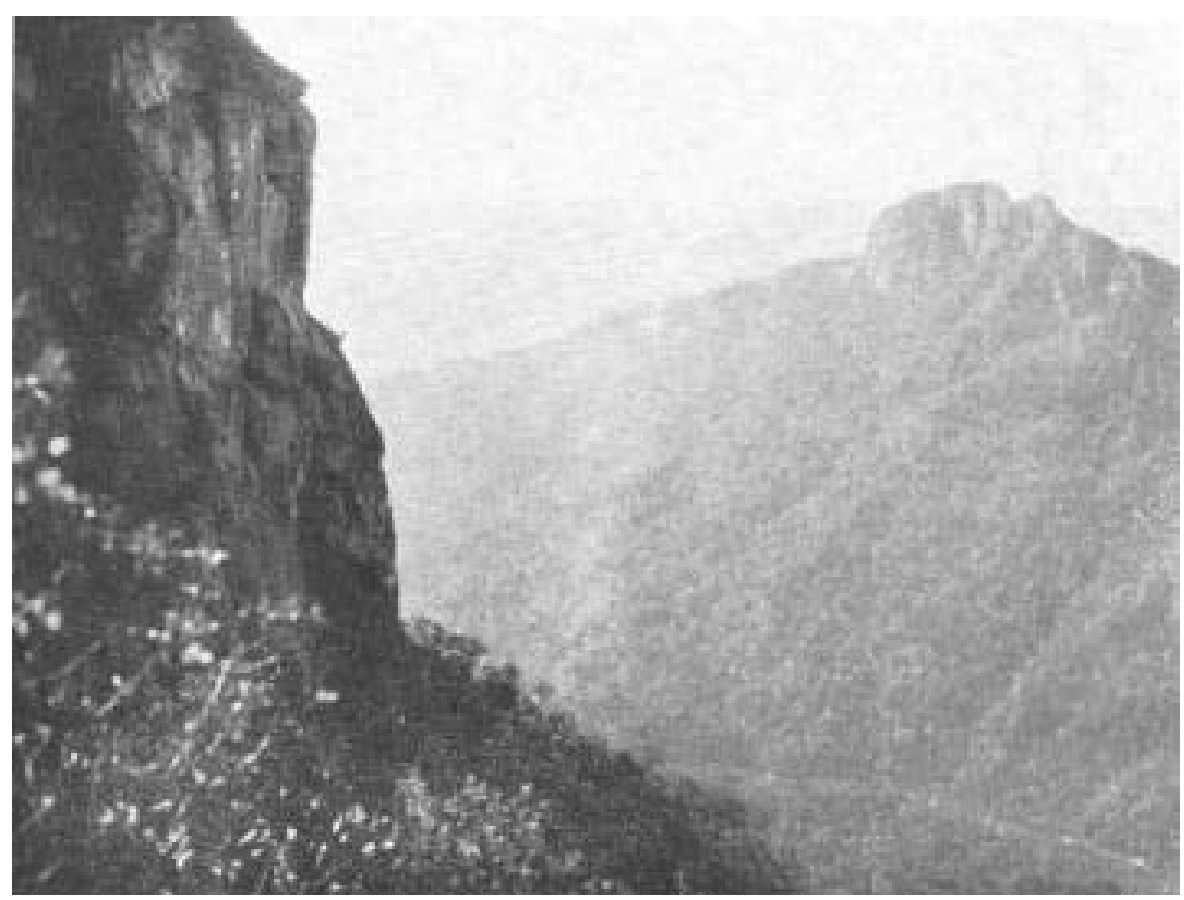

Fig. 41 - Terceiro planalto. Boqueirão do rio Tibagí na Serra dos Agudos (1210 m). As elevações à direita e à esquerda são constituídas por paredões de diabásio porfirítico, capeando as camadas gonduânicas. O vale antecedente do rio Tibagí é entalhado até 480 m s.n.m. Paraná.

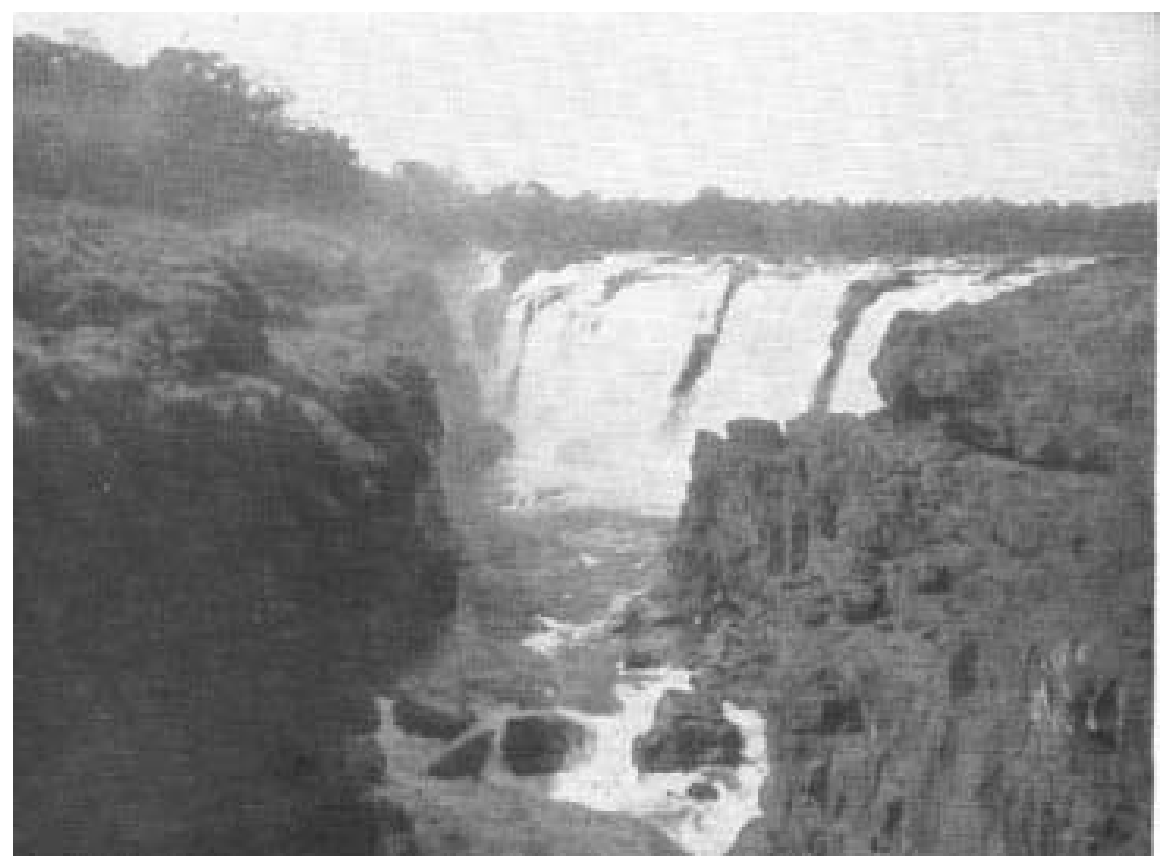

Fig. 42 - Terceiro planalto. A parte superior dos saltos das Sete Quedas, Guaíra, rio Paraná, entalhados em lençóis de diabásios e meláfiros, com estratos de arenitos cozidos intercalados. Paraná. 


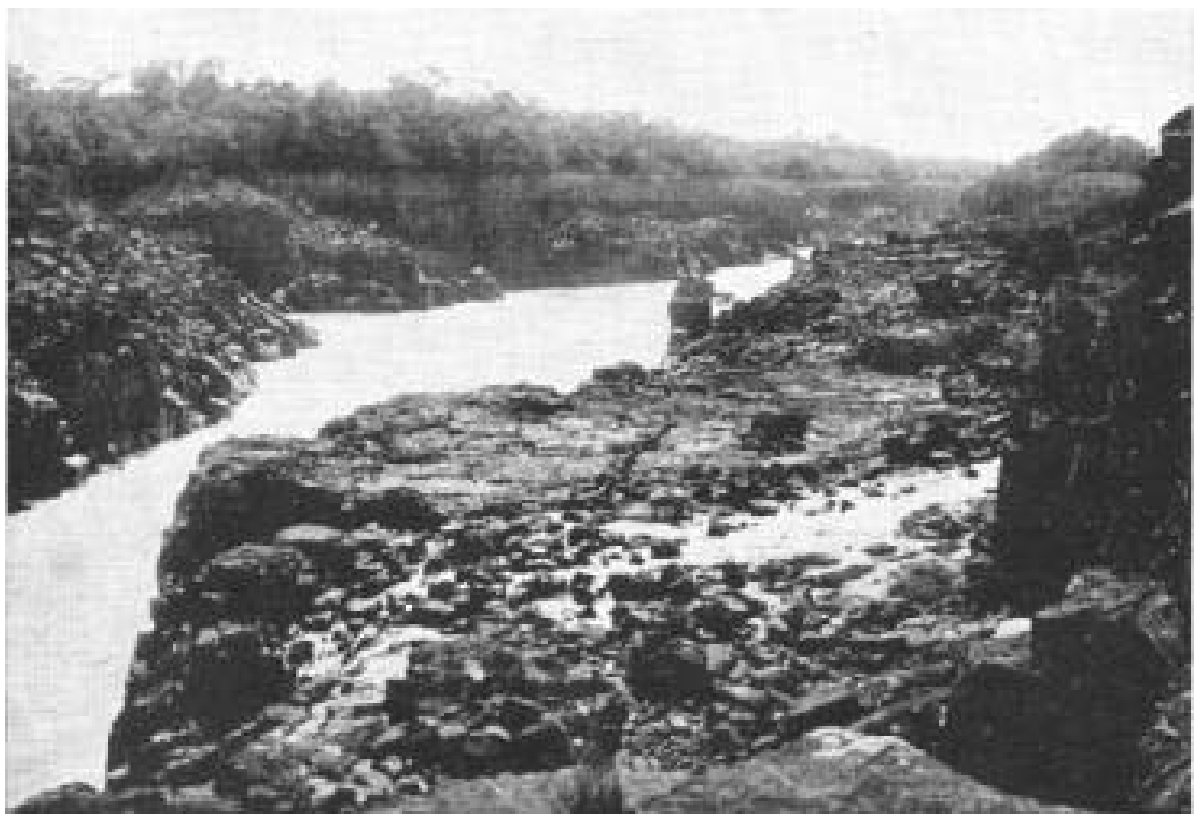

Fig. 43 - Terceiro planalto. O estreito cañon de $80 \mathrm{~m}$ de largura do rápido abaixo das Sete Quedas, em Guaíra, pelo qual as massas d'água do rio Paraná, de uma largura de $5 \mathrm{~km}$ acima dos saltos, passam espremidas com enorme energia. Paraná.

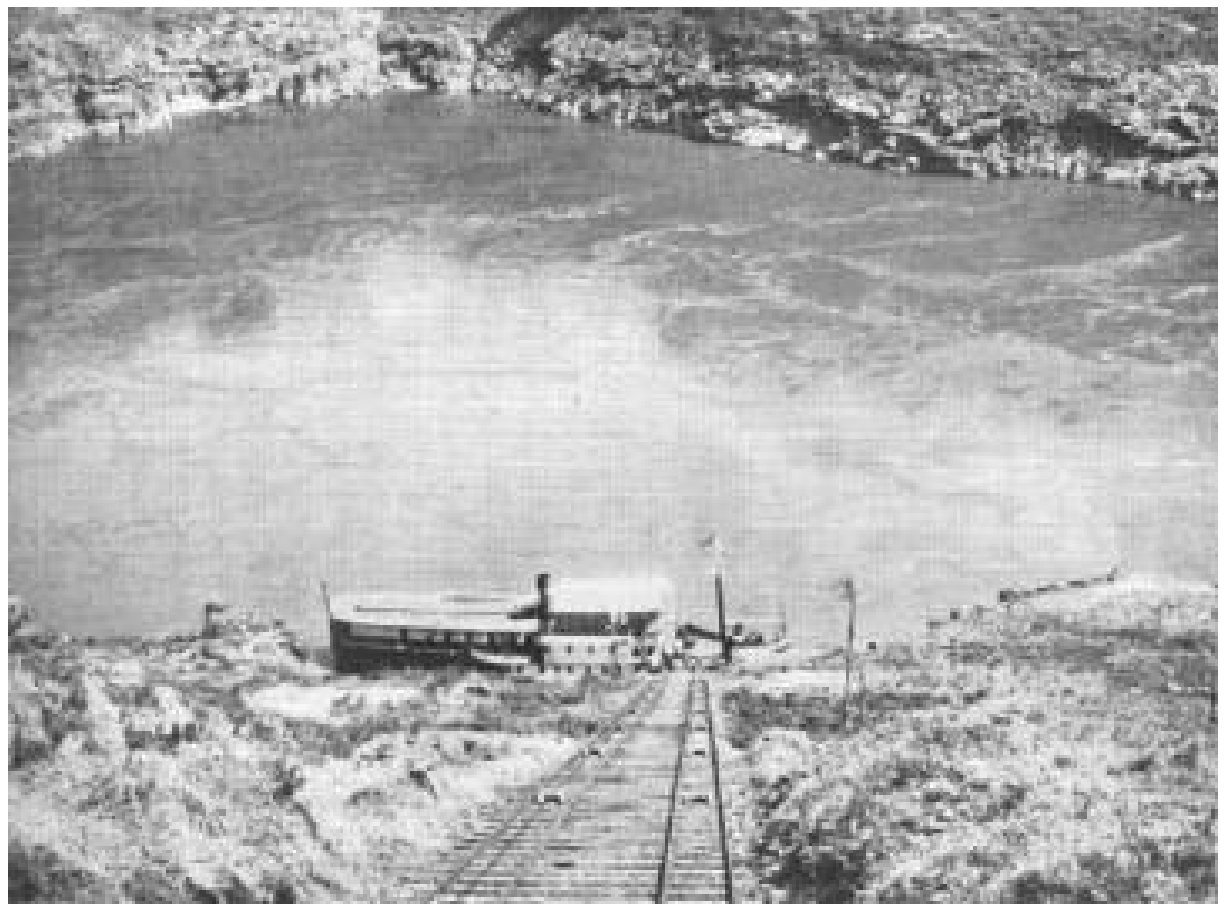

Fig. 44 - Terceiro planalto. O rio Paraná abaixo dos rápidos das Sete Quedas em Porto Mendes. (nível d'água $=105$ m s.n.m.). Paraná. 


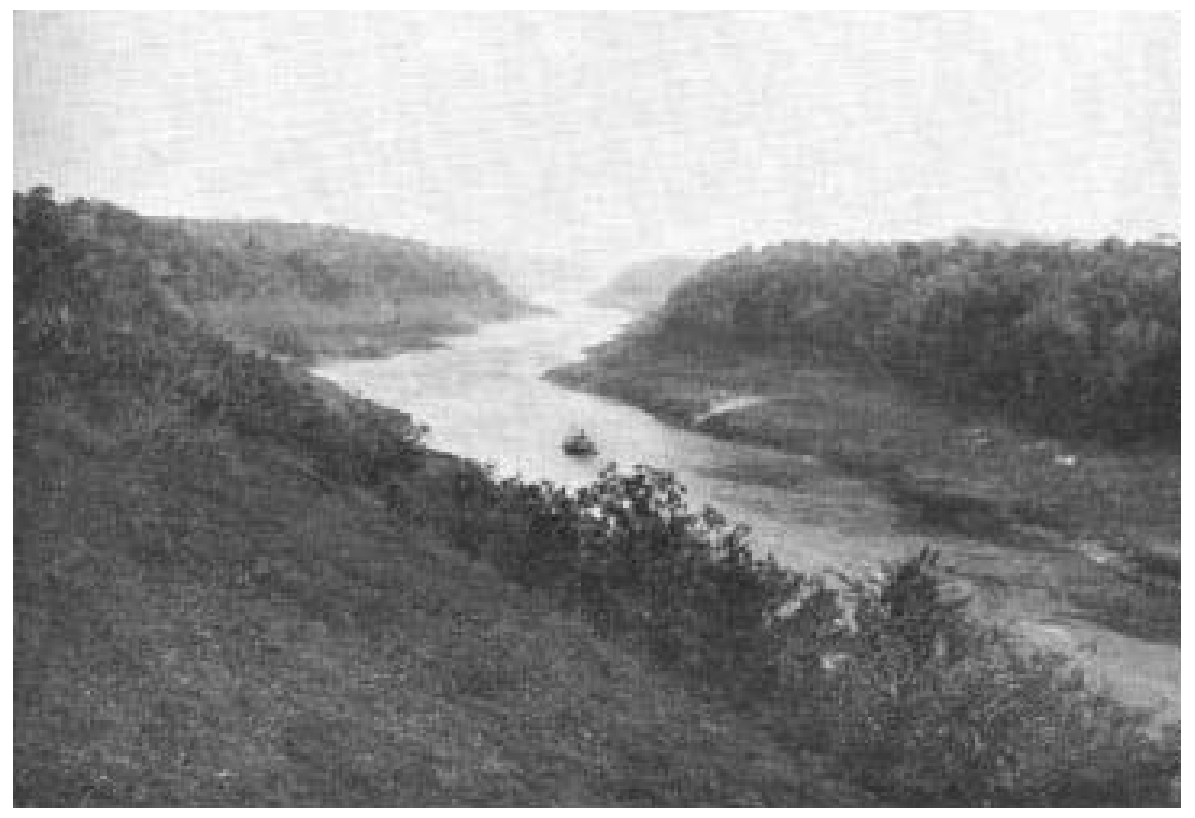

Fig. 45 - Terceiro planalto. Cañon do rio Paraná em Porto Britânia (nível d'água = 89 m s.n.m.). Paraná.

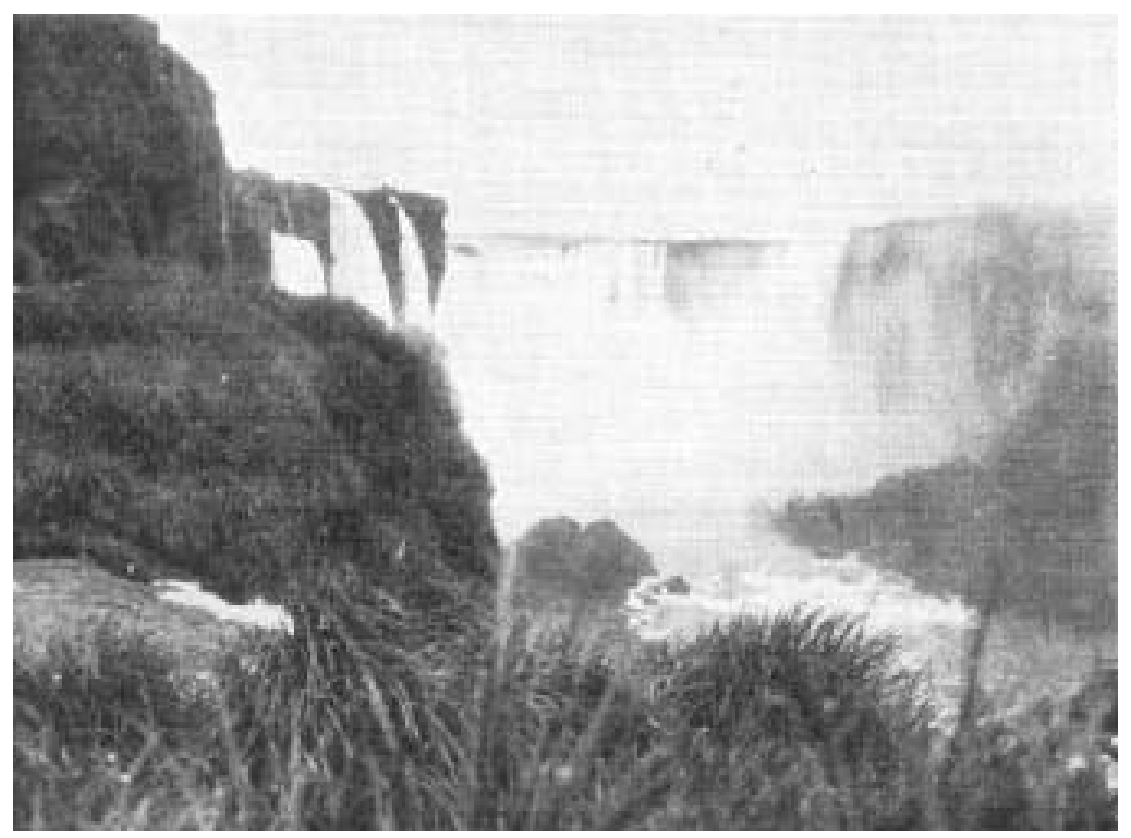

Fig. 46 - Terceiro planalto. Salto Santa Maria no rio Iguaçu com a garganta do Diabo. (Altura da queda $=71 \mathrm{~m}$ ). Paraná. 


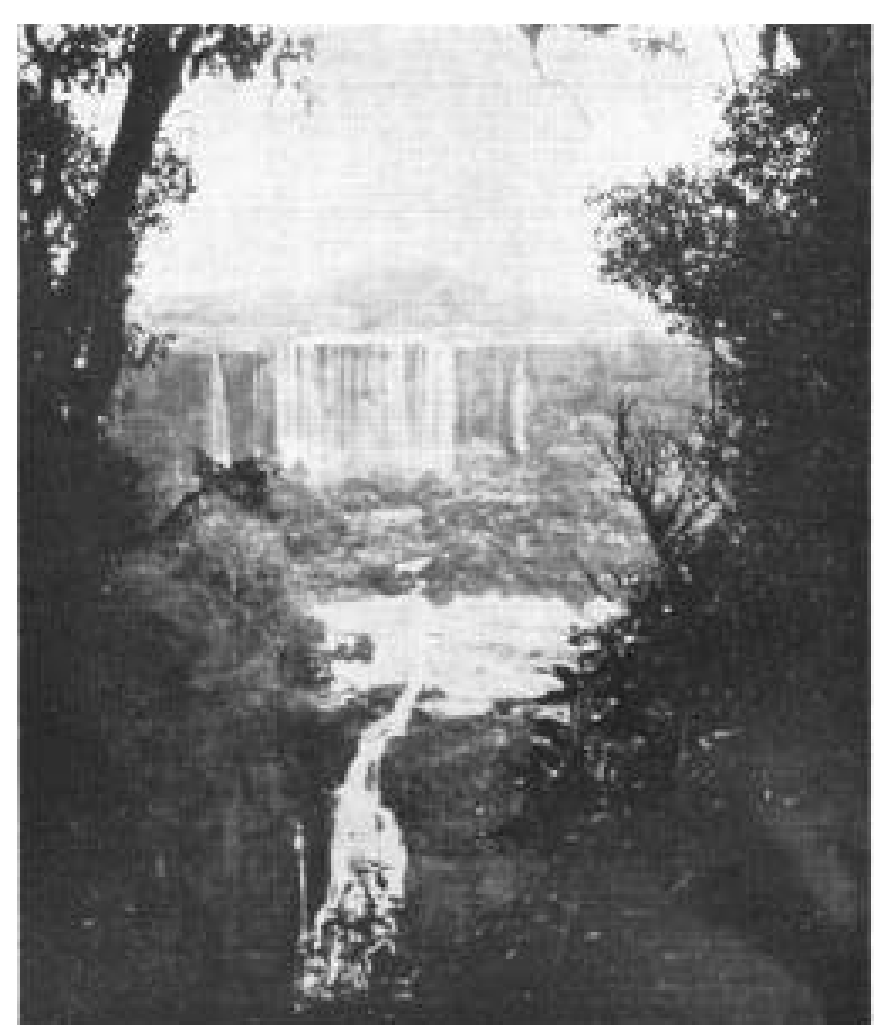

Fig. 47 - Terceiro planalto.Parte dos saltos Santa Maria no rio Iguaçu, denominada "Os três Mosqueteiros". Paraná.

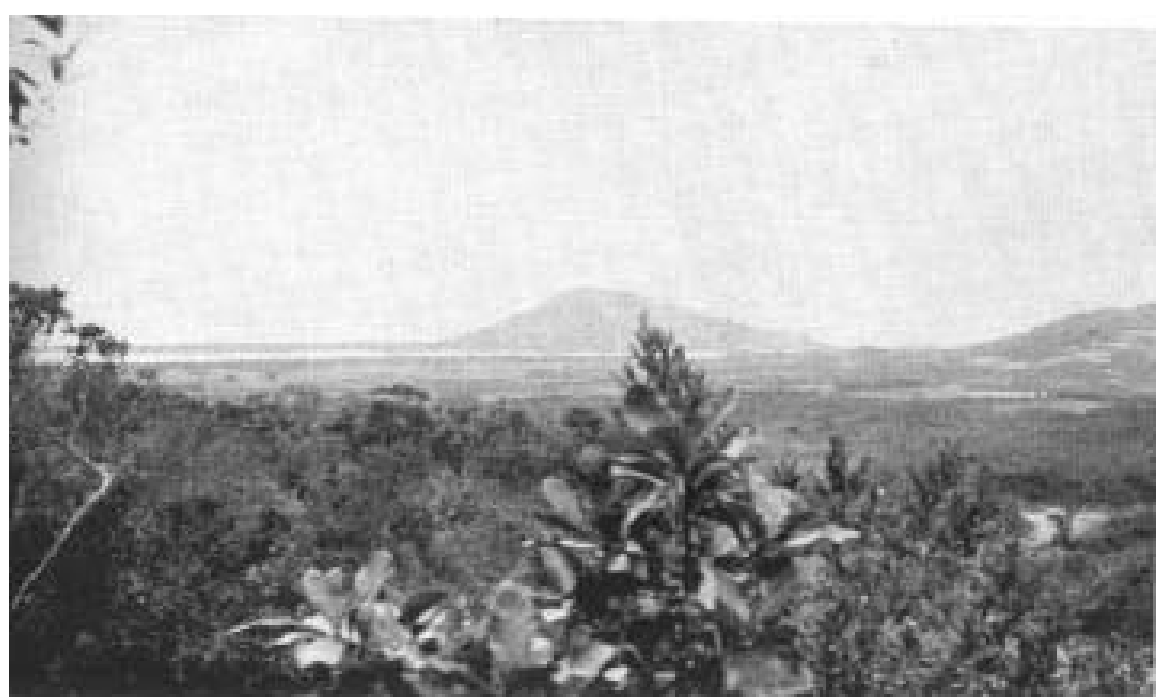

Fig. 48 - Ilha Santa Catarina. Ilhas gnáissicas ligadas entre si pela sedimentação marinha; planícies arenosas e campo de dunas na praia dos Ingleses. Santa Catarina. 


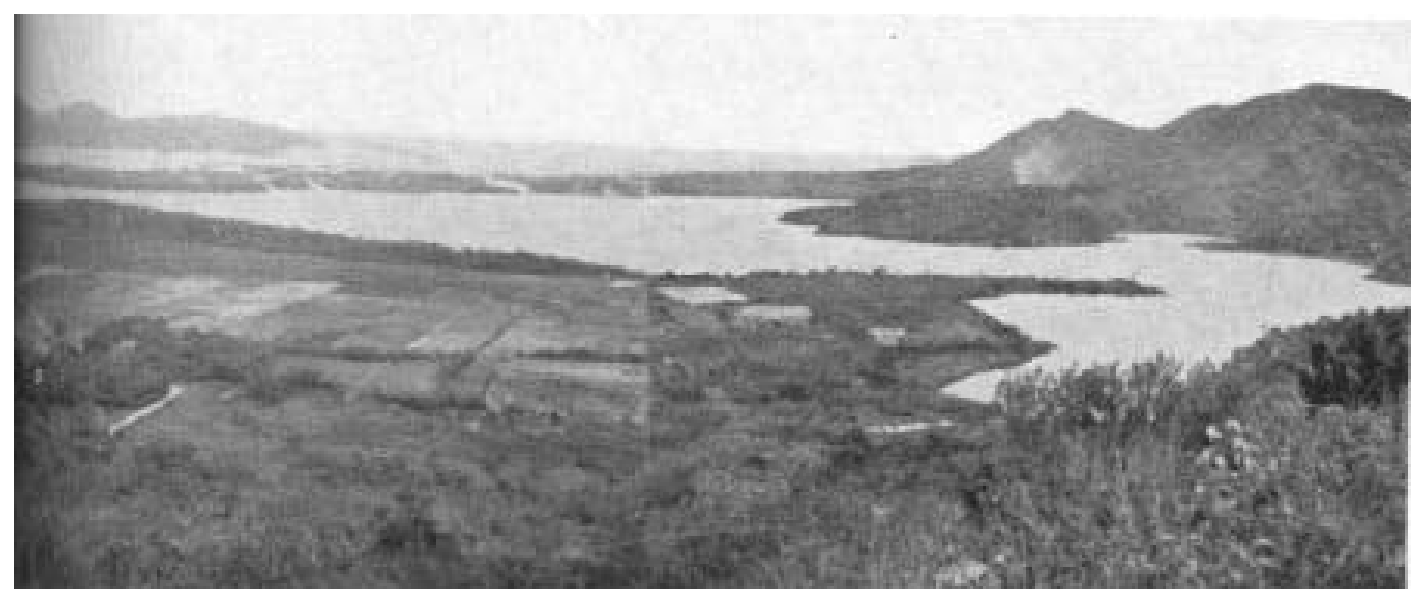

Fig. 49 - Ilha Santa Catarina. A lagoa como exemplo típico de uma baia antiga, atualmente isolada do mar pela sedimentação recente. No primeiro plano: planície de aluviões. Ao fundo à esquerda diante das elevações gnáissicas: um campo de dunas. Santa Catarina.

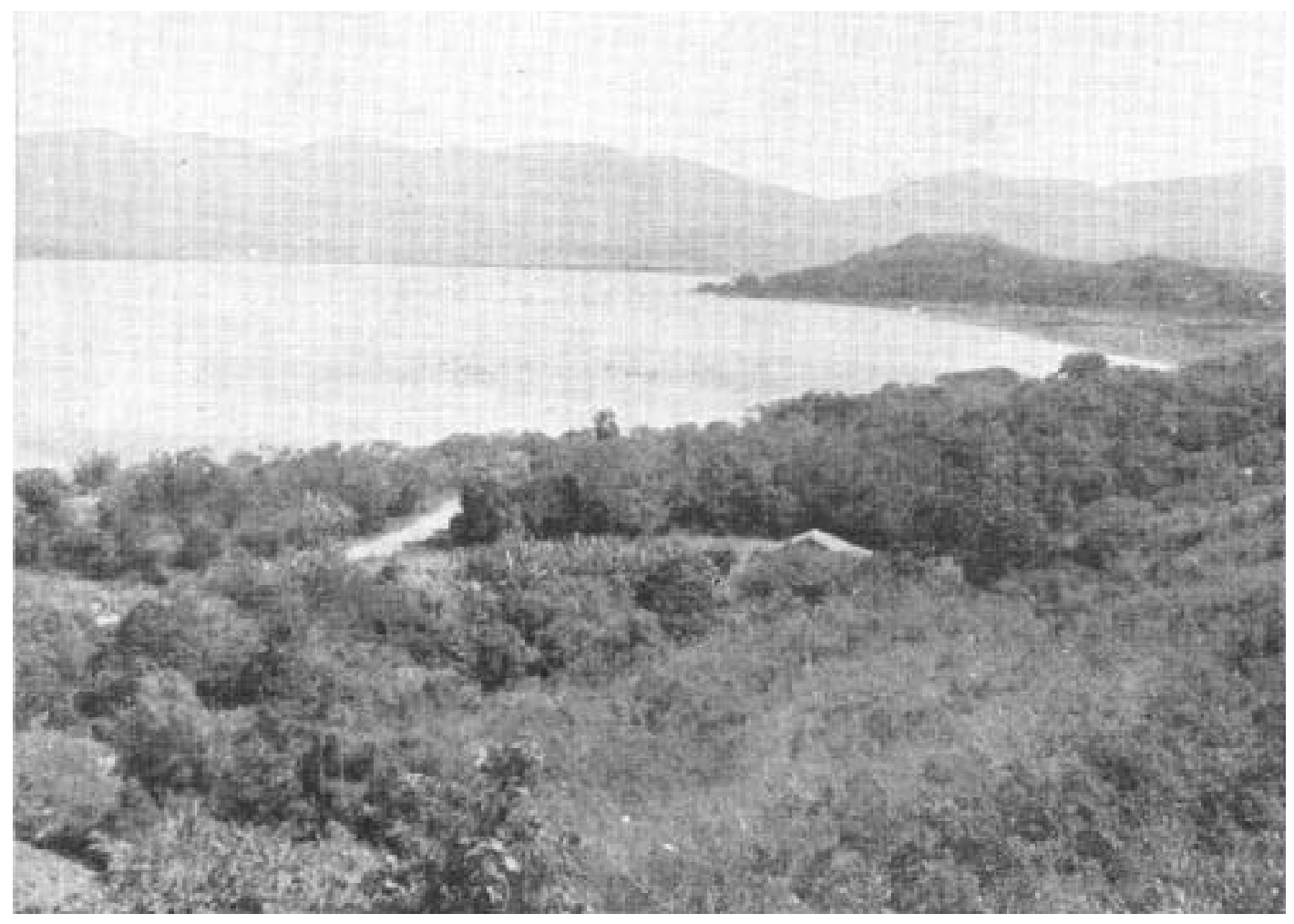

Fig. 50 - Litoral. Parte oeste da baia de ingressão marinha de Laguna, entre Imaruí e Aratingaúba. Santa Catarina. 


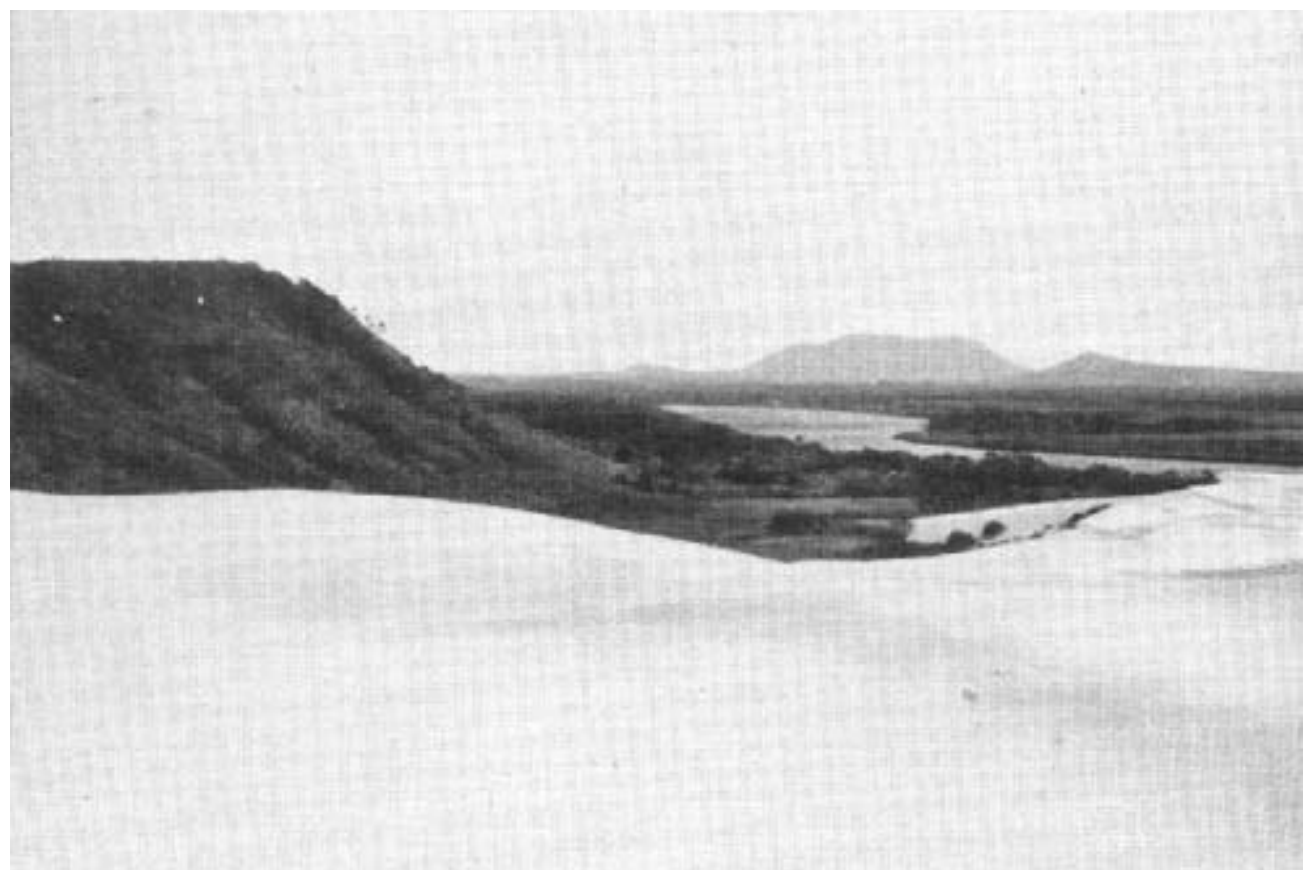

Fig. 51 - Litoral. O rio Araranguá. Ao fundo o morro Mãe Luzia (248 m s.n.m.), constituído de camadas Terezina e Rio do Rasto da série Passa Dois. À esquerda: a borda da meseta do morro dos Conventos. Santa Catarina.

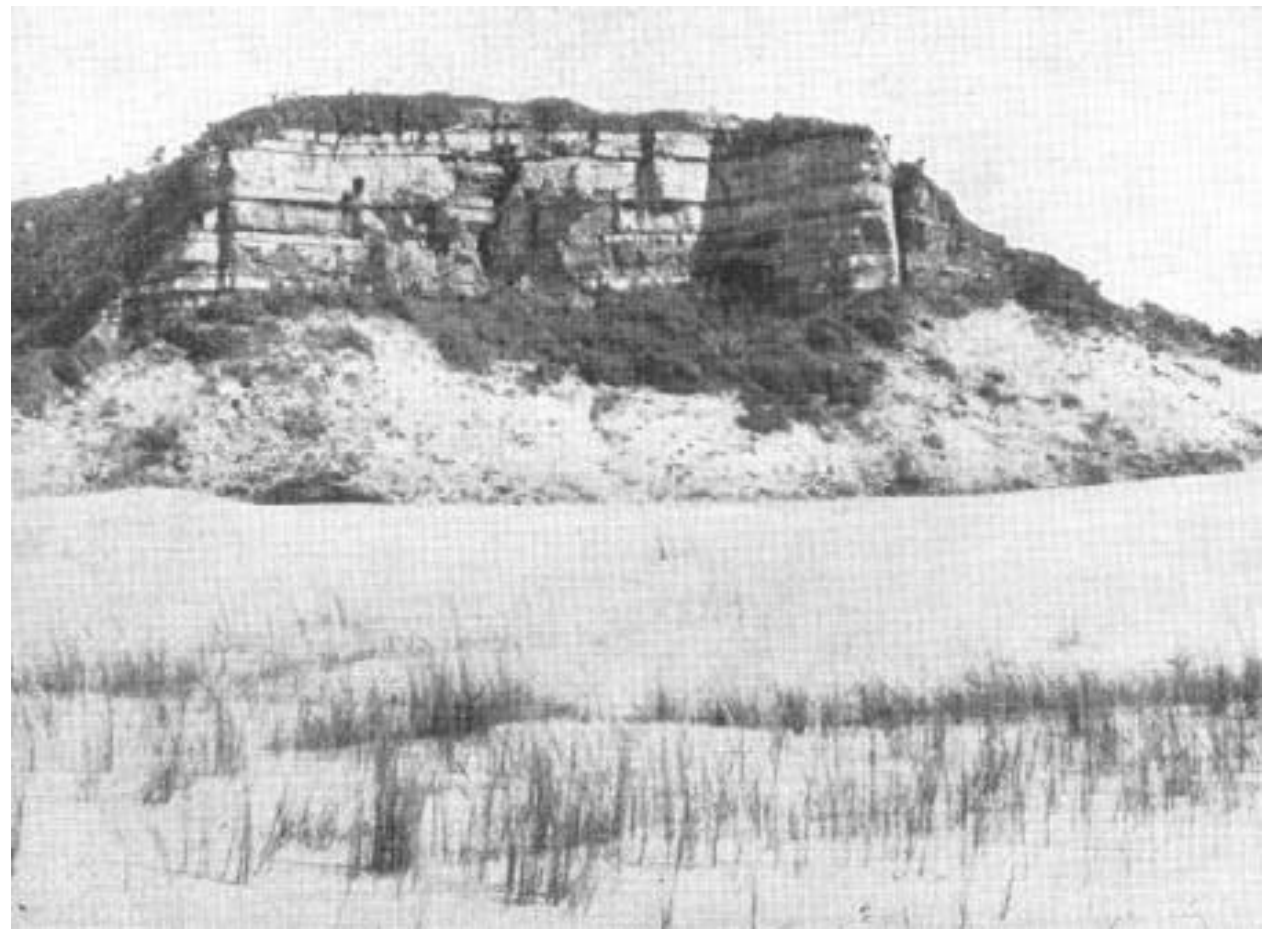

Fig. 52 - Litoral. O morro dos Conventos (83 m s.n.m.), uma meseta de camadas gonduânicas, do grupo Rio do Rasto da série Passa Dois, na praia ao sul do rio Araranguá. Santa Catarina. 


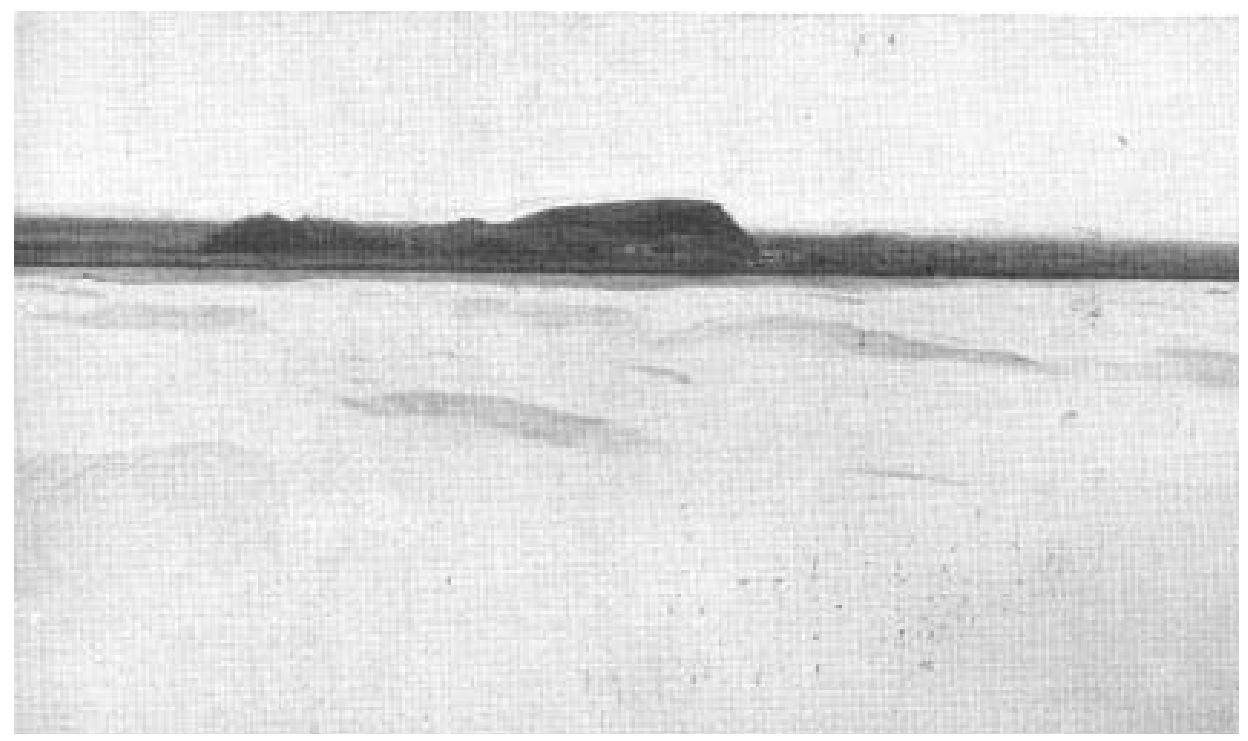

Fig. 53 - Litoral. Campos de dunas a sueste do rio Araranguá. No centro o morro Agudo $(50 \mathrm{~m})$ ao norte do rio Araranguá, constituído por camadas do grupo rio do Rasto da série Passa Dois. Santa Catarina.

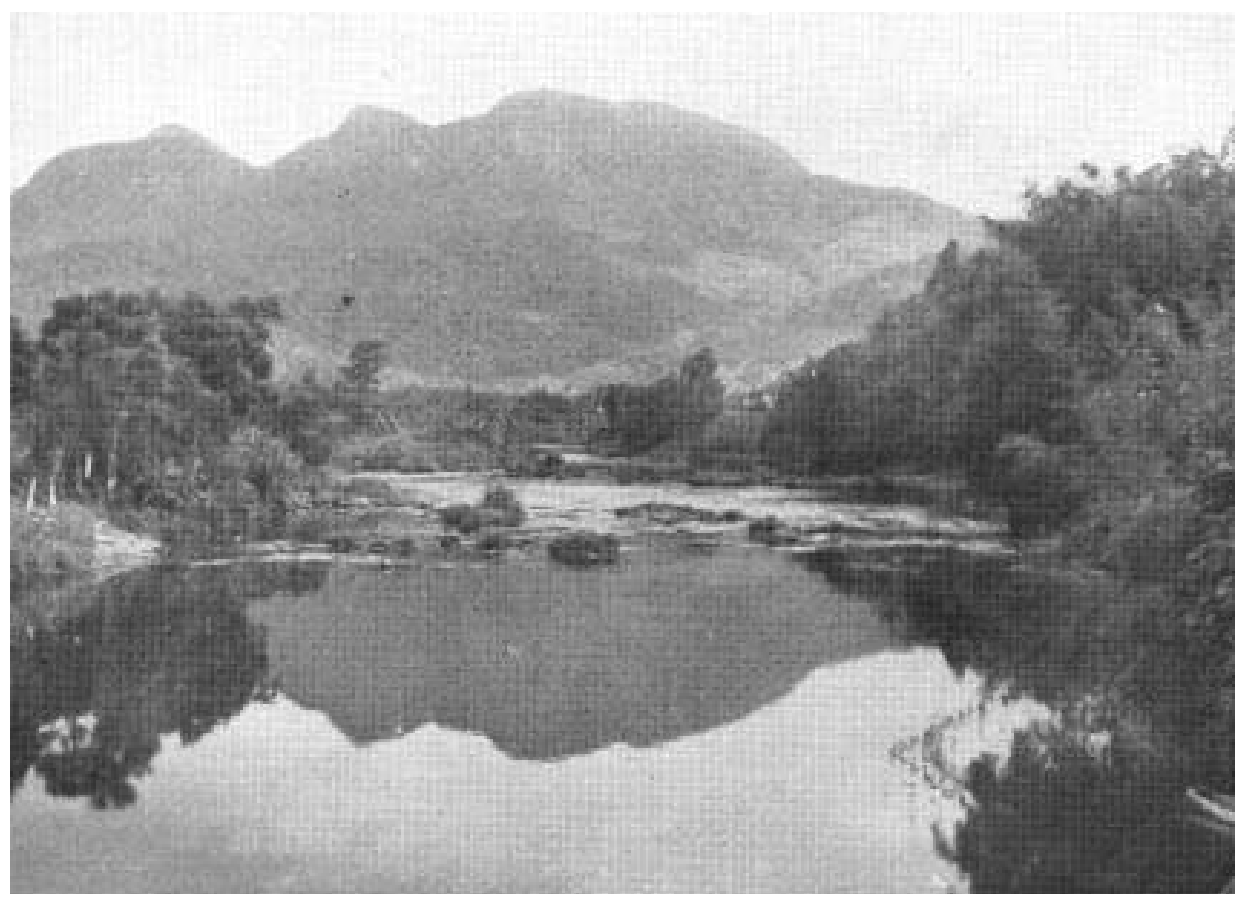

Fig. 54 - Litoral. O rio Itapocú e a Serra Jaraguá, elevação do complexo cristalino com crista truncada pelos restos de peneplano pré-gonduânico. Santa Catarina. 


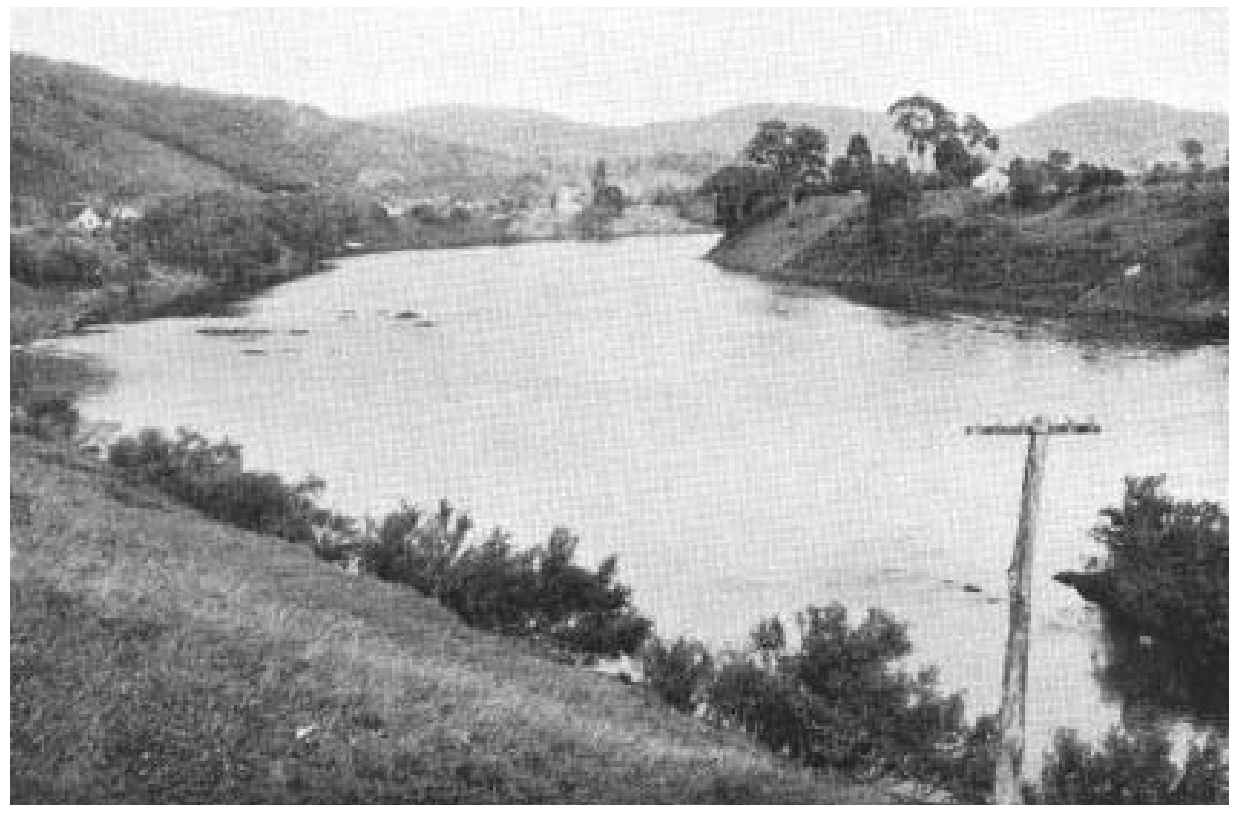

Fig. 55 - Litoral. O rio Itajaí-Açú entre Blumenau e Gaspar, correndo sobre estratos da série Itajaí. À direita: planos aluviais do quaternário; à esquerda: elevações constituídas por camadas areno-argilosas da série Itajaí. Santa Catarina.

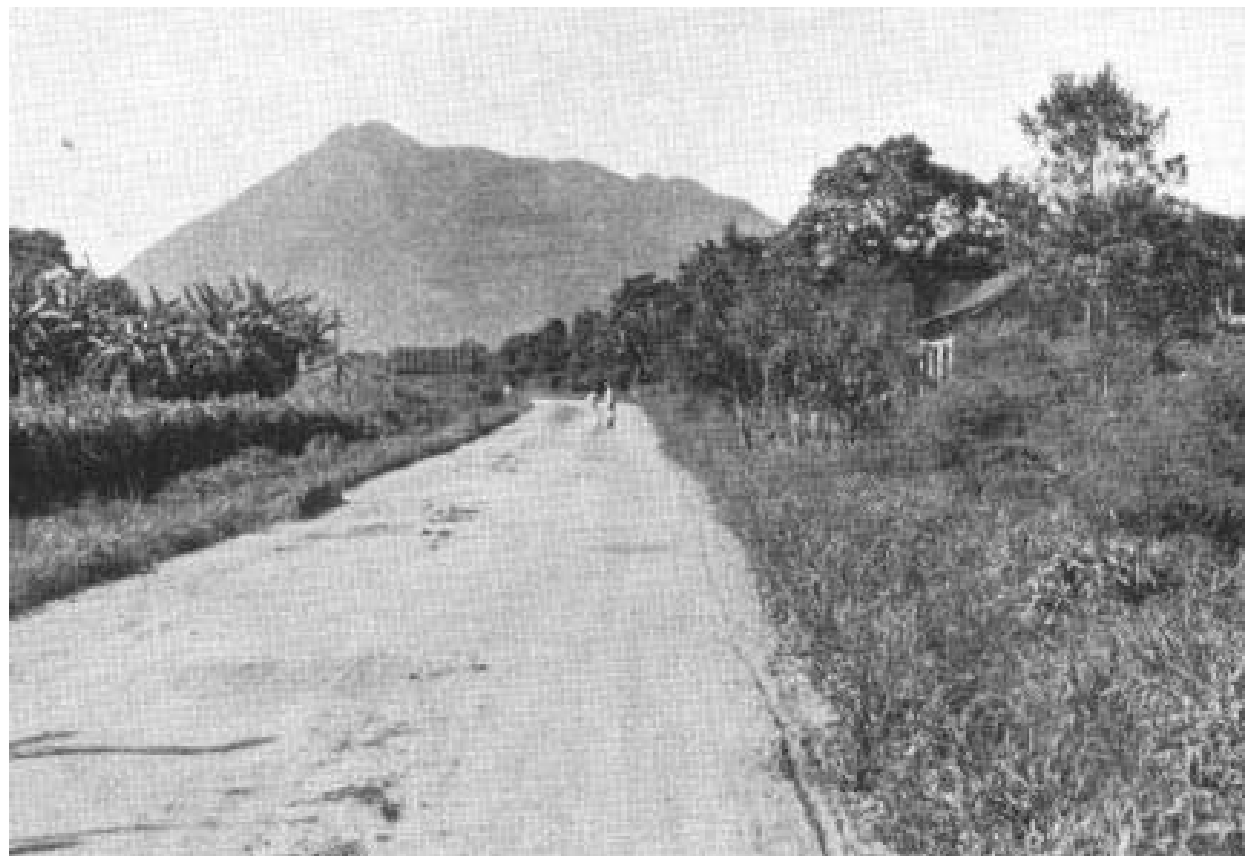

Fig. 56 - Litoral. O morro Cambirela (cerca 1080 m s.n.m.), elevação gnaisgranítica isolada da Serra do Mar, diretamente na praia entre Palhoça e Enseada de Brito. Santa Catarina. 


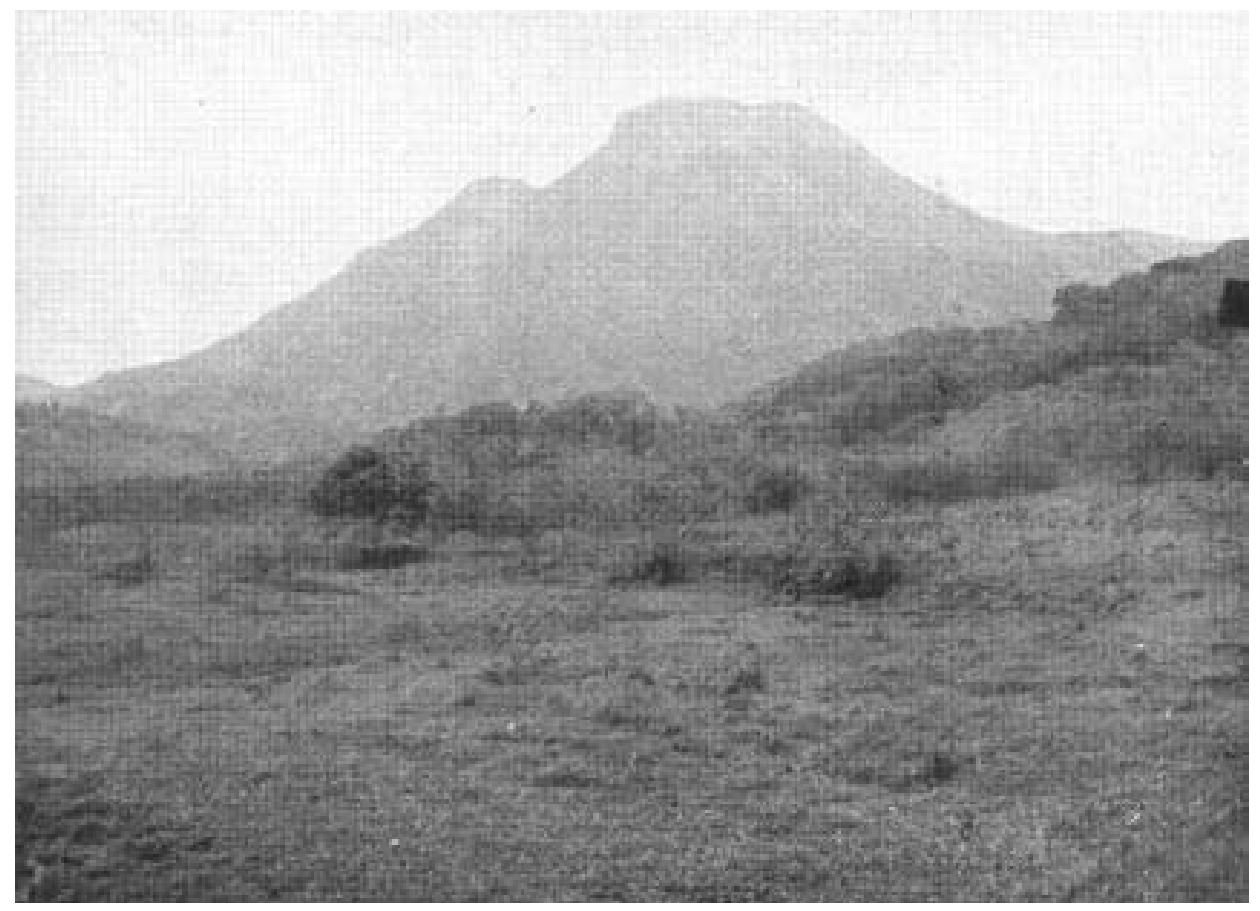

Fig. 57 - Litoral. Serra dos Tijucas. Morro em forma de cone, truncado pelos restos da peneplanície pré-gonduânica. Santa Catarina.

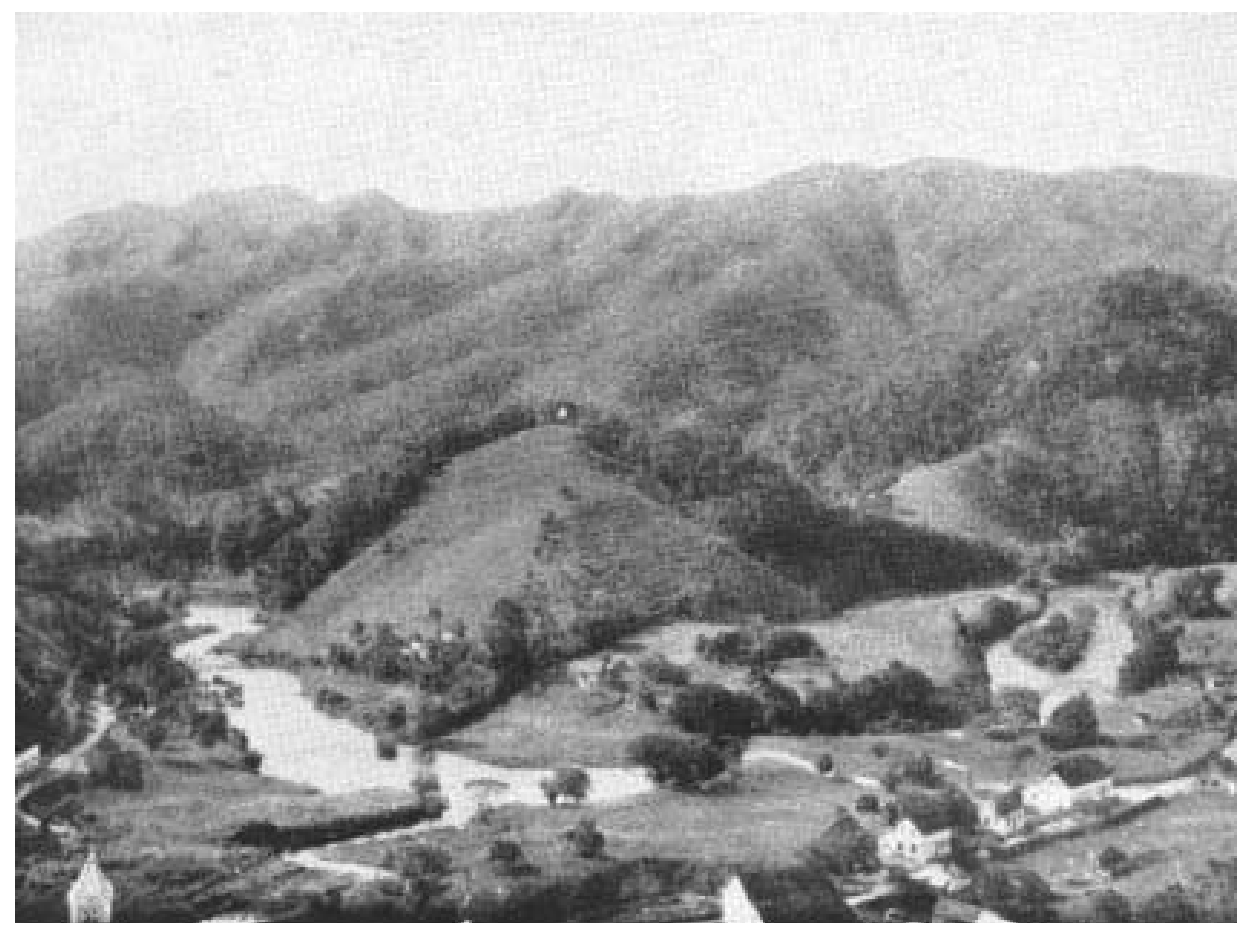

Fig. 58 - Litoral. A Serra Porto Franco (638 m) no vale do rio Itajaí-Mirim, constituída por filitos da série Brusque (= série Minas). Santa Catarina. 


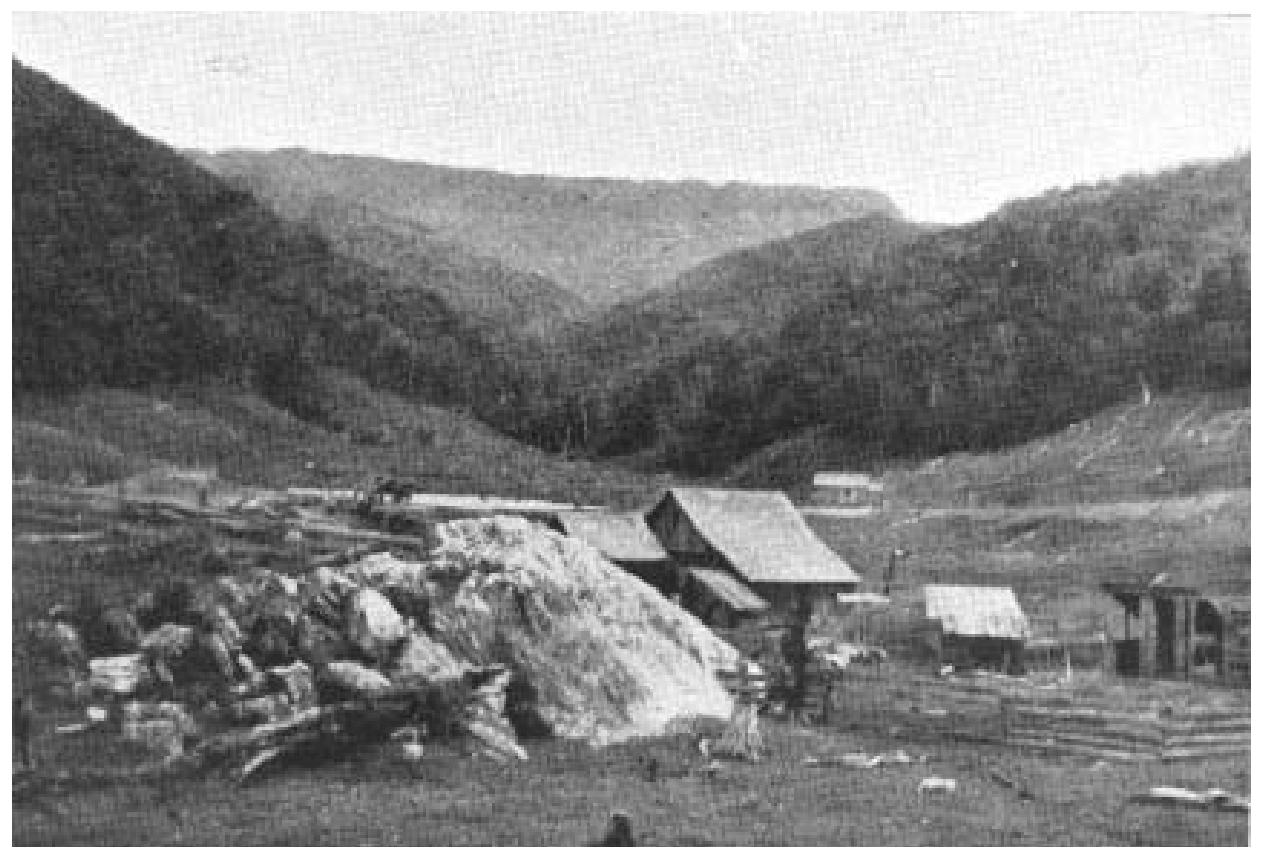

Fig. 59 - Litoral. Meseta isolada de rochas gonduânicas (810 m) em Várzea Grande, nas cabeceiras do ribeirão d'Ouro, vale do rio Itajaí-Mirim; camadas da série Tubarão sobre filitos e calcáreos da série Brusque. Santa Catarina.

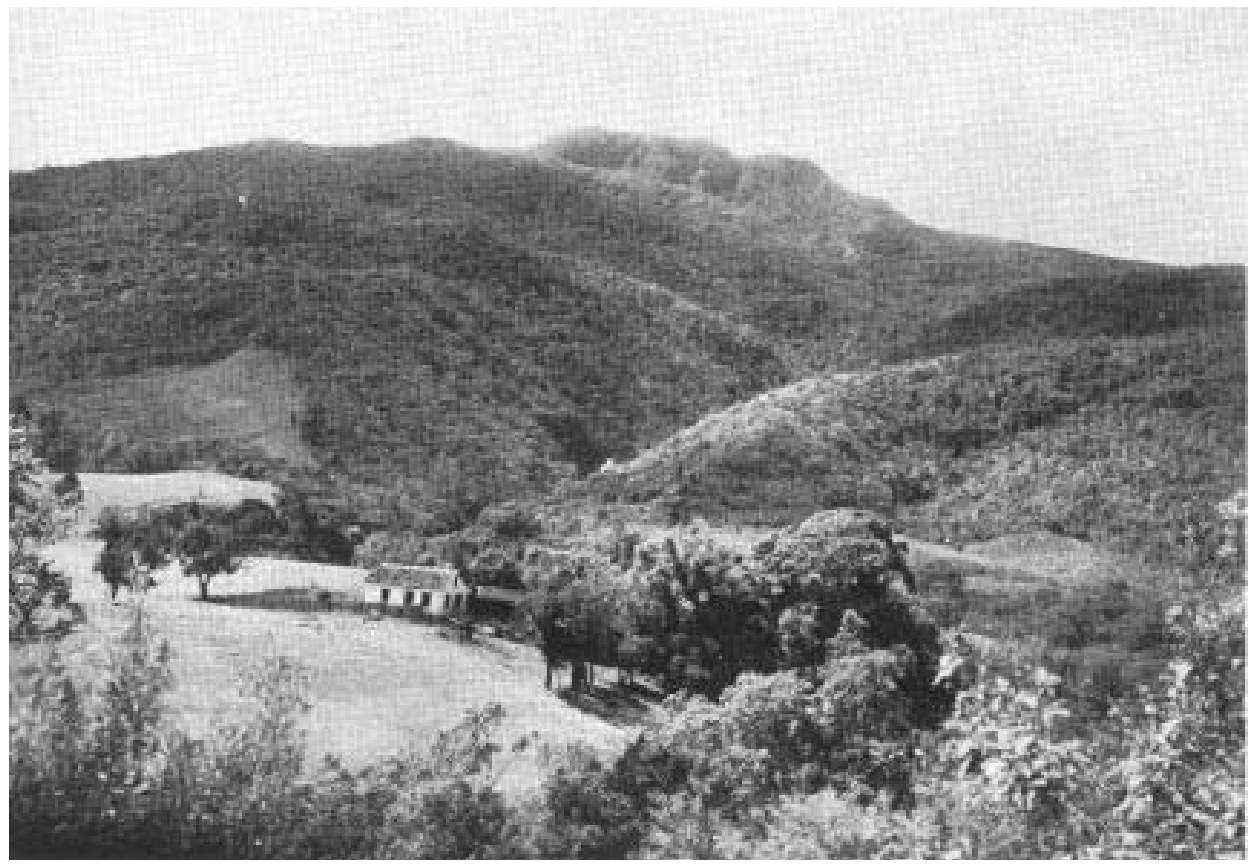

Fig. 60 - Litoral. Serra Taboleiro constituída de gnais-granitos e camadas da série Brusque, truncada pelo peneplano pré-gonduânico. Santa Catarina. 


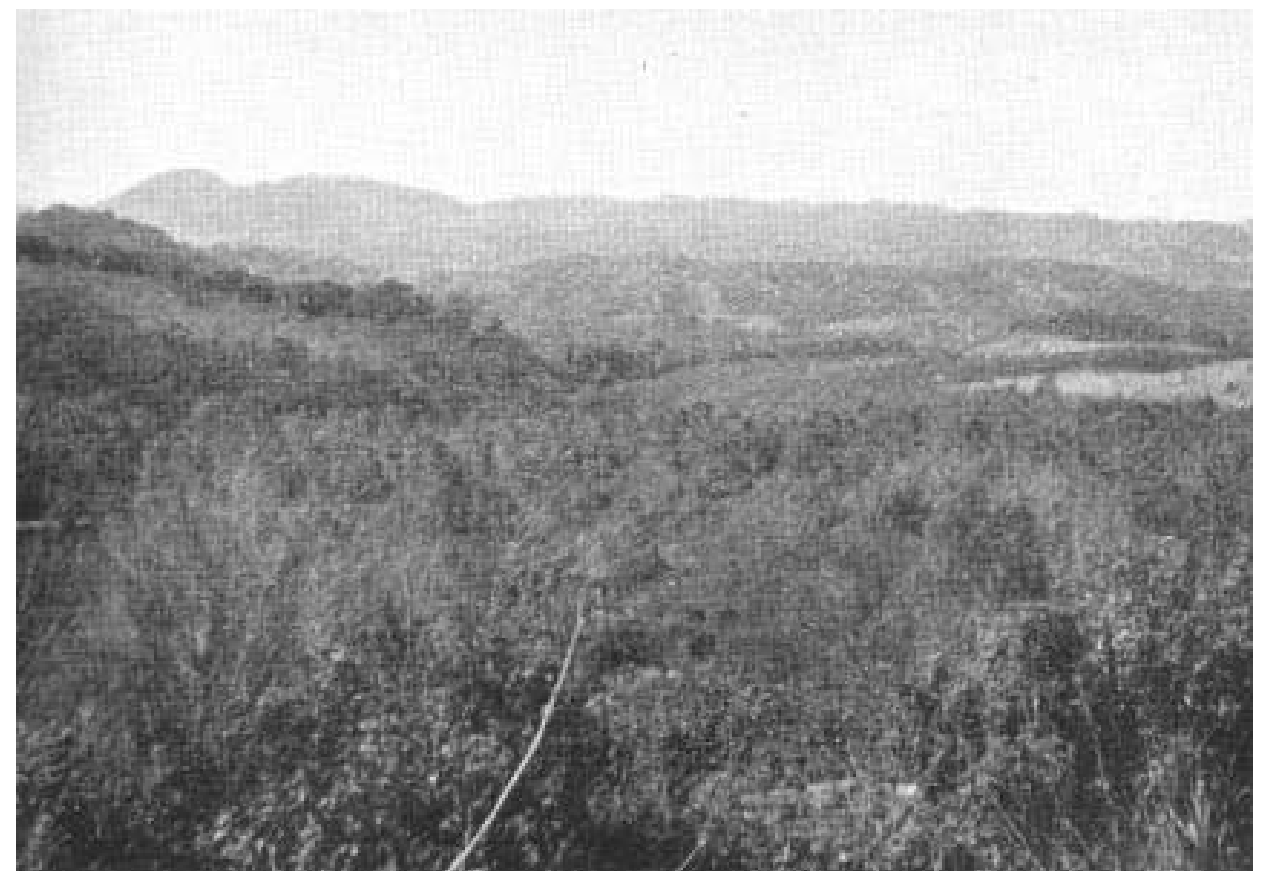

Fig. 61 - Litoral. O peneplano pré-gonduânico, levemente inclinado par W, cortando as elevações graníticas entre Fortuna e Braço do Norte. Santa Catarina.

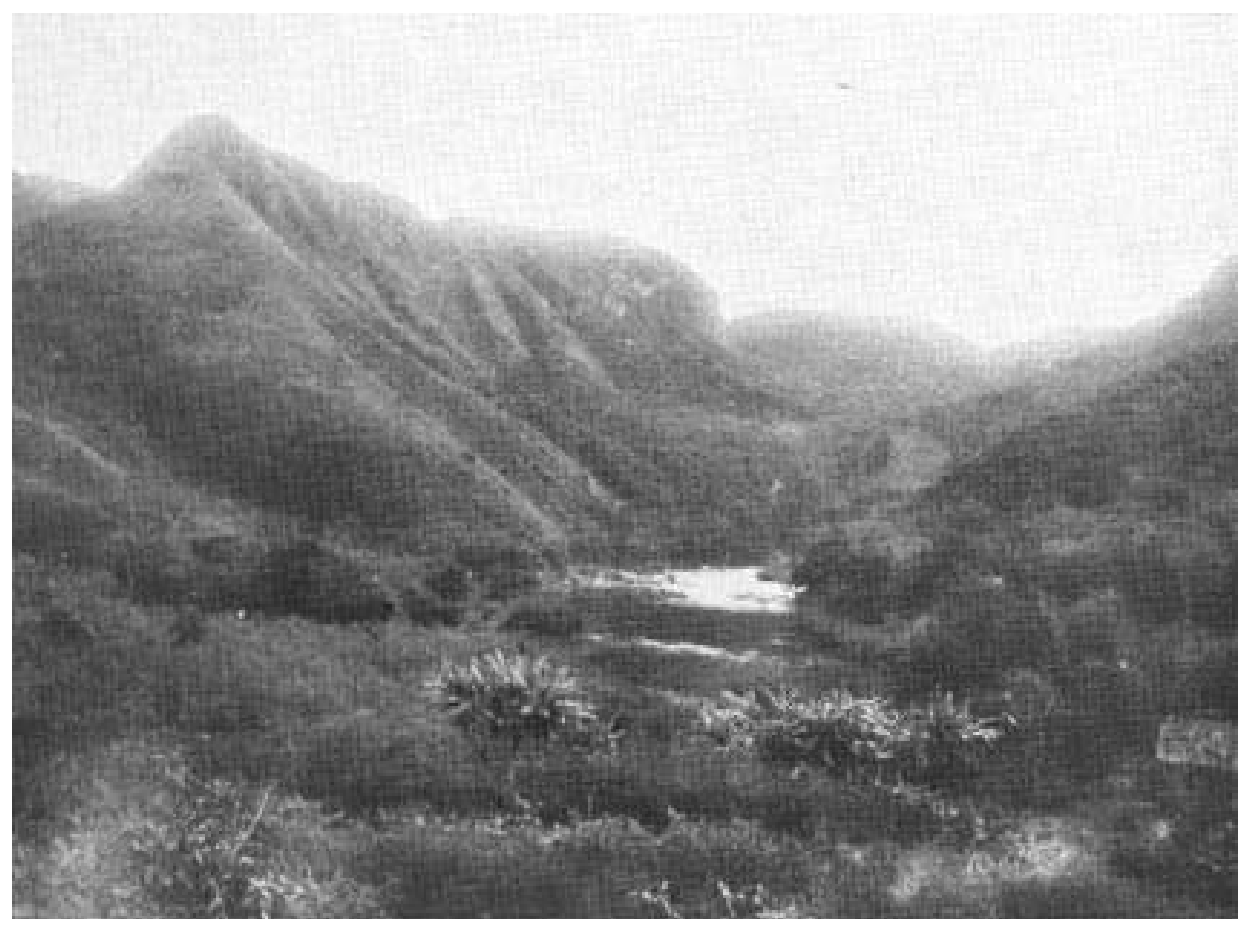

Fig. 62 - Litoral. Vale do rio Itajaí-Açú na zona de distribuição das rochas da série Itajaí, entre Apiuna e Ibirama (ex-Hamônia). Santa Catarina. 


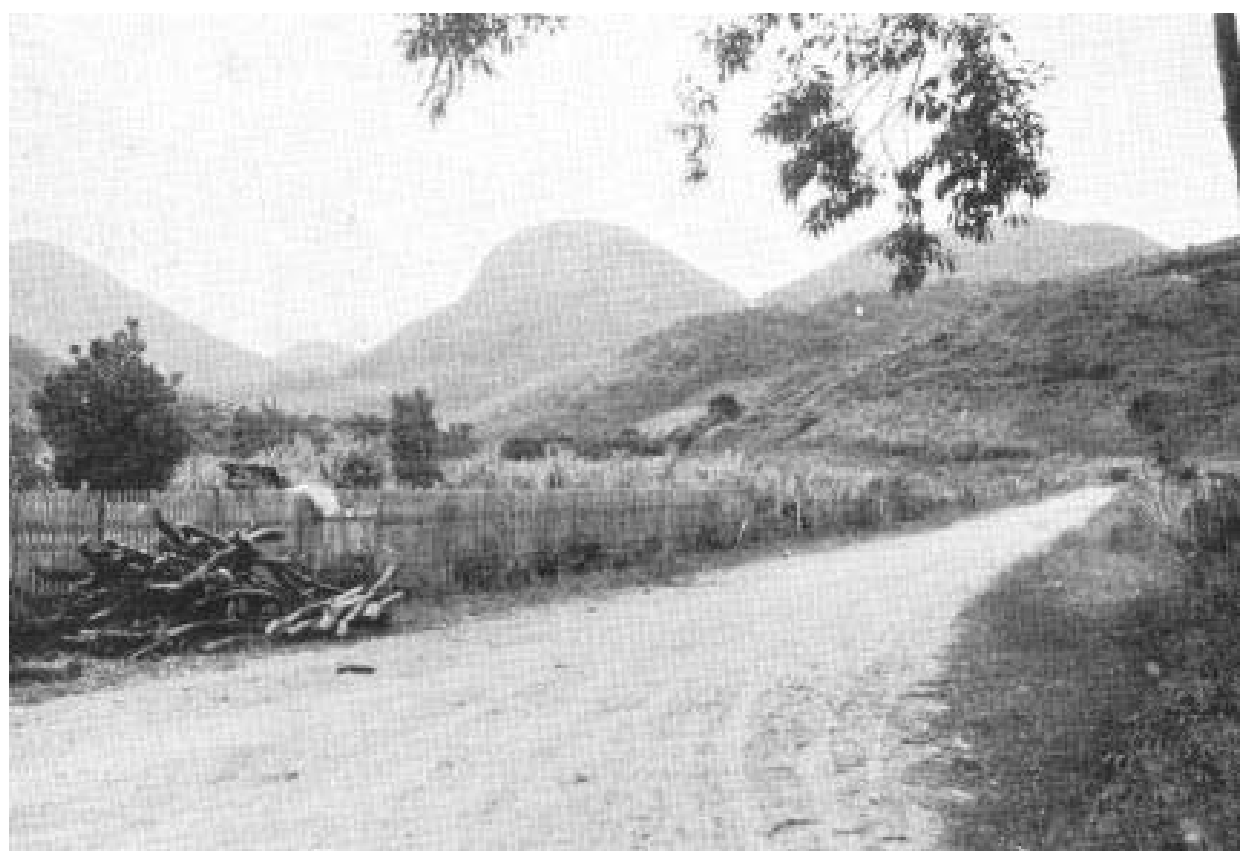

Fig. 63 - Litoral. Formas de elevações constituídas de rochas da série Itajaí em Diamante, no vale do rio Itajaí-Açú. Santa Catarina.

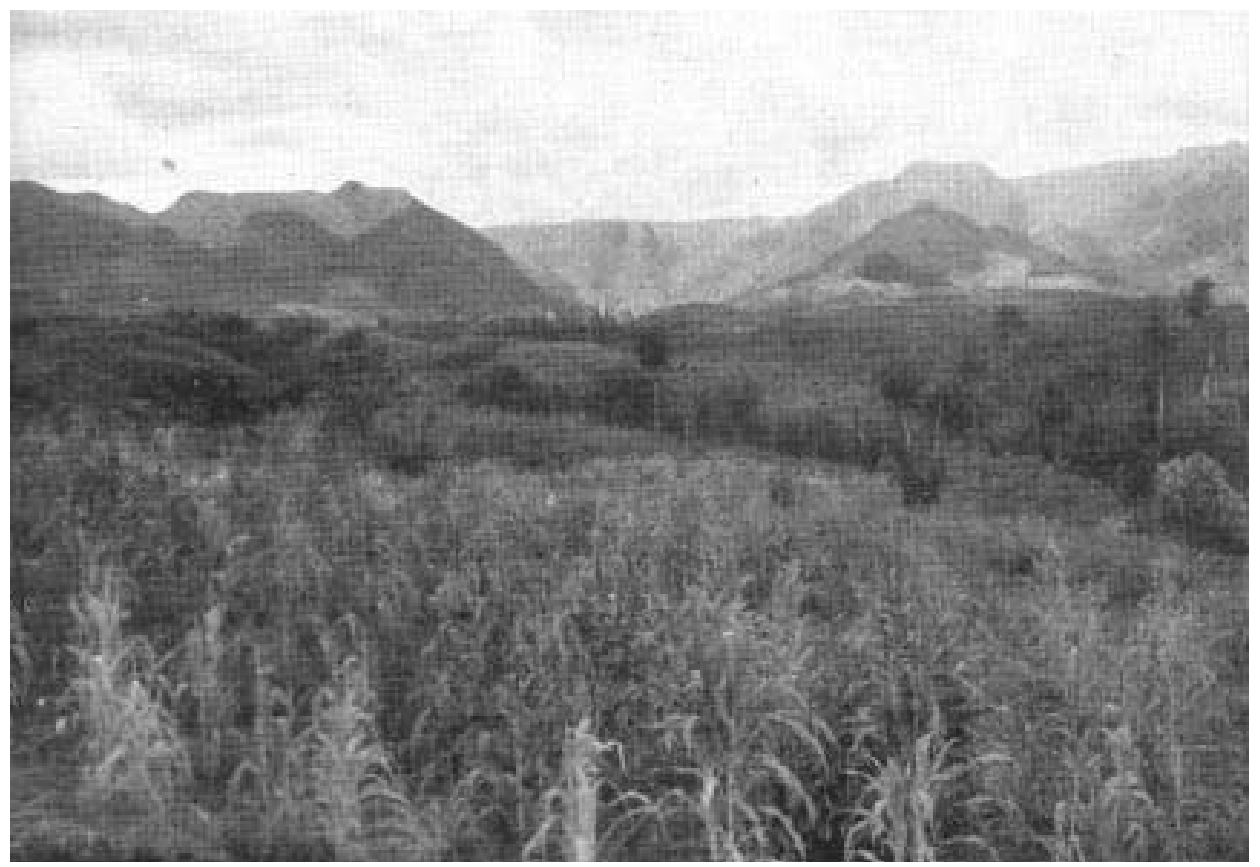

Fig. 64 - Escarpa do planalto.frente da Serra Geral na região do rio do Rasto, a oeste de Lauro Mueller. Santa Catarina. 


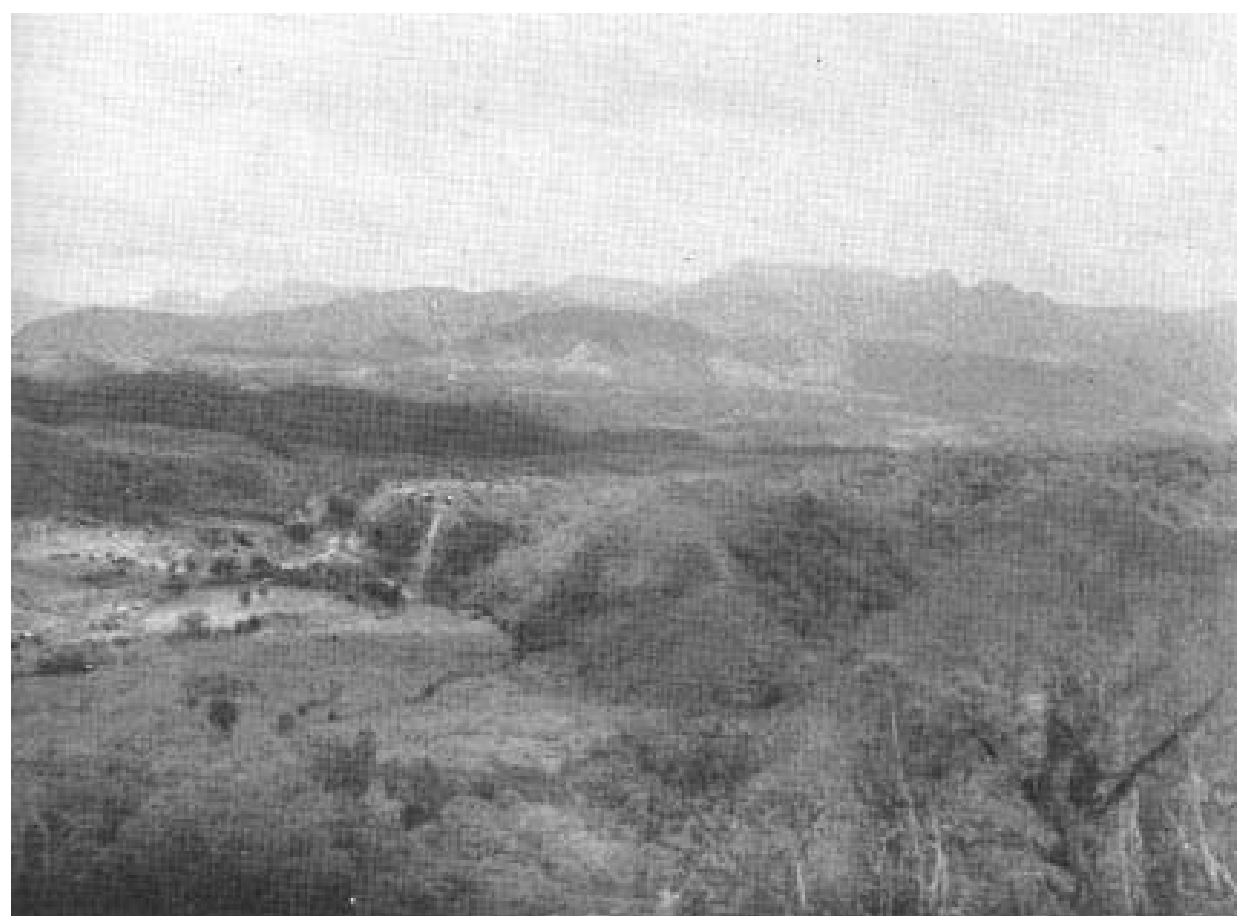

Fig. 65 - Escarpa do planalto. Serra do Oratório (1200 a 1400 m s.n.m.), parte da Serra Geral a sudoeste de Guatá, revelando a seqüência total das camadas gonduânicas, desde a série Tubarão até os lençóis das rochas eruptivas básicas. Santa Catarina.

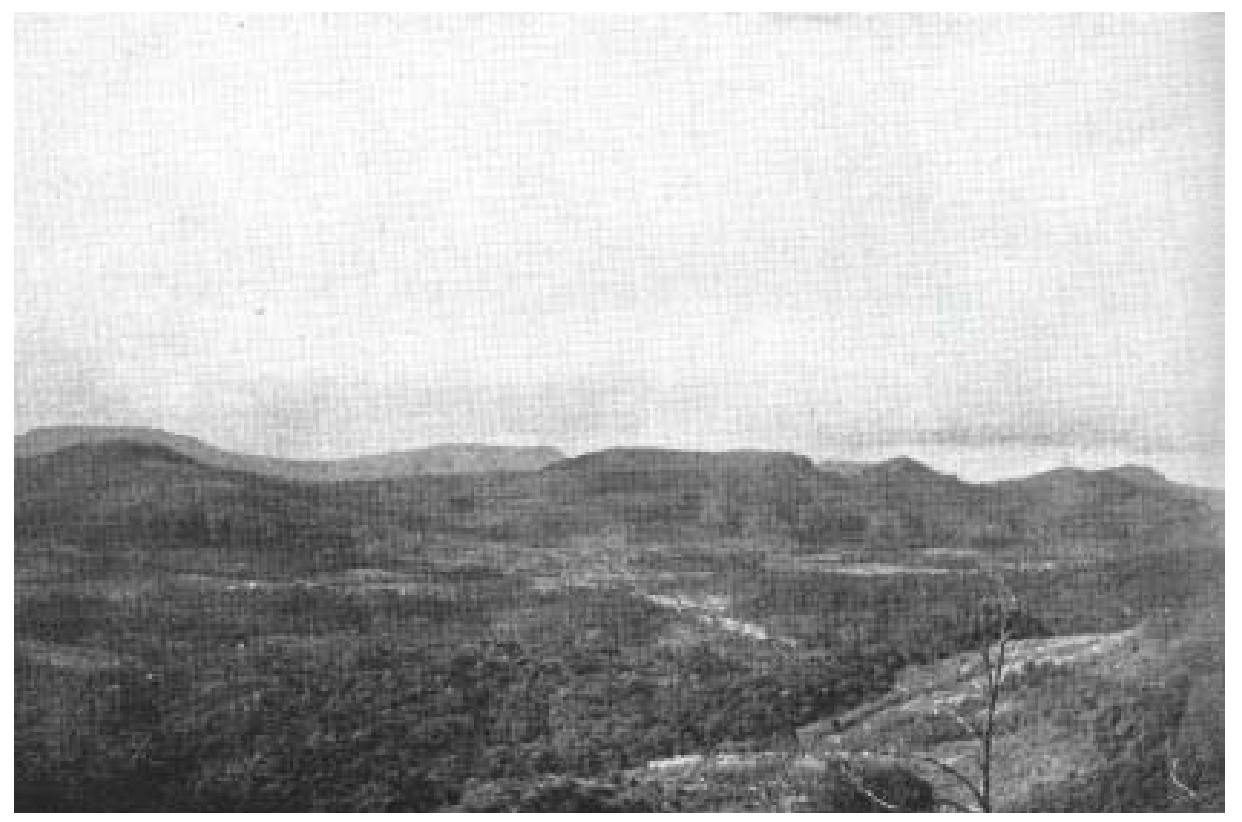

Fig. 66 - Planalto do interior. Mesetas de camadas gonduânicas sobre o planalto na região de Bom Retiro - Santa Clara. Vista tomada do morro do Panelão na cota de $1250 \mathrm{~m}$ em direção norte. Santa Catarina. 


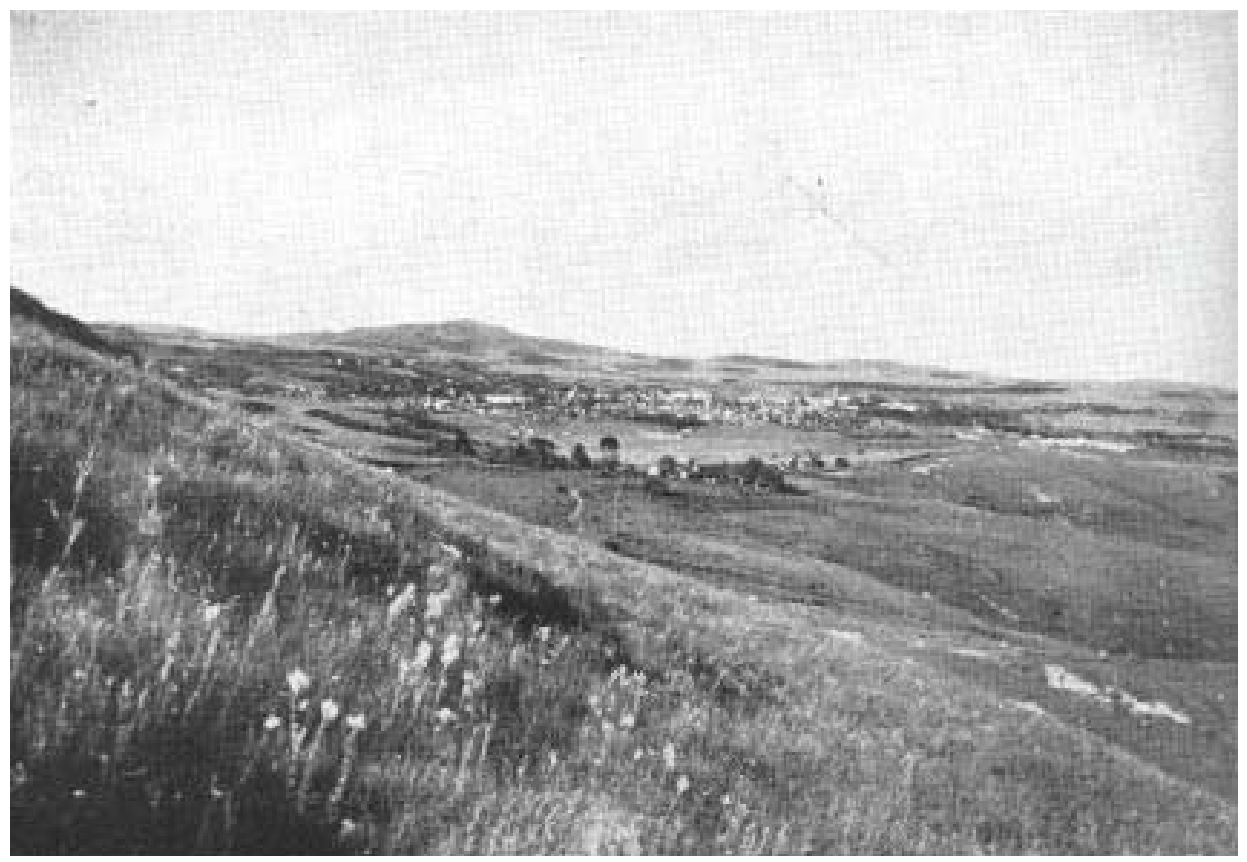

Fig. 67 - Planalto do interior. Lajes $(925 \mathrm{~m})$ com o morro do Tributo $(1220 \mathrm{~m})$ ao fundo; constituído por um stock de fonolito e tinguaito dentro dos sedimentos gonduânicos. A direita no primeiro plano: afloramentos do arenito Botucatu. Santa Catarina.

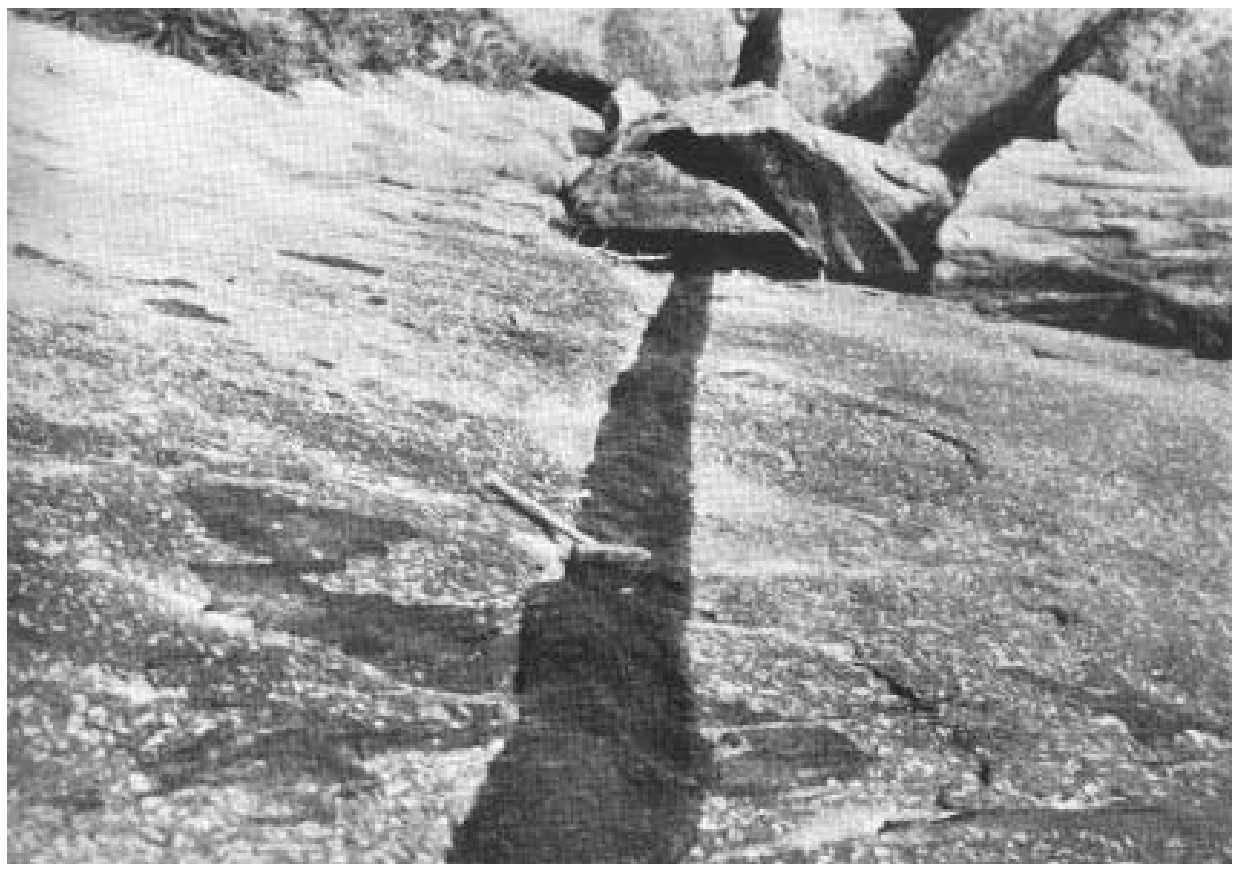

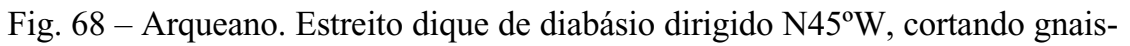
granito-pórfiro com inclusões de biotita-gnais, na ilha do Farol, Caiobá Paraná. Santa Catarina. 


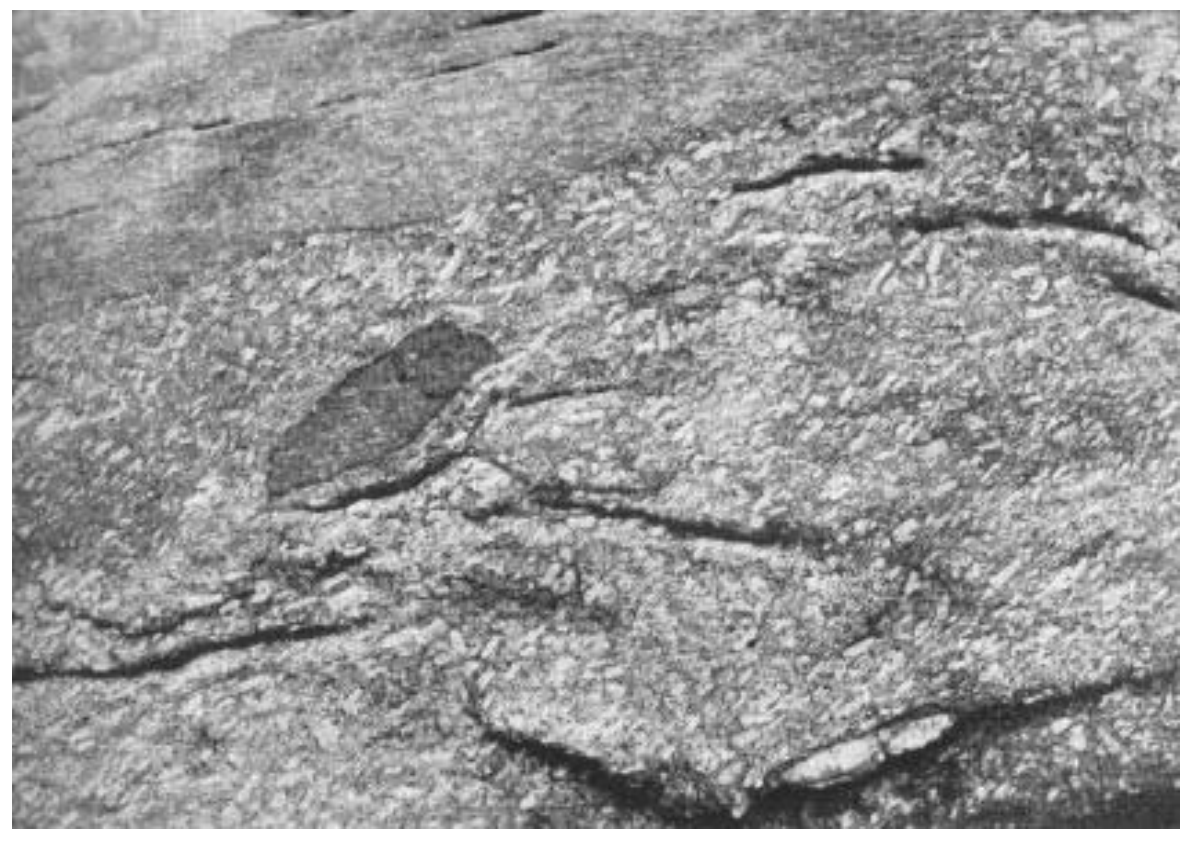

Fig. 69 - Arqueano. Gnais-granito-pórfiro com uma inclusão de biotita-gnais em contacto nítido com biotita-gnais mais antigo, no morro Caiobá - Paraná. Santa Catarina.

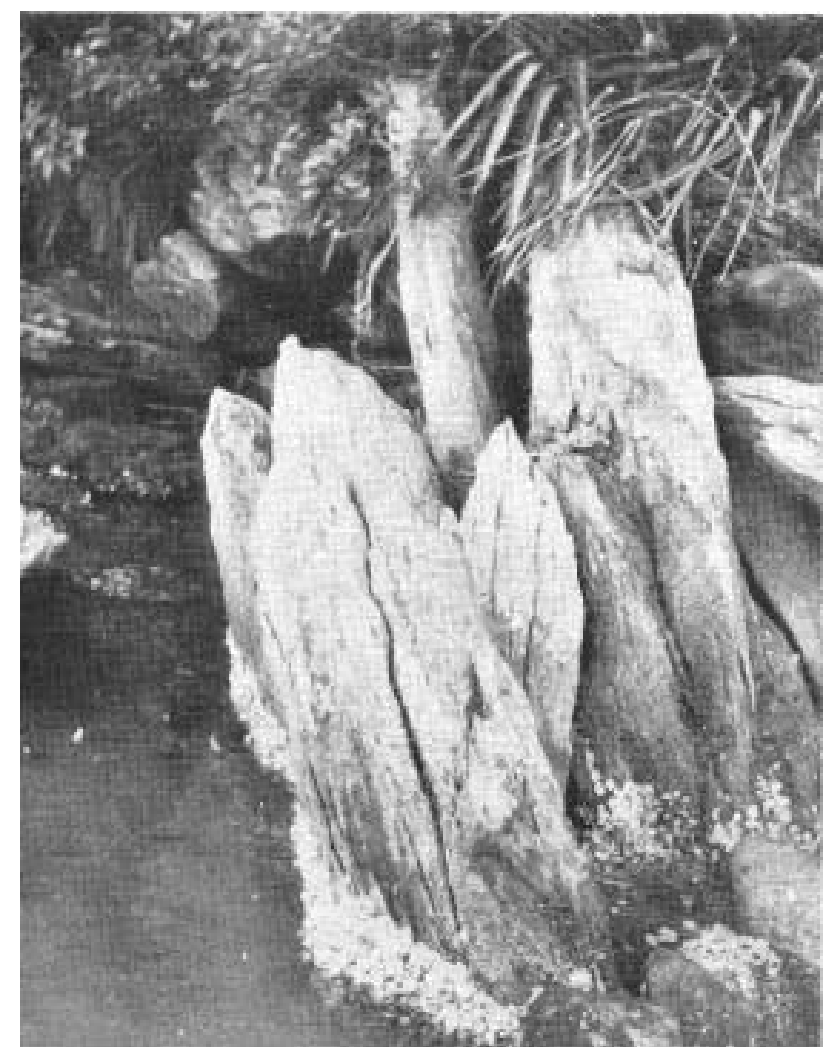

Fig. 70 - Algonquiano. Xistos gnaissificados da série Açunguí no lado norte da baia de Antonina, entre Ponta Talhada e Ponta Grossa, Paraná. Santa Catarina. 


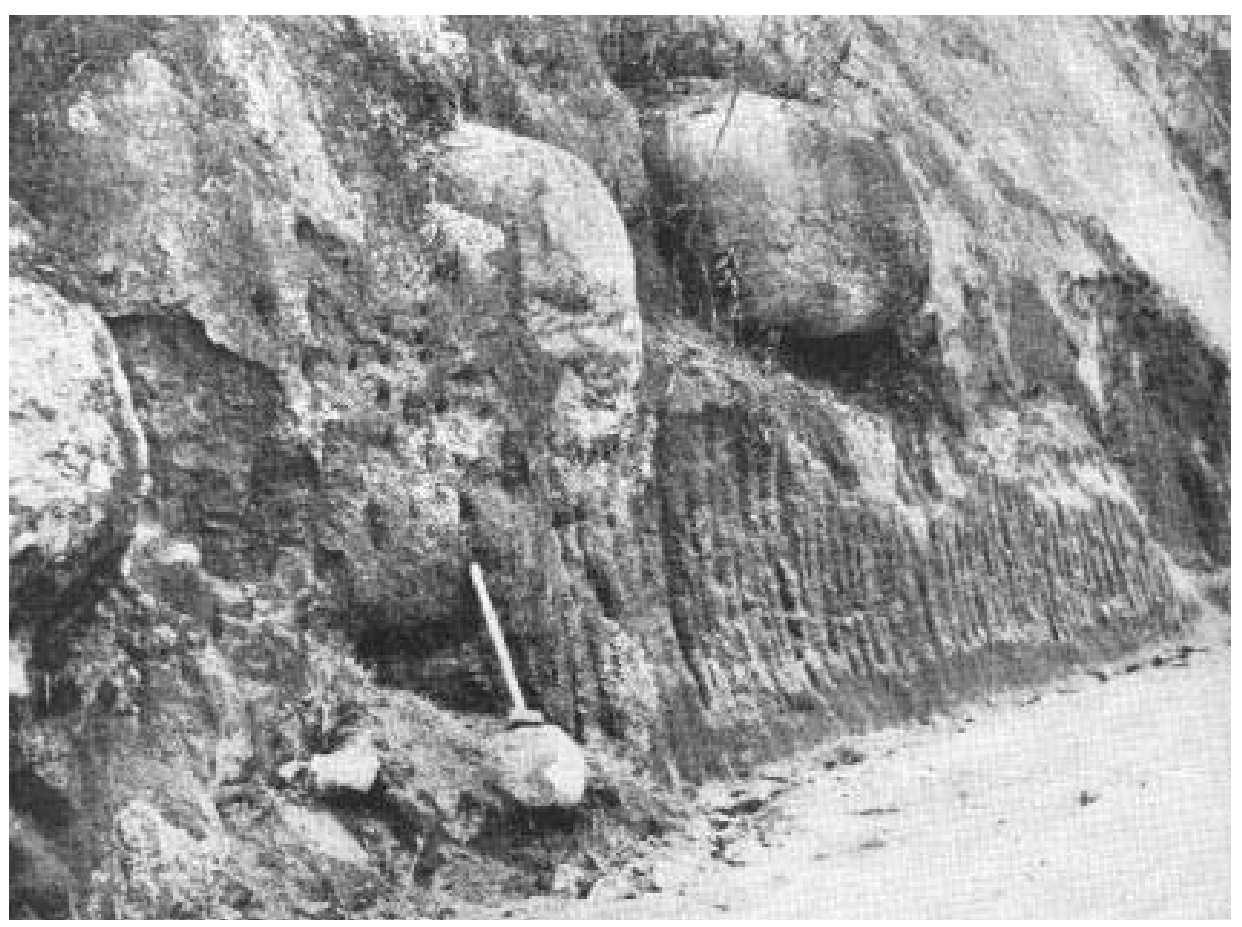

Fig. 71 - Algonquiano-huroniano. Blocos de granito post-algonquiano como núcleos mais resistentes na massa granítica, profundamente decomposta. Formas recentes de decomposição química motivada climaticamente. Região da série Açunguí, na estrada do Cerne. Primeiro planalto do Paraná. Santa Catarina.

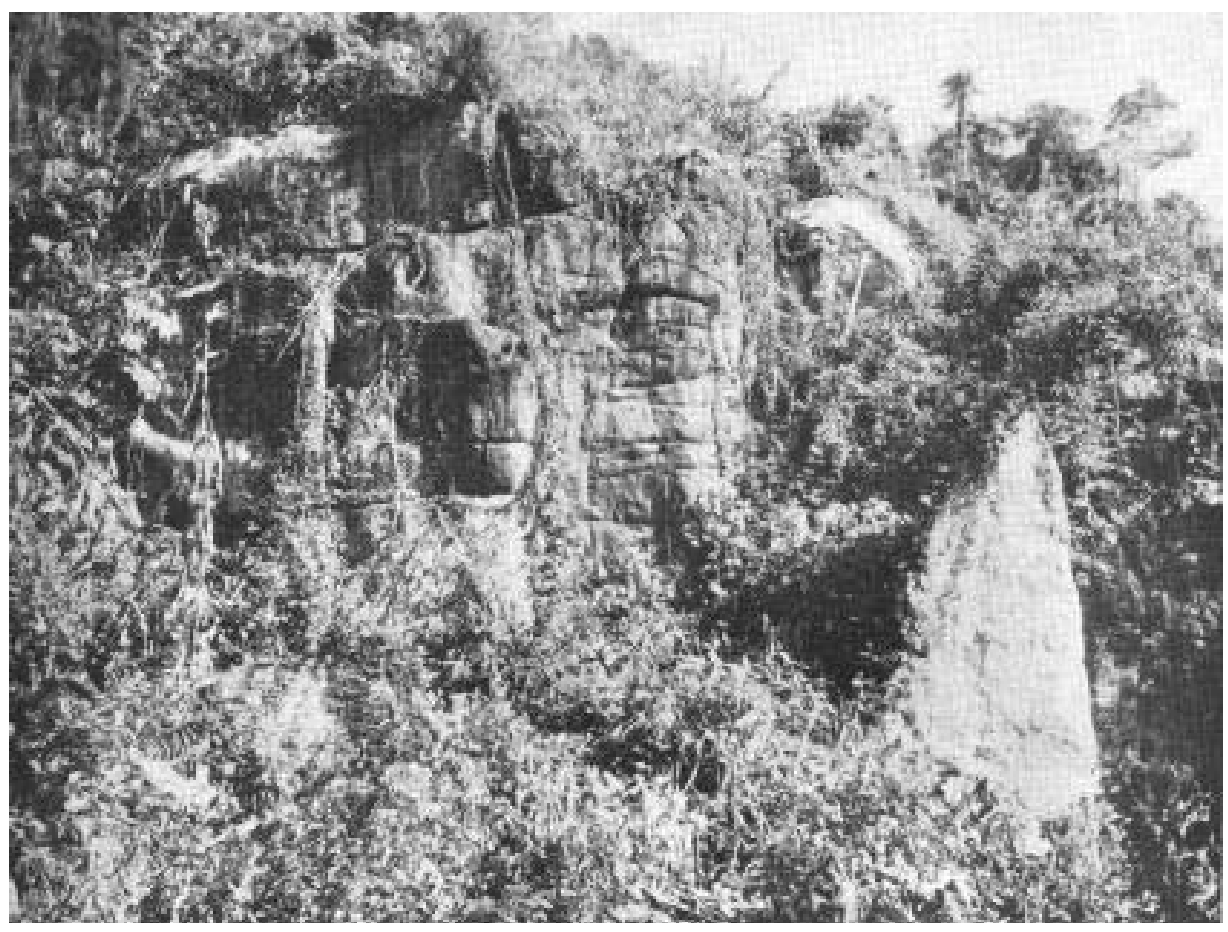

Fig. 72 - Algonquiano-huroniano. Paredão de granito-pórfiro, de granulação grossa, em Córrego Seco, no vale do rio Ribeira. Intrusão huroniana na série Açunguí do Paraná. Santa Catarina. 


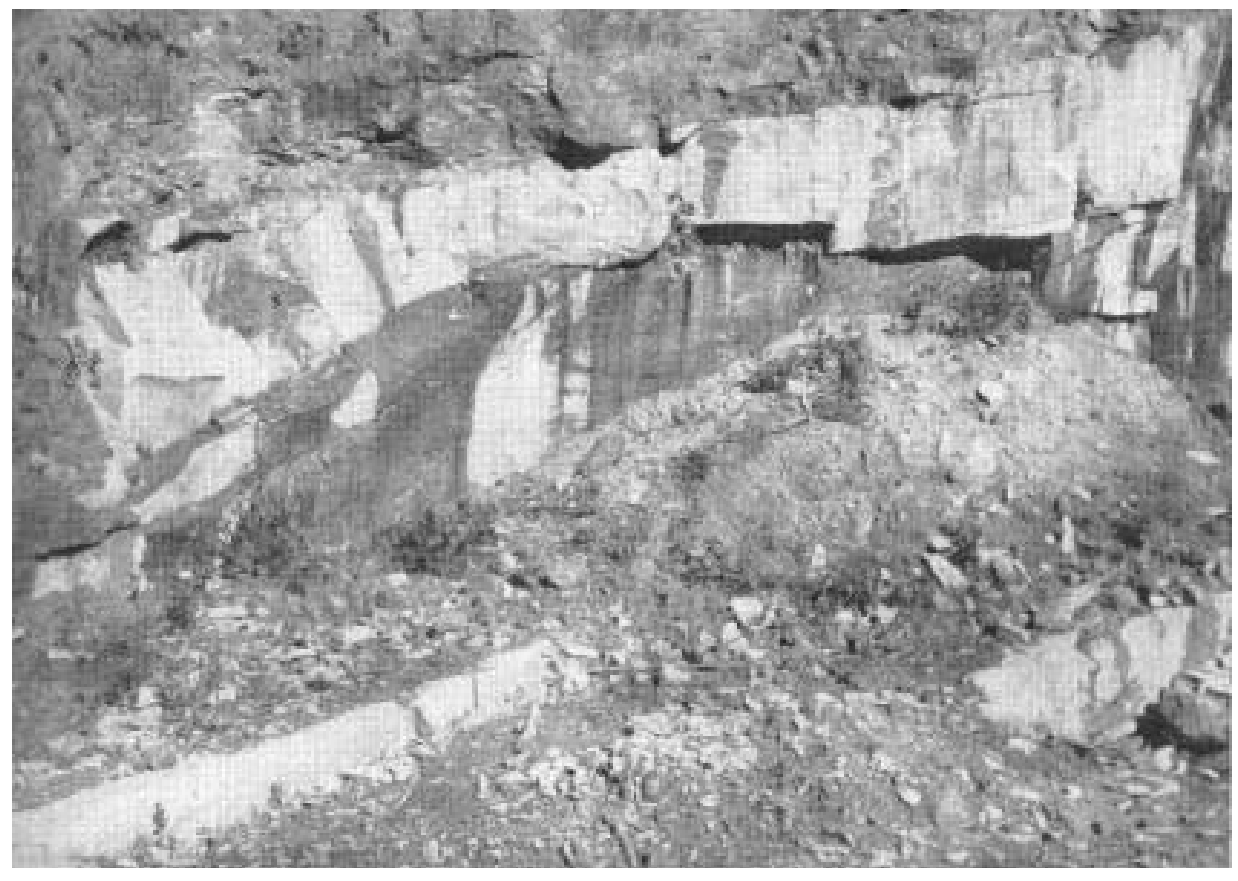

Fig. 73 - Algonquiano-huroniano. Granitos huronianos com estrutura de bancos (Lagen-Struktur) como núcleo anticlinal da série Brusque, na estrada Brusque-Nova Trento. Santa Catarina. 


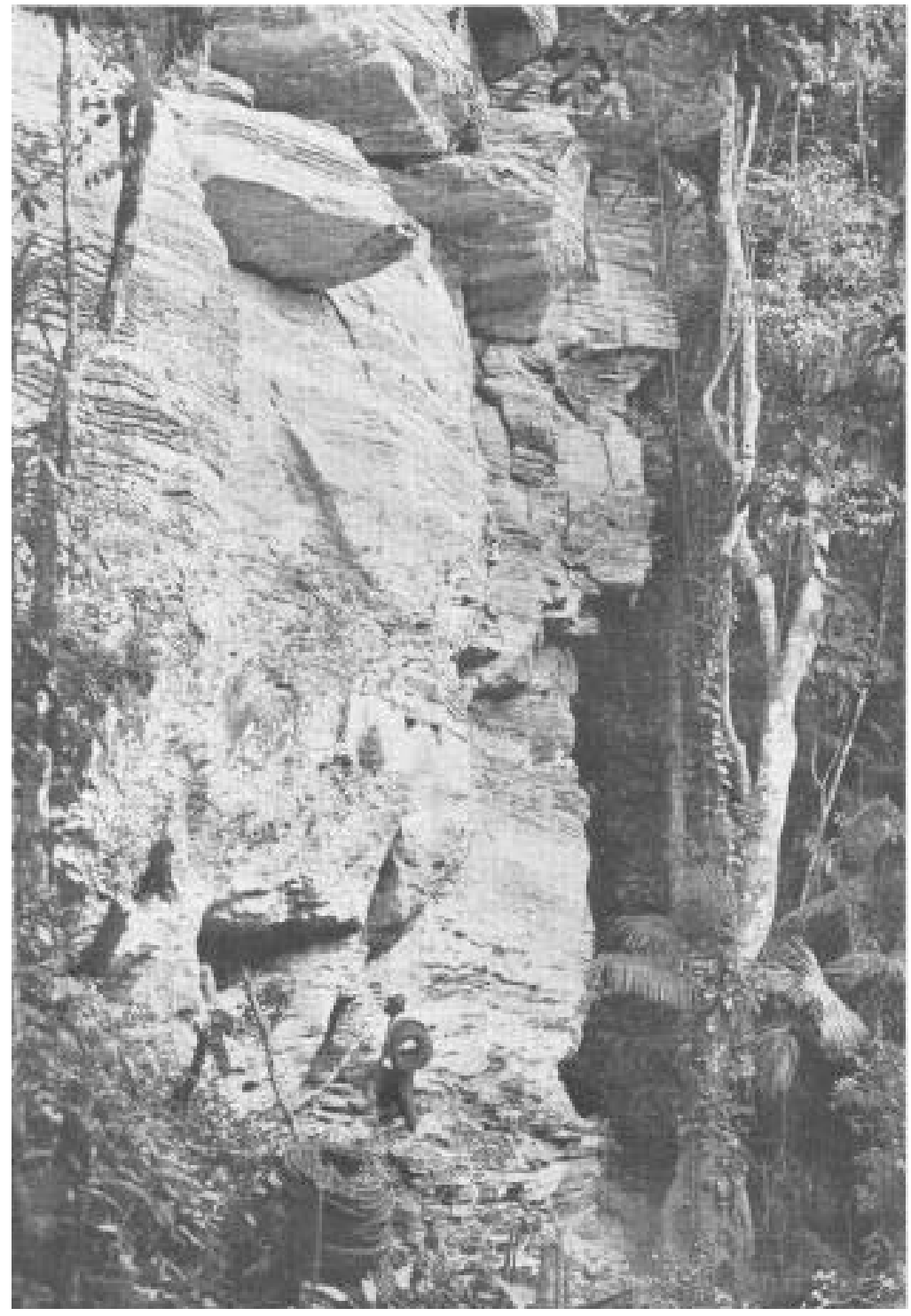

Fig. 74 - Algonquiano. Camadas calcáreas da série Açunguí no vale do rio Guaraqueçaba. O morro das Ossadas em Barro Branco, litoral do Paraná. Santa Catarina. 


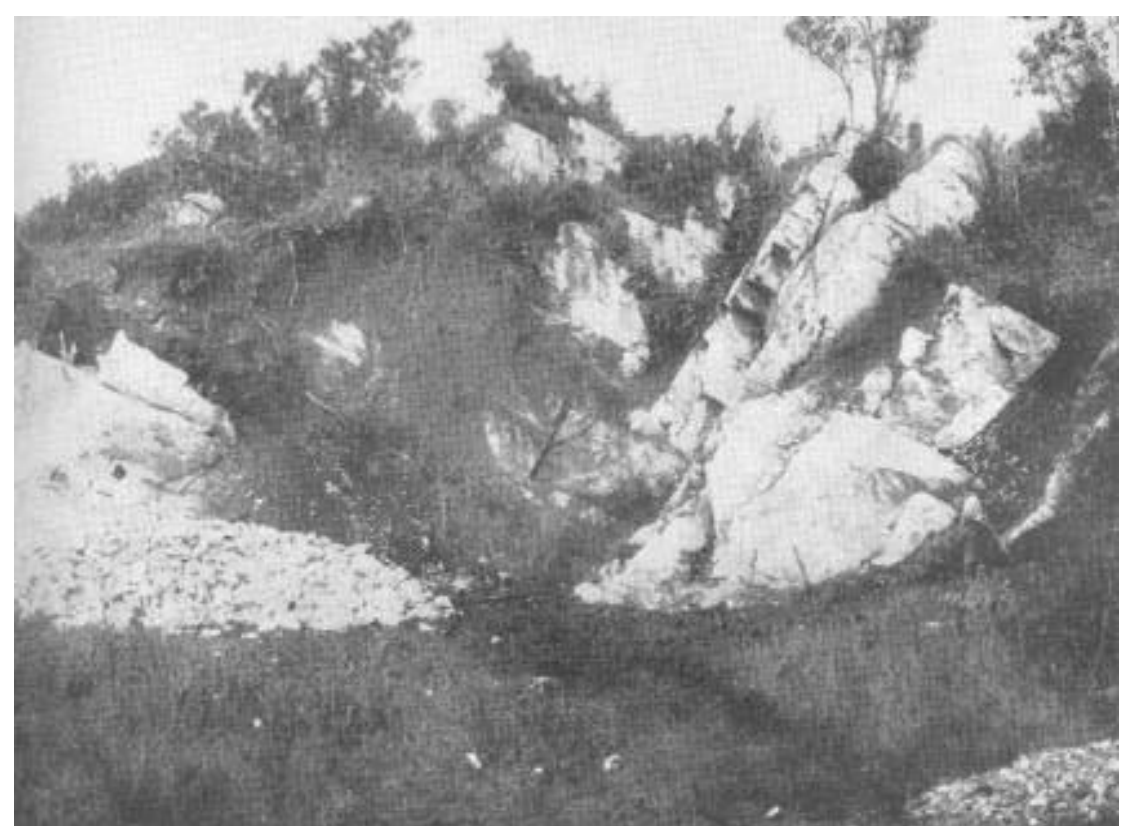

Fig. 75 - Algonquiano. Calcáreos brancos da série Açunguí em Tranqueira. Primeiro planalto do Paraná. Santa Catarina.

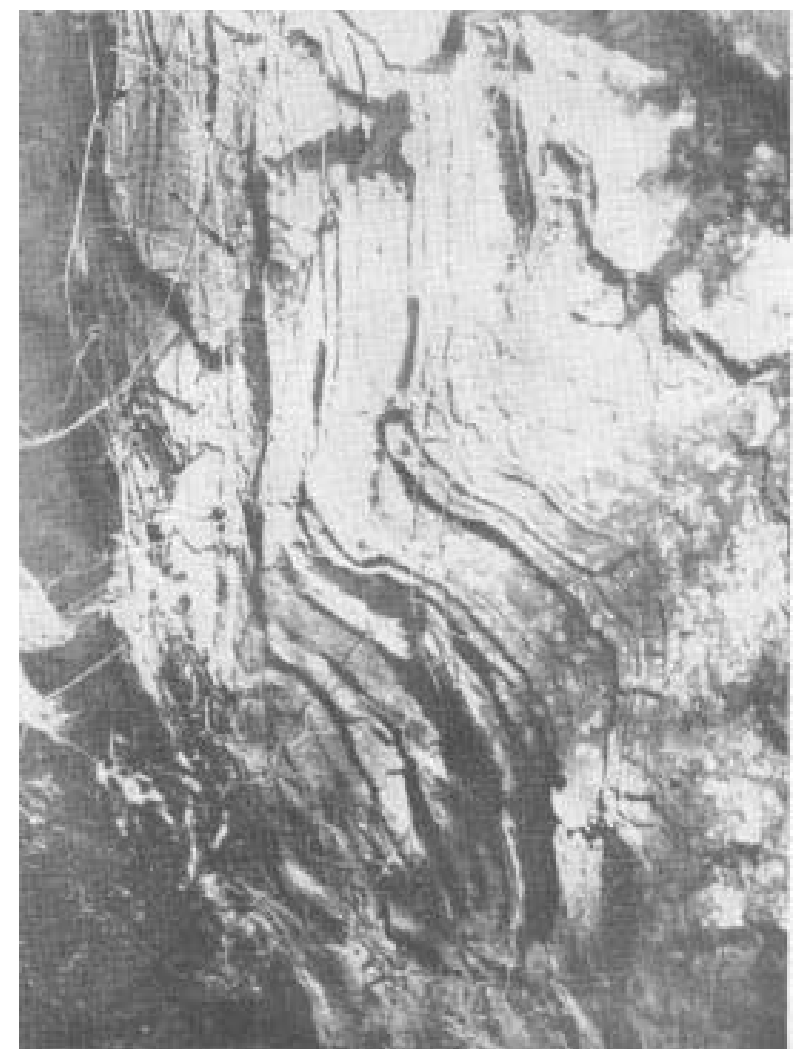

Fig. 76 - Algonquiano. Filitos calcáreos da série Açunguí, abruptamente erguidos e finalmente dobrados, entre Córrego Seco e a barra do ribeirão do Rocha, no vale do rio Ribeira - Paraná. Santa Catarina. 


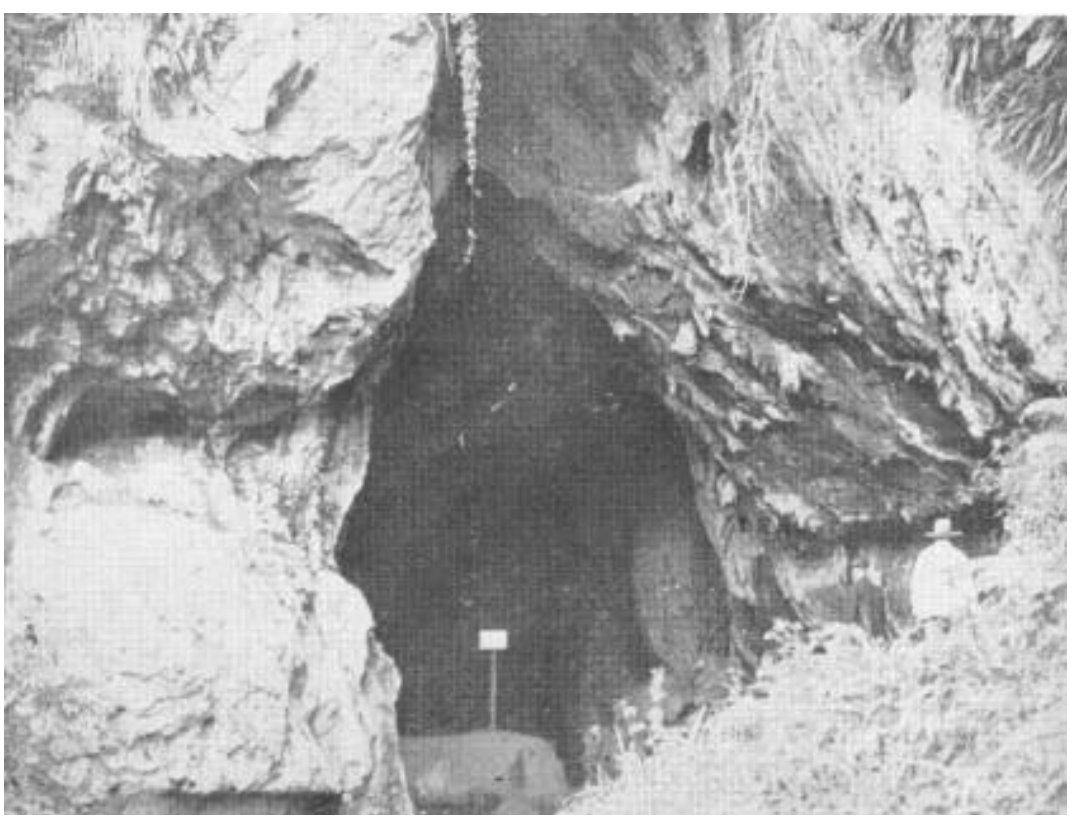

Fig. 77 - Algonquiano. Entrada de uma gruta nos calcáreos da série Açunguí em Campinhos, primeiro planalto do Paraná. Santa Catarina.

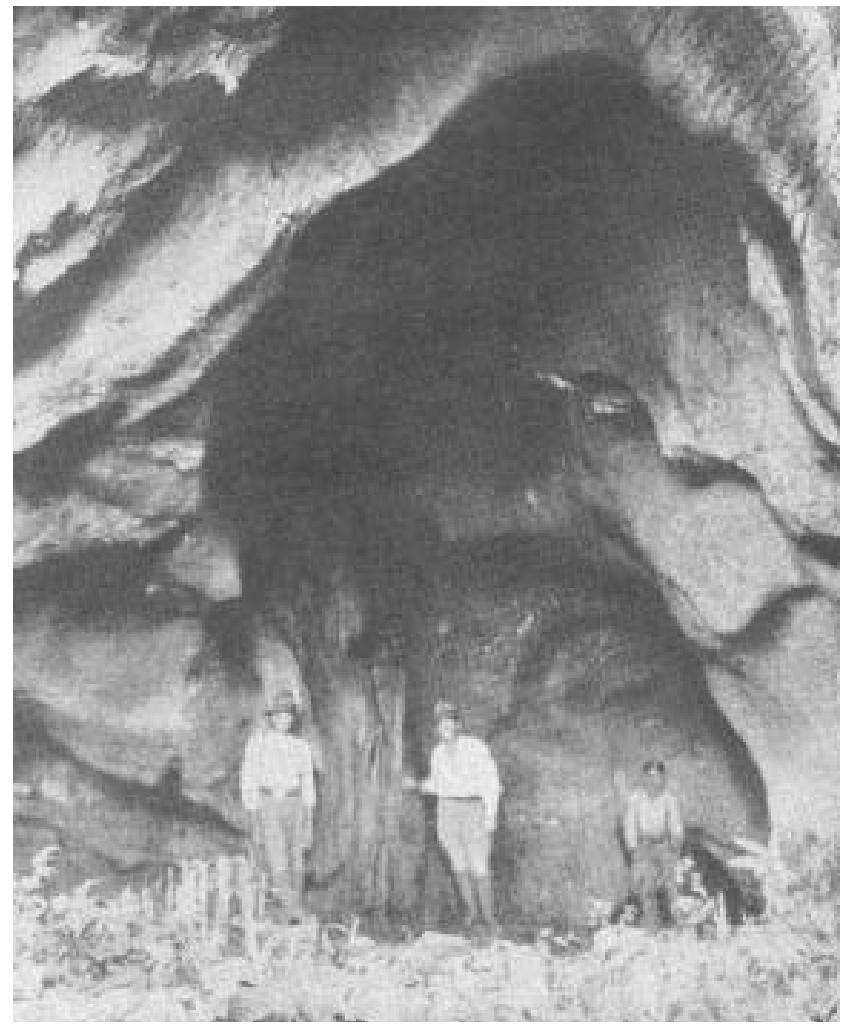

Fig. 78 - Algonquiano. Entrada de uma gruta calcárea na série Brusque em Várzea Grande, no vale do ribeirão d'Ouro. Itajaí-Mirim. Santa Catarina. 


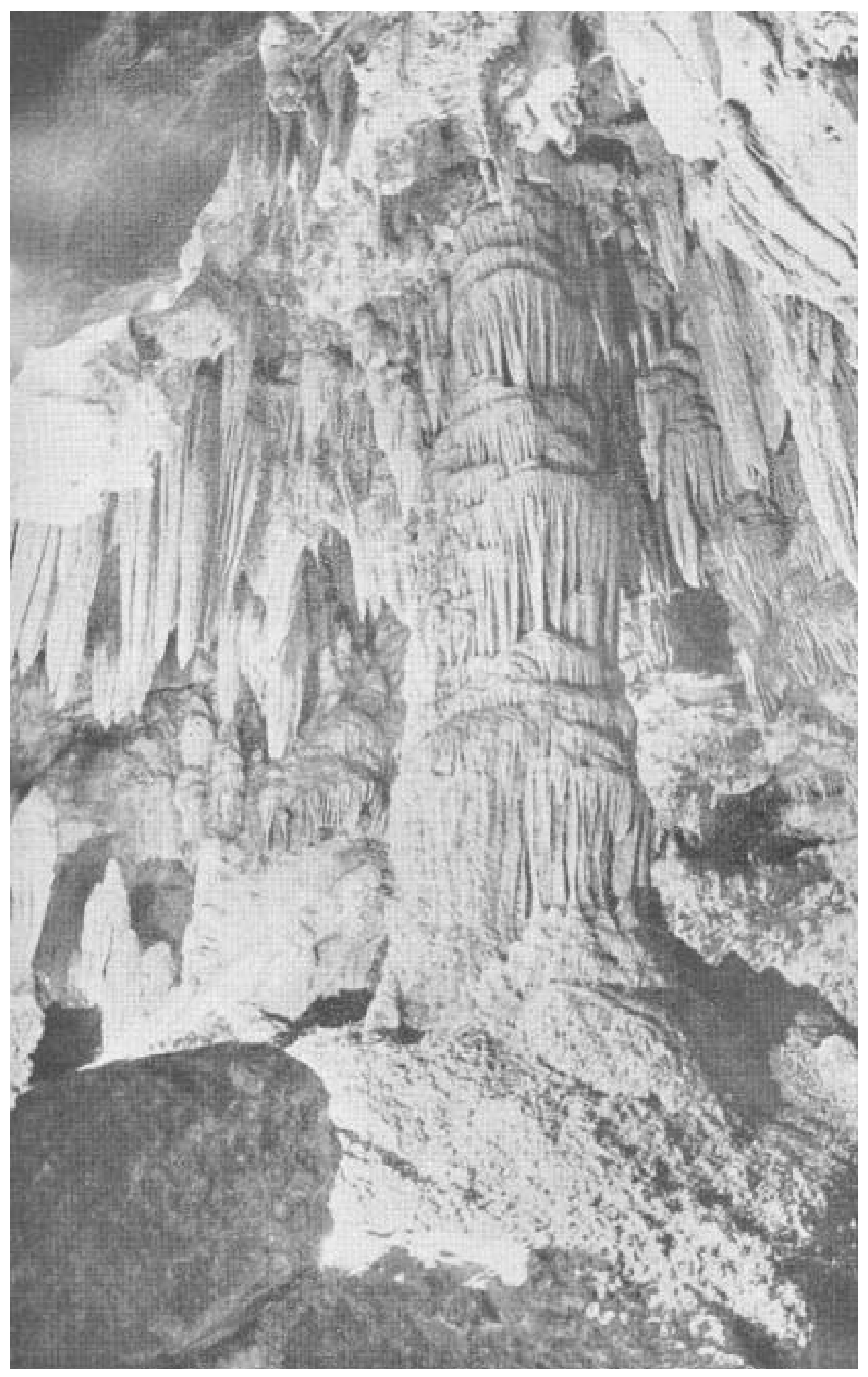

Fig. 79 - Algonquiano. Vista parcial do interior da gruta de Campinhos, perto da estrada Curitiba-Paranaí, primeiro planalto do Paraná. 


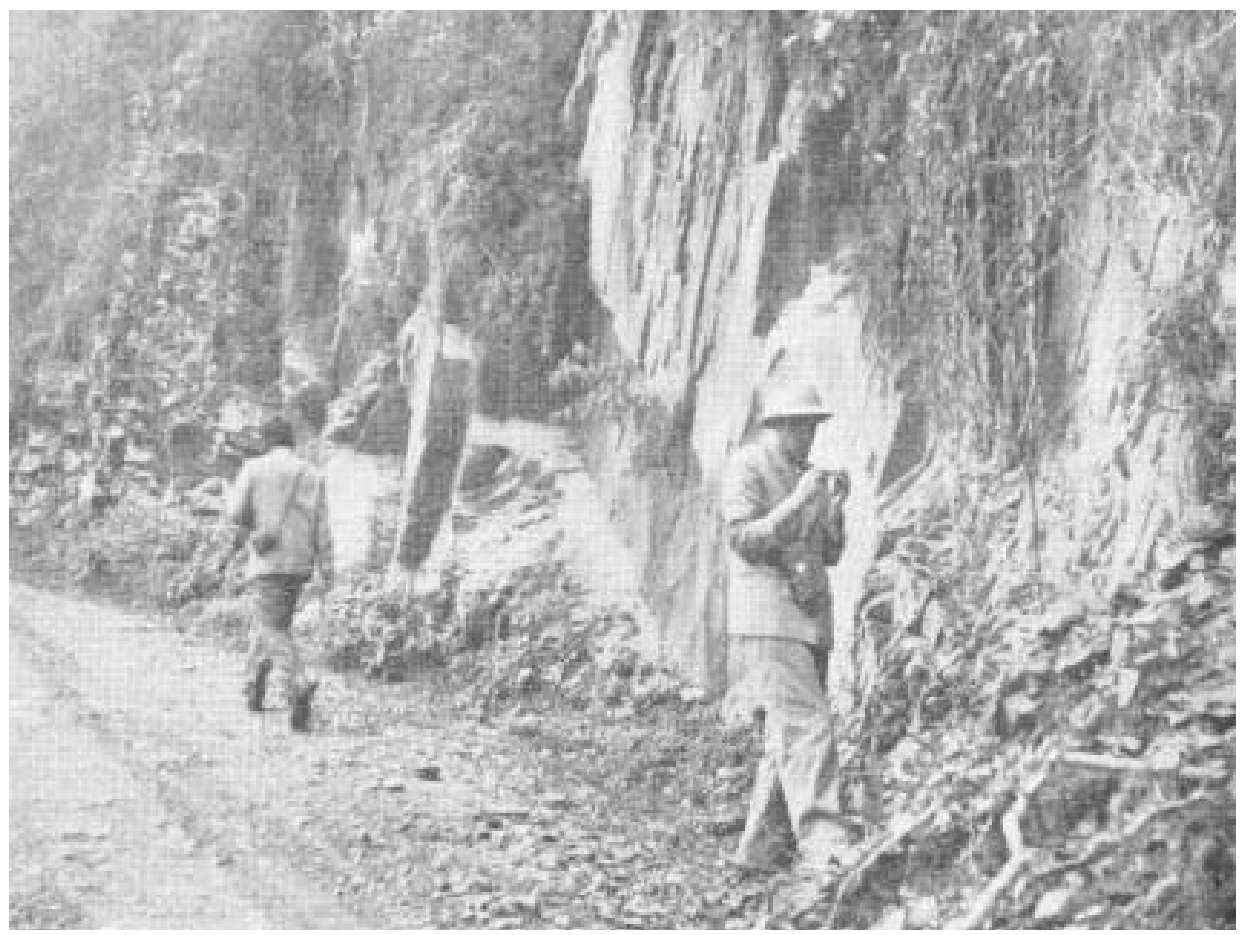

Fig. 80 - Ordoviciano. Ardósios escuros, duros, erguidos quase verticalmente; afloramentos da série Itajaí em Subida, vale do rio Itajaí-Açú, Santa Catarina.

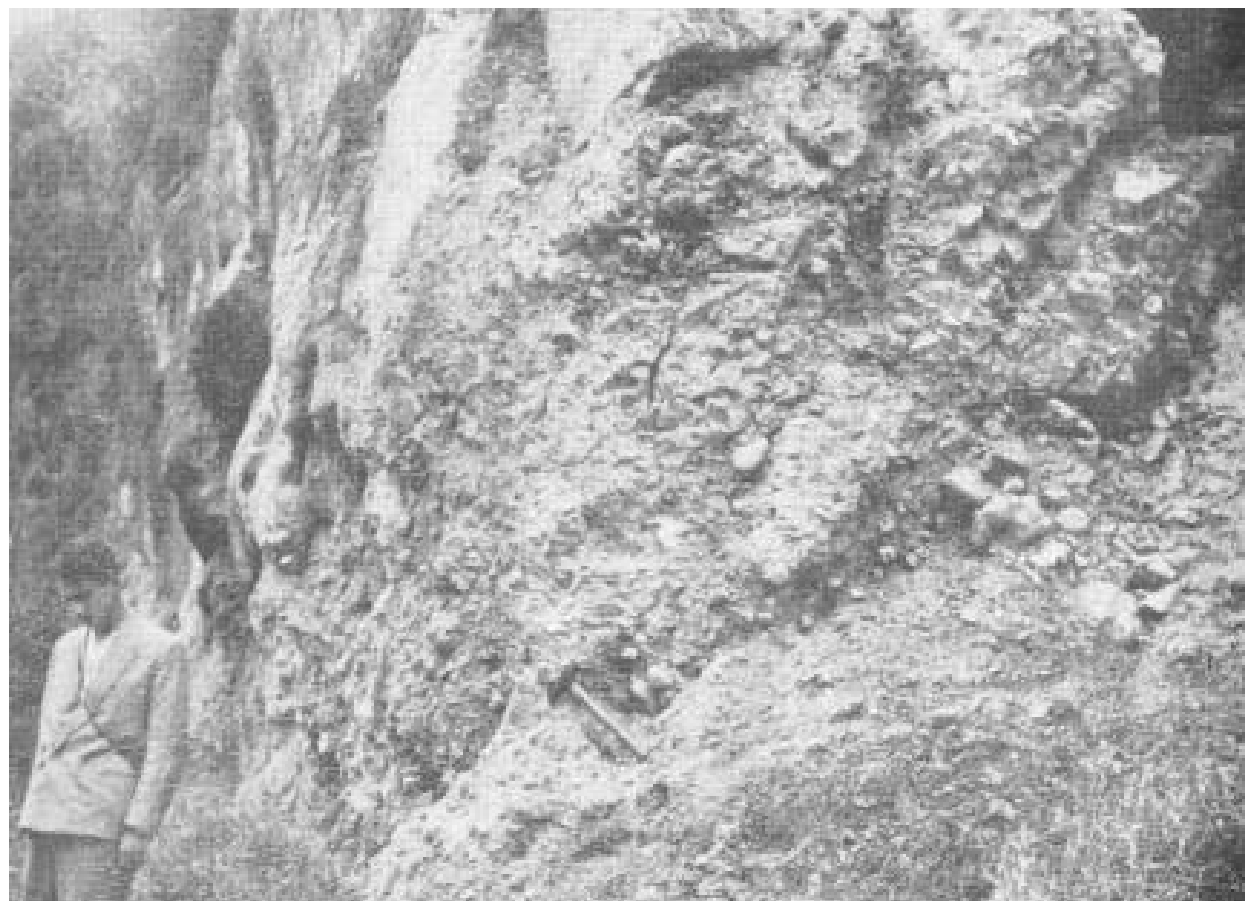

Fig. 81 - Ordoviciano. Conglomerados da série Itajaí em Ascurra, vale do rio Itajaí-Açú, Santa Catarina. 


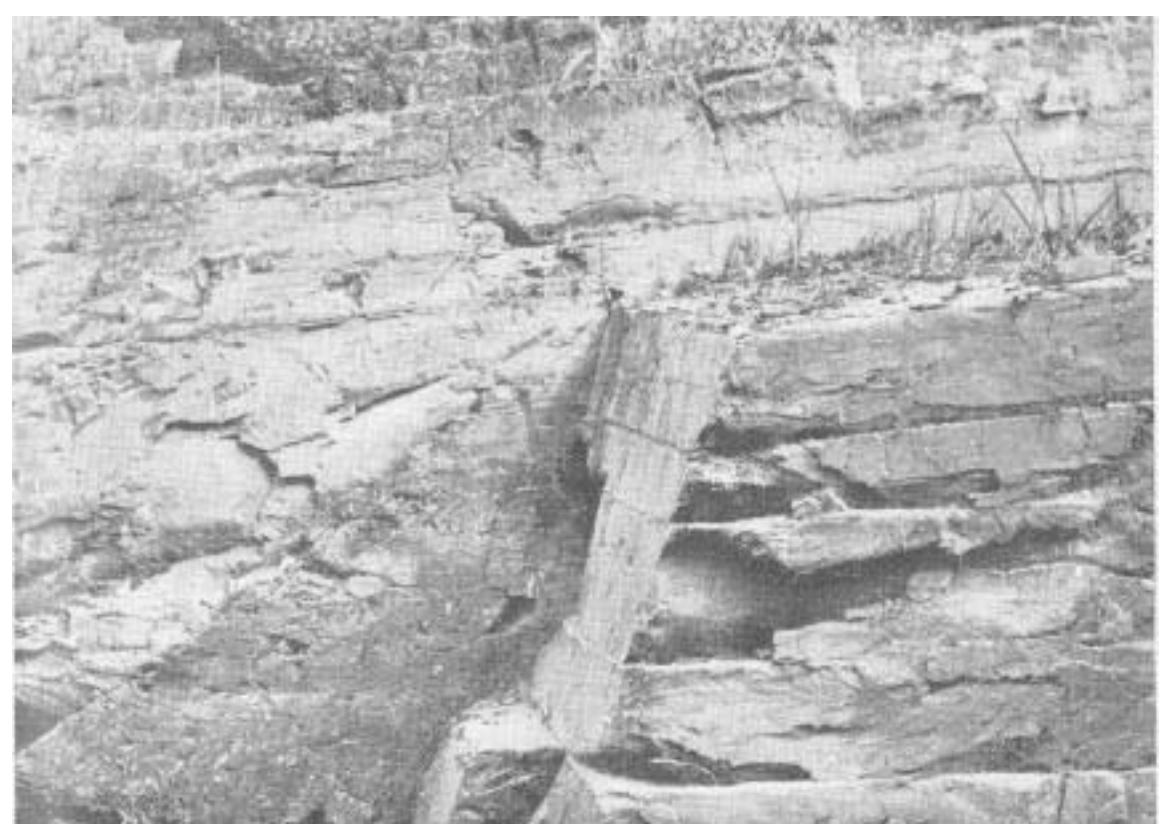

Fig. 82 - Ordoviciano. Bancos areno-argilosos, vermelhos, da série Itajaí, jazendo quase horizontalmente. Afloramento entre Blumenau e Gaspar, vale do rio Itajaí-Açú, Santa Catarina.

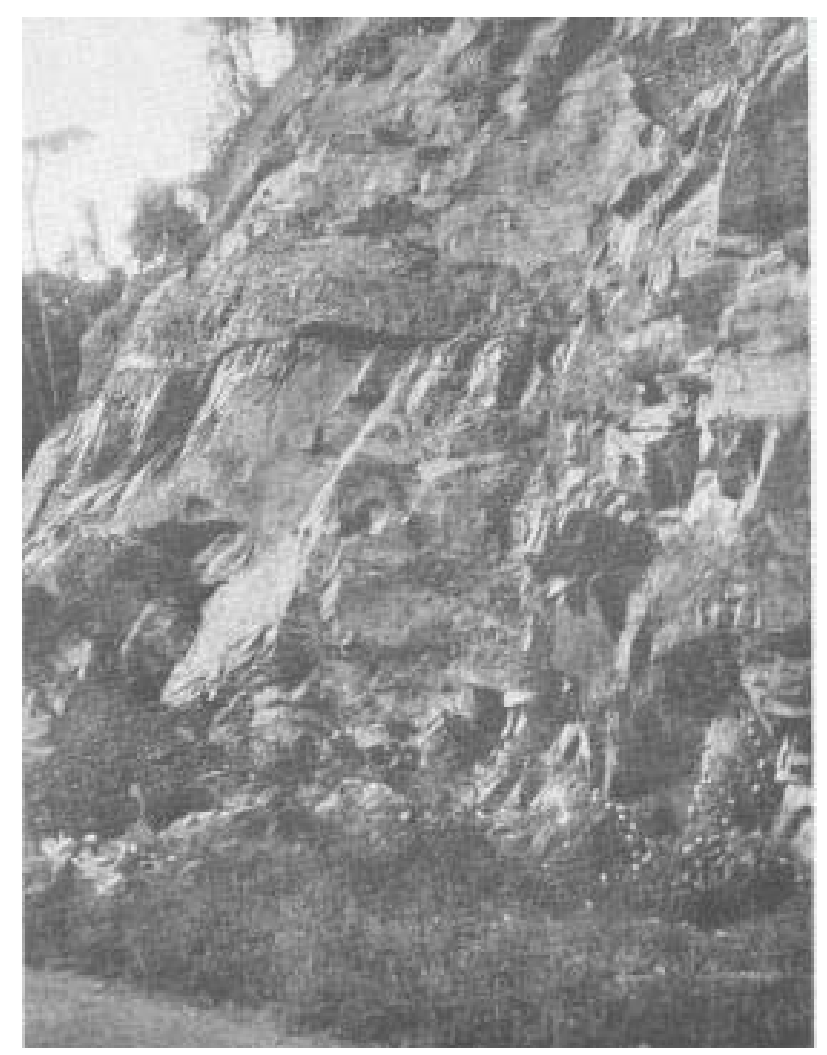

Fig. 83 - Ordoviciano. Arenitos da série Itajaí, roxo-avermelhados, levemente inclinados para W. Blumenau, Santa Catarina. 


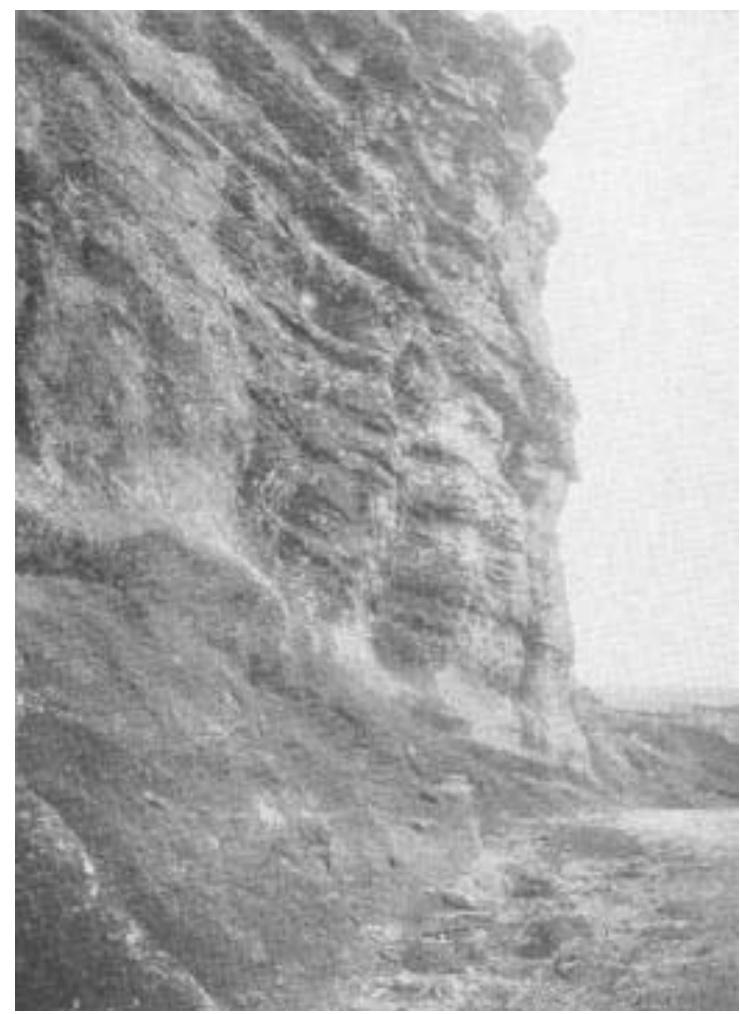

Fig. 84 - Siluriano e devoniano. Paredão do arenito das Furnas com depósitos prédevonianos de drift glacial na base. Serra São Joaquim, escarpa devoniana, Paraná.

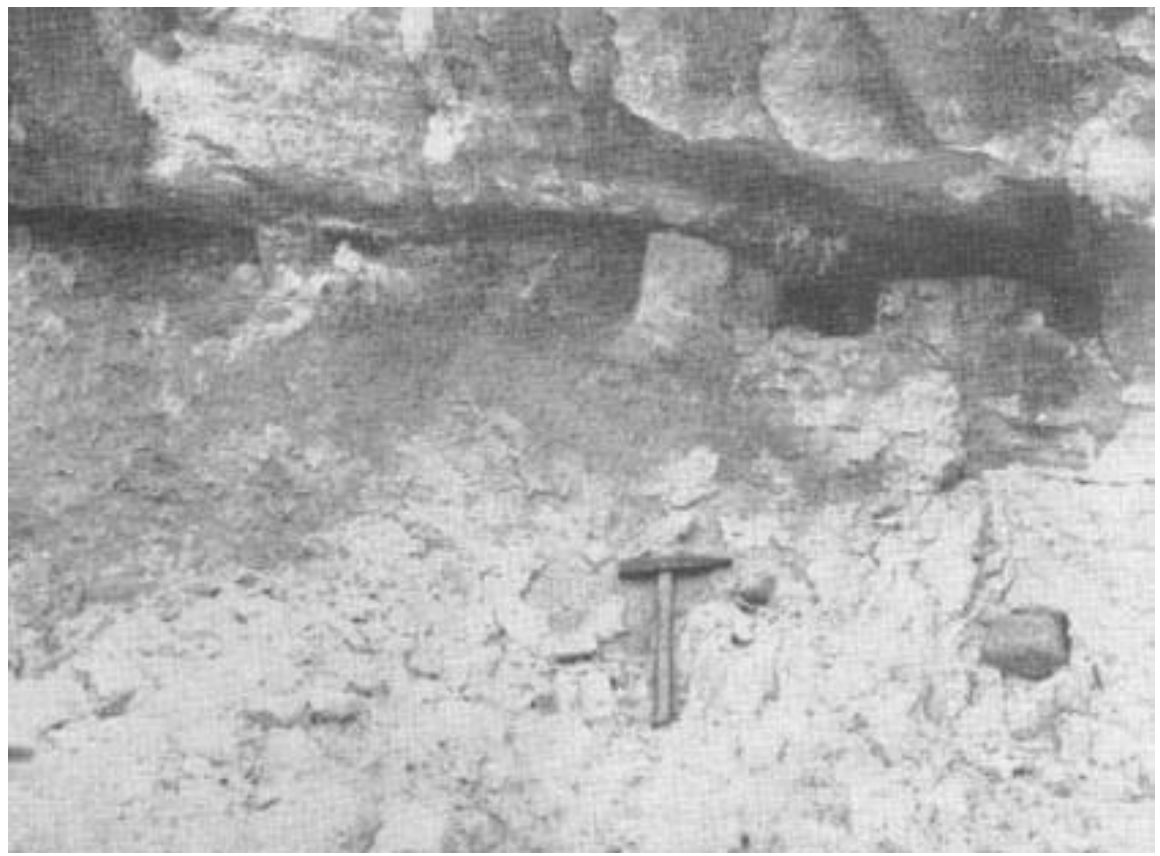

Fig. 85 - Siluriano - Gotlandiano. Depósitos pré-devonianos de drift glacial na base do arenito das Furnas, na Serra São Joaquim, entre 1123 e 1135 m s.n.m. Escarpa devoniana, Paraná. 


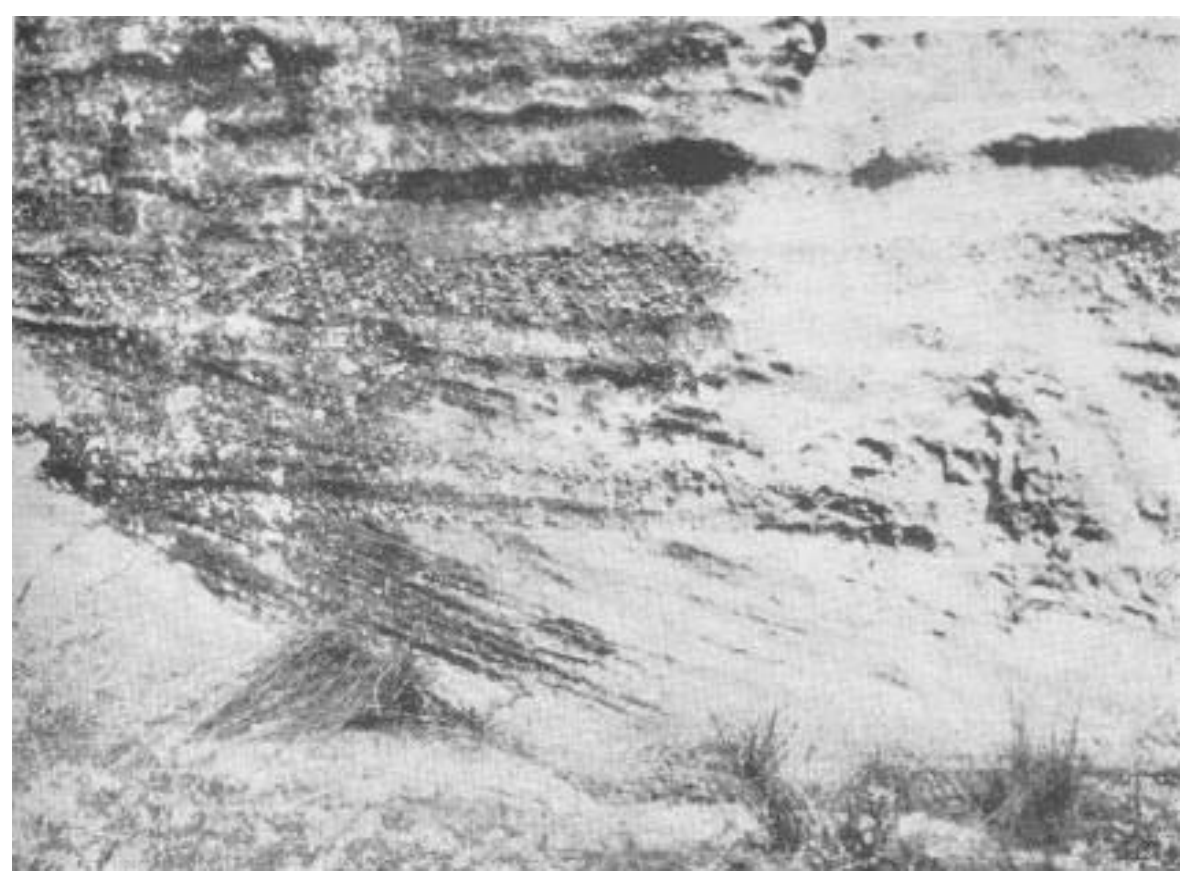

Fig. 86 - Devoniano inferior. Estratificação discordante-diagonal do arenito das oeste de Castro, Paraná.

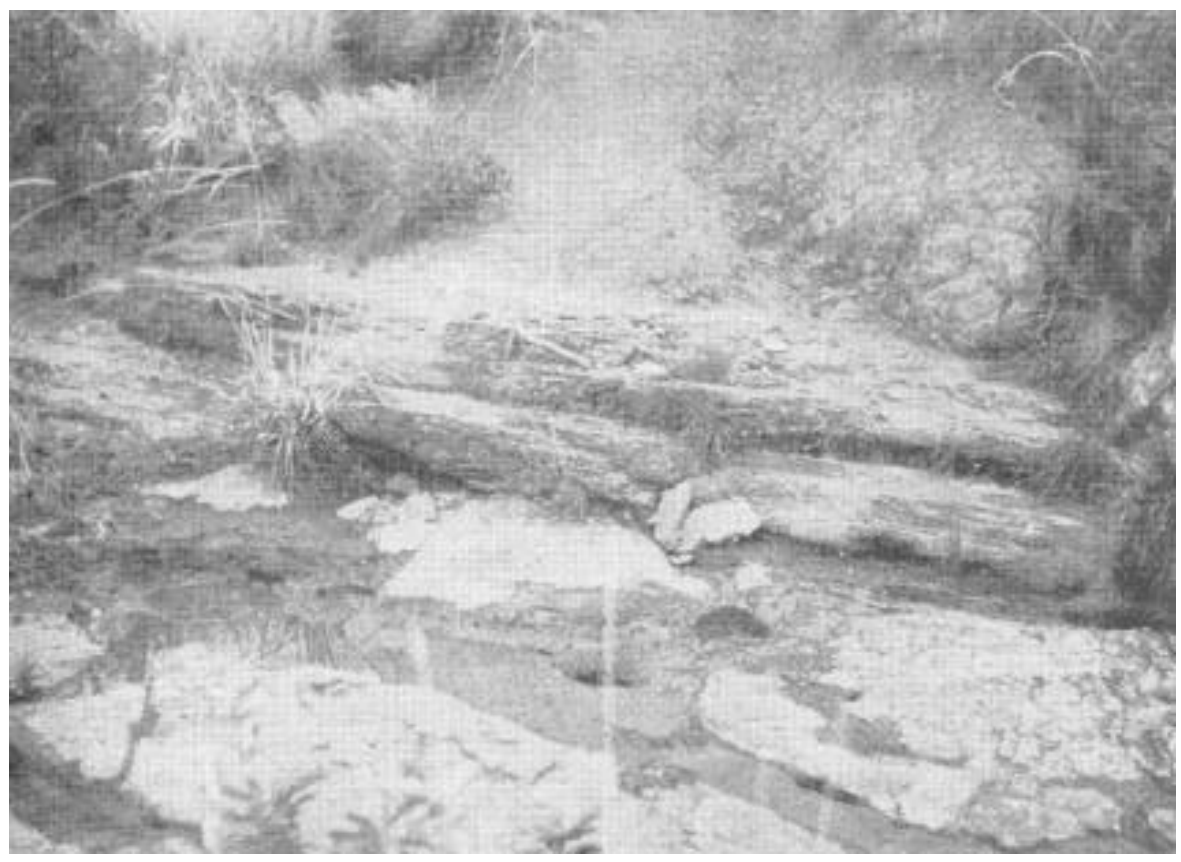

Fig. 87 - Devoniano inferior. Afloramento dos folhelhos de Ponta Grossa na base Paraná (963 m s.n.m.) 


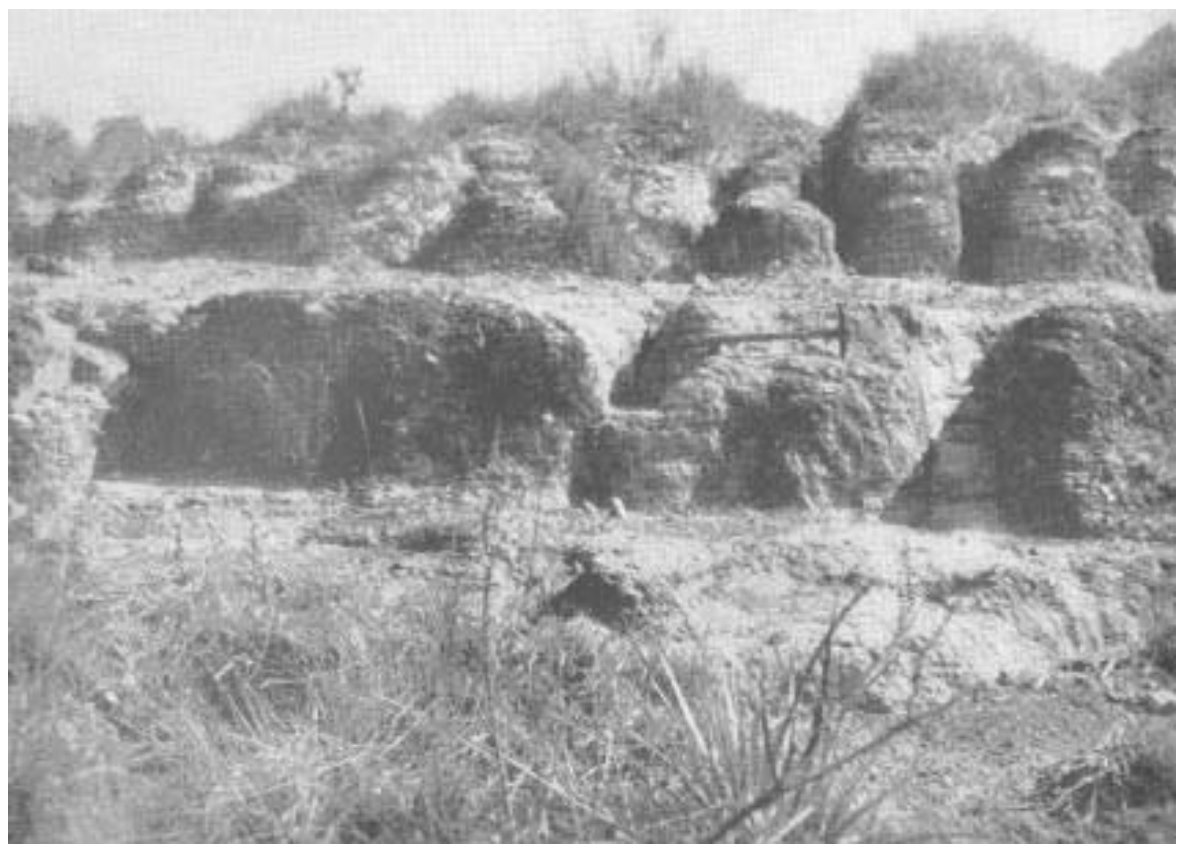

Fig. 88 - Devoniano inferior. Bancos do arenito Tibagí no vale do rio São Domingos de Baixo, a oeste de Tibagí, na cota de $764 \mathrm{~m}$. Camadas ricas em Spirifer. Segundo planalto do Paraná.

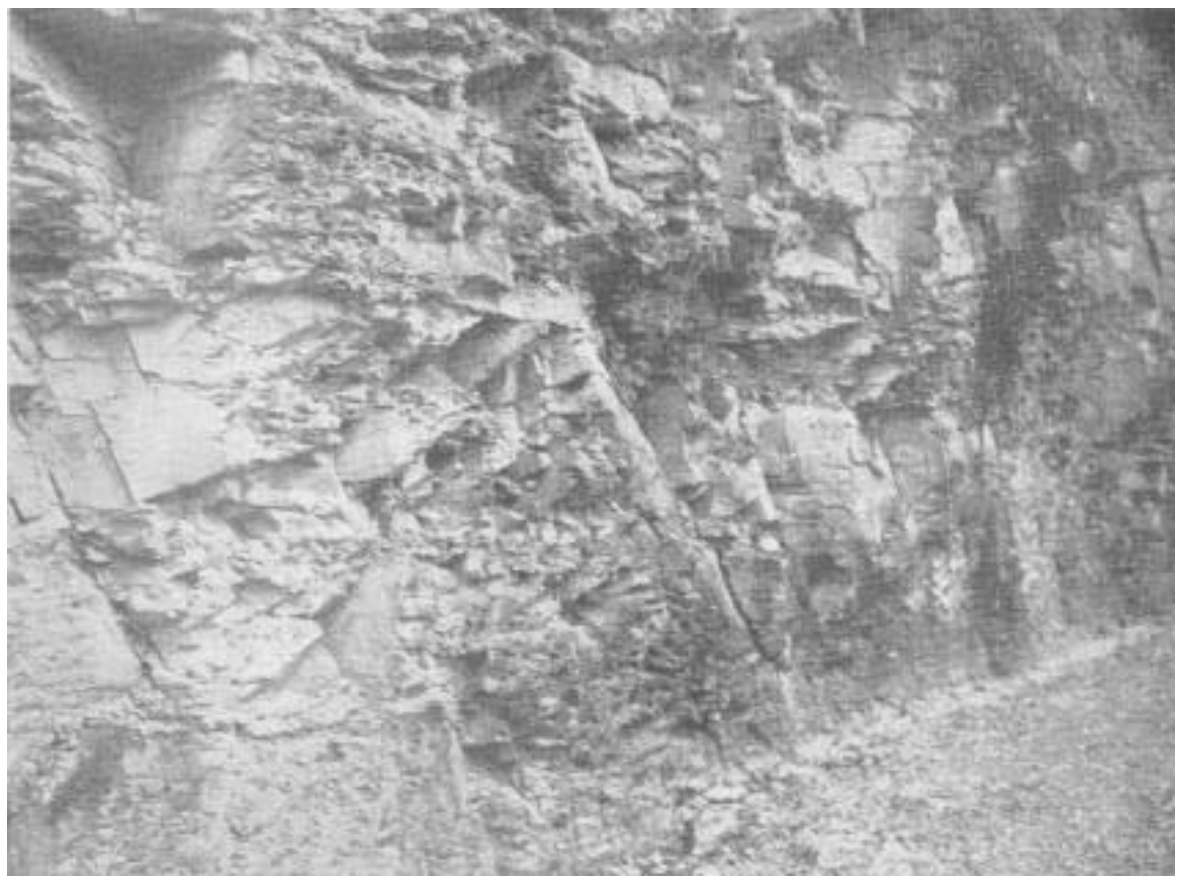

Fig. 89 - Devoniano inferior. Folhelhos de São Domingos (grupo Santa Rosa) em Lambedor (830 m s.n.m.). Segundo planalto do Paraná. 


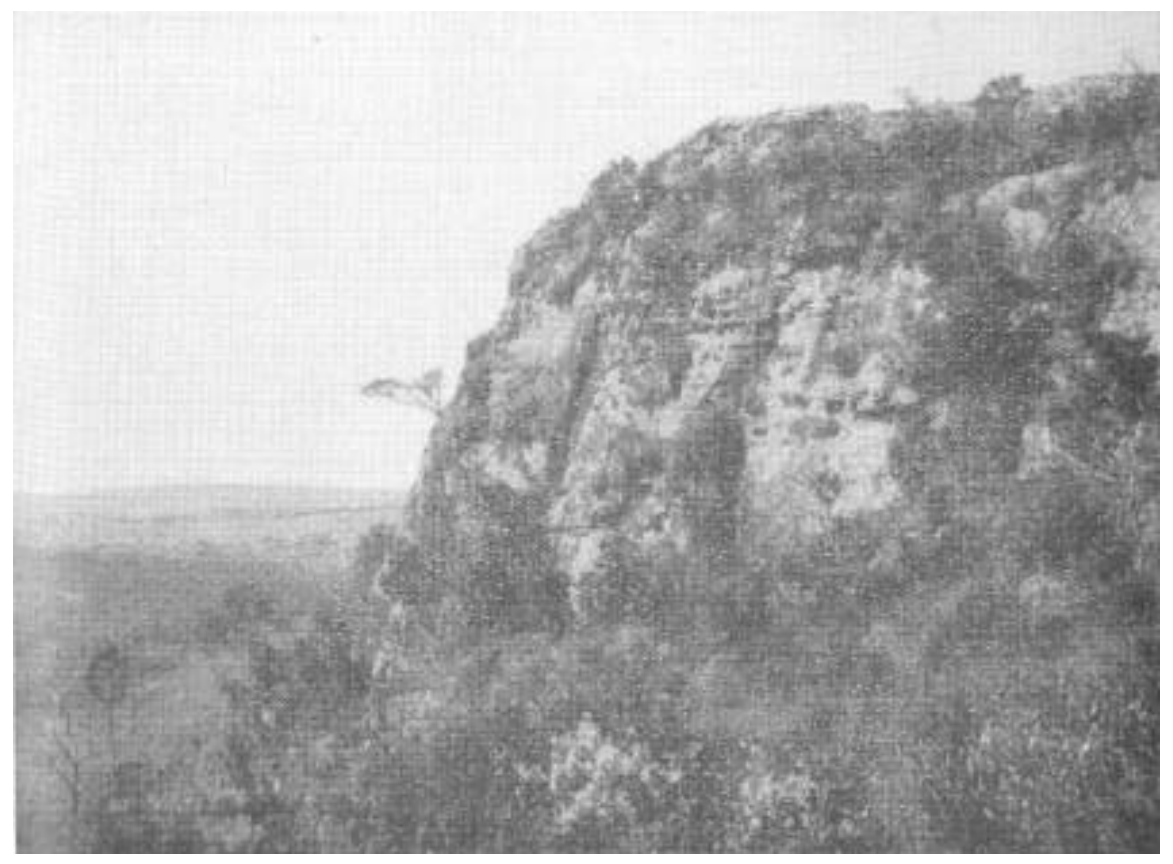

Fig. 90 - Devoniano inferior. Arenitos de Barreiro na Serra do Barreiro, a oeste de Tibagí, entre 850 e 1025 m s.n.m. Segundo planalto do Paraná.

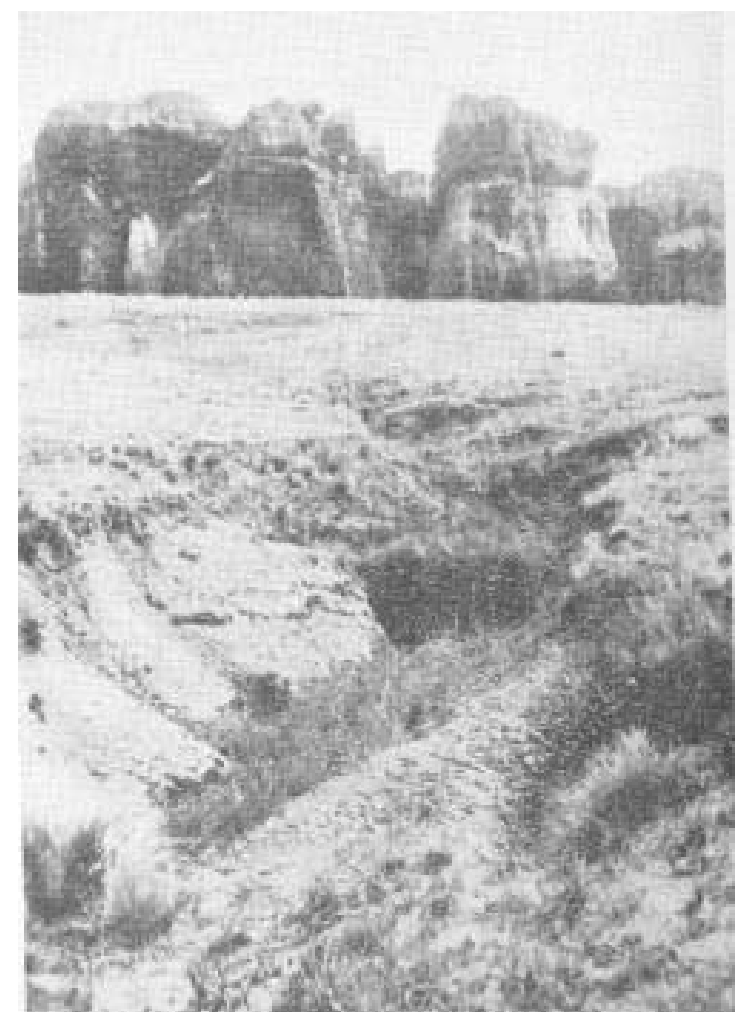

Fig. 91 - Carbonífero superior. Grupo Itararé da série Tubarão. Camadas de varvitos avermelhados na base do arenito flúvio-glacial de Vila Velha nos Campos Gerais de ponta Grossa. Segundo planalto do Paraná. 


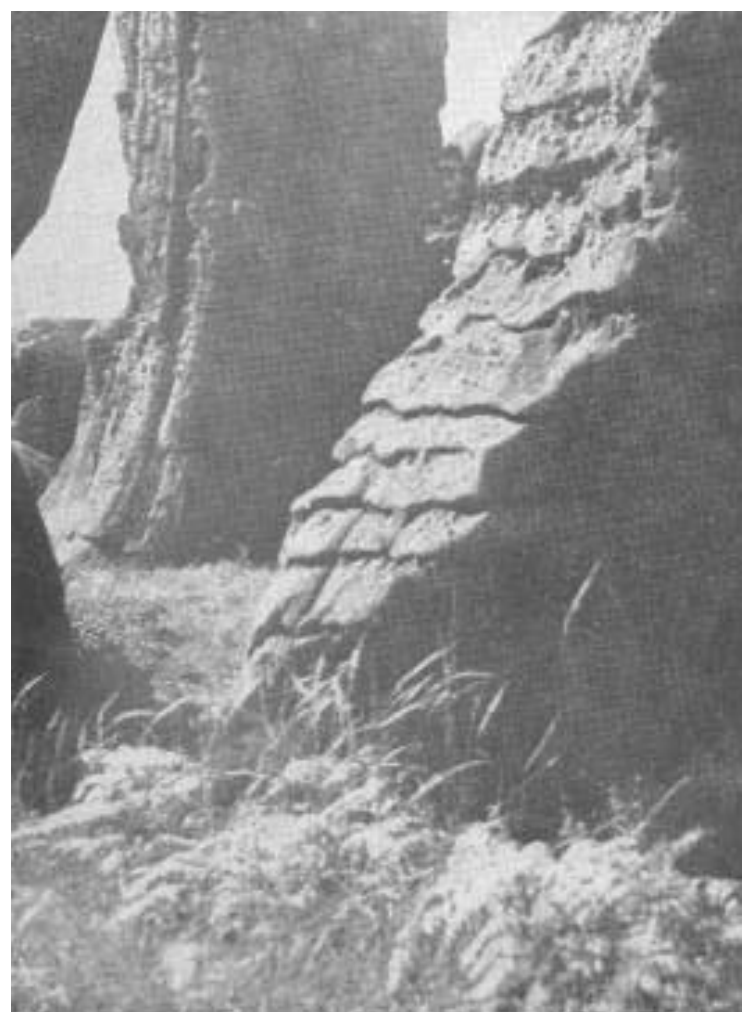

Fig. 92 - Carbonífero superior. Grupo Itararé da série Tubarão. Decomposição escamosa (estrutura imbricada) nos paredões do arenito flúvio-glacial de

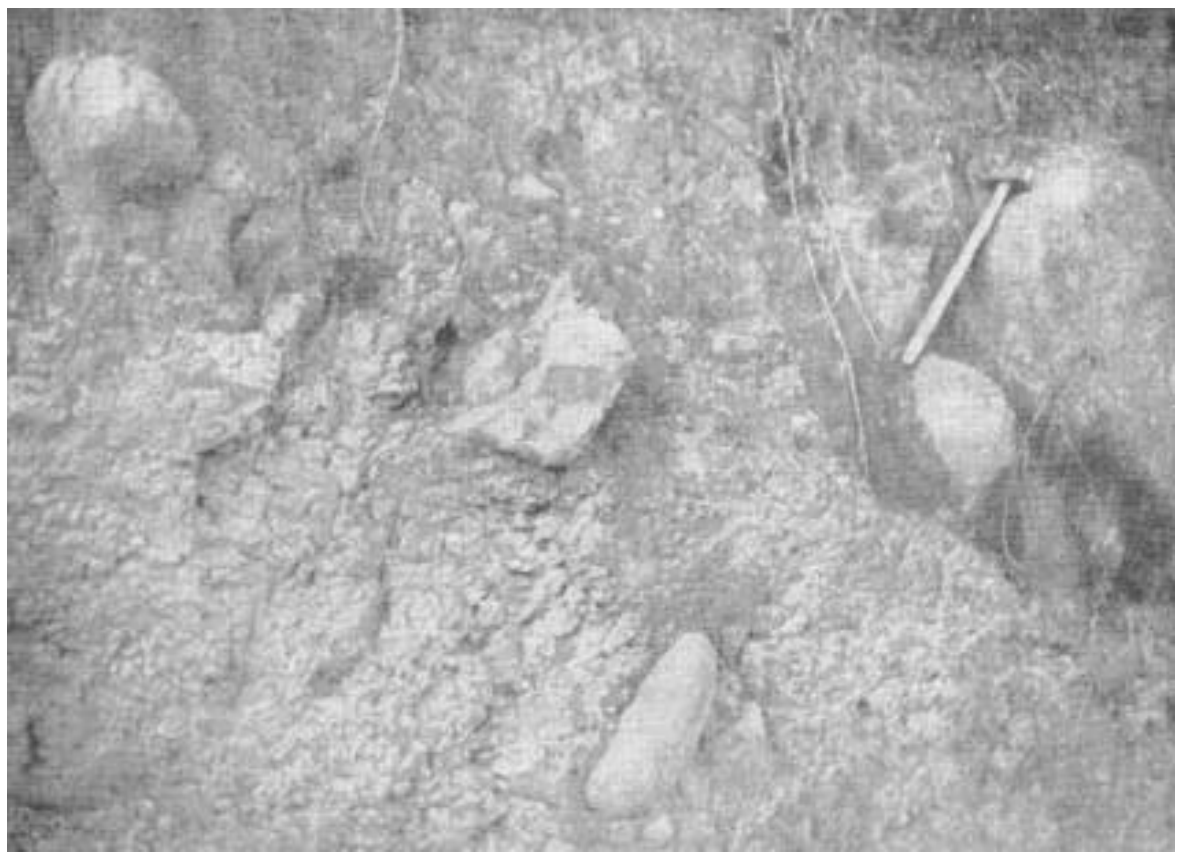

Fig. 93 - Carbonífero superior. Fácies continental-glacial do grupo Itararé. Tilito no km 217 da estrada do Cerne, a oeste de Ventania. Segundo planalto 


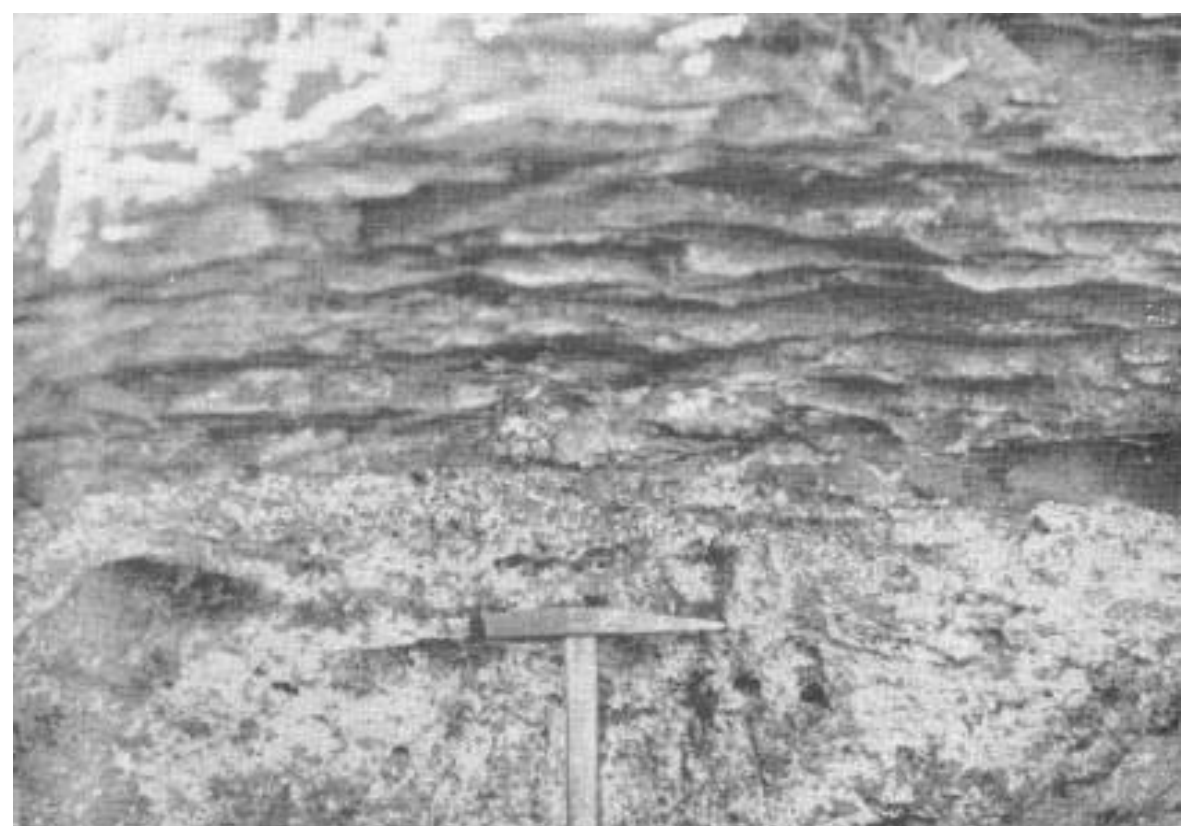

Fig. 94 - Carbonífero superior. Contacto das camadas glaciais do grupo Itararé com os granitos do complexo cristalino, no litoral de Santa Catarina,

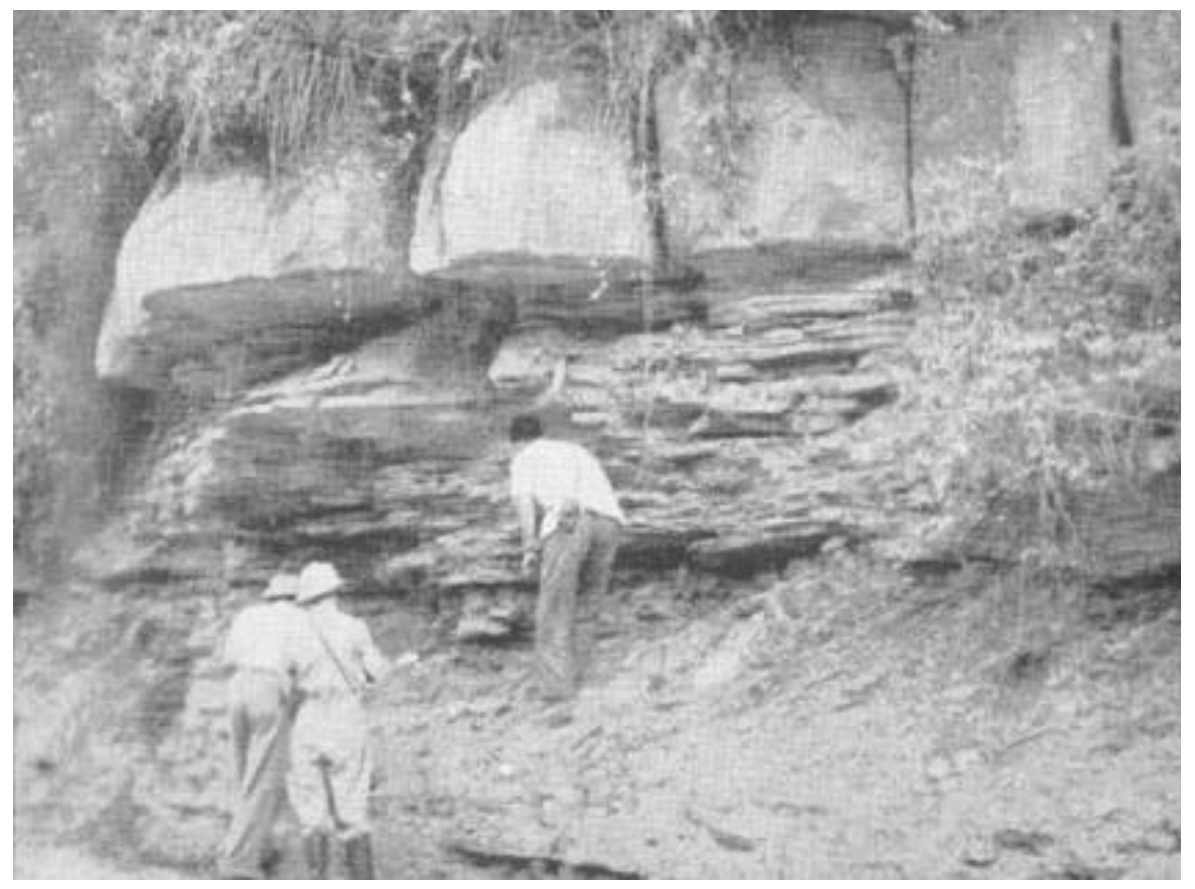

Fig. 95 - Carbonífero superior. Grupo Itararé da série Tubarão. Arenitos flúvioglaciais sobre varvitos escuros, entre os km 106 e 108 da estrada

Geral. Santa Catarina. 


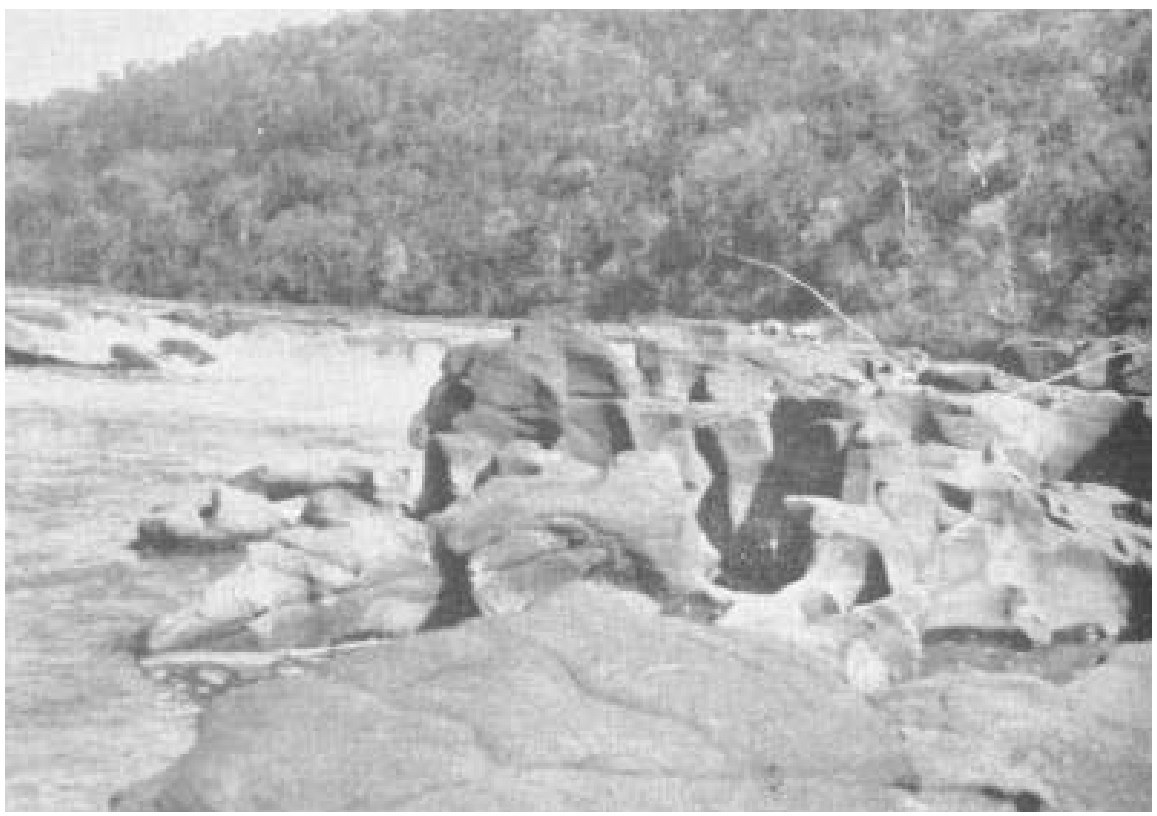

Fig. 96 - Permiano (inferior ?). Série Passa Dois. Afloramento de calcáreos das camadas Terezina (calcáreo Rocinha) no vale do rio Tibagí (cachoeira Caldeirão) abaixo do boqueirão da Serra dos Agudos. Terceiro planalto do Paraná.

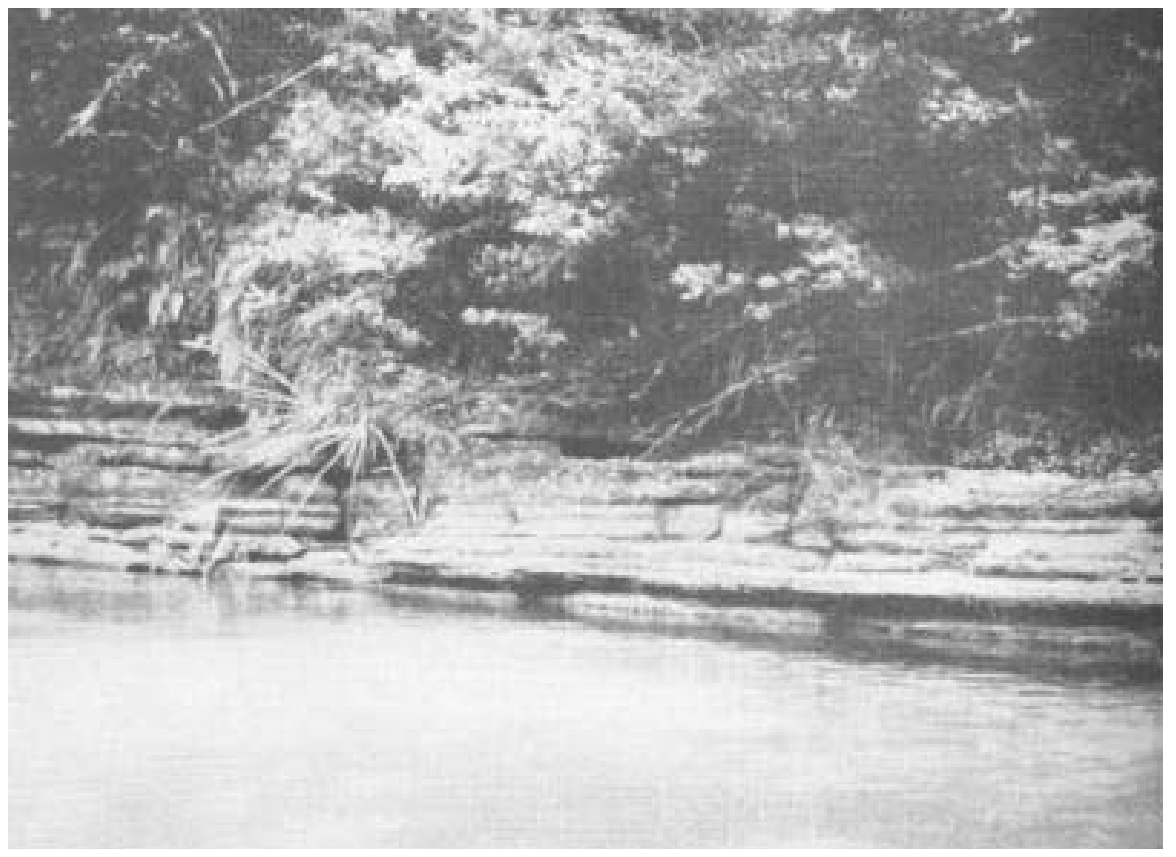

Fig. 97 - Permiano (inferior ?). Série Passa Dois. Bancos calcáreos, finamente estratificados, das camadas Terezina, em Terezina, no vale do rio Ivaí (487 m s.n.m.). Segundo planalto do Paraná. 


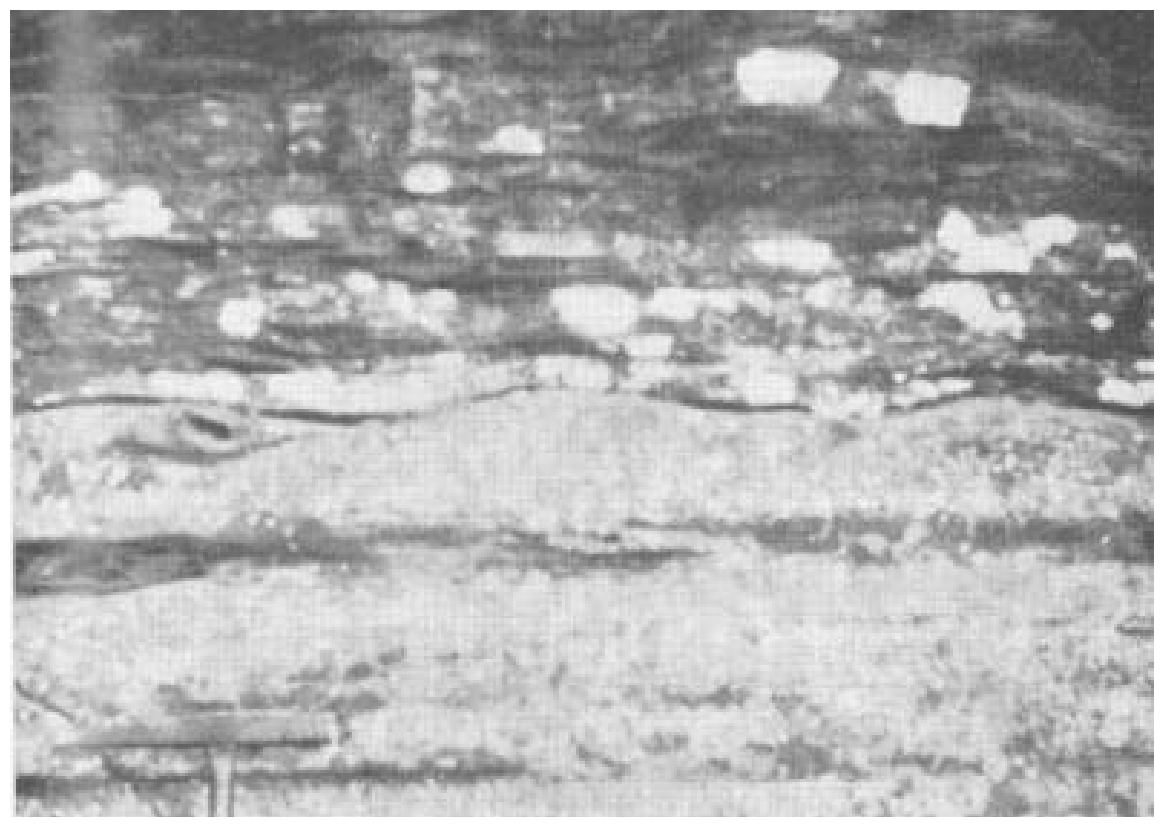

Fig. 98 - Permiano (inferior ?). Grupo Estrada Nova da série Passa Dois. Ripplemarks nos calcáreos das camadas Terezina, em Pedra Branca, vale do rio Ivaí. Segundo planalto do Paraná.

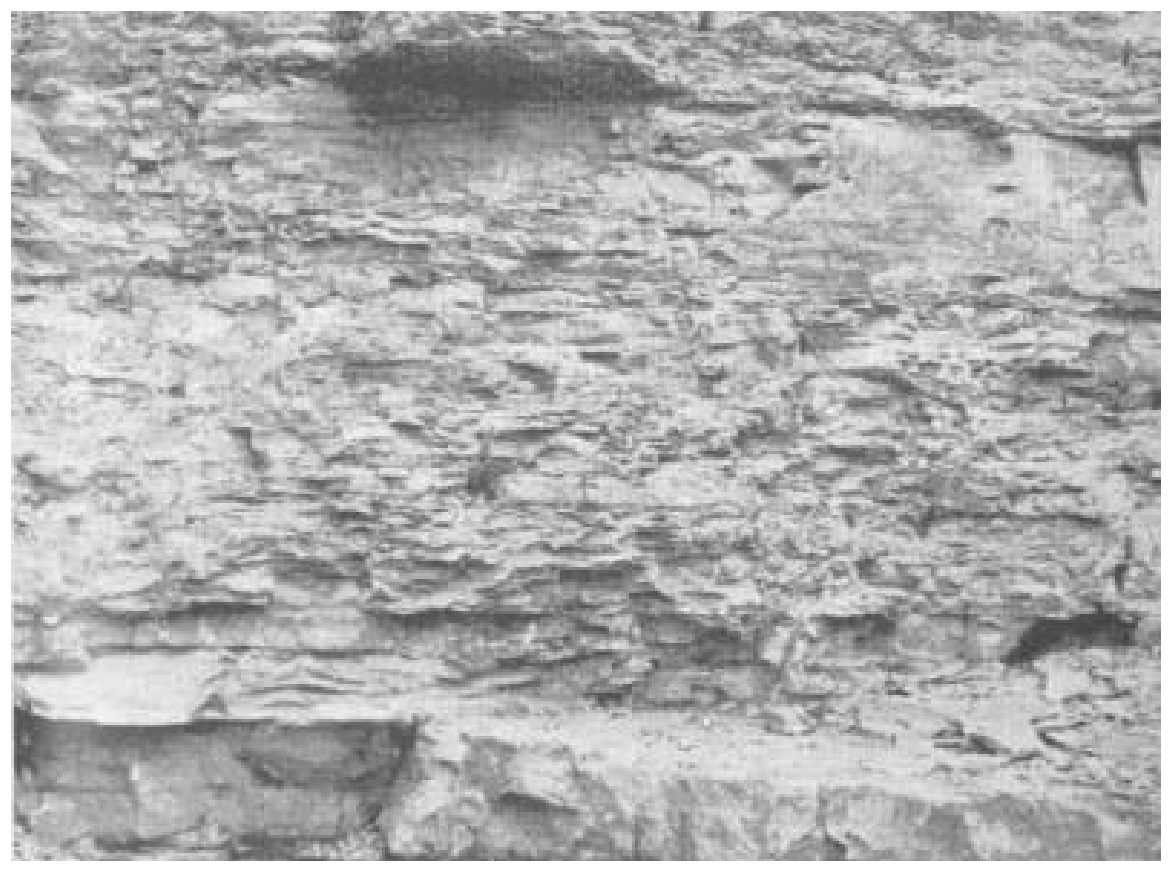

Fig. 99 - Permiano (inferior ?). Grupo Estrada Nova da série Passa Dois. Alternância de bancos calcáreos com xistos compactos, de coloração cinza-esverdeada, das camadas Terezina km 46 a oeste de Serra Alta na Serra Geral, Santa Catarina. 


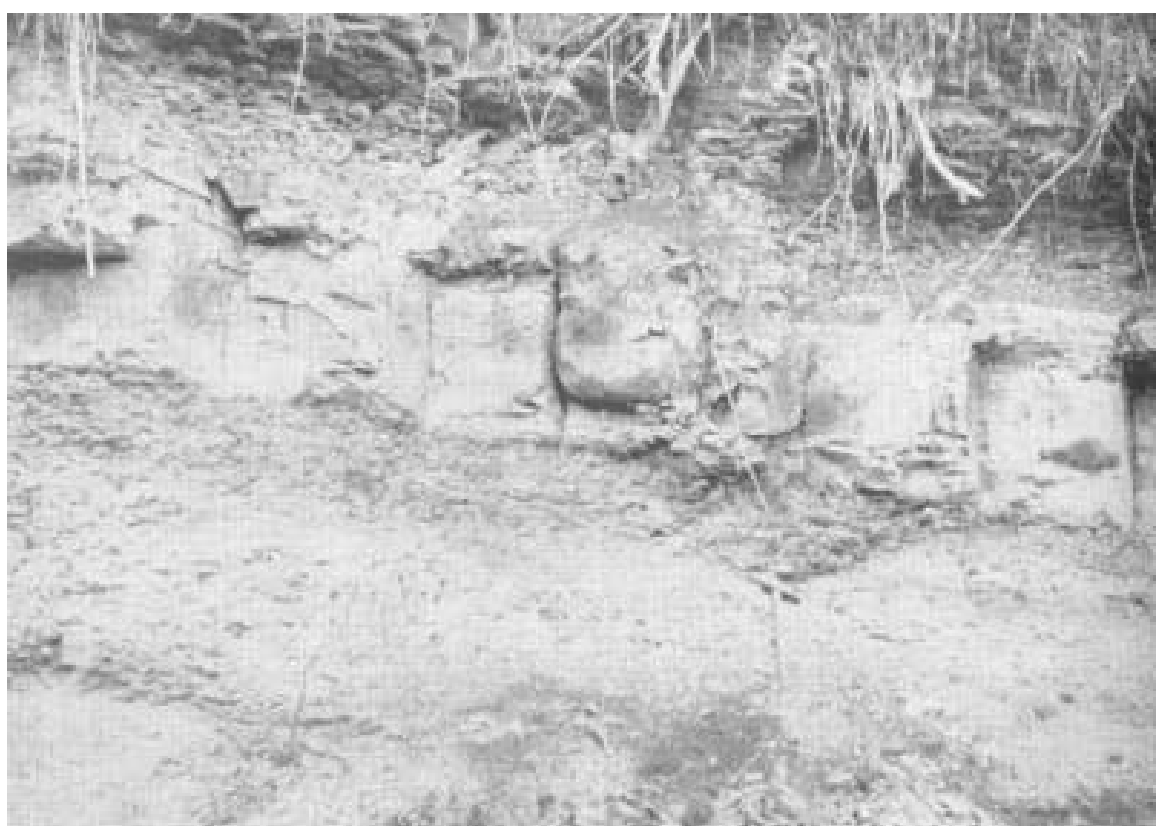

Fig. 100 - Permiano (inferior ?). Camadas Terezina - Serrinha da série Passa Dois. Banco de arenito avermelhado e nódulos calcáreos violáceos em folhelhos cinza-esverdeados. Banco fossilífero de Holdhaus com Solenomorpha entre Malet e Dorizon. Segundo planalto do Paraná.

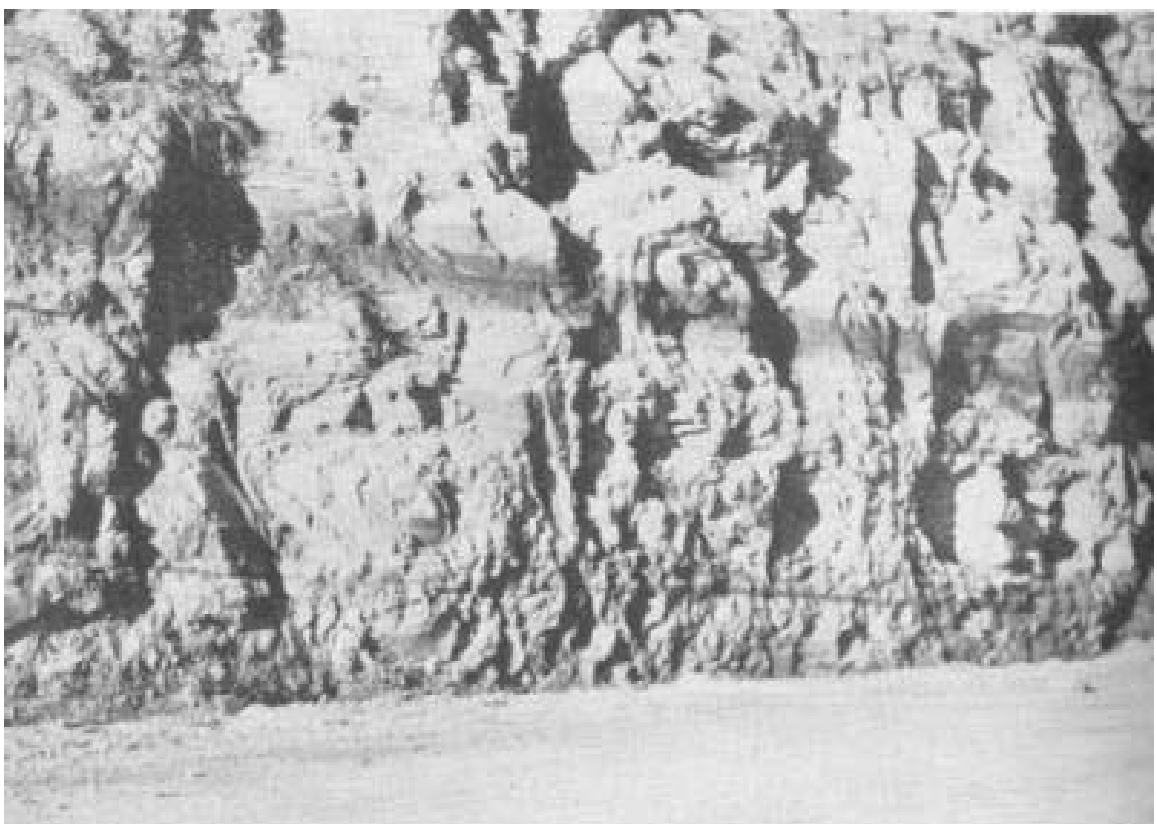

Fig. 101 - Permiano. Camadas Terezina - Serrinha da série Passa Dois. Desagregação esferoidal típica dos horizontes areno-argilosos das camadas Terezina, entre km 110 e 111 a oeste de Prudentópolis. Segundo planalto do Paraná. 


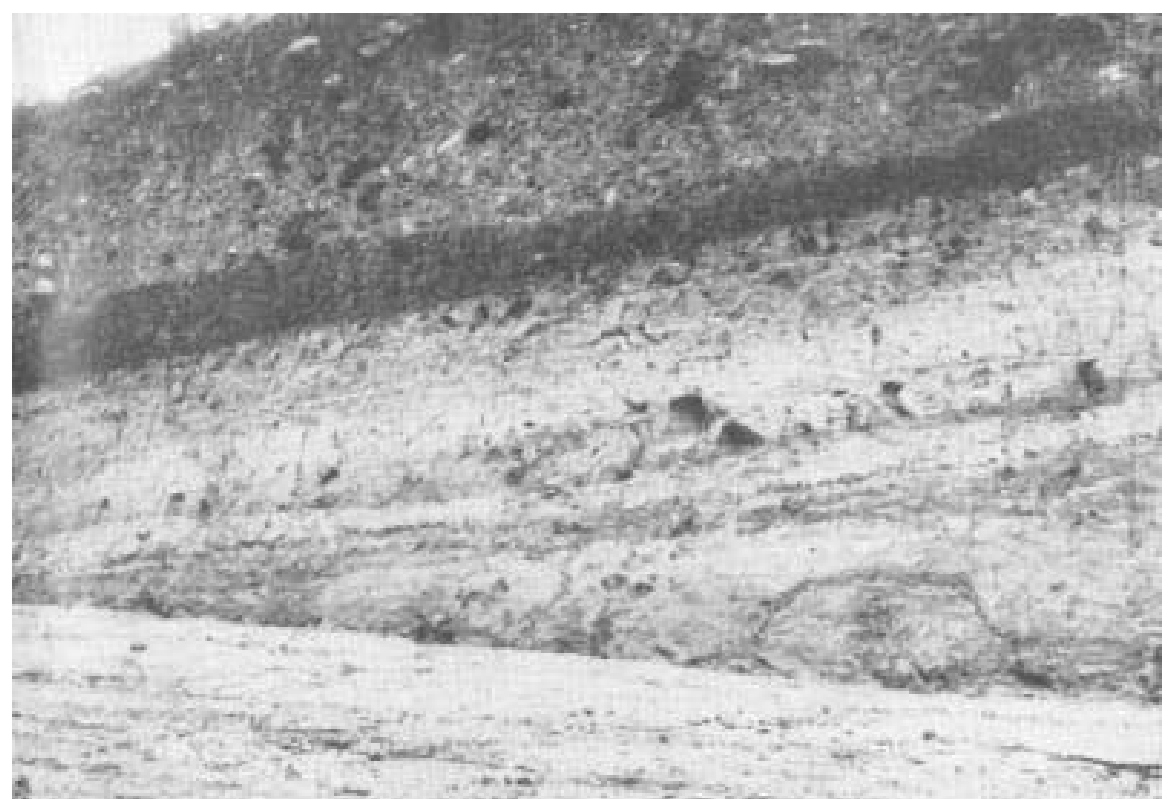

Fig. 102 - Permiano (superior ?). Série Passa Dois. Formação Esperança do grupo Rio do Rasto. Camadas de coloração variegada (verdes, avermelhadas, cinzento-azuladas e violáceas), areno-argilosas, com horizontes fossilíferos, ricos em Glossopteris e filópodos, em rio d'Areia (750 m). Segundo planalto do Paraná.

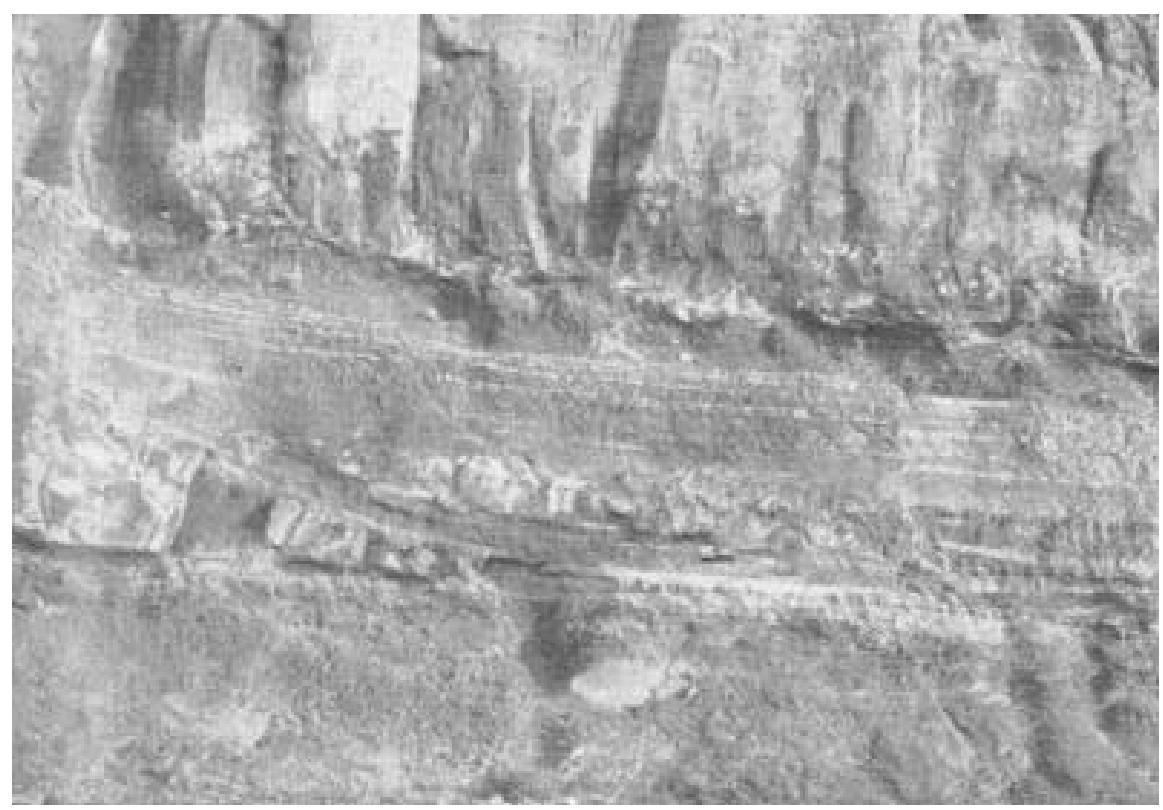

Fig. 103 - Limite do permiano (superior ?) com o triássico superior. Arenito Botucatu (fácies Piramboia) sobre folhelhos e siltitos verdes, violáceos e marron-avermelhados, com lentes e bancos de arenitos do grupo Rio do Rasto, na margem direita do rio Iguaçu (740 m). União da Vitória no segundo planalto do Paraná. 


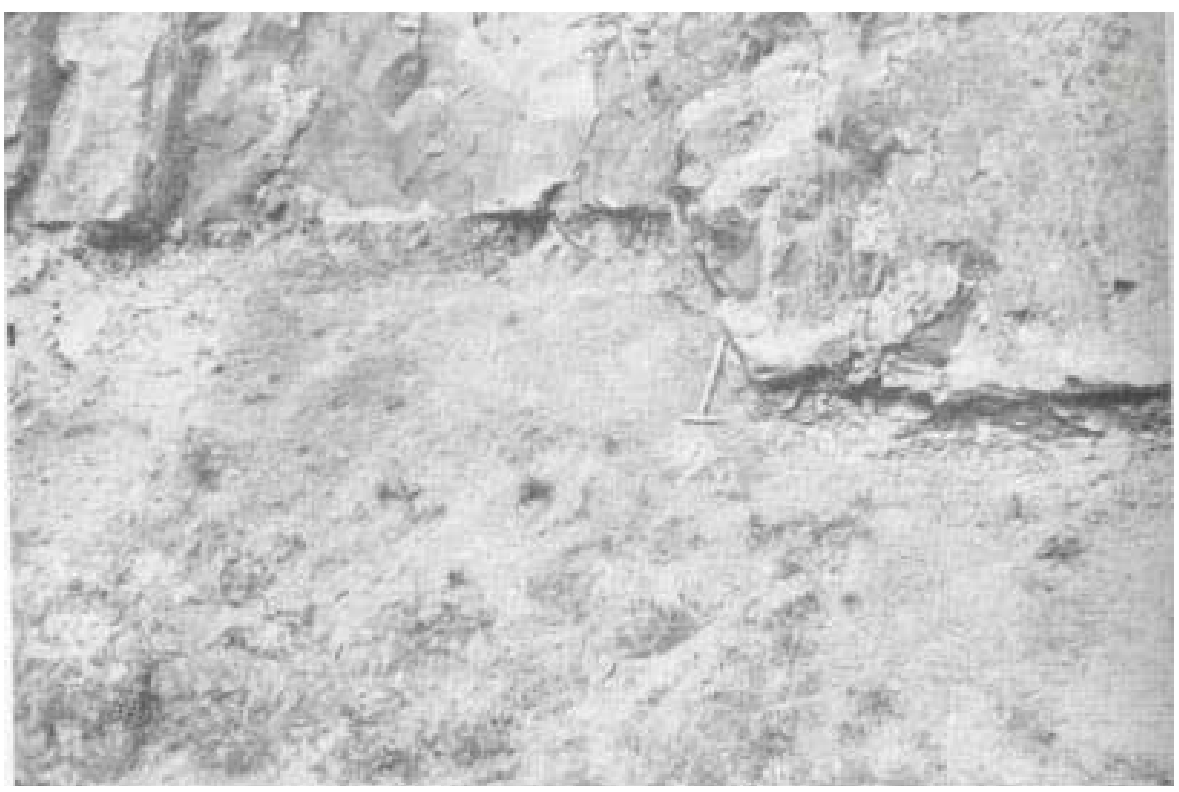

Fig. 104 - Permiano (superior ?) e triássico superior.Discordância de erosão entre cmadas argilosas, vermelhas, da formação Poço Preto do grupo Rio do Rasto com Estheria, e arenitos vermelhos na base do arenito Botucatu (1045 m s.n.m.), km 65 da estrada Lajes - Bom Retiro, Serra Bocaína do Sul, planalto de Santa Catarina.

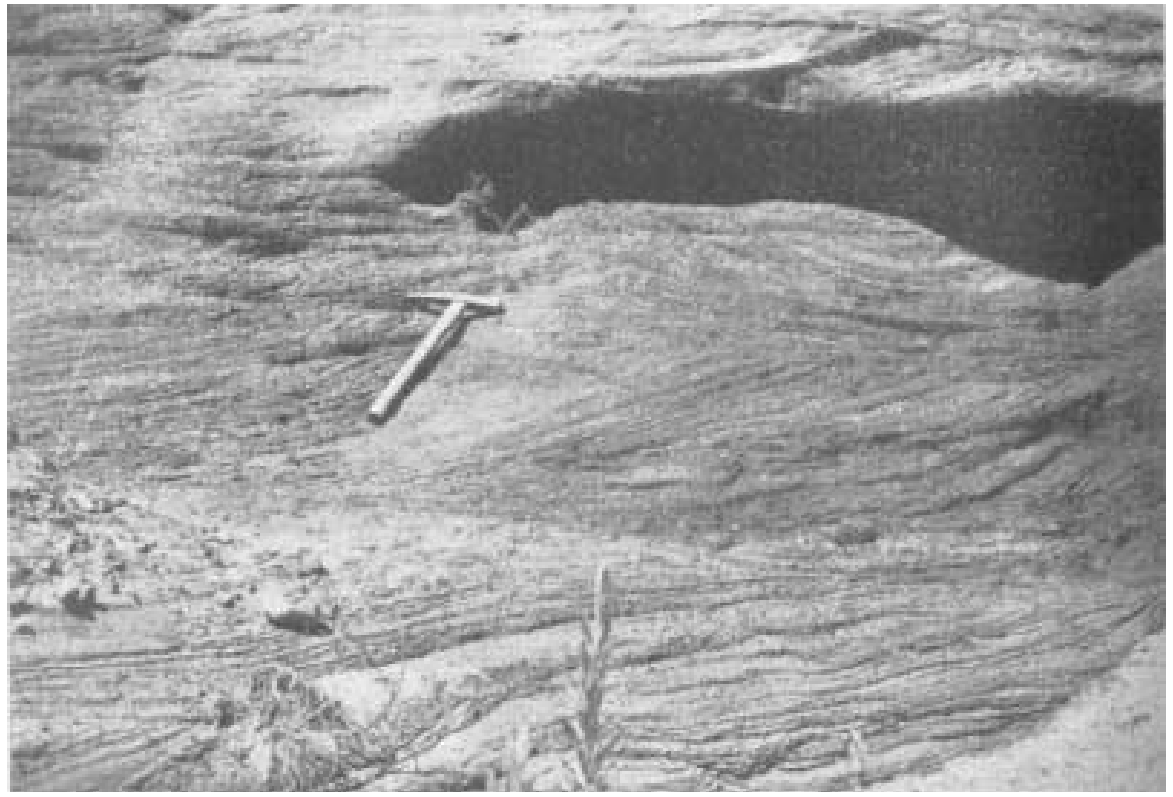

Fig. 105 - Triássico superior (Keuper). Arenitos vermelhos de estratificação cruzada rasa da formação Santa Maria em Alemoa. Abaixo destes arenitos jazem os horizontes argilosos com restos de ossos fósseis dde Rhynchosauridae, Cynodontia e Pseudosuchia. Santa Maria da Boca do Monte, Rio Grande do Sul. 


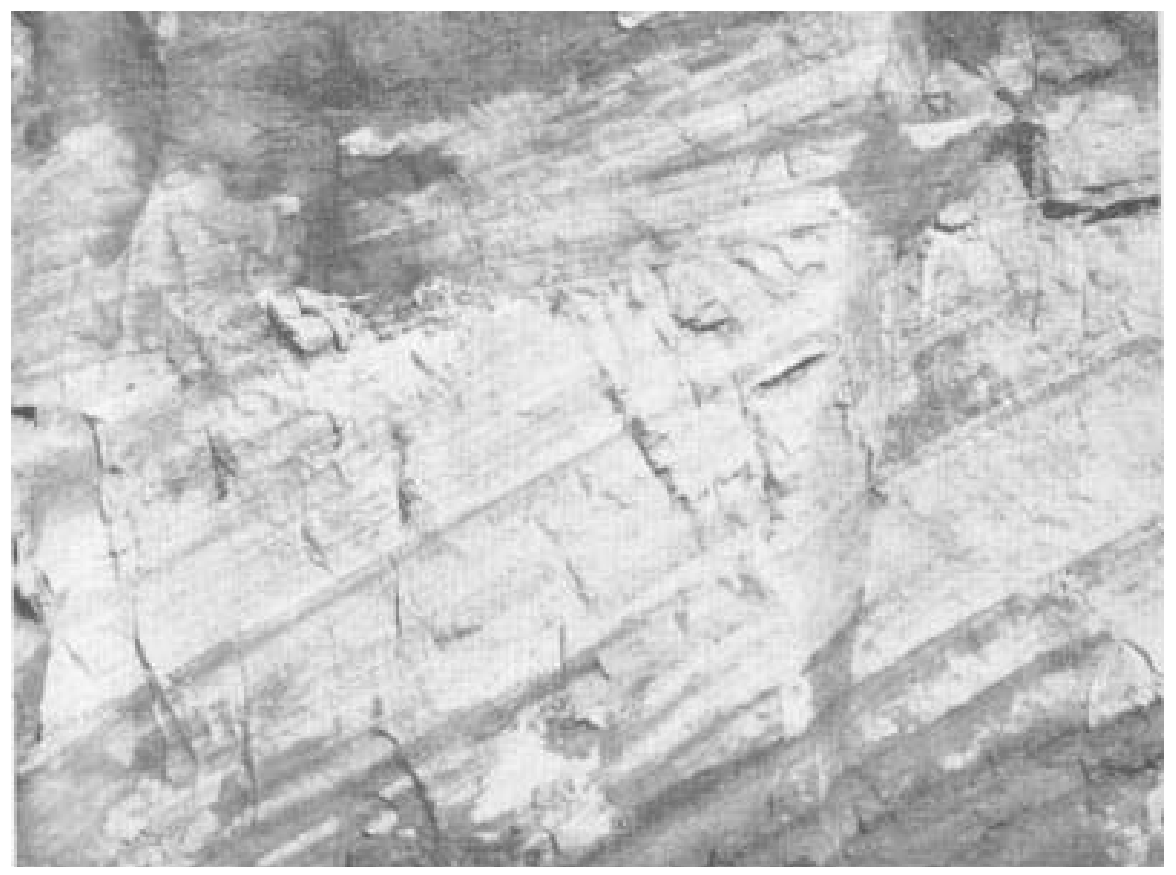

Fig. 106 - Triássico superior (rético ?). Estratificação cruzada do arenito Botucatu, na Serra da Boa Esperança a sueste de Araíporanga (ex-São Jerônimo) em 1120 m s.n.m. Terceiro planalto do Paraná.

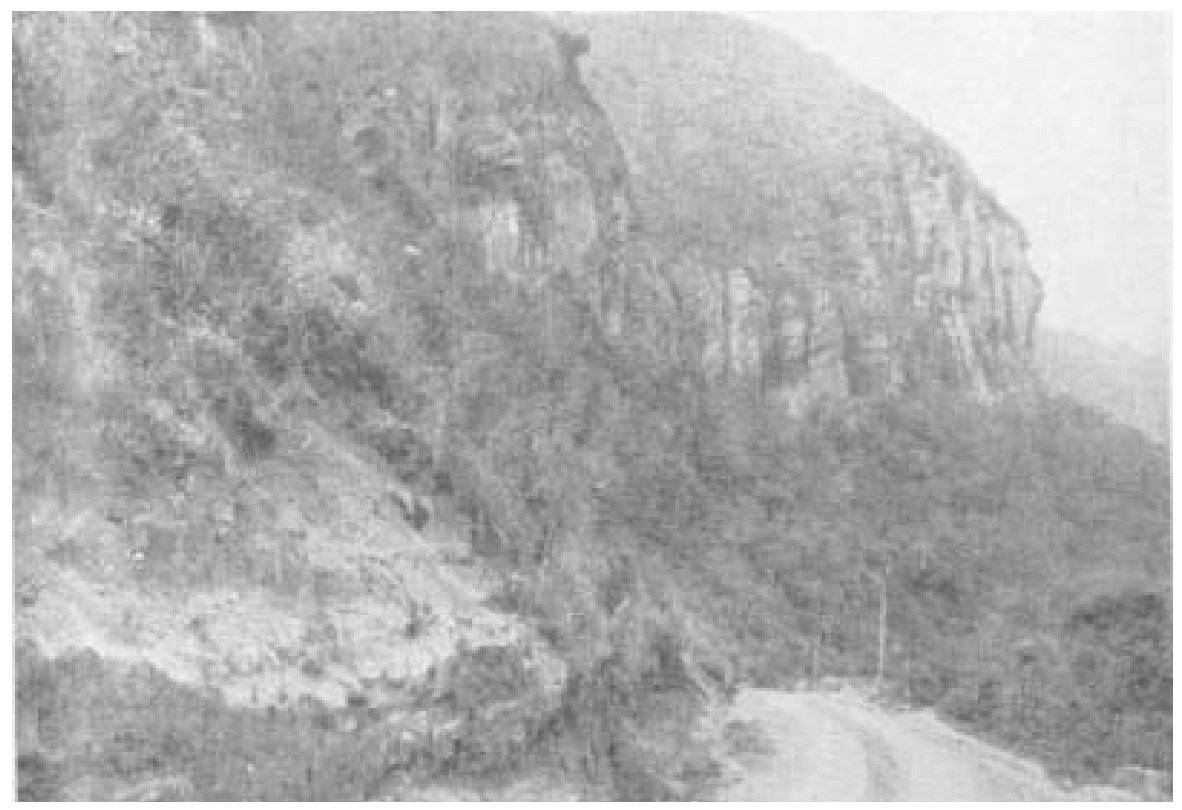

Fig. 107 - Triássico superior (rético ?). Série São Bento. Arenito Botucatu acima do arenito vermelho, representado na fig. 104. 1051 a 1170 m s.n.m. na Serra Bocaína do Sul, km 65 da estrada Lajes - Bom Retiro. Planalto de Santa Catarina. 


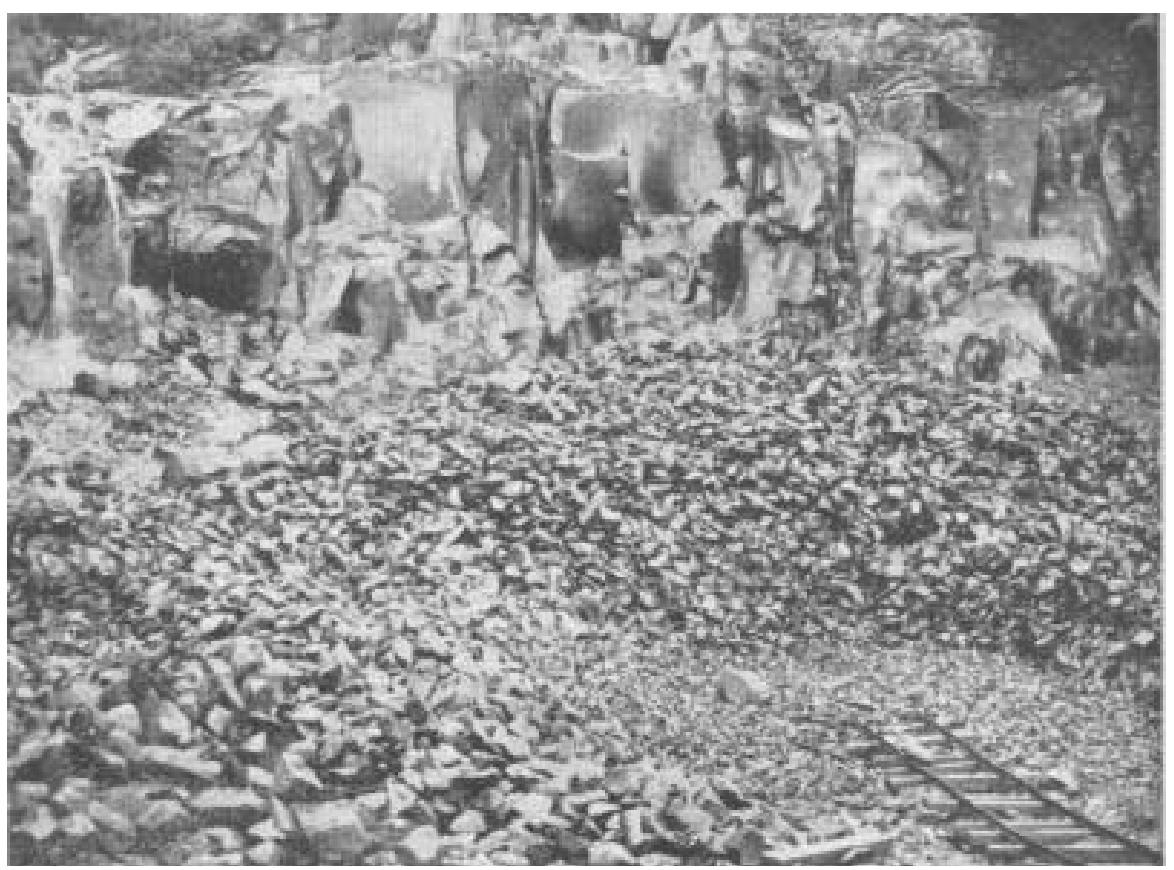

Fig. 108 - Triássico superior (rético ?) ou jurássico (liássico ?). Série São Bento. Lençóis de diabásio de granulação fina (trapp do Paraná), em 1050 m s.n.m. na Serra da Boa Esperança, perfil Prudentópolis - Guarapuava. Terceiro planalto do Paraná.

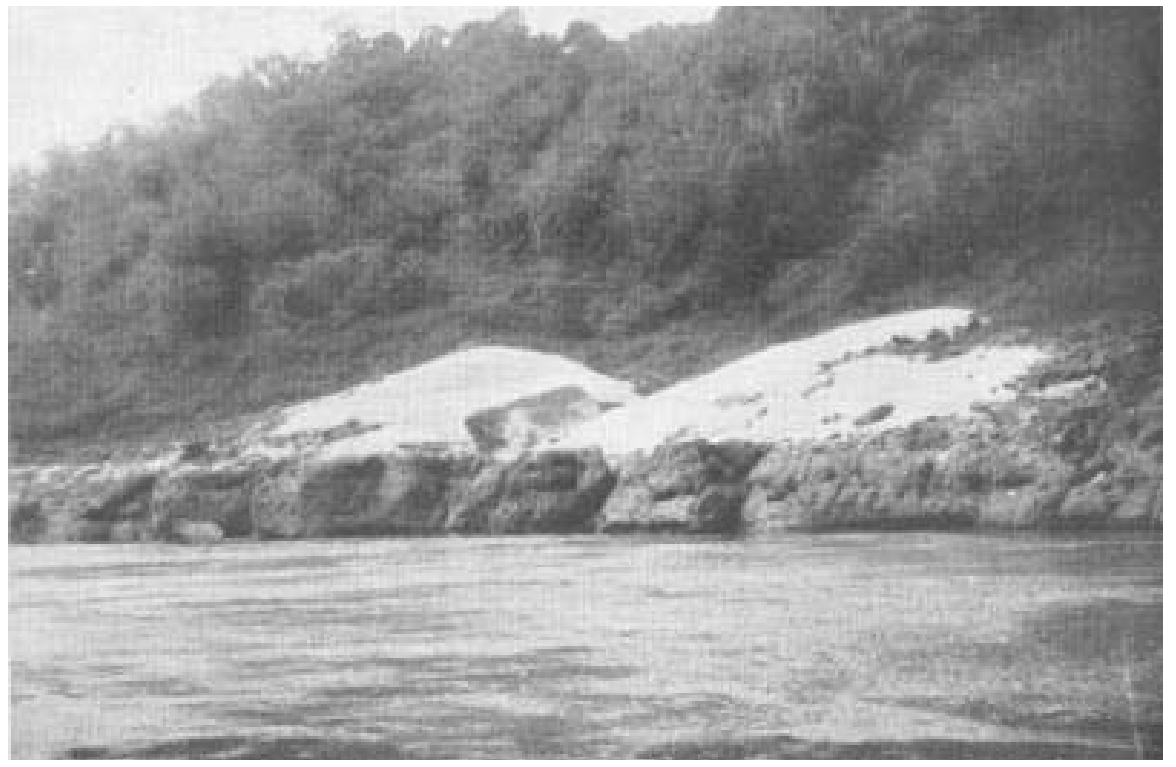

Fig. 109 - Cones de areia, depositados num terraço de lençóis do trapp, na embocadura de um afluente no cañon do rio Paraná. Ao norte de Porto Britânia, na margem paraguaia. 


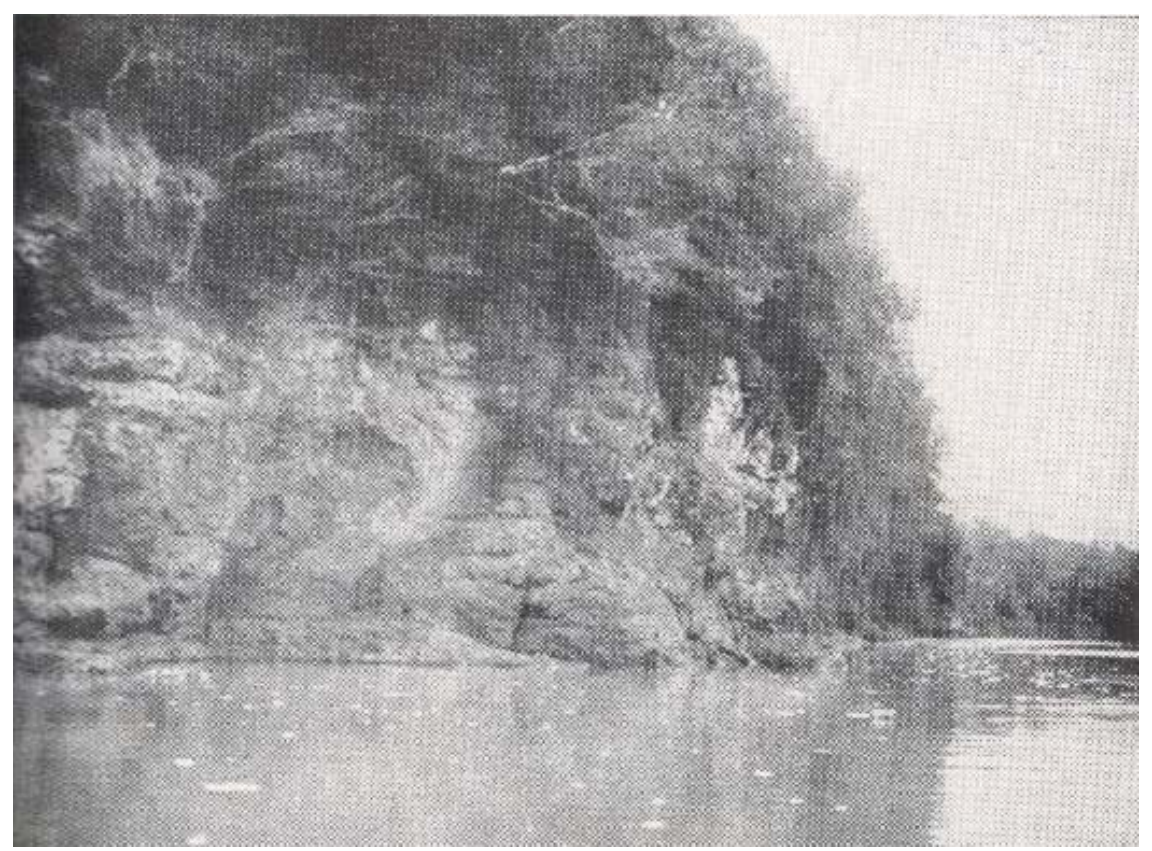

Fig. 110 - Triássico-jurássico (liássico ?). Série São Bento. Lava cordada (Fladenlava) na margem esquerda do rio Ivaí, a oeste da foz do rio Corumbataí na cota de 296 m. Terceiro planalto do Paraná.

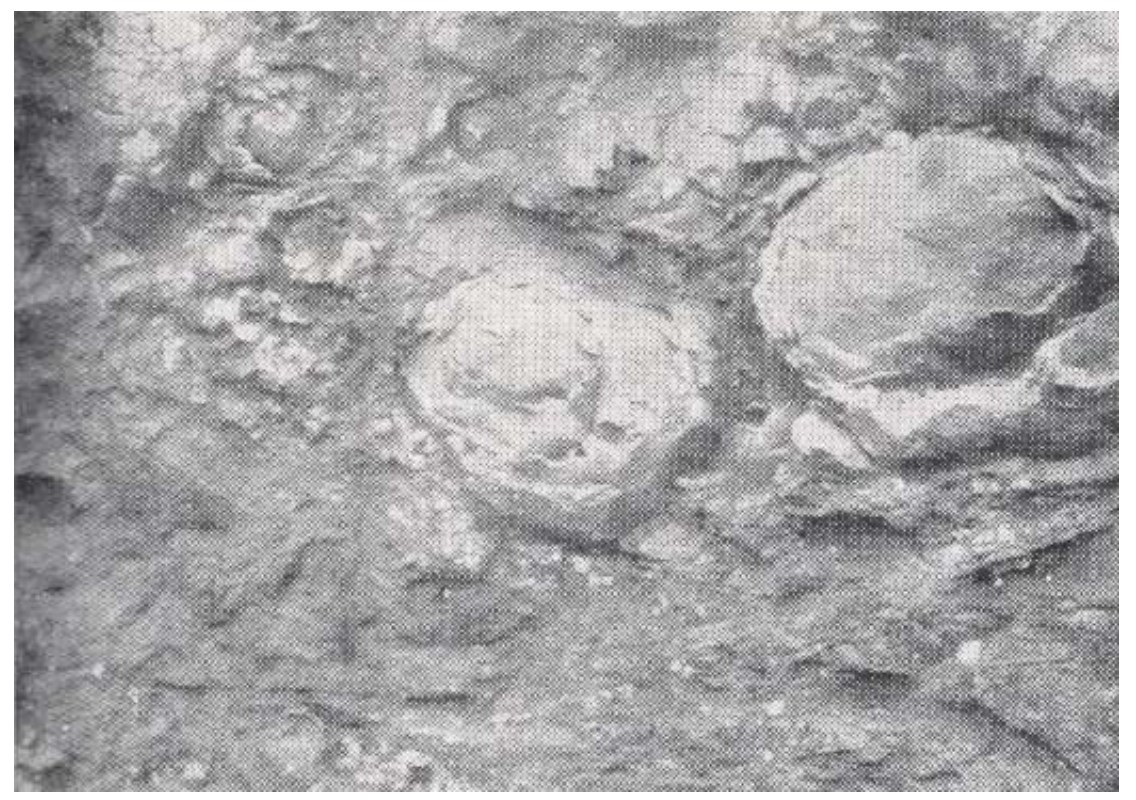

Fig. 111 - Triássico-jurássico (liássico ?). Série São Bento. Blocos de diabásio com desagregação esferoidal (lava em blocos = Blocklava) dos lençóis de trapp do Paraná. Perfil Guará (ex-Bananas) - Guarapuava na cota de 110 m. Terceiro planalto do Paraná. 


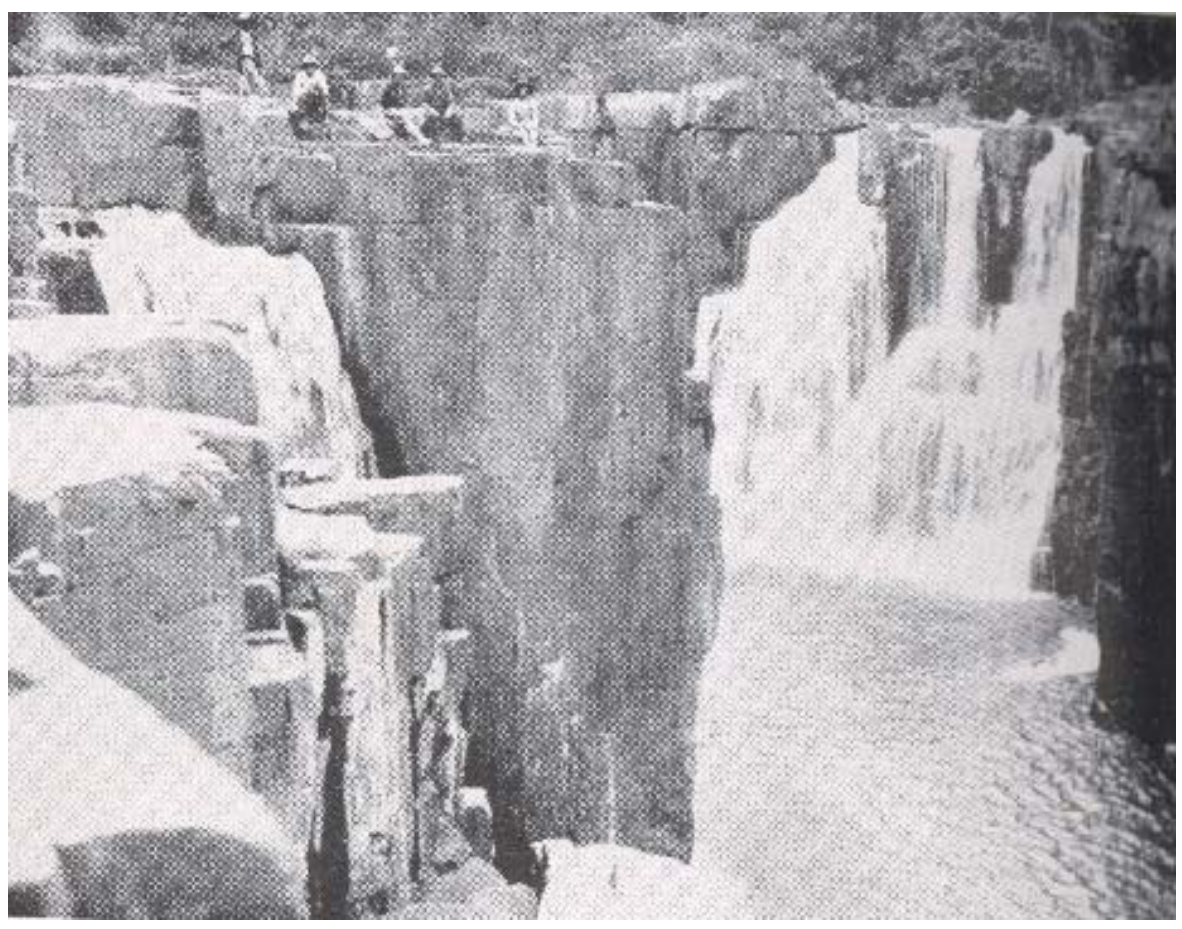

Fig. 112 - Triássico (jurássico ?). Vale do rio Tibagí entalhado num dique de diabásio ao longo das diáclases, formando o salto Mauá (548 a 573 m s.n.m.). Segundo planalto do Paraná.

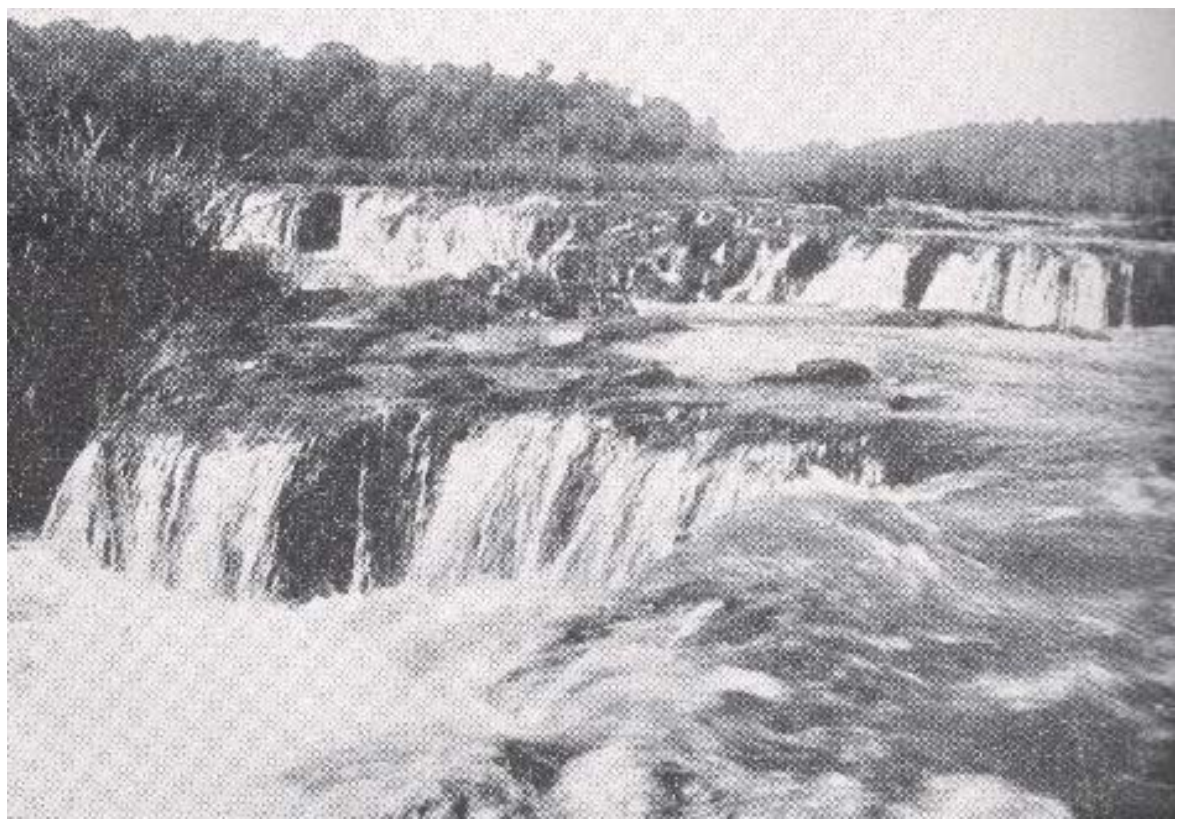

Fig. 113 - Triássico (jurássico ?). Série São Bento. Bordas escalonadas das chapas estruturais dos lençóis do trapp (meláfiros com drusas de heulandita), formando o salto das Bananeiras, entre 272 e 276 m s.n.m., no vale do rio Ivaí. Terceiro planalto do Paraná. 


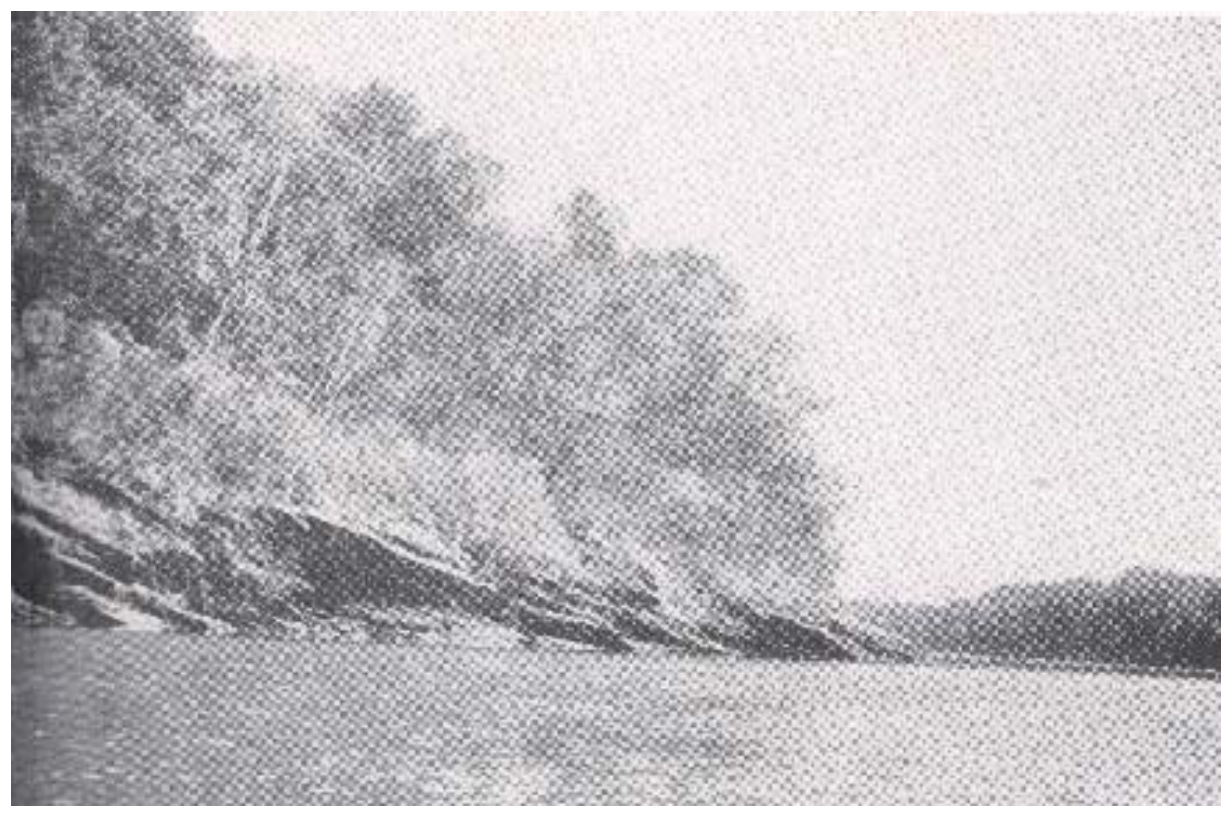

Fig. 114 - Jurássico-liássico (?).Série São Bento. Arenito Caiuá, aparentemente com inclinação par oeste, na margem sul do rio Ivaí, abaixo da corredeira de Ferro na cota de $234 \mathrm{~m}$. A inclinação aparente é motivada pela desagregação ao longo das linhas de estrutura da estratificação cruzada. Terceiro planalto do Paraná.

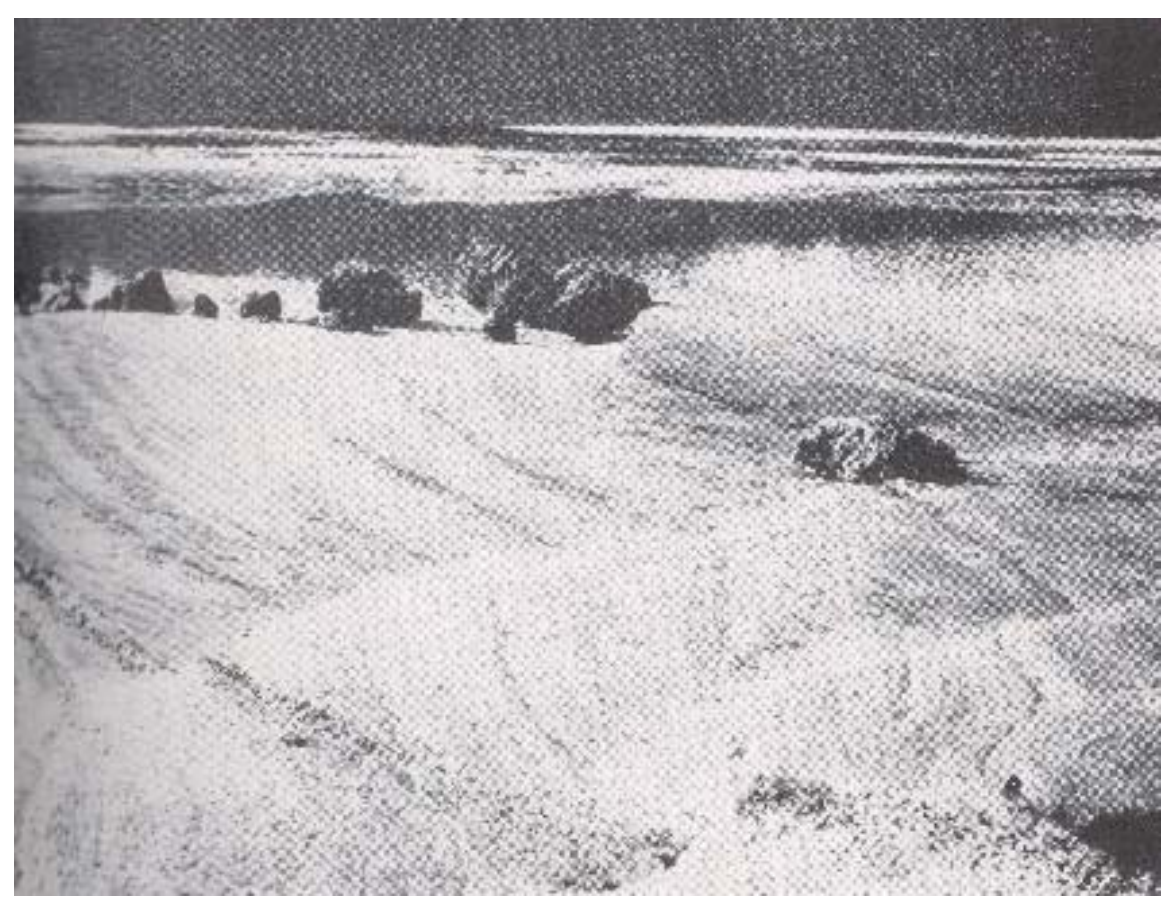

Fig. 115 - Jurássico-liássico (?).Série São Bento. Blocos de canga expostos pela desagregação do arenito Caiuá Superfície de um estrato com estrutura entrecruzada eólica no leito do rio Ivaí, na cota de $232 \mathrm{~m}$. Terceiro planalto do Paraná. 


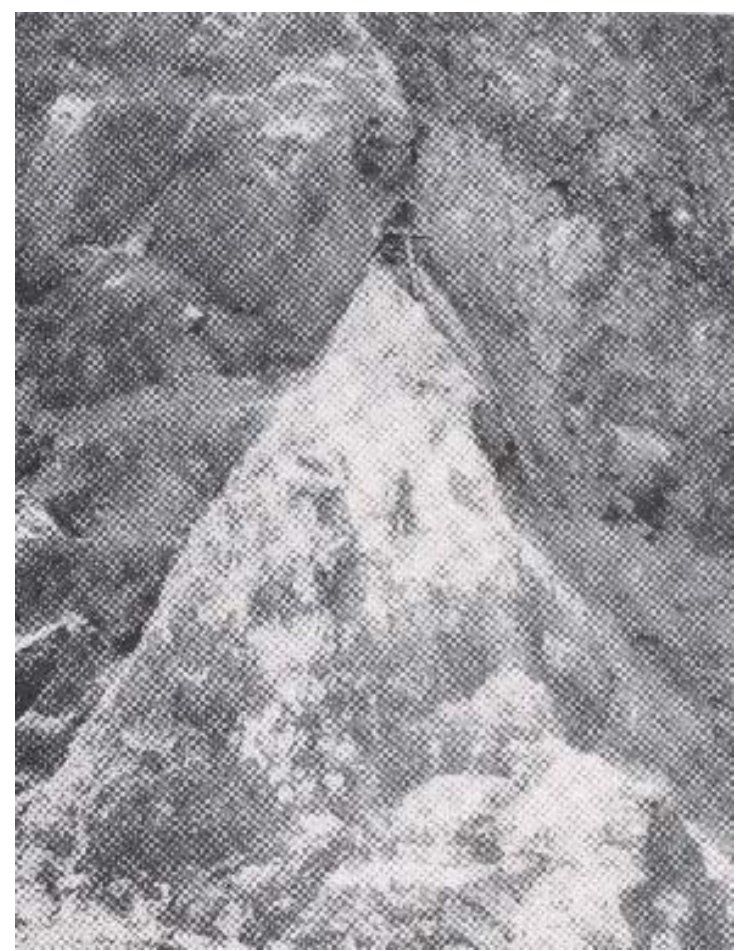

Fig. 116 - falha entre o arenito das Furnas e filitos da série Açunguí originada por um dique de diabásio, em Serradinha. Escarpa devoniana - Paraná.

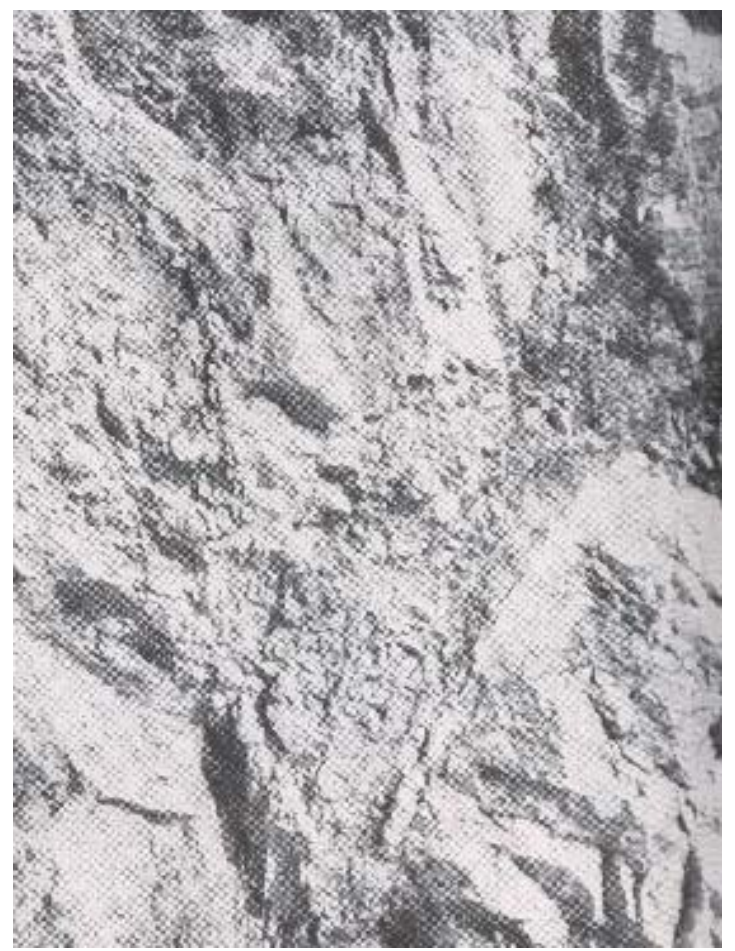

Fig. 117 - Camadas glaciais do grupo Itararé (carbonífero superior), dobradas e semimetamorfoseadas, nas elevações da Serra do Mar. Estes afloramentos lembram as camadas glaciais metamorfoseadas e perturbadas da série Lavras, na chapada de Diamantina em Minas Gerais. Serra São Miguel - Santa Catarina. 


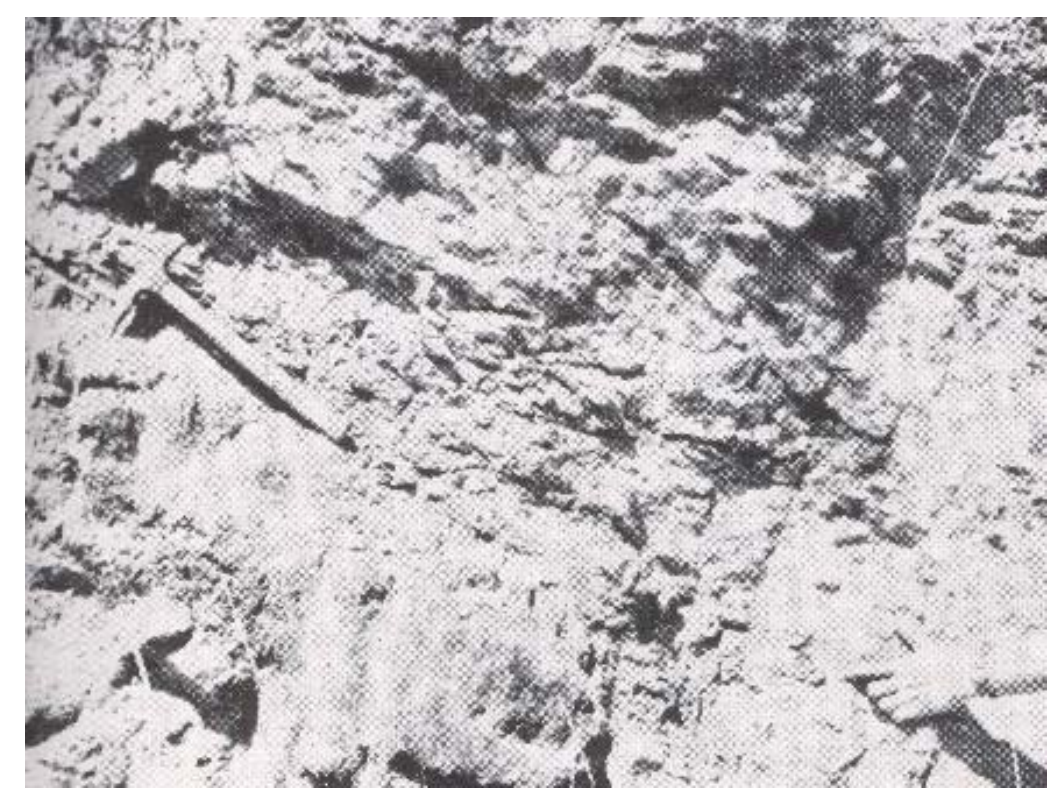

Fig. 118 - Falha entre granito e depósitos de drift glacial do grupo Itararé, em Ribeirão Grande, no vale do rio Tubarão - braço Norte. O martelo marca o limite entre granito e camadas glaciais. À direita aparece o flanco sul da falha, dirigida para $\mathrm{N} 70^{\circ} \mathrm{W}\left(290^{\circ}\right.$ azimute magn.). Seixos e material de drift na parte afundada das camadas glaciais (vide fig. 14a). Orla da Serra Geral em Santa Catarina.

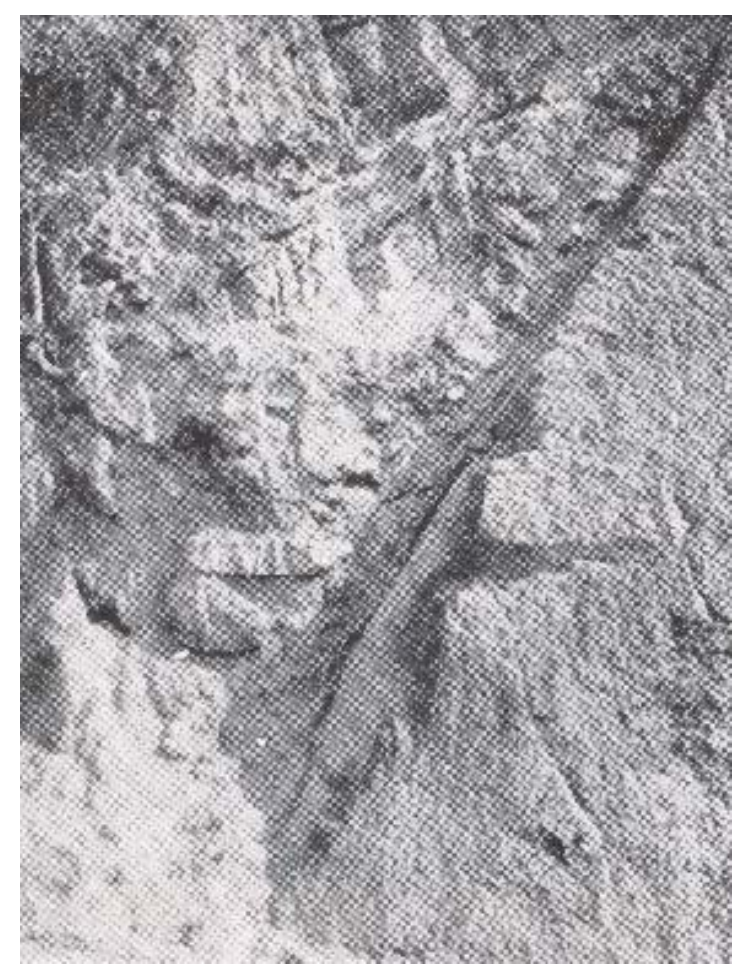

Fig. 119 - Falha transversal em Quebra Dente nas cabeceiras do rio do Sul. Bloco de camadas glaciais do grupo Itararé em forma de cunha afundado entre granito. À direita: o granito e à esquerda: camadas glaciais. O plano de falha é dirigido para $\mathrm{N} 345^{\circ} \mathrm{W}$ (magn.), mergulhando $67^{\circ}$ para NE. Orla da Serra Geral em Santa Catarina. 


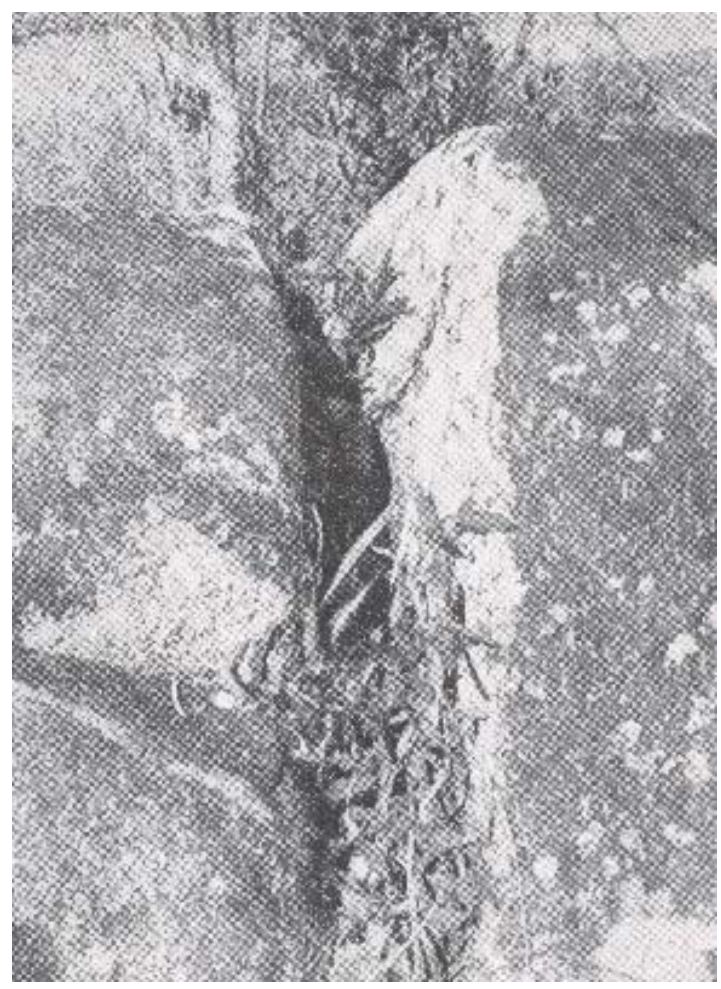

Fig. 120 - Quaternário antigo. Bloco de granito com rompimento de núcleo na mata da Serra do Mar, na cota de 1010 m, do flanco norte do Pico Caratuba. Formas antigas de desagregação mecânica em virtude de acentuados contrastes de temperatura de um clima semi-árido. Tais blocos acham-se atualmente na sombra da mata pluvial. Serra Ibiteraquire - Paraná.

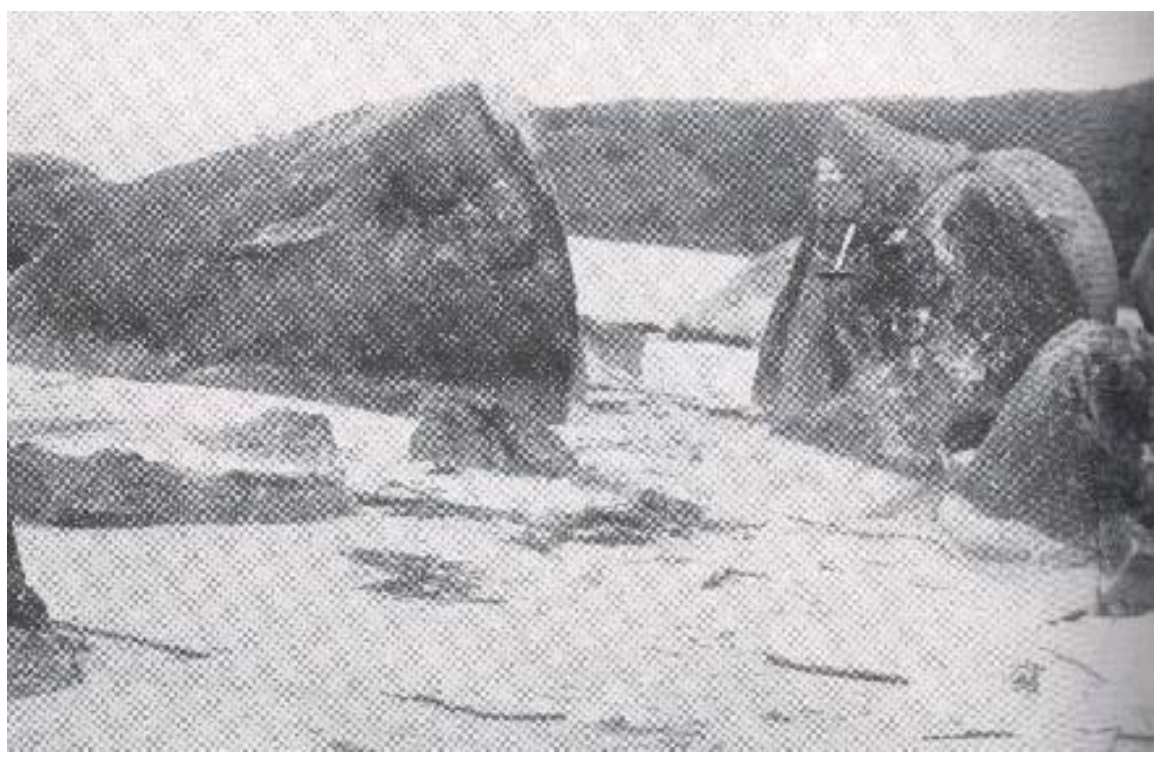

Fig. 121 - Quaternário recente. Recente rompimento de núcleo de um bloco de gnais-granito, na praia de Caiobá. Este tipo de rompimento é motivado pelos contrastes de temperatura entre a parte basal, banhada pela água, e a parte superior exposta à intensa insolação. Zona litoral do Paraná. 


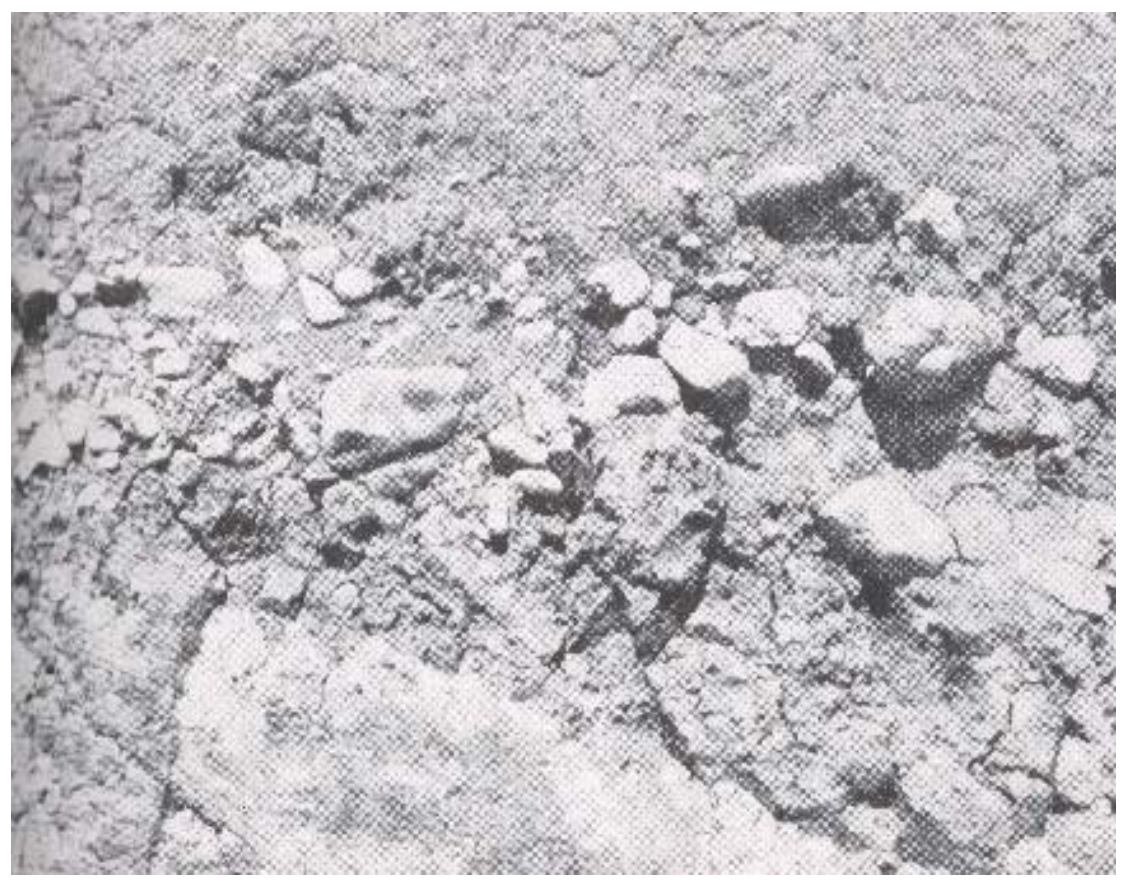

Fig. 122 - Quaternário antigo. Conglomerados fluviais nas alturas das colinas entre Campo Comprido e Passa Una. Os conglomerados jazem diretamente sobre gnais decomposto e são cobertos por camadas areno-argilosas. Primeiro planalto do Paraná.

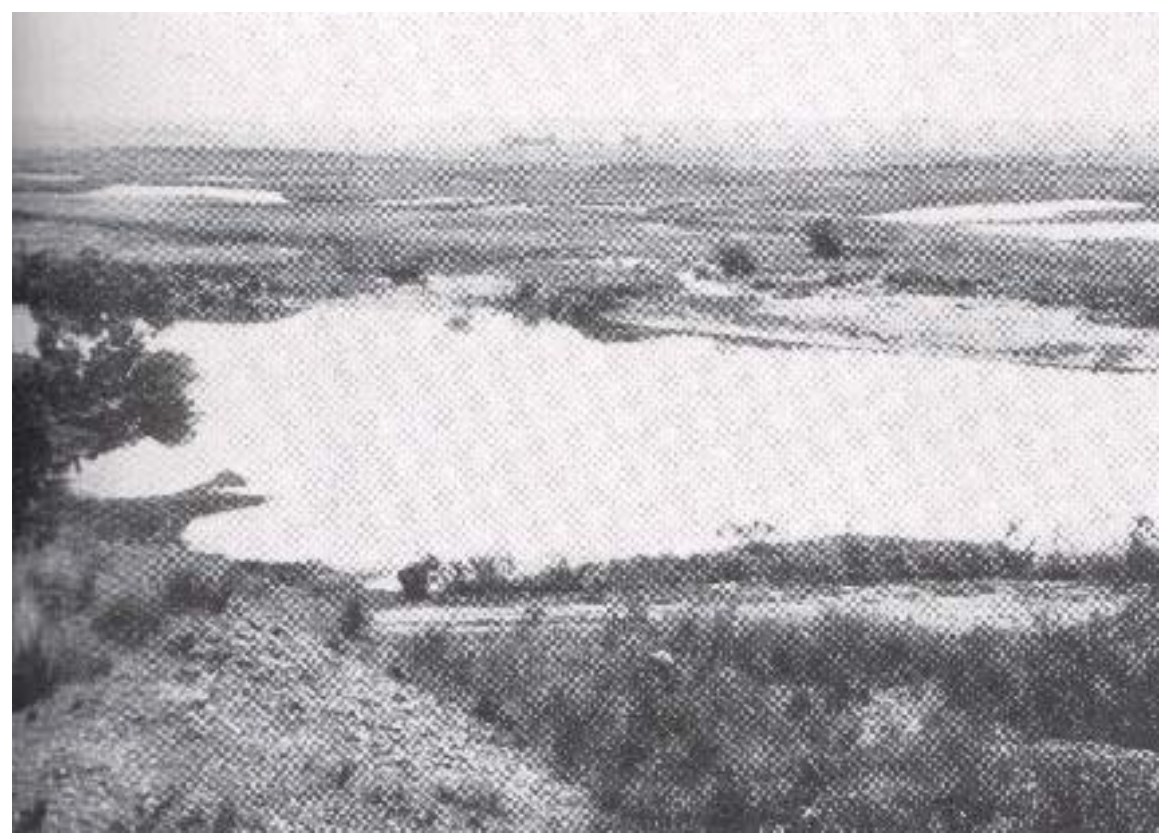

Fig. 123 - Quaternário recente. Vasta várzea de inundação do curso superior do rio Tibagí com meandros e águas estagnadas, ao sul de Ponta Grossa. Segundo planalto do Paraná. 


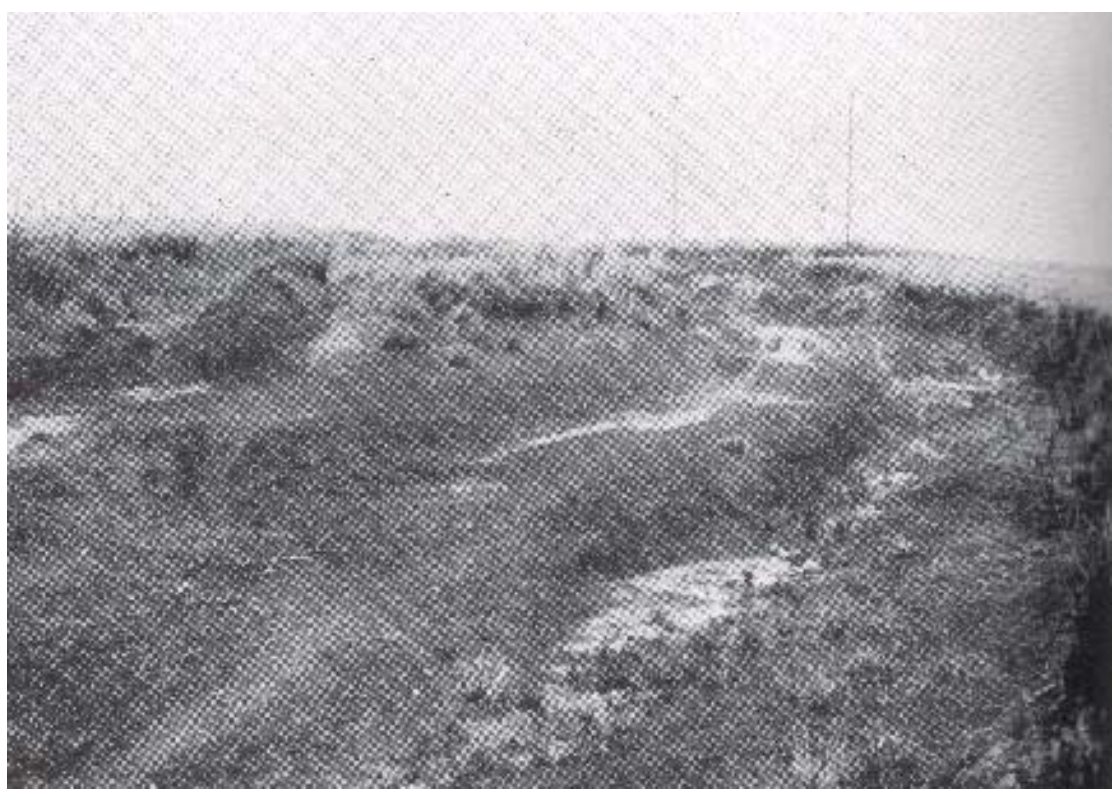

Fig. 124 - Quaternário recente. Erosão pluvial ao longo da antiga estrada de rodagem Ponta Grossa - Piraí-Mirim. Fase inicial de uma voçoroca. Em 1089 m s.n.m. no segundo planalto do Paraná.

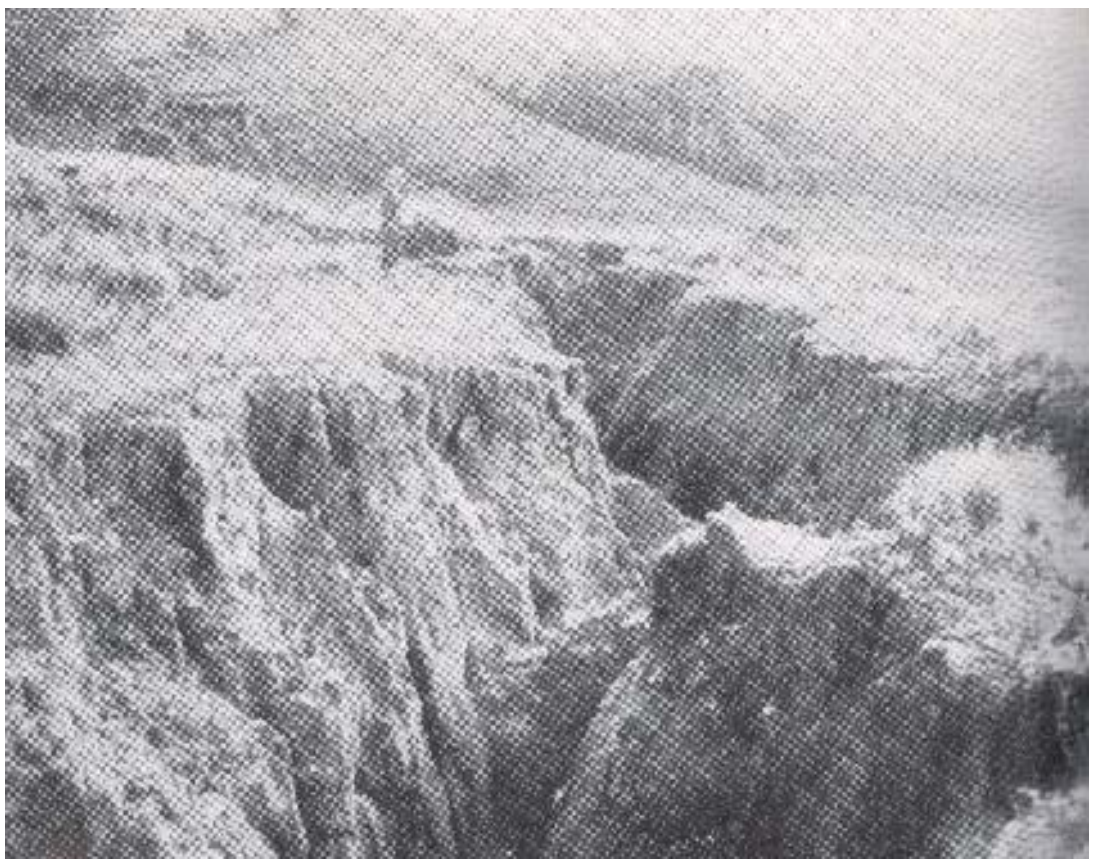

Fig. 125 - Quaternário recente. Fase avançada da erosão pluvial na mesma estrada. A voçoroca na cota de $1060 \mathrm{~m}$ tem uma profundidade de 8 a $10 \mathrm{~m}$. Segundo planalto do Paraná. 


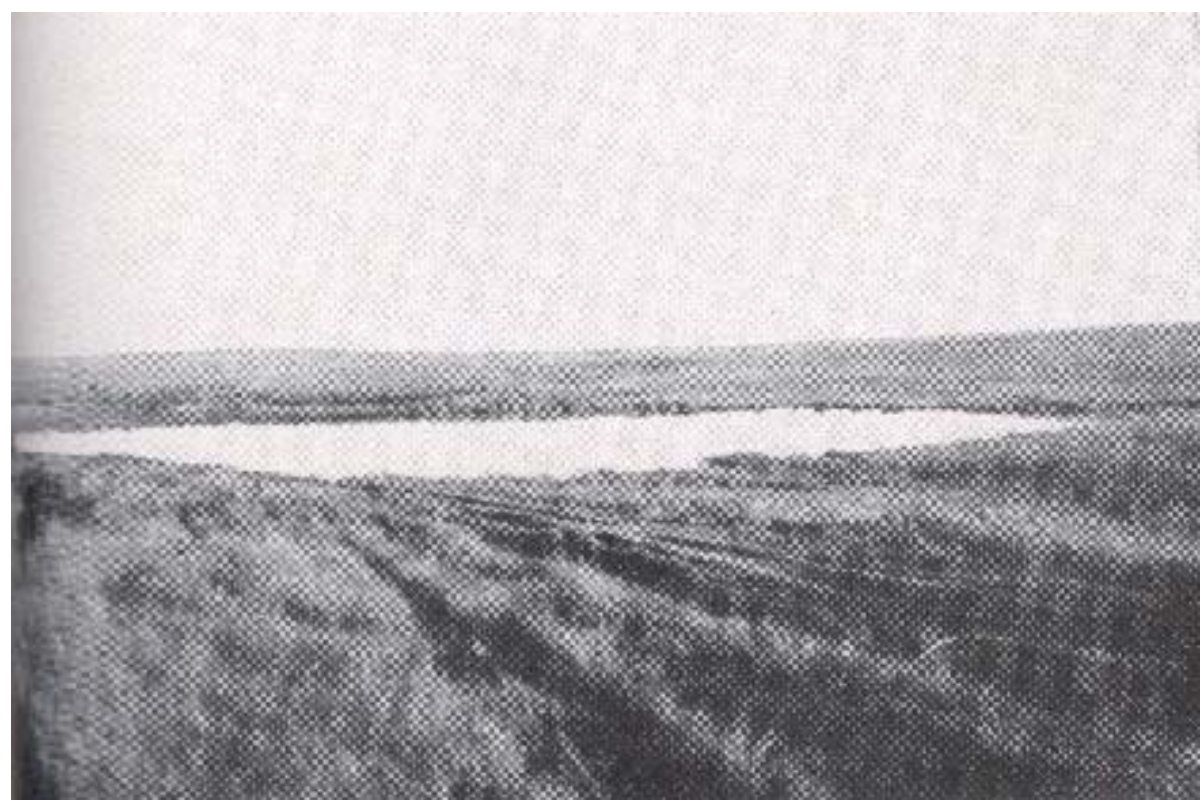

Fig. 126 - Quaternário recente. Lagoa em depressão rasa nos Campos Gerais, em Boa Vista (1223 m s.n.m.), formada pela ação conjunta da decomposição química, erosão mecânica e animal. Durante o período seco, as depressões sofrem leve deflação diferencial; no período chuvoso processa-se afofamento devido à ação química pela infiltração das águas. Segundo planalto do Paraná.

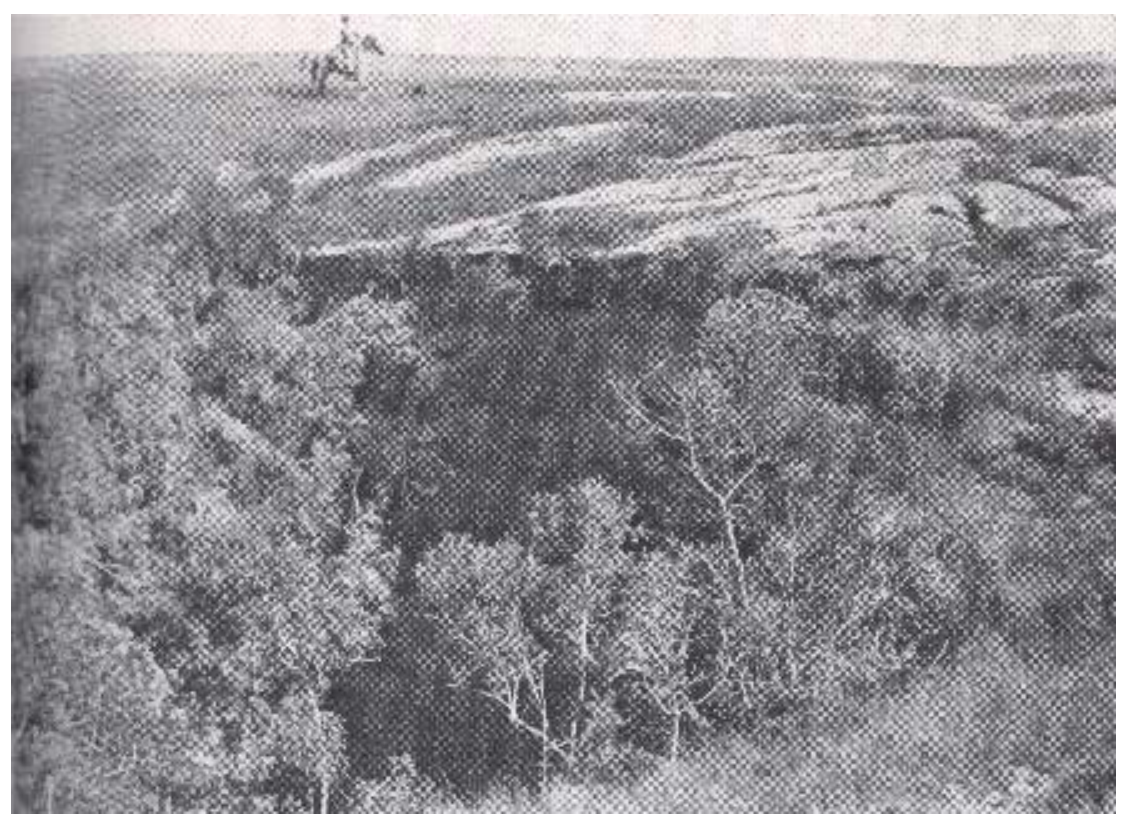

Fig. 127 - Quaternário recente. Poço de desabamento doliniforme no arenito das Furnas, nos Campos Gerais em Joaquim Muritinho. Segundo planalto do Paraná. 


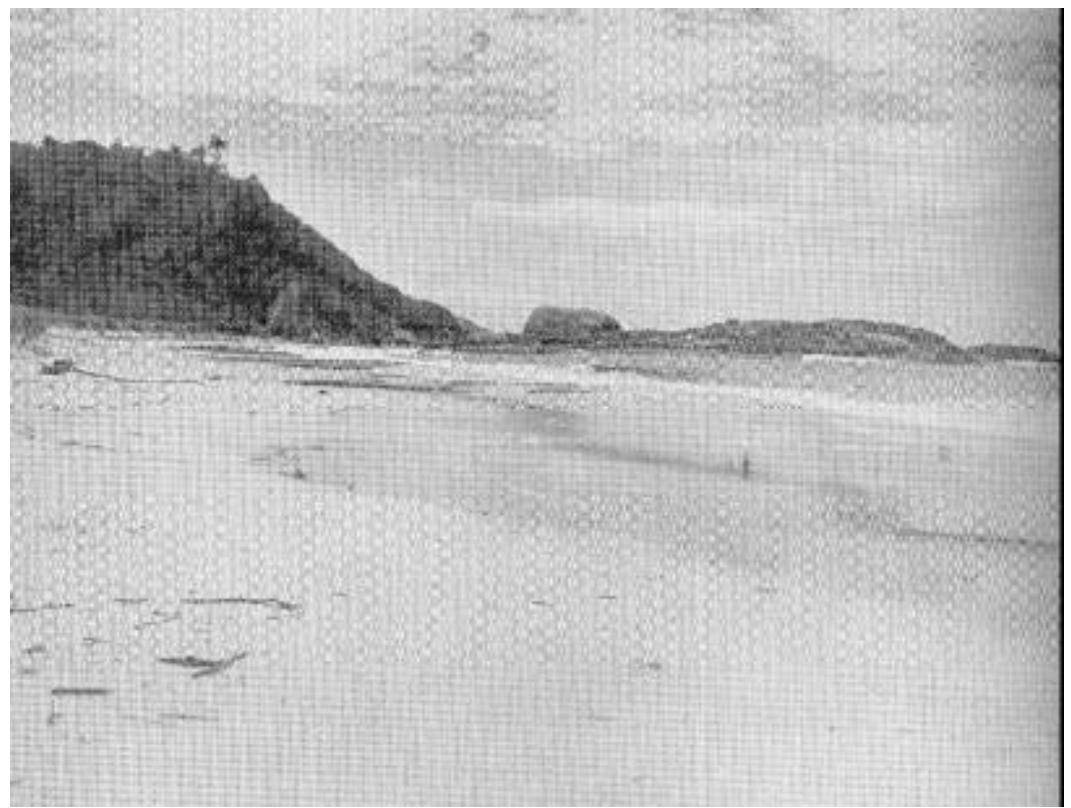

Fig. 128 - Quaternário. Diferentes níveis de abrasão em 7,5 m, 10 m e 30 m s.n.m., em Brejatuba. Praia do Sul - Paraná.

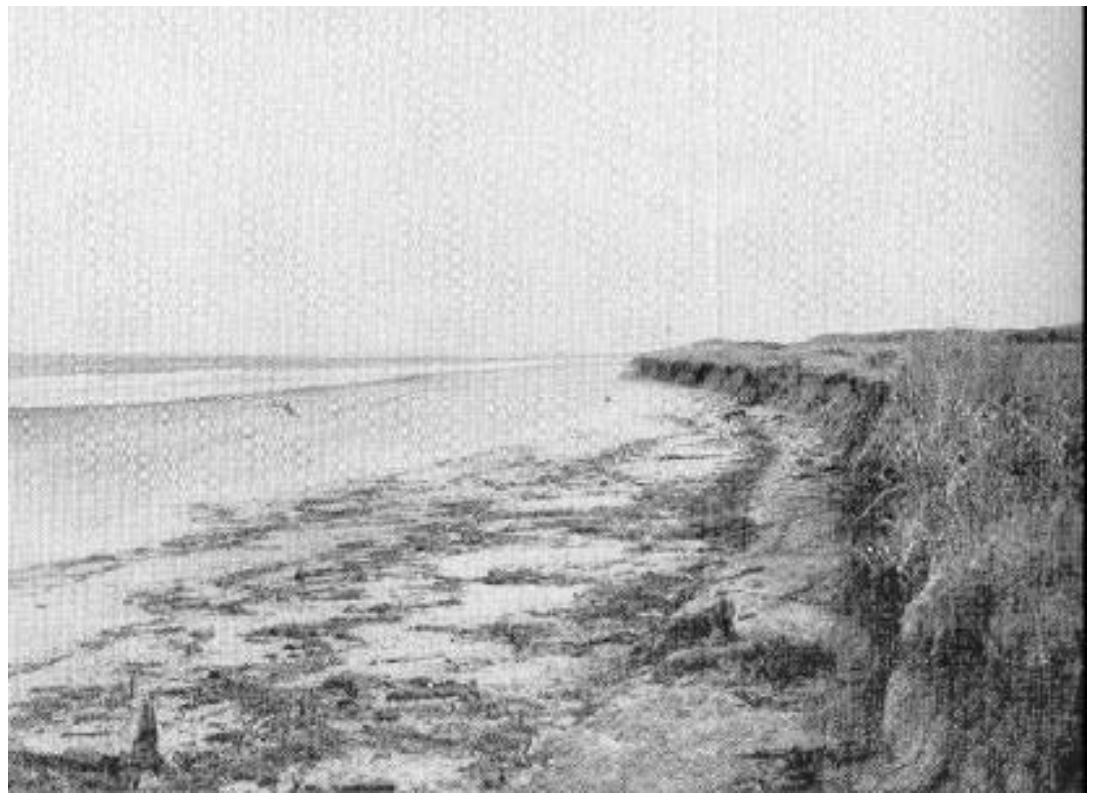

Fig. 129 - Quaternário recente. Cliff arenoso (nip) com planície em 3,50 m s.n.m. Praia do Sul - Paraná. 


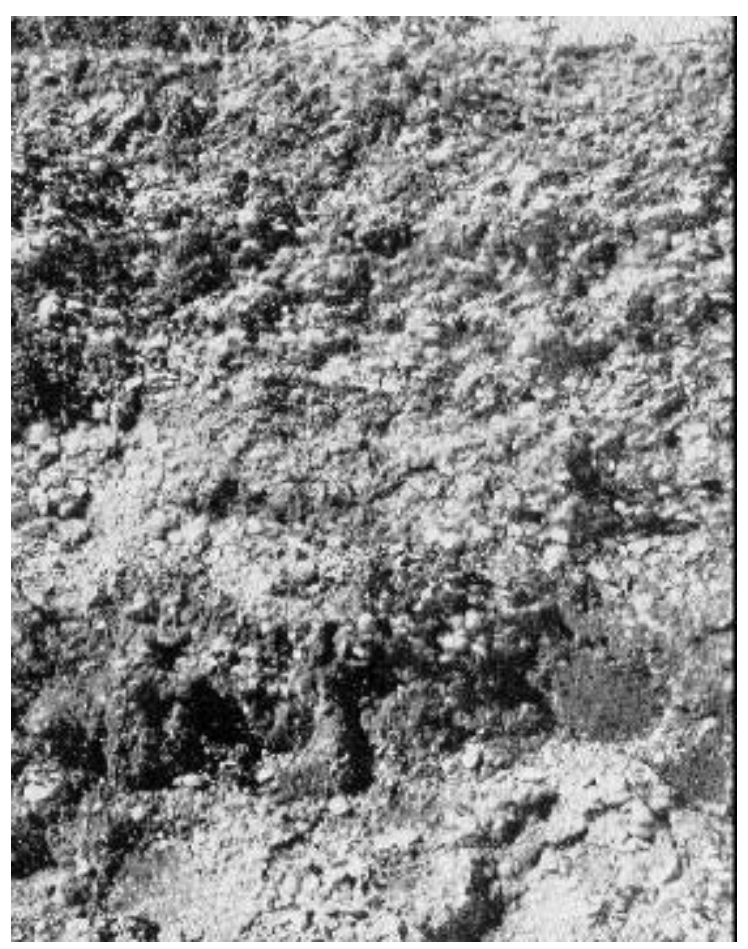

Fig. 130 - Quaternário recente. Corte do sambaqui de Matinhos para fins de pesquisas. Entre as conchas removidas predominam Anomalocardia brasiliana (berbigão), Lucina jamaicensis (ameijoa) e ostras. Zona litoral do Paraná.

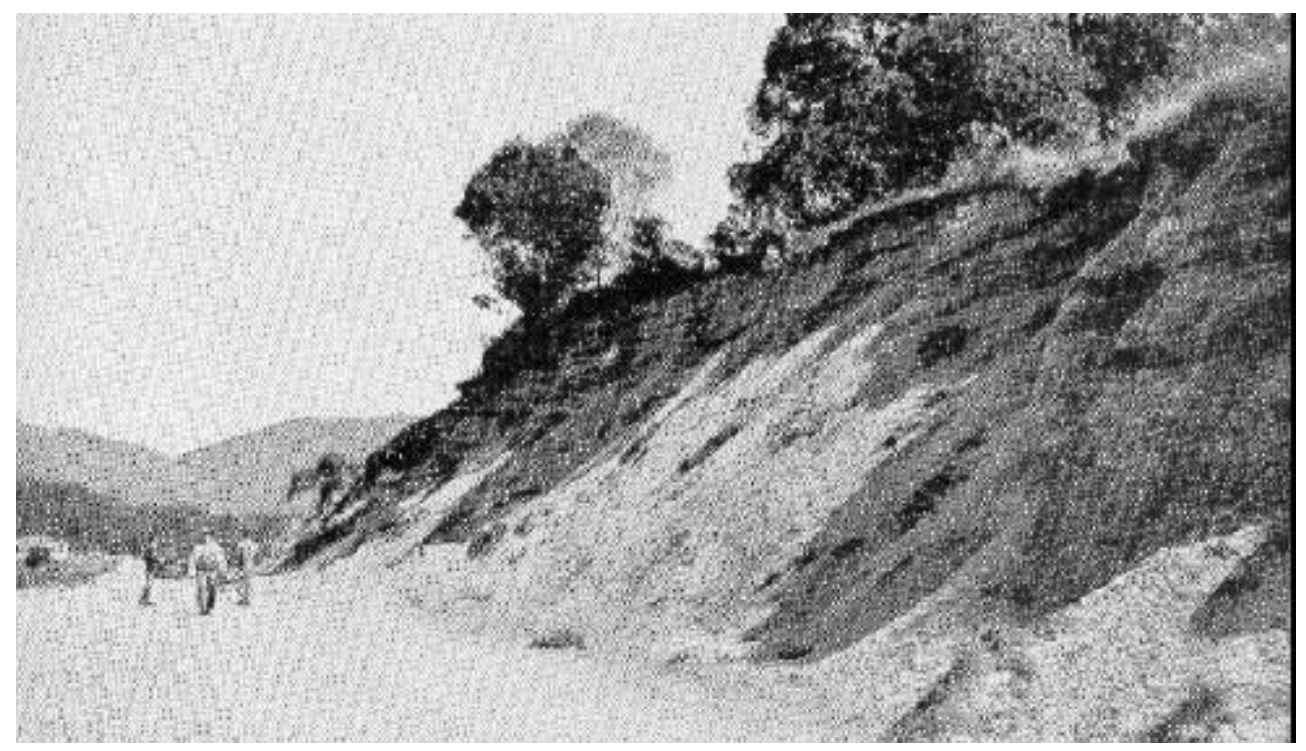

Fig. 131 - Quaternário recente. Sambaqui, ao noroeste de Imbituba, cortado na construção da estrada para Rio Una. Zona litoral de Santa Catarina. 


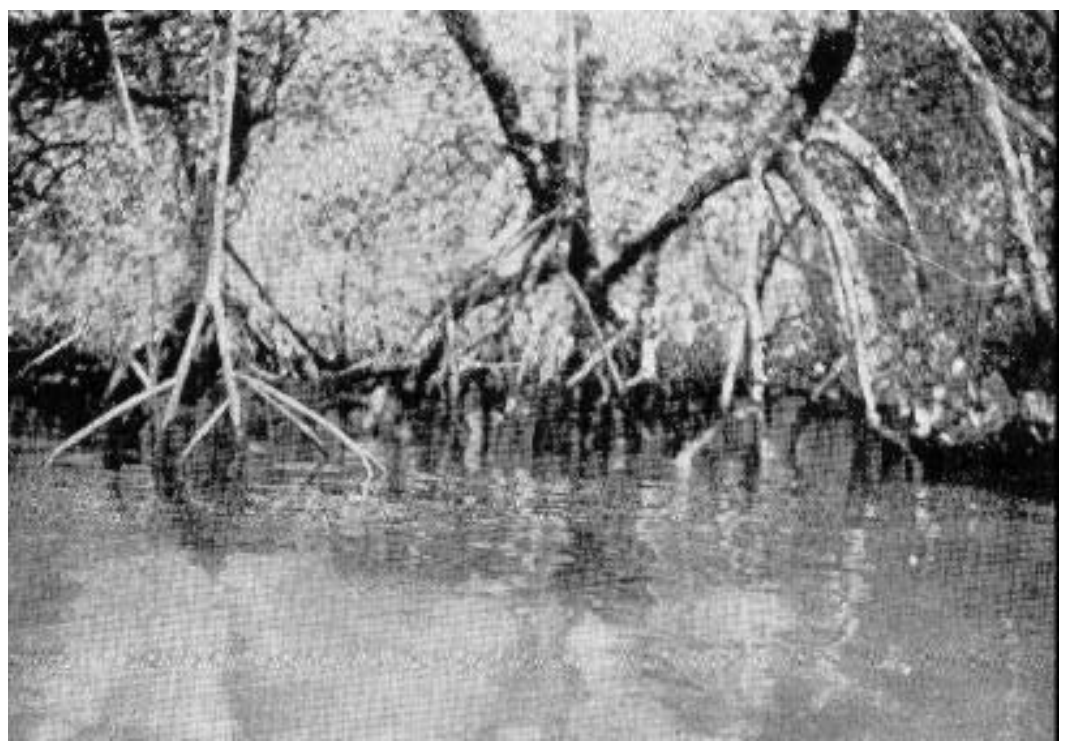

Fig. 132 - Quaternário recente. Raízes suportes do mangue (Rhizophora mangle) na baia de Guaratuba - Paraná.

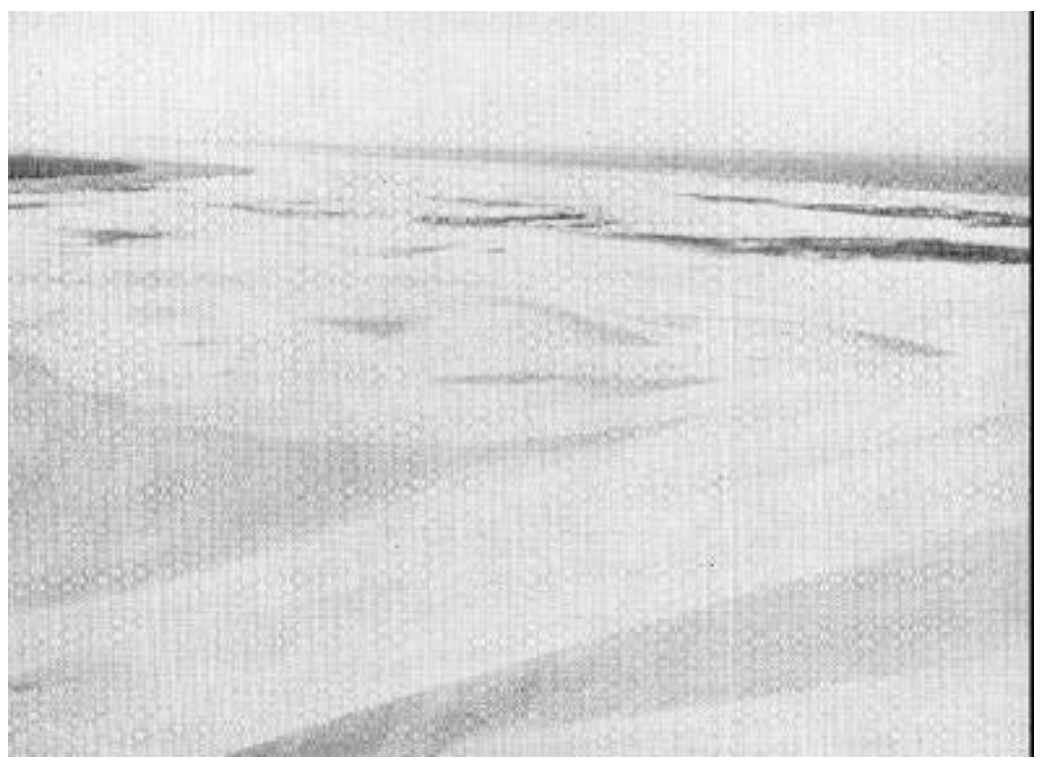

Fig. 133 - Quaternário recente. Um cordão litorâneo com dunas de areia movediça força o rio Araranguá a desviar paralelamente ao oceano, procurando a sua foz mais ao norte. Zona litoral de Santa Catarina. 


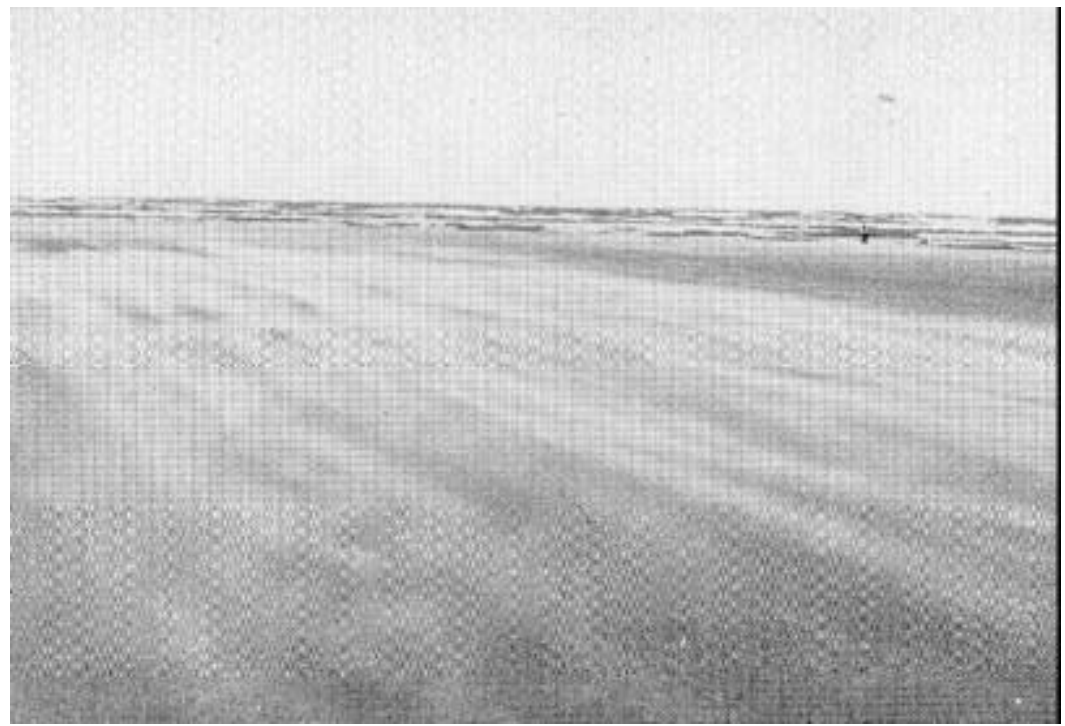

Fig. 134 - Quaternário recente. Areias movimentadas pelo vento nordeste na praia de Araranguá. As dunas apenas se formam quando as massas d'areia encontram obstáculos de rochas ou vegetação. Santa Catarina.

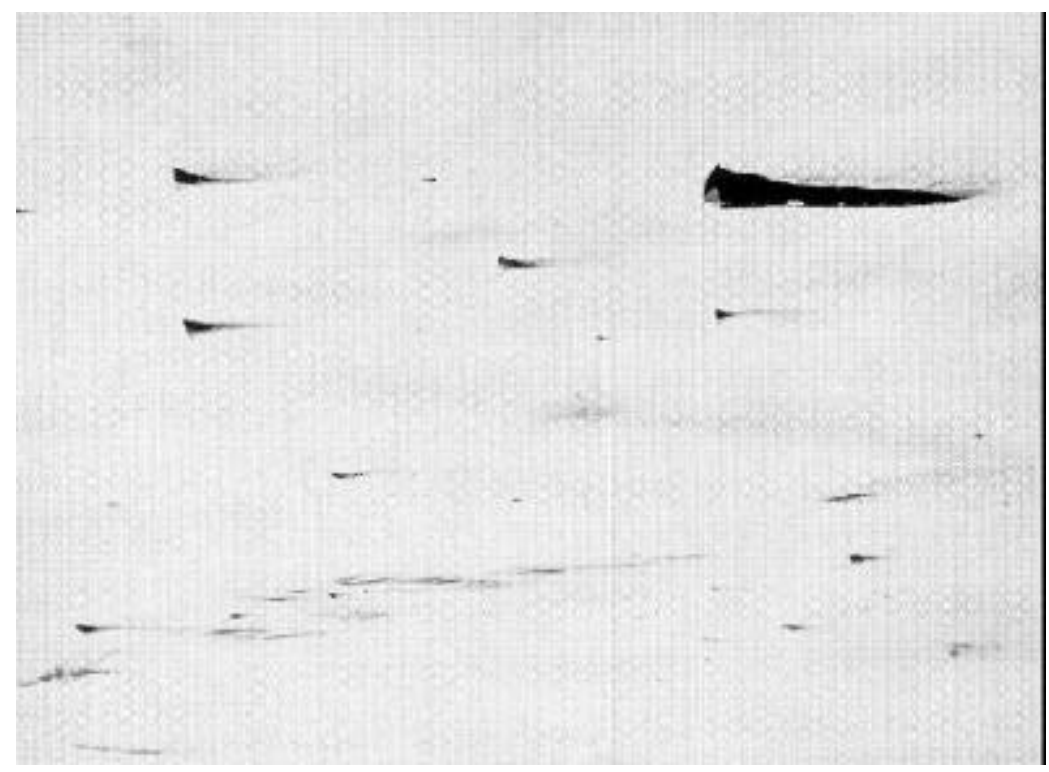

Fig. 135 - Quaternário recente. Resultado da ação do vento na praia de Araranguá. As valvas, cujas charneiras são voltadas contra o vento, protegem a areia, numa certa faixa, contra a deflação. Praia do Sul - Santa Catarina. 


\section{ANEXOS}

\section{I e II}

Brazilian Archives of Biology and Technology 
ANEXO I
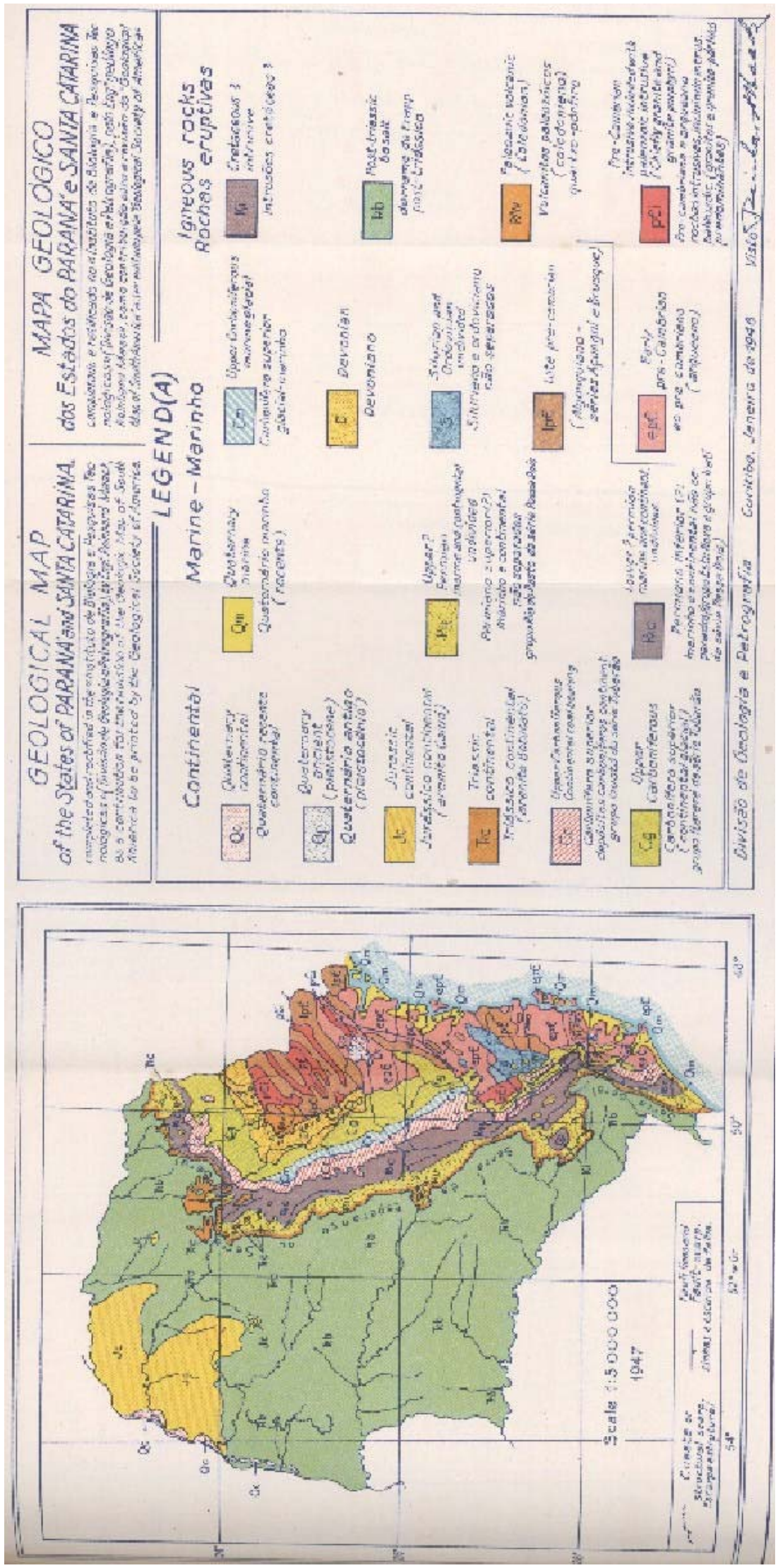
Maack, R.

ANEXO II

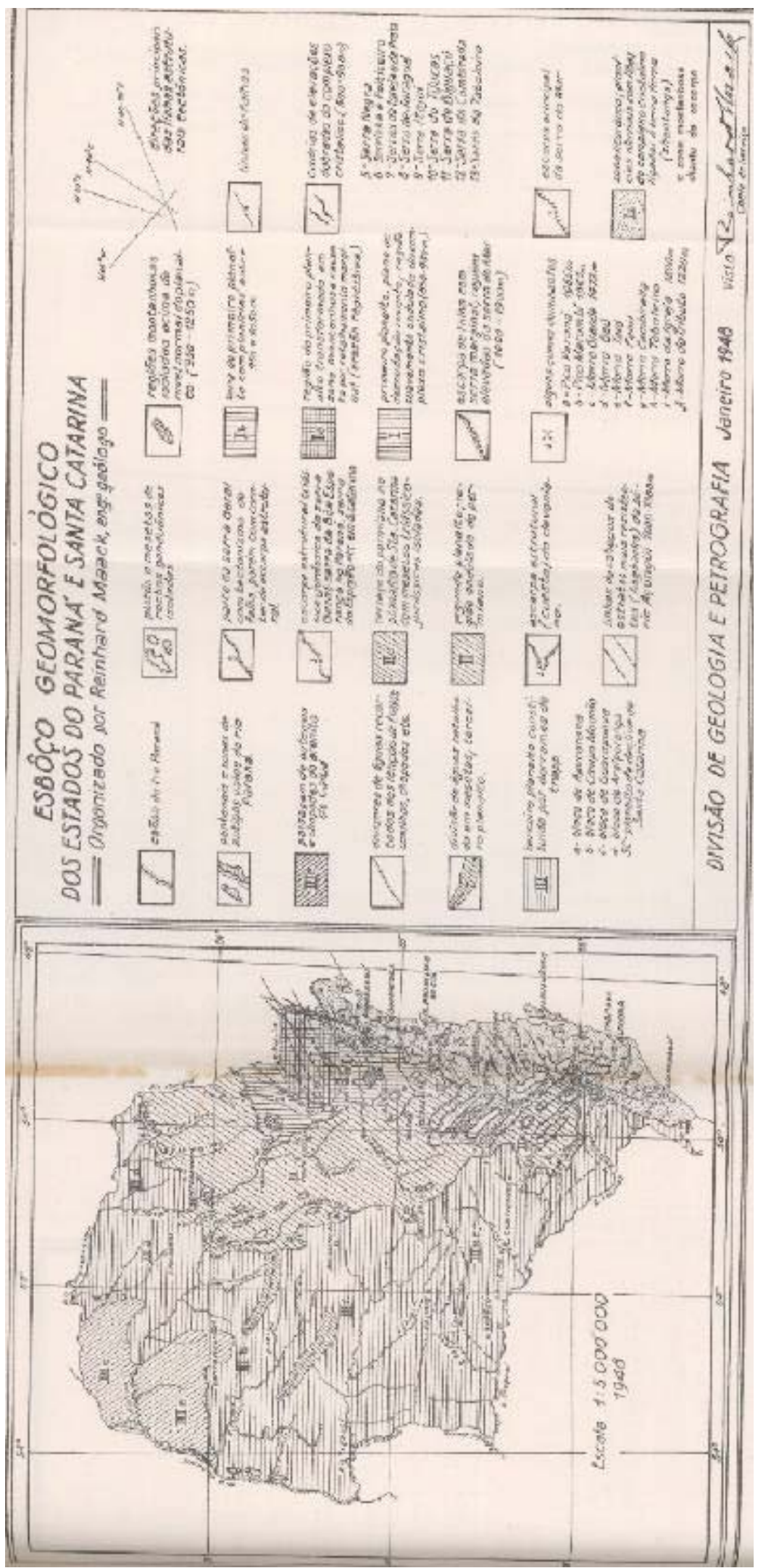

